\title{
Technical Support Document: 50\% Energy Savings Design Technology Packages for Highway Lodging Buildings
}

\author{
W Jiang \\ K Gowri \\ MD Lane \\ BA Thornton \\ MI Rosenberg \\ B Liu, Project Manager
}

September 2009

\section{Pacific Northwest}

NATIONAL LABORATORY

Proudly Operated by Battelle Since 1965 


\title{
DISCLAIMER
}

This report was prepared as an account of work sponsored by an agency of the United States Government. Neither the United States Government nor any agency thereof, nor Battelle Memorial Institute, nor any of their employees, makes any warranty, express or implied, or assumes any legal liability or responsibility for the accuracy, completeness, or usefulness of any information, apparatus, product, or process diselosed, or represents that its use would not infringe privately owned rights. Reference herein to any specific commercial product, process, or service by trade name, trademark, manufacturer, or otherwise does not necessarily constitute or imply its endorsement, recommendation, or favoring by the United States Government or any agency thereof, or Battelle Memorial Institute. The views and opinions of authors expressed herein do not necessarily state or reflect those of the United States Government or any agency thereof.

\author{
PACIFIC NORTHWEST NATIONAL LABORATORY \\ operated by \\ BATTELLE \\ for the \\ UNITED STATES DEPARTMENT OF ENERGY \\ under Contract DE-AC05-76RL01830 \\ Printed in the United States of America \\ Available to DOE and DOE contractors from the \\ Office of Scientific and Technical Information, \\ P.O. Box 62, Oak Ridge, TN 37831-0062; \\ ph: (865) 576-8401 \\ fax: (865) $576-5728$ \\ email: reports@adonis.osti.gov \\ Available to the public from the National Technical Information Service, \\ U.S. Department of Commerce, 5285 Port Royal Rd., Springfield, VA 22161 \\ ph: (800) 553-6847 \\ fax: (703) 605-6900 \\ email: orders@ntis.fedworld.gov \\ online ordering: http://www.ntis.gov/ordering.htm
}

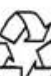

This document was printed on recycled paper. 


\title{
Technical Support Document: 50\% Energy Savings Design Technology Packages for Highway Lodging Buildings
}

\author{
W Jiang* \\ K Gowri \\ MD Lane** \\ BA Thornton \\ MI Rosenberg \\ B Liu, Project Manager
}

September 2009

Prepared for

the U.S. Department of Energy

under Contract DE-AC05-76RL01830

Pacific Northwest National Laboratory

Richland, Washington 99352

* Dr. Wei Jiang is a former employee of Pacific Northwest National Laboratory.

**Mr. Michael Lane works for Seattle Lighting Design Lab in Seattle, WA. 



\section{Executive Summary}

This Technical Support Document (TSD) describes the process, methodology and assumptions for development of the 50\% Energy Savings Design Technology Packages for Highway Lodging Buildings. This design guidance document provides specific recommendations for achieving 50\% energy savings in highway lodging properties over the energy-efficiency levels contained in ANSI/ASHRAE/IESNA Standard 90.1-2004 (ANSI/ASHRAE/IESNA 2004a). These 50\% savings design packages represent a further significant step towards realization of the U.S. Department of Energy's (DOE) net-zero energy building goal for new construction by the year 2025. DOE has previously supported the development of a series of $30 \%$ energy savings design guides, which were developed by a partnership of organizations, including the American Society of Heating, Refrigerating and Air-Conditioning Engineers, Inc. (ASHRAE), the American Institute of Architects (AIA), the Illuminating Engineering Society of North America (IESNA), the United States Green Buildings Council (USGBC), as well as DOE ${ }^{1}$.

This report provides recommendations and user-friendly design assistance to designers, developers, and owners of highway lodging properties and is intended to encourage steady progress towards net-zero energy performance in these buildings. The design package provides prescriptive recommendation packages that are capable of reaching the 50\% energy savings target for each climate zone, thereby easing the burden of the design and construction of highway lodging with exemplary energy performance.

To develop the set of energy efficiency measure recommendations that meet, or exceed, the $50 \%$ goal, we used a highway lodging prototype, adapted from previous work for achieving $30 \%$ savings in the Advanced Energy Design Guide for Highway Lodging Buildings (AEDG-HL), to represent this class of buildings.

We created baseline models from the prototype that are minimally code-compliant with ASHRAE 90.1-2004, and advanced models based on the recommended energy-efficient technologies. To determine the energy savings at different climate locations, we performed EnergyPlus simulation analyses. The simulation approach used is documented in this TSD, along with the characteristics of the prototype and assumptions of the baseline and advanced models.

Finally, we assessed the cost effectiveness of the energy-efficient technologies recommended in the design package using the simple payback period method.

Prescriptive packages of recommendations presented in the design package by climate zone include enhanced envelope technologies, interior and exterior lighting technologies, heating, ventilating, and airconditioning (HVAC) and service water heating (SWH) technologies, and miscellaneous appliance technologies. Final energy efficiency recommendations for each climate zone are included, along with the results of the energy simulations indicating a national-weighted average energy savings over all buildings and climates of 55.5\% in comparison with the Standard 90.1-2004 as baseline.

A cost estimate of the recommended energy efficiency measures is provided to evaluate costeffectiveness relative to the energy savings. The evaluated design package has a simple payback that ranges from about 9.5 to 16 years, with an average of a little over 11 years.

\footnotetext{
${ }^{1}$ The published AEDG guides are available for free download at http://www.ashrae.org/technology/page/938
} 


\section{Acknowledgments}

This document was prepared by Pacific Northwest National Laboratory (PNNL) for the U.S. Department of Energy's Building Technologies (BT) Program. The authors would like to thank Dr. Dru Crawley, Team Leader of BTP's Commercial Buildings Integration R\&D, for his dedicated support to and thoughtful guidance of this project.

The authors would like to thank all the external peer reviewers for their tremendous volunteer efforts and insightful reviews of our energy analysis work during the development of this report. Without their expertise in reviewing the energy efficiency measures covering envelope, lighting, HAVC systems, and service water heating systems, this document would be considerably less rigorous. The following experts peer reviewed an earlier draft of this report:

Erin McConahey, Principal, ARUP

Floyd Barwig, Director, Office of Energy Efficiency and Environment, New York State Public Service Commission

Glenn Hansen, Project Manager, Portland Energy Conservation Incorporated

Kent Peterson, President, P2S Engineering

Dr. Merle McBride, Owens Corning Science and Technology Center

Michael Lane, Project Manager, Seattle Lighting Design Lab

Oliver Baumann, President, Ebert \& Bauman Consulting Engineers, Inc.

Last, but not least, the authors would like to specially recognize Andrew Nicholls, the program manager overseeing the Commercial Building Integration Program at PNNL, for his strong support of this particular project. The authors greatly appreciate the assistance of Todd Taylor at PNNL. Todd constructed the cluster simulation structure in EnergyPlus, which allowed us to evaluate the many variations of energy efficiency technologies in a timely fashion to meet the project's compressed schedule. Finally, Weimin Wang at PNNL provided very insightful support on energy modeling strategy using EnergyPlus and Jian Zhang at PNNL provided a detailed technical review of this report.

This project was a true team effort and the authors would like to express their deep appreciation to everyone who contributed to the completion of this work.

Bing Liu

Project Manager

Pacific Northwest National Laboratory 


\section{Acronyms and Abbreviations}

AEDG

AEDG-HL

AEDG-SO

AEDG-SR

AEDG-WHS

AFUE

AHLA

AIA

AHRI

ASHRAE

BHP

CBECS

CDD

CEC

CEE

CFL

cfm

c.i.

COP

CPU

DOE

DX

$\mathrm{E}_{\mathrm{c}}$

EEM

EER

EIA

EPDM

ERV

$\mathrm{E}_{\mathrm{t}}$

GFX

gpm

HDD

HIR

HSPF

HVAC

IECC
Advanced Energy Design Guide

Advanced Energy Design Guide for Highway Lodging Buildings

Advanced Energy Design Guide for Small Office Buildings

Advanced Energy Design Guide for Small Retail Buildings

Advanced Energy Design Guide for Warehouses and Self-Storage Buildings

annual fuel utilization efficiencies

American Hotel \& Lodging Association

American Institute of Architects

Air-Conditioning, Heating, and Refrigeration Institute

American Society of Heating, Refrigerating and Air Conditioning Engineers, Inc.

break horsepower

Commercial Building Energy Consumption Survey

Cooling degree day

California Energy Commission

Consortium for Energy Efficiency

compact fluorescent

cubic feet per minute

continuous insulation

coefficient of performance

Central Processing Unit

U.S. Department of Energy

direct expansion

combustion efficiency

energy efficiency measure

energy efficiency ratio

Energy Information Administration

ethylene-propylene-diene-terpolymer membrane

energy recovery ventilator

thermal efficiency

gravity-film-heat exchanger

gallon per minute

heating degree day

heat input ratio

heating season performance factors

heating, ventilation and air conditioning

International Energy Conservation Code 
IESNA

in.

LBNL

LCD

LEED $^{\circledR 2}$

LMTD

LPD

MAU

MSRP

NBI

$\mathrm{NC}^{3}$

NEA

NR

NREL

NZEB

OA

PG\&E

PIR

PNNL

PTAC

PTHP

Q

RPM

RE

SEER

SHGC

SL

SRI

SSPC

SWH

TSD

UA

USGBC

VLT

w.c.

WSHP

WWR
Illuminating Engineering Society of North America

inch

Lawrence Berkeley National Laboratory

liquid crystal display

Leadership in Energy and Environment Design

logarithmic mean temperature difference

lighting power densities

make-up air unit

manufacturer suggested retail price

New Building Institute

National Commercial Construction Characteristics Database

National Energy Alliance

no requirement

National Renewable Energy Laboratory

net-zero energy buildings

outdoor air

Pacific Gas and Electric Company

passive infrared

Pacific Northwest National Laboratory

packaged terminal air conditioner

packaged terminal heat pump

rated input power

revolutions per minute

recovery efficiency

seasonal energy efficiency ratio

solar heat gain coefficient

standby heat loss

solar reflectance index

Standing Standard Project Committee

service water heating

technical support document

standby heat loss coefficient

U.S. Green Building Council

visible light transmittance

water column

water-source heat pump

window-to-wall ratio

${ }^{2}$ LEED is a registered trademark of the U.S. Green Building Council 


\section{Contents}

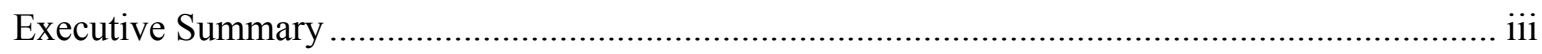

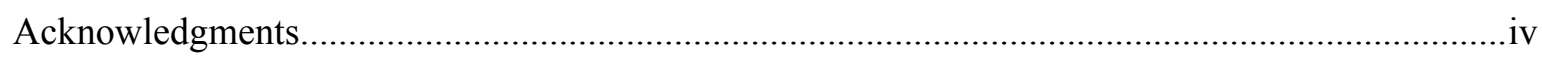

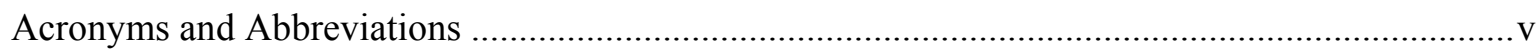

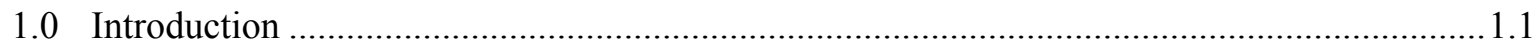

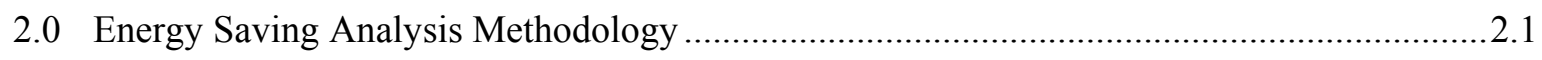

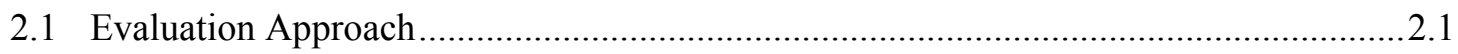

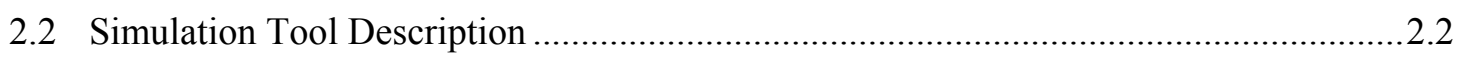

2.3 Climate Zones and Construction Weights.................................................................

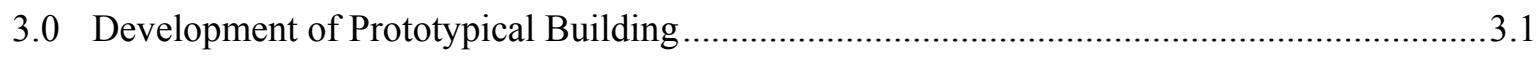

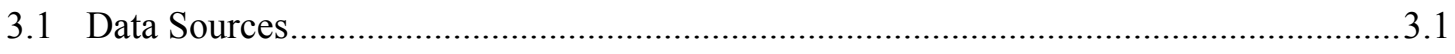

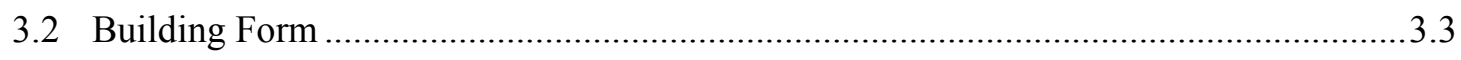

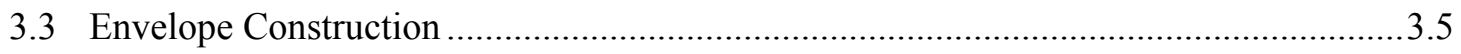

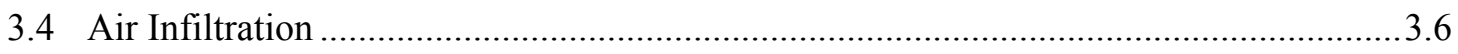

4.0 Development of Baseline Building Model and Assumptions..............................................4.1

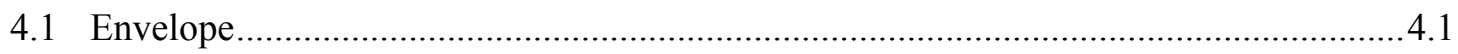

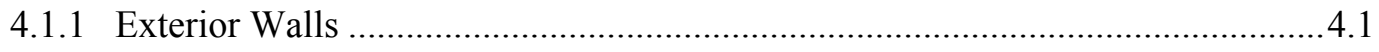

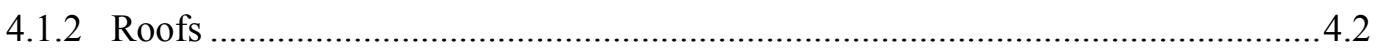

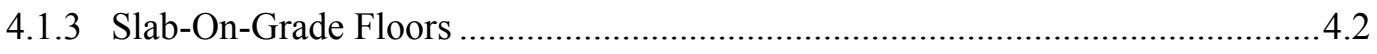

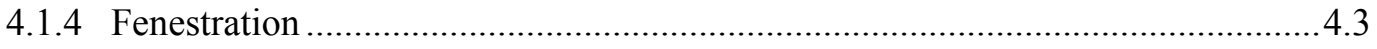

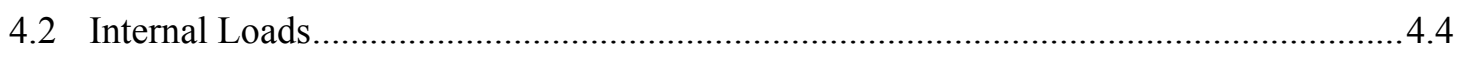

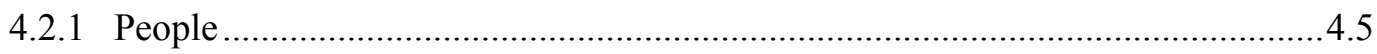

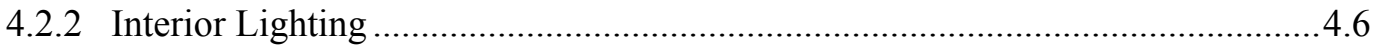

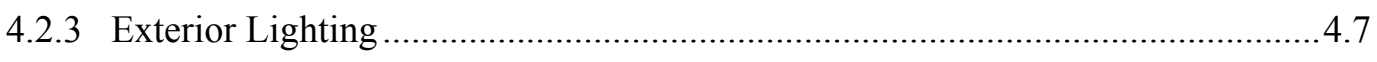

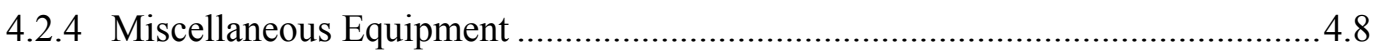

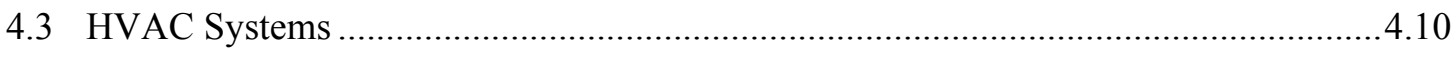

4.3.1 HVAC System Type........................................................................... 4.10

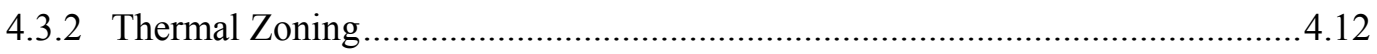

4.3.3 Building HVAC Operating Schedules ...........................................................15

4.3.4 Heating and Cooling Thermostat Setpoint ..................................................... 4.15

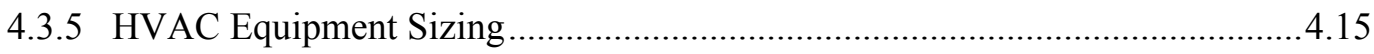

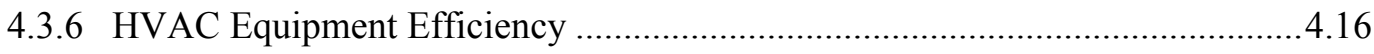

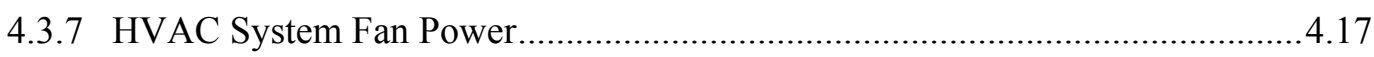

4.3.8 Ventilation Rates and Schedules ................................................................... 4.19

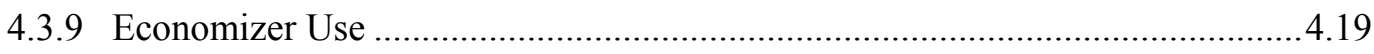

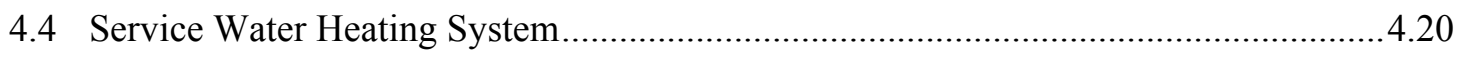

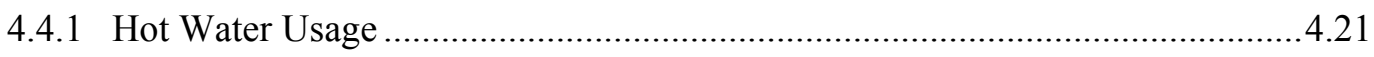




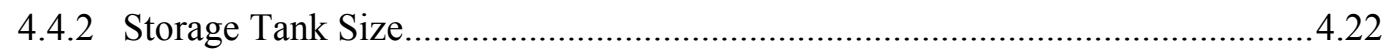

4.4.3 Rated Input Power and Standby Heat Loss Coefficient ....................................4.22

4.4.4 Water Heater Thermal Efficiency ...................................................................4.23

5.0 Development of Advanced Building Model and Assumptions .............................................5.1

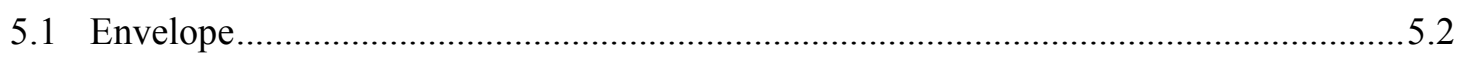

5.1.1 Enhanced Insulation for Opaque Assemblies .................................................5.2

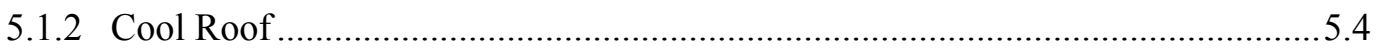

5.1.3 High Performance Windows ........................................................................... 5.4

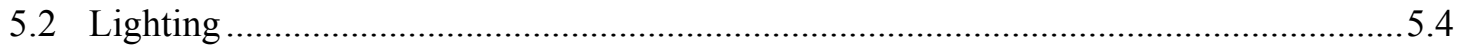

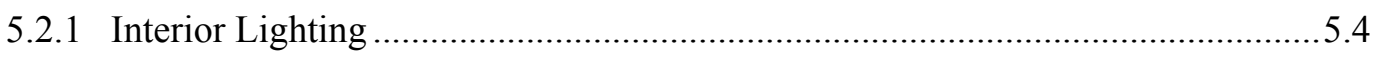

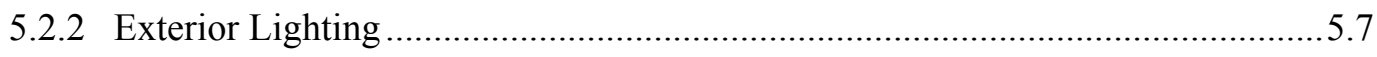

5.2.3 Miscellaneous Equipment …......................................................................... 5.9

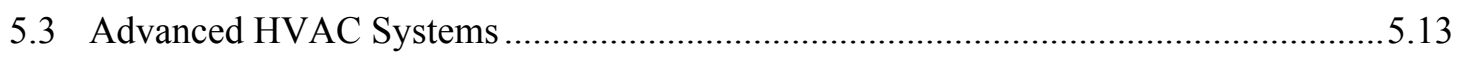

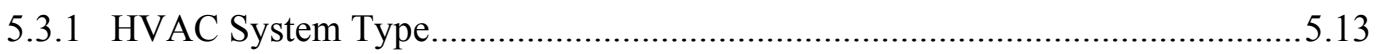

5.3.2 High Efficiency HVAC Equipment …….......................................................5.14

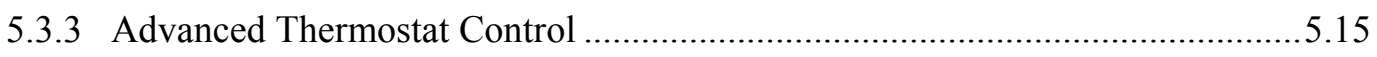

5.3.4 Lower Static Pressure Ductwork .......................................................................... 5.16

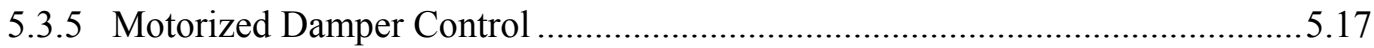

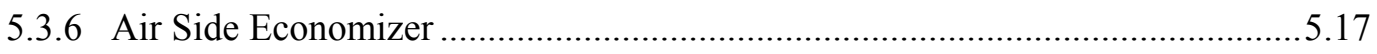

5.3.7 Energy Recovery Ventilator....................................................................... 5.17

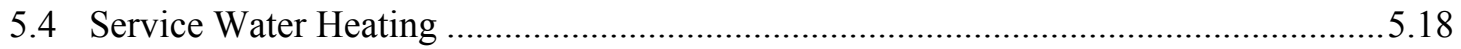

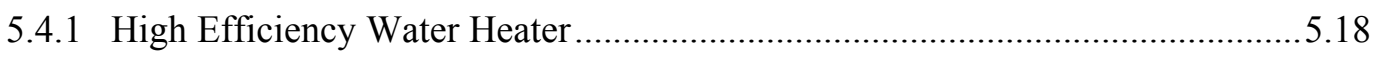

5.4.2 Hot Water Usage Reduction....................................................................... 5.18

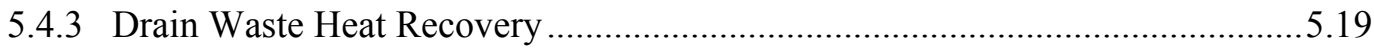

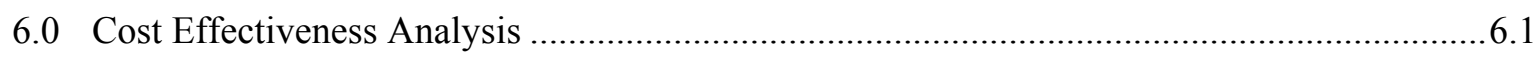

6.1 Basis for Incremental Energy Savings Measure Costs ................................................. 6.1

6.2 Comparison of Incremental Costs to Baseline Costs for Construction ...........................6.3

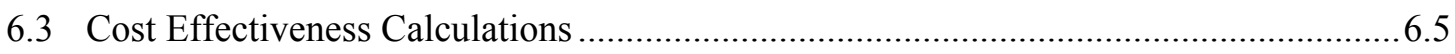

6.4 A Perspective on Costs for Advanced Buildings ....................................................6.6

7.0 Recommendations and Energy Savings Results ................................................................. 7.1

7.1 Final Energy Savings Recommendations.................................................................. 7.1

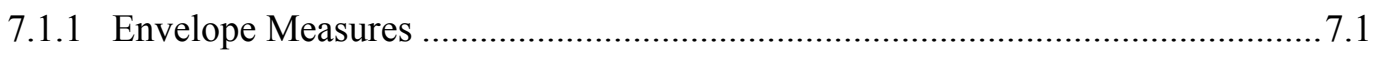

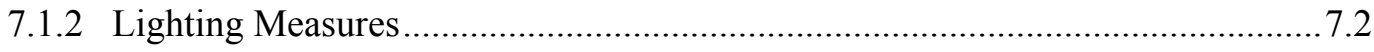

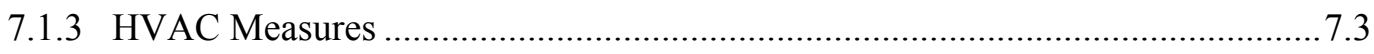

7.1.4 Service Water Heating Measures ...................................................................... 7.4

7.1.5 Miscellaneous Appliances Measures................................................................ 7.5

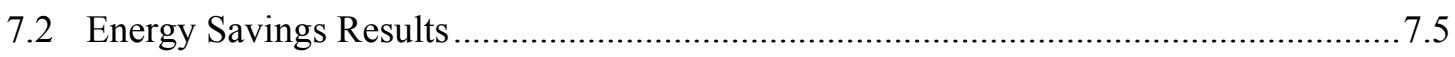

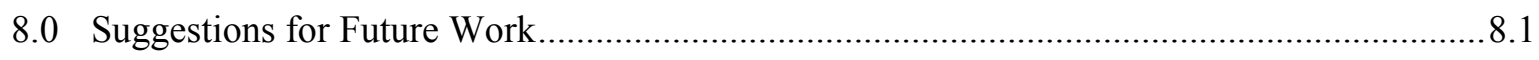

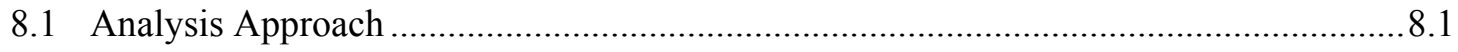


8.2 Adjustments to Prototypes and Energy Modeling......................................................... 8.1

8.3 Advanced Building - Additional Potential Energy Measures....................................... 8.2

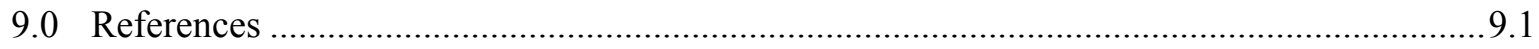

Appendix A Building Energy Modeling Schedules................................................................ A.1

Appendix B Building Prototypes Model Assumptions ............................................................. B. 1

Appendix C Baseline and Advanced Buildings Model Assumptions.............................................

Appendix D EnergyPlus Water-to-Air Cooling Coil and Heating Coil Performance Model

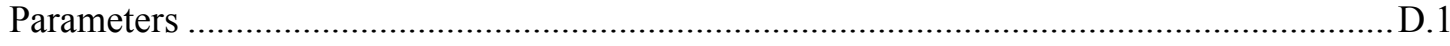




\section{Figures}

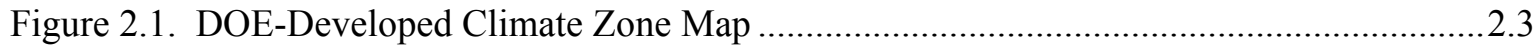

Figure 3.1. Hampton Inn Prototype Ground Floor Plan................................................................... 3.2

Figure 3.2. Hampton Inn Prototype Typical Floor Plan.............................................................

Figure 3.3. Building Shape Distribution in 2003 CBECS (for motels/hotels with less than 80

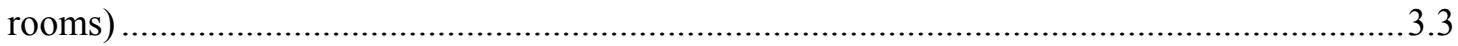

Figure 3.4. Hotel/Motel Building Number vs. Floor Area Distribution from F.W. Dodge Database

Figure 3.5. Axonometric View and Floor Plans of the $43,000 \mathrm{ft}^{2}\left(3,995 \mathrm{~m}^{2}\right)$ Highway Lodging Prototype

Figure 3.6. WWR Distribution for Motel/Hotel Buildings with Less than 80 Rooms in 2003 CBECS

Figure 4.1. Highway Lodging Guestroom Typical Weekday Schedules .

Figure 4.2. Main Heating Equipment Categories in 2003 CBECS (for motel/hotels with less than 80 rooms)

Figure 4.3. Main Cooling Equipment Categories in 2003 CBECS (for motel/hotels with less than 80 rooms)

Figure 4.4. HVAC Zoning Map - First Floor ..................................................................... 4.13

Figure 4.5. HVAC Zoning Map - Typical Floor

Figure 4.6. Water Heating Equipment Categories in 2003 CBECS (for motel/hotels with less than 80 rooms)

Figure 5.1. Guest Room Interior Lighting Schedule .................................................................

Figure 5.2. Guest Room Plug Loads Schedule ........................................................................ 5.12

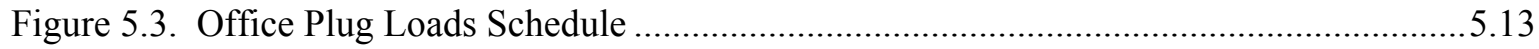

Figure 7.1. Percentage of the Site Energy Savings .................................................................. 7.6

Figure 7.2. Site Energy Savings by End Use Category Relative to 90.1-2004 Baseline ................7.8 


\section{Tables}

Table 2.1. Construction Volume Weights for All ASHRAE Building Prototypes and Climate Zones. .2 .5

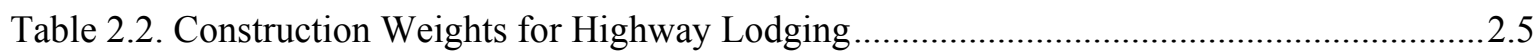

Table 3.1. Highway Lodging Prototype Space Type ...................................................................

Table 4.1. Fenestration U-Factor and SHGC Value for the Baseline Model.................................4.4

Table 4.2. Peak Occupancy Density by Space Type.................................................................... 4.6

Table 4.3. Baseline Interior Lighting Power Density by Space Type..........................................4.7

Table 4.4. Baseline Exterior Lighting Power........................................................................... 4.7

Table 4.5. Baseline Plug Load Peak Power Density by Space Type .......................................... 4.8

Table 4.6. Baseline Plug Load Density Calculations for Guest Rooms.........................................4.9

Table 4.7. Baseline Laundry Equipment Gas Consumption .....................................................10

Table 4.8. Baseline Building HVAC Systems .......................................................................... 4.12

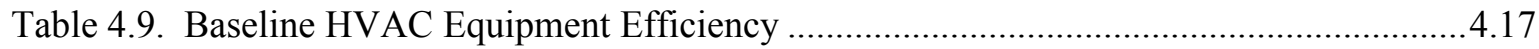

Table 4.10. Total Fan Static Pressure Drops Calculations for Baseline MAU System ................4.18

Table 4.11. Minimum Outside Air Requirement by Space Type .............................................4.19

Table 4.12. Economizer Requirements in Standard 90.1-2004 ..................................................20

Table 5.1. Insulation Requirements Comparison for Roofs with Insulation Entirely Above Deck 5.2

Table 5.2. Insulation Requirements Comparison for Above-Grade Mass Walls...........................5.3

Table 5.3. Insulation Requirements Comparison for Slab-on-Grade Floor ...................................5.3

Table 5.4. Fenestration U-factor and SHGU Values Comparison .............................................5.5

Table 5.5. Interior Lighting Power Density by Space Type Comparison .....................................5.6

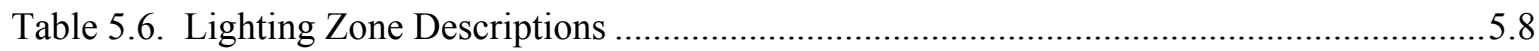

Table 5.7. Exterior Lighting Power Densities in the Advanced Models.......................................5.8

Table 5.8. Advanced Exterior Lighting Power ............................................................................5.9

Table 5.9. Plug Load Density Calculations for Guest Rooms in the Advanced Models ..............5.10

Table 5.10. Plug Load Peak Power Density by Space Type in the Advanced Models.................5.10

Table 5.11. Laundry Equipment Hot Water and Energy Use Comparison..................................5.11

Table 5.12. Estimated Energy Use Reduction in Plug Loads with Controls ...............................5.13

Table 5.13. Building HVAC Systems Comparison .................................................................14

Table 5.14. Advanced HVAC Equipment Efficiency ..............................................................15

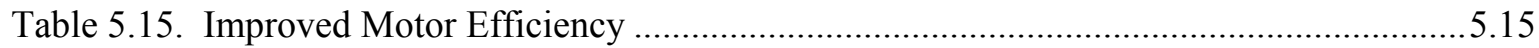

Table 5.16. Total Fan Static Pressure Drops Calculations for the Advanced MAU System ........5.16

Table 5.17. Gravity-Film-Heat-Exchanger Performance Data for Model PS4-60 and Model G3-

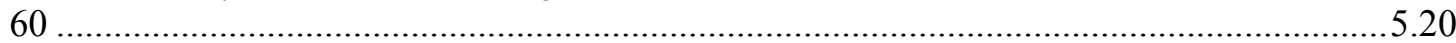

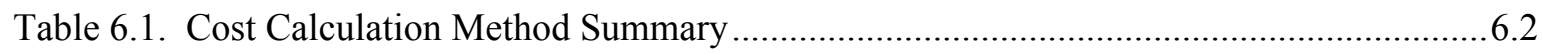

Table 6.2. Incremental Costs for Advanced Energy Measures ....................................................6.4

Table 6.3. Unit Cost Increase ................................................................................................. 6.5 
Table 6.4. Simple Payback Period ....................................................................................... 6.6

Table 7.1. Final Energy Savings Recommendations - Building Envelope ................................. 7.2

Table 7.2. Final Energy Savings Recommendations - Lighting............................................... 7.3

Table 7.3. Final Energy Savings Recommendations - HVAC ................................................... 7.4

Table 7.4. Final Energy Savings Recommendations - Service Water Heating .............................7.4

Table 7.5. Final Energy Savings Recommendations - Miscellaneous Appliances ........................7.5

Table 7.6. Energy Savings Results by End Use ....................................................................... 7.9 


\subsection{Introduction}

Buildings account for over $40 \%$ of total energy use and over $70 \%$ of electricity use in the United States. To tackle this challenge, the Department of Energy (DOE) has, through its Building Technologies Program, established a strategic goal to "create technologies and design approaches that enable netzero energy buildings (NZEB) at low incremental cost by 2025”.

To reach NZEB by 2025, DOE BT has implemented a strategy to develop information packages and tools to support realization of $30 \%, 50 \%$ and $70 \%$ better buildings, relative to ANSI/ASHRAE/ IESNA Standard 90.1-2004 (ANSI/ASHRAE/IESNA 2004a). Beginning in FY2004, DOE has provided financial and technical support for the development the Advanced Energy Design Guides and Technical Support Documents in conjunction with these partnering organizations: the American Society of Heating, Refrigerating and Air Conditioning Engineers (ASHRAE), the American Institute of Architects (AIA), the Illuminating Engineering Society of North America (IES), and the U.S. Green Building Council $(\mathrm{USGBC})^{1}$.

There are two distinct but related products under this element. An Advanced Energy Design Guide (AEDG) is a publication targeted at architects and other practitioners that provides specific guidance on how to achieve certain levels of high energy performance in buildings. A Technical Support Document $(T S D)$ is a background document describing the assumptions and methodologies used to achieve particular levels of energy performance. AEDGs invariably have concomitant TSDs (to document the rationale behind the design decisions), but not all TSDs are necessarily associated with AEDGs.

ASHRAE and its partners have, to date, published five design guides focused on new construction in small commercial buildings. Building types covered include small office, small retail, K-12 school, small warehouse and self-storage, and highway lodging ${ }^{2}$. The purpose of these Guides is to provide recommendations for achieving at least 30\% energy savings over the minimum code requirements of ASHRAE Standard 90.1-1999 (ANSI/ASHRAE/IESNA 1999). The sixth and final Guide in this 30\% series for small healthcare facilities will be published in FY2010.

The $30 \%$ energy savings target is the first step toward achieving net-zero commercial buildings. Having proven the feasibility of $30 \%$ energy savings across a variety of building types, DOE now exits the $30 \%$ design guide area and focuses on the informational products to realize $50 \%$ and $70 \%$ wholebuilding energy savings levels across a variety of climate zones, building types, energy intensities and sizes. The purpose of this Technical Support Document, or TSD, is to provide a design technology package that indicates, measure by measure, how to achieve 50\% energy savings relative to Standard 90.1-2004 for highway lodging buildings.

Prior to this TSD, the initial 30\% series Guides were developed by a project committee administered under ASHRAE's Special Project procedures. The AEDG project committee included membership from each of the partner organizations. Two of DOE's national laboratories, Pacific Northwest National Laboratory (PNNL) and National Renewable Energy Laboratory (NREL), have provided leadership and

\footnotetext{
${ }^{1}$ The published AEDG guides are available for free download at http://www.ashrae.org/technology/page/938

${ }^{2}$ In addition, the New Buildings Institute participated in the development of the AEDG for Small Office Buildings.
} 
energy analysis support to the various AEDG project committees in the past. Proceeding to the 50\% guides, DOE decided to develop the TSDs first to greatly expedite the speed at which the final guides are provided by ASHRAE to the market to impact actual design decisions in new commercial buildings. These 50\% TSDs do not necessarily support ASHRAE-published AEDGs, but are intended to be standalone reports documenting the technical feasibility of achieving a 50\% reduction in whole-building energy use. These reports are intended to demonstrate that exemplary energy performance is feasible today with available technology.

In FY2009, PNNL focused on two building types to analyze 50\% energy savings performance: highway lodging (this report) and medium office (published as a sister report) for three reasons. First, these subsectors use a significant amount of energy and therefore represent significant opportunities for significant energy savings potential. Second, DOE has launched three commercial building energy alliances (CBAs) that include both lodging and offices. Because the goal of the CBEAs is ultimately to realize 50\% energy savings in new construction, the TSDs will directly support this effort to realize energy efficiency at scale through national account replication. Finally, PNNL possesses technical expertise in both areas, as evidenced by the previous development of the $30 \%$ AEDG for Small Offices and Highway Lodging.

Publication and use of these two design technology packages for office and lodging will lead to additional energy efficient design improvements well beyond code in our nation's new office and motels and will thus significantly contribute to BT's net-zero energy building goal in 2025 . For reference, office and lodging are ranked as the first and fourth largest in terms of primary energy consumption in the commercial building sector, respectively, if all size categories are included. The combination of the office and lodging sectors constitutes $26 \%$ of the primary energy consumption in existing commercial buildings and represents $24 \%$ of the total square footage in the commercial building stock. ${ }^{3}$ The design technology packages will provide a sensible, hands-on approach to design through the use of "off-the-shelf" technologies and products that are practical and commercially available from major manufacturers.

\footnotetext{
${ }^{3} 2008$ Buildings Energy Data Book, U.S. Department of Energy, Table 3.2.2 http://buildingsdatabook.eren.doe.gov/docs/xls_pdf/3.2.2.pdf
} 


\subsection{Energy Saving Analysis Methodology}

This section describes the energy savings evaluation approach, simulation tools, and climate locations that were used to assess and quantify the 50\% energy savings over ASHRAE Standard 90.1-2004 (ANSI/ASHRAE/IESNA 2004a) by implementing the energy efficiency measures recommended by the design package.

\subsection{Evaluation Approach}

The evaluation approach was similar to the one used for the Advanced Energy Design Guides (AEDGs), where prototypical buildings were devised, and then simulated in various climate locations covering the eight climate zones contained in ASHRAE Standard 90.1 and the International Energy Conservation Code (IECC) (IECC 2006). Earlier guides used 15 cities to represent the climate zones (Jarnagin et al. 2006; Liu et al. 2006; Liu et al. 2007; Pless et al. 2007; Jiang et al. 2008). This study uses 16 cities selected by DOE in establishing a new set of benchmark buildings. The analysis results established that the energy efficiency measure (EEM) recommendations in the design package to meet the $50 \%$ energy savings target.

Following a consistent methodology for the AEDGs, the energy savings goal of the design package is based on site energy savings between minimally code-compliant (baseline) highway lodging buildings and advanced highway lodging buildings that use the recommendations in the design package. Different from the AEDGs, where the baseline level energy use was set for the buildings in compliance with the ASHRAE Standard 90.1-1999, the baseline buildings in this design package are based on the requirements of ASHRAE Standard 90.1-2004. The selection of ASHRAE 90.1-2004 for the baseline was also because the standard was the most recent for which DOE had issued a formal determination of energy savings.

Historically, energy savings have been expressed in two ways: for regulated loads only and for all loads (the whole building). Regulated loads metrics do not include plug and process loads that are not code regulated. Whole-building energy savings, on the other hand, include all loads (regulated and unregulated) in the calculations. In general, whole-building savings are more challenging than regulated loads savings given the same numerical target, but more accurately represent the impact of the building on the national energy system. Among the AEDGs, Energy Design Guide for Small Office Buildings (AEDG-SO) (ASHRAE 2004), Advanced Energy Design Guide for Small Retail Buildings (AEDG-SR) (ASHRAE 2006) and Advanced Energy Design Guide for Warehouses and Self-Storage Buildings (AEDG-WHS) (ASHRAE 2008) evaluated the energy savings based on regulated load metrics and did not include any EEMs for plug loads. Considering that plug loads consume significant energy in lodging buildings, the project committee responsible for the development of Advanced Energy Design Guide for Highway Lodging (AEDG-HL) (ASHRAE 2009) provided recommendations on plug loads and the energy savings target was evaluated based on whole-building energy use metrics. Consistent with the AEDG-HL, the whole-building energy savings metrics are used in this design package to assess the 50\% energy savings target. This method is also in line with the current ASHRAE and LEED practices specified in Appendix G of ASHRAE 90.1-2004 and in LEED ${ }^{\circledR}$ rating systems (USGBC 2009).

The purpose of this building energy simulation analysis is to assess and quantify the energy savings potential of the design package's final recommendations. A series of steps was taken to reach this goal. 
- Develop highway lodging prototypical buildings. The building prototype used for this analysis is the $43,000 \mathrm{ft}^{2}$ highway lodging prototype, one of the two prototypes, developed during the development of the AEDG-HL. Therefore, many of the assumptions originated during the AEDG-HL work. This $43,000 \mathrm{ft}^{2}$ highway lodging prototype was also adopted by DOE as the DOE's commercial building benchmark model for small hotel (DOE 2009). Section 3.0 in this report describes the development of the prototype in details.

- Create baseline models from the prototype that are minimally code-compliant for ASHRAE 90.12004. Section 4.0 documents the model inputs assumptions for the baseline models.

- Create advanced models based on the recommended energy-efficient technologies in the design package. At the beginning of the technology selection, technologies were selected from the EEMs recommended in the AEDG-HL, and generally reflected technologies in fairly common use. Sensitivities to the use of these technologies were assessed, where various technologies are considered in combination to assess the ease with which the energy savings target might be reached. Section 5.0 documents the model inputs assumptions for the advanced models.

- Assess cost effectiveness of the recommend energy-efficient technologies in the design package. Section 6.0 in the report provides the incremental cost of the EEMs and estimates the simple payback periods in each climate city when implementing the recommendations in this TSD.

- Evaluate 50\% energy savings in all 16 representative climate cities. Sixteen climate locations (cities) were selected to adequately represent the 8 climate zones in the United States. Climate zone-specific recommendations were validated by running baseline and advanced models at each of the locations. The summary of energy simulation results for all locations and the final energy saving recommendations by climate zones are described in Section 7.0.

\subsection{Simulation Tool Description}

EnergyPlus Version 3.0 (released in November 2008) ${ }^{1}$ was used to assess the energy savings potential of the recommended energy efficiency measures, and to perform analysis of the final recommendations in the design package. EnergyPlus is a building energy simulation program under development by DOE since 1996. It is a complex building energy simulation program for modeling building heating, cooling, lighting, ventilating, and other energy flows. While it is based on the most popular features and capabilities of BLAST and DOE-2, EnergyPlus includes many innovative simulation capabilities, such as time steps of less than 1 hour, modular systems and plants integrated with heat balance-based zone simulation, multi-zone air flow, thermal comfort, and renewable energy systems. EnergyPlus is a heavily tested program with formal validation efforts repeated for every release ${ }^{2}$.

All energy simulations were completed with PNNL's Linux energy simulation infrastructure that manages inputs and outputs of the EnergyPlus simulations. This infrastructure includes creating EnergyPlus input files by a PNNL-developed program known as gparm, submitting input files to a 50-

\footnotetext{
${ }^{1}$ For downloading the latest version of EnergyPlus program, go to http://apps1.eere.energy.gov/buildings/energyplus/getting.cfm. Last accessed on August 15, 2009.

${ }^{2}$ For the details of the test and validations of EnergyPlus program, go to http://apps1.eere.energy.gov/buildings/energyplus/testing.cfm. Last accessed on August 15, 2009.
} 
central processing unit (CPU) computing cluster for batch simulation, and energy end-use results extraction.

\subsection{Climate Zones and Construction Weights}

Prior to this report, the released $A E D G$ s developed to date have standardized climate zones that have been adopted by IECC as well as ASHRAE for both residential and commercial applications. This results in a common set of climate zones for use in codes and standards. The common set of climate zones includes 8 zones covering the entire United States, as shown in Figure 2.1 (Briggs et al. 2003). Climate zones are categorized from 1 to 8 , with increasing heating degree days (HDDs) and decreasing cooling degree days (CDDs). These climate zones may be mapped to other climate locations for international use. The climate zones are further divided into moist and dry regions. A specific climate location (city) is selected as a representative of each climate zone. The AEDG $30 \%$ series selected 15 cities as the representative climate locations.

For this project we selected a revised set of 16 cities that balance the representativeness of the climate zones and the number of buildings in the climate zones as shown below. The modified representative cites are also consistent with the DOE's Commercial Benchmark Building locations. Two locations were selected for climate zone $3 \mathrm{~B}$ because we felt that these are two important locations with very different climates, which is evident from the results of the energy simulations of the benchmark building models. We have designated the two $3 \mathrm{~B}$ climate zones as "3B-CA" for the California coast in climate zone 3B and "3B-other".

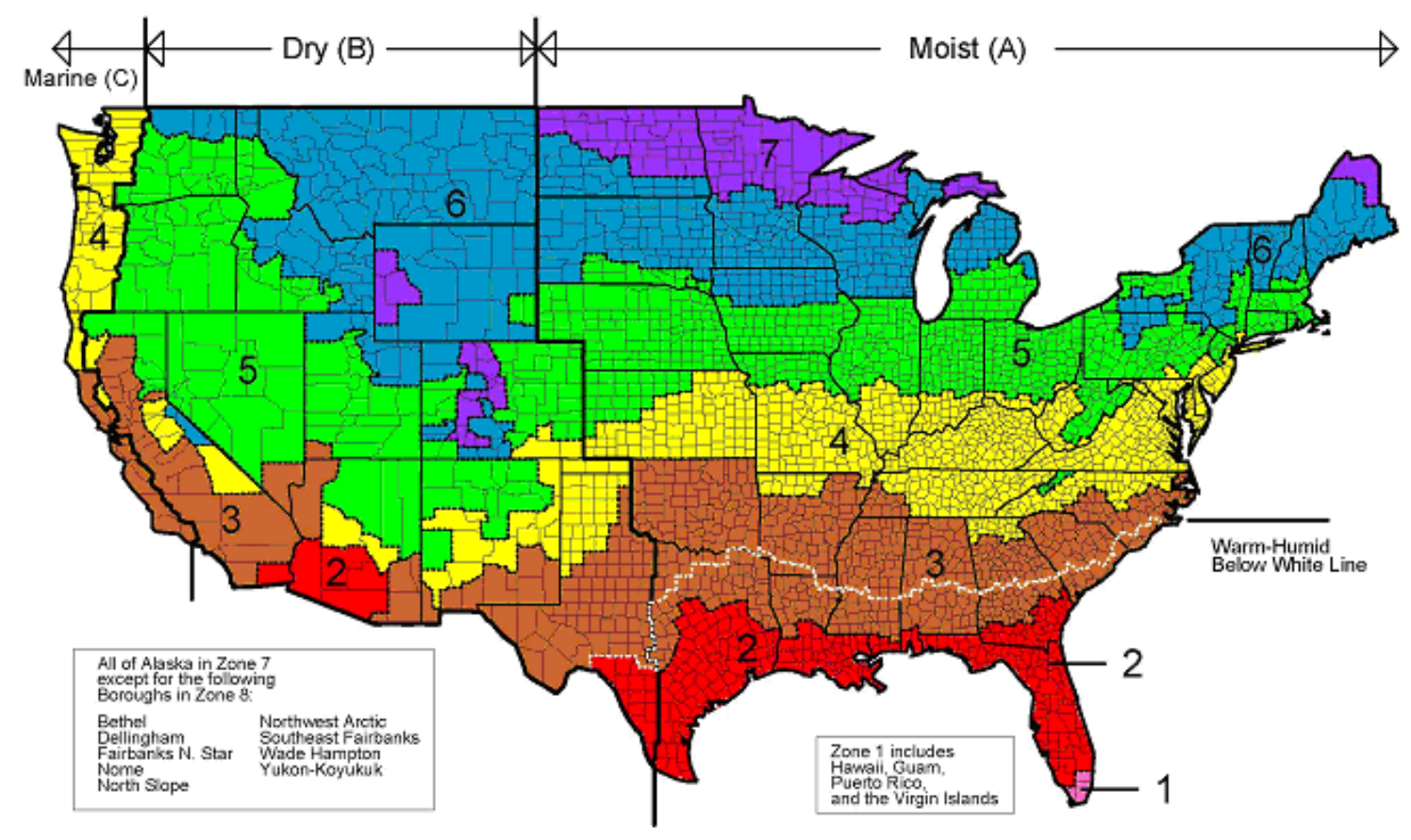

Figure 2.1. DOE-Developed Climate Zone Map 
The 16 cities representing the climate zones are:

1A: Miami, Florida (hot, humid)

2A: Houston, Texas (hot, humid)

2B: Phoenix, Arizona (hot, dry)

3A: Atlanta, Georgia (hot, humid)

3B-CA: Los Angeles, California (hot, dry)

3B-other: Las Vegas, Nevada (hot, dry)

3C: San Francisco, California (marine)

4A: Baltimore, Maryland (mild, humid)
4B: Albuquerque, New Mexico (mild, dry)

4C: Seattle, Washington (marine)

5A: Chicago, Illinois (cold, humid)

5B: Denver, Colorado (cold, dry)

6A: Minneapolis, Minnesota (cold, humid)

6B: Helena, Montana (cold, dry)

7: Duluth, Minnesota (very cold)

8: Fairbanks, Alaska (extreme cold)

These representative climate locations are assigned construction weights based on the square footage of construction from 2003 to 2007 as presented in a draft PNNL study which utilizes the McGraw-Hill Construction Projects Starts Database (MHC) (Jarnagin et al. 2009). This study presents weighting factors for all 16 prototypical buildings that PNNL have used to support the Standard 90.1-2010 development, as shown in Table 2.1 with highway lodging (referred as small hotel/motel in the table) shown in bold. Table 2.2 shows just the highway lodging weighting factors normalized to total $100 \%$ and labeled according to the representative cities shown above. The weights for highway lodging by climate locations are used to calculate weighted average energy savings results for the whole country in Section 7.0 including splitting the weight in half for climate zone 3B (dry) for each of two city locations, Los Angeles and Las Vegas. 
Table 2.1. Construction Volume Weights for All ASHRAE Building Prototypes and Climate Zones

\begin{tabular}{|c|c|c|c|c|c|c|c|c|c|c|c|c|c|c|c|c|c|}
\hline No. & Prototype & 1 moist & 2 dry & 2 moist & 3 dry & $\begin{array}{c}3 \\
\text { marine }\end{array}$ & 3 moist & 4 dry & $\begin{array}{c}4 \\
\text { marine }\end{array}$ & 4 moist & 5 dry & 5 moist & 6 dry & 6 moist & 7 & 8 & National \\
\hline 1 & Large Office & $0.102 \%$ & $0.061 \%$ & $0.326 \%$ & $0.285 \%$ & $0.117 \%$ & $0.445 \%$ & $0.000 \%$ & $0.154 \%$ & $1.132 \%$ & $0.121 \%$ & $0.442 \%$ & $0.000 \%$ & $0.133 \%$ & $0.011 \%$ & $0.000 \%$ & $3.327 \%$ \\
\hline 2 & $\begin{array}{l}\text { Medium } \\
\text { Office }\end{array}$ & $0.129 \%$ & $0.292 \%$ & $0.813 \%$ & $0.715 \%$ & $0.136 \%$ & $0.766 \%$ & $0.036 \%$ & $0.196 \%$ & $1.190 \%$ & $0.342 \%$ & $1.060 \%$ & $0.035 \%$ & $0.298 \%$ & $0.033 \%$ & $0.007 \%$ & $6.047 \%$ \\
\hline 3 & Small Office & $0.084 \%$ & $0.289^{\circ}$ & $1.064 \%$ & $0.475 \%$ & $0.078 \%$ & $0.963 \%$ & $0.047 \%$ & $0.123 \%$ & $0.936 \%$ & $322 \%$ & $0.920 \%$ & $0.030 \%$ & $0.241 \%$ & $0.032 \%$ & $.005 \%$ & $5.608 \%$ \\
\hline 4 & $\begin{array}{l}\text { Standalone } \\
\text { Retail }\end{array}$ & $0.224 \%$ & $0.507 \%$ & $2.220 \%$ & $1.250 \%$ & $0.191 \%$ & $2.386 \%$ & $0.119 \%$ & $0.428 \%$ & $2.545 \%$ & $0.792 \%$ & $3.429 \%$ & $0.091 \%$ & $0.948 \%$ & $0.109 \%$ & $0.014 \%$ & $15.254 \%$ \\
\hline 5 & Strip Mall & $0.137 \%$ & $0.254 \%$ & $0.991 \%$ & $0.626 \%$ & $0.103 \%$ & $1.021 \%$ & $0.023 \%$ & $0.107 \%$ & $1.008 \%$ & $0.201 \%$ & $1.023 \%$ & $0.016 \%$ & $0.153 \%$ & $0.007 \%$ & $0.001 \%$ & $5.669 \%$ \\
\hline 6 & & $64 \%$ & $0.164 \%$ & $33 \%$ & $0.446 \%$ & $0.048 \%$ & $0.944 \%$ & $0.030 \%$ & $0.094 \%$ & $0.895 \%$ & 0.2 & $0.920 \%$ & $0.037 \%$ & $0.168 \%$ & $0.023 \%$ & $0.003 \%$ & $4.994 \%$ \\
\hline 7 & $\begin{array}{l}\text { Secondary } \\
\text { School } \\
\end{array}$ & $0.160 \%$ & $0.230 \%$ & $1.523 \%$ & $0.819 \%$ & $0.109 \%$ & $1.893 \%$ & $0.063 \%$ & $0.243 \%$ & $2.013 \%$ & $0.438 \%$ & $2.282 \%$ & $0.086 \%$ & $0.415 \%$ & $0.075 \%$ & $0.012 \%$ & $10.361 \%$ \\
\hline 8 & Hospital & $40 \%$ & $0.096 \%$ & $479 \%$ & $\%$ & $0.039 \%$ & $0468 \%$ & $\%$ & $0.106 \%$ & $5 \%$ & $0218 \%$ & $.812 \%$ & $0.024 \%$ & $0.221 \%$ & $.034 \%$ & $001 \%$ & $3.448 \%$ \\
\hline 9 & & $0.037 \%$ & $0.134 \%$ & $0.567 \%$ & $0.275 \%$ & $0.061 \%$ & $0.581 \%$ & $0.023 \%$ & $0.181 \%$ & $0.818 \%$ & $0.218 \%$ & $1.058 \%$ & $0.033 \%$ & $0.342 \%$ & $0.039 \%$ & $0.002 \%$ & $4.371 \%$ \\
\hline 10 & Restaurant & $0.009 \%$ & $0.025 \%$ & $0.106 \%$ & $0.047 \%$ & $0.006 \%$ & $0.111 \%$ & $0.006 \%$ & $0.010 \%$ & $0.127 \%$ & $0.031 \%$ & $0.143 \%$ & $0.004 \%$ & $0.031 \%$ & $0.004 \%$ & $0.000 \%$ & $0.660 \%$ \\
\hline 11 & $\begin{array}{l}\text { Fast Food } \\
\text { Restaurant }\end{array}$ & $0.008 \%$ & $0.020 \%$ & $0.092 \%$ & $0.063 \%$ & $0.007 \%$ & $0.102 \%$ & $0.005 \%$ & $0.014 \%$ & $0.089 \%$ & $0.026 \%$ & $0.128 \%$ & $0.003 \%$ & $0.025 \%$ & $0.004 \%$ & $0.000 \%$ & $0.587 \%$ \\
\hline 12 & Large Hotel & O 1000 & $0.125 \%$ & & $0.793 \%$ & $06 \%$ & & 0270 & $123 \%$ & $\%$ & & & $\%$ & $0.227 \%$ & $038 \%$ & $.004 \%$ & $4.951 \%$ \\
\hline 13 & II $1 /$ motel & $10 \%$ & $0.030 \%$ & $0.288 \%$ & $0.114 \%$ & $0.022 \%$ & $0.268 \%$ & $0.020 \%$ & $0.039 \%$ & $0.315 \%$ & $0.089 \%$ & $0.365 \%$ & $0.031 \%$ & $0.107 \%$ & $0.020 \%$ & $0.004 \%$ & $1.721 \%$ \\
\hline 14 & $\begin{array}{l}\text { Non- } \\
\text { refrigerated } \\
\text { warehouse }\end{array}$ & & $0.580 \%$ & & 2.23 & $0.154 \%$ & & & $0.435 \%$ & $2.446 \%$ & & & $0.049 \%$ & $0.466 \%$ & $0.043 \%$ & $0.002 \%$ & $16.716 \%$ \\
\hline 15 & $\begin{array}{l}\text { High-1 } \\
\text { apartm }\end{array}$ & 法 & $0.076 \%$ & $1.512 \%$ & $0.741 \%$ & $0.173 \%$ & $0.652 \%$ & $0.000 \%$ & $0.358 \%$ & $2.506 \%$ & $0.115 \%$ & $1.163 \%$ & $0.016 \%$ & $0.125 \%$ & $0.008 \%$ & $0.000 \%$ & $8.967 \%$ \\
\hline 16 & $\begin{array}{l}\text { Mid-rise } \\
\text { apartment }\end{array}$ & $0.257 \%$ & $0.093 \%$ & $1.094 \%$ & $0.862 \%$ & $0.260 \%$ & $0.825 \%$ & $0.022 \%$ & $0.371 \%$ & $1.694 \%$ & $0.318 \%$ & $1.122 \%$ & $0.056 \%$ & $0.313 \%$ & $0.032 \%$ & $0.000 \%$ & $7.321 \%$ \\
\hline & Totals & $3.242 \%$ & $2.975 \%$ & $15.217 \%$ & $10.081 \%$ & $1.609 \%$ & $15.025 \%$ & $0.522 \%$ & $2.981 \%$ & $19.286 \%$ & $4.344 \%$ & $19.366 \%$ & $0.569 \%$ & $4.214 \%$ & $0.513 \%$ & $0.056 \%$ & $100.0 \%$ \\
\hline
\end{tabular}

Table 2.2. Construction Weights for Highway Lodging

\begin{tabular}{|c|c|c|c|c|c|c|c|c|c|c|c|c|c|c|c|c|}
\hline $\begin{array}{c}1 \mathrm{~A} \\
\text { Miami }\end{array}$ & $\begin{array}{c}2 \mathrm{~A} \\
\text { Houston }\end{array}$ & $\begin{array}{c}\text { 2B } \\
\text { Phoenix }\end{array}$ & $\begin{array}{c}3 \mathrm{~A} \\
\text { Atlanta } \\
\end{array}$ & $\begin{array}{c}\text { 3B-CA } \\
\text { Los } \\
\text { Angeles }\end{array}$ & $\begin{array}{c}\text { 3B- } \\
\text { other } \\
\text { Las } \\
\text { Vegas }\end{array}$ & $\begin{array}{c}3 \mathrm{C} \\
\text { San } \\
\text { Francisco }\end{array}$ & $\begin{array}{c}4 \mathrm{~A} \\
\text { Baltimore }\end{array}$ & $\begin{array}{c}\text { 4B } \\
\text { Albuquerque }\end{array}$ & $\begin{array}{c}4 \mathrm{C} \\
\text { Seattle }\end{array}$ & $\begin{array}{c}5 \mathrm{~A} \\
\text { Chicago }\end{array}$ & $\begin{array}{c}5 \mathrm{~B} \\
\text { Denver }\end{array}$ & $\begin{array}{c}\text { 6A } \\
\text { Minneapolis }\end{array}$ & $\begin{array}{c}6 \mathrm{~B} \\
\text { Helena } \\
\end{array}$ & $\begin{array}{c}7 \\
\text { Duluth }\end{array}$ & $\begin{array}{c}8 \\
\text { Fairbanks } \\
\end{array}$ & Total \\
\hline $0.58 \%$ & $16.73 \%$ & $1.74 \%$ & $15.57 \%$ & $3.31 \%$ & $3.31 \%$ & $1.28 \%$ & $18.30 \%$ & $1.16 \%$ & $2.27 \%$ & $21.21 \%$ & $5.17 \%$ & $6.22 \%$ & $1.80 \%$ & $1.16 \%$ & $0.23 \%$ & $100 \%$ \\
\hline
\end{tabular}




\subsection{Development of Prototypical Building}

The first step of the energy savings analysis is development of prototypical building. This section summarizes the development of the highway lodging prototype used for the energy analysis in this design package. Currently available data sources representing highway lodging new construction as well as the existing building stock are summarized. The process of how the characteristics of the highway lodging prototype were developed is also documented. Table B.1 (Appendix B) summarizes the building characteristics for the highway lodging prototype, which remain the same for the baseline buildings and advanced buildings and are not affected by Standard 90.1-2004. Many of the assumptions that are used for this analysis originated during the development of the Advanced Energy Design Guide (AEDG) for Highway Lodging Buildings (ASHRAE 2009). Readers can also refer to the Technical Support Document for the Development of Advanced Energy Design Guide for Highway Lodging Building (Jiang et al. 2008) for detailed documentation of the prototypical building assumptions.

The highway lodging prototype is a theoretical building modeled with characteristics typical of a building of this size and use. The building form, space configuration, construction type and guest room sizes were adapted from a Hampton Inn prototype floor plan used in the AEDG-HL large prototype. This highway lodging prototype is a wide, rectangular, four-story building with a total floor area of $43,000 \mathrm{ft}^{2}$ $\left(3,995 \mathrm{~m}^{2}\right)$. There are 77 guest rooms accounting for $63 \%$ of the total floor area, and include large public use areas for lobby, office, meeting room, laundry room, exercise room, etc. The floor-to-ceiling height is $11 \mathrm{ft}(3.35 \mathrm{~m})$ for the ground floor and $9 \mathrm{ft}(2.74 \mathrm{~m})$ for the second through fourth floor.

\subsection{Data Sources}

The data sets that were used to help form the highway lodging building prototype for the energy analysis include the following:

- $\quad$ the 2003 Commercial Building Energy Consumption Survey (2003 CBECS) (EIA 2006) ${ }^{1}$

- the F.W. Dodge Database ${ }^{2}$

- New Commercial Construction Characteristics $\left(\mathrm{NC}^{3}\right)$ Database ${ }^{3}$

- the 2008 Lodging Industry Profile (AHLA 2008)

- additional data sets from the AEDG-HL project committee, including actual floor flans for Hampton Inn Prototype (Hampton Inn 2008), plug loads, and so on.

The CBECS data sets are publicly available and provide statistically valid results from a periodic national survey of commercial buildings and their energy suppliers performed by the Energy Information Administration (EIA). While the design package is intended for new construction, some building characteristics in new constructions are almost the same as existing construction. Furthermore, it can provide information about common characteristics of highway lodging buildings, which is critical to the

\footnotetext{
${ }^{1}$ The results of the 2003 CBECS surveys are available as downloadable reports and micro-data files from the EIA website (http://www.eia.doe.gov/emeu/cbecs/). The $2003 \mathrm{CBECS}$ is the most recent data set available.

${ }^{2} \mathrm{http}$ ://dodge.construction.com/analytics/MarketMeasurement/BuildingStockDatabase.asp

${ }^{3}$ National Commercial Construction Characteristics Database $\left(\mathrm{NC}^{3}\right)$, an internal database developed by Pacific Northwest National Laboratory with DOE Building Technologies Program support to represent nationwide commercial construction energy-related characteristics.
} 
prototypical building development. In the 2003 CBECS survey, 4,859 buildings were surveyed, and the sampled buildings were given base weights (CBECS variable "ADJWT8") to represent the entire stock of commercial buildings in the United States. The 2003 CBECS contains a total of 260 surveyed lodging buildings, separated into four sub-categories: 1) hotel, 2) motel or inn, 3) dormitory/fraternity/sorority, and 4) other lodging.

The F.W. Dodge Database provides detailed historical and forecast databases of construction activity. It contains extensive, comprehensive coverage of existing building space throughout the United States. Up to 20 years of historical data is combined with up to 25 years of forecast data for 15 different project types. Details include floor space, number of buildings, and so on.

$\mathrm{NC}^{3}$ is an internal PNNL database of nationwide commercial construction energy-related characteristics developed based on building characteristics taken from McGraw Hill/F.W. Dodge commercial building plans submitted for construction bids (Richman et al. 2008). The current database includes over 300 commercial buildings.

One of the primary sources that were used for developing the prototype was the actual floor plans for Hampton Inn Prototype (shown in Figure 3.1 and Figure 3.2). ${ }^{4}$ The Hampton Inn Prototype floor plans were provided by one of the AEDG-HL project committee members, and the plans provided detailed information for a typical highway lodging building — such as building form, space configuration, construction type, and so on.

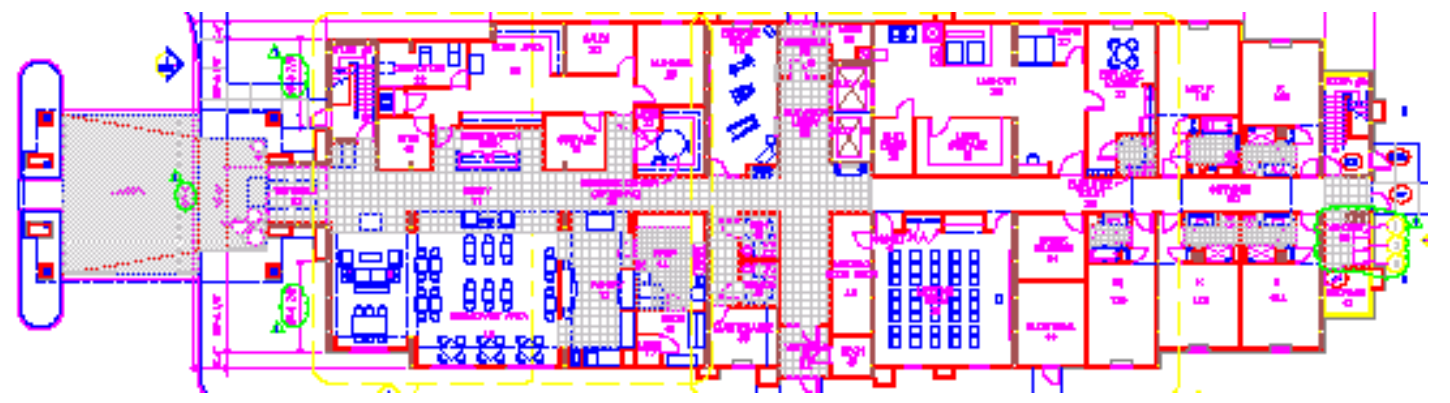

Figure 3.1. Hampton Inn Prototype Ground Floor Plan

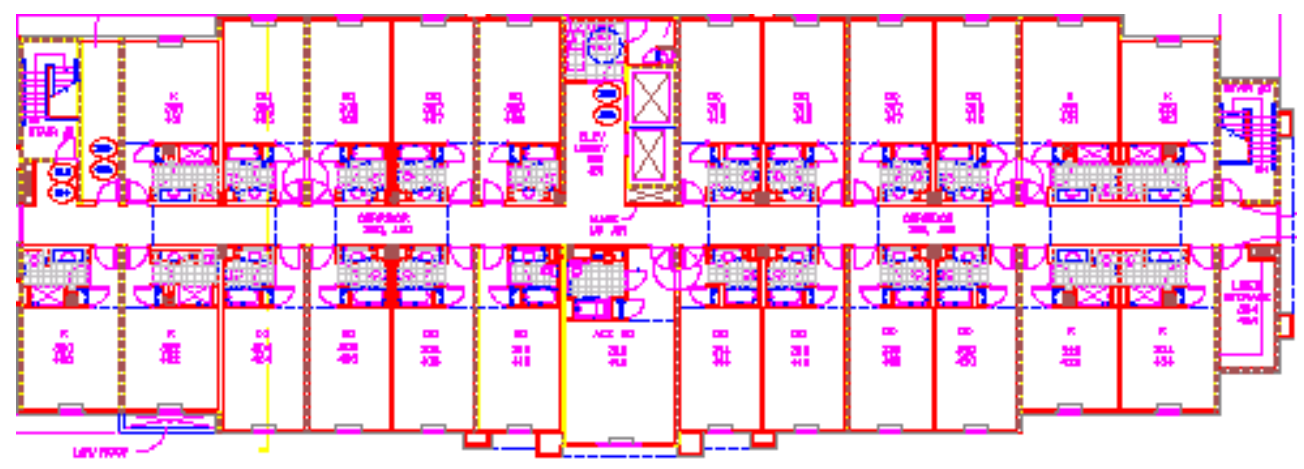

Figure 3.2. Hampton Inn Prototype Typical Floor Plan

\footnotetext{
${ }^{4}$ The Hampton Inn prototype floor plans are downloaded from: http://www.hamptonfranchise.com/Index.asp?S=3\&P=23
} 


\subsection{Building Form}

According to the categories contained in American Hotel \& Lodging Association (AHLA) Lodging Industry Profile report, highway lodging is defined as smaller hotel and motel properties typically found along highways and those found in smaller cities and towns (AHLA 2008). This would include the following:

- properties designed for short-stay occupancy

- properties intended to serve the basic lodging needs of typical business and non-business travelers

- properties that do not contain substantial food-service facilities.

The scope of the AEDG-HL specifically covers hotels up to 80 rooms, typically four stories or less, that use unitary heating and air-conditioning equipment. The F.W. Dodge Database for new construction as well as the actual floor plans for the Hampton Inn Prototype was used for developing the 43,000 $\mathrm{ft}^{2}$ $\left(3,995 \mathrm{~m}^{2}\right)$ highway lodging prototype. Some of the assumptions were further verified and supplemented by the CBECS data.

The CBECS survey asks questions about building shape (square, wide rectangle, "L" shape, other) and the data report that about $53 \%$ of hotel/motel buildings that have less than 80 rooms are wide rectangular shape and $18 \%$ of highway lodging buildings are "L" shape (shown in Figure 3.3). This finding is consistent with the assumption of a wide rectangular building prototype.

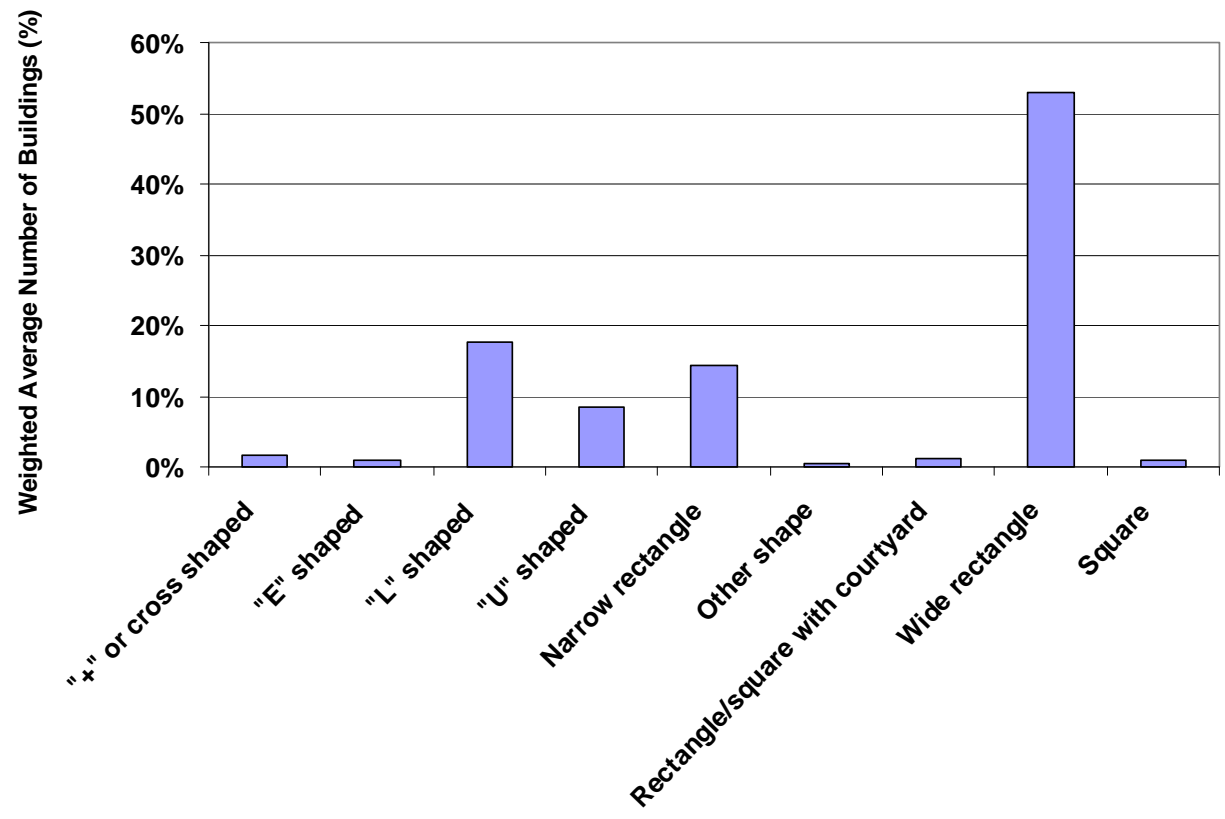

Figure 3.3. Building Shape Distribution in 2003 CBECS (for motels/hotels with less than 80 rooms)

A close look at the F.W. Dodge Database suggested that the majority of hotel/motel buildings from 1999 to 2005 are approximately $45,000 \mathrm{ft}^{2}\left(4,181 \mathrm{~m}^{2}\right)$ in size, as shown in Figure 3.4. One of the AEDGHL project committee members provided access to the detailed floor plans for the Hampton Inn Prototype, which was used as the base for developing the building configuration for the highway lodging prototype. The highway lodging prototype (Hampton Inn Prototype) was a wide, rectangular, four-story 
building and has 77 guest rooms, accounting for $63 \%$ of the total floor space. The size of the building was approximately $43,000 \mathrm{ft}^{2}\left(3,995 \mathrm{~m}^{2}\right)$. Aside from the living space, the public space mainly contained lobby, office, corridor, meeting room, laundry room, exercise room, etc.

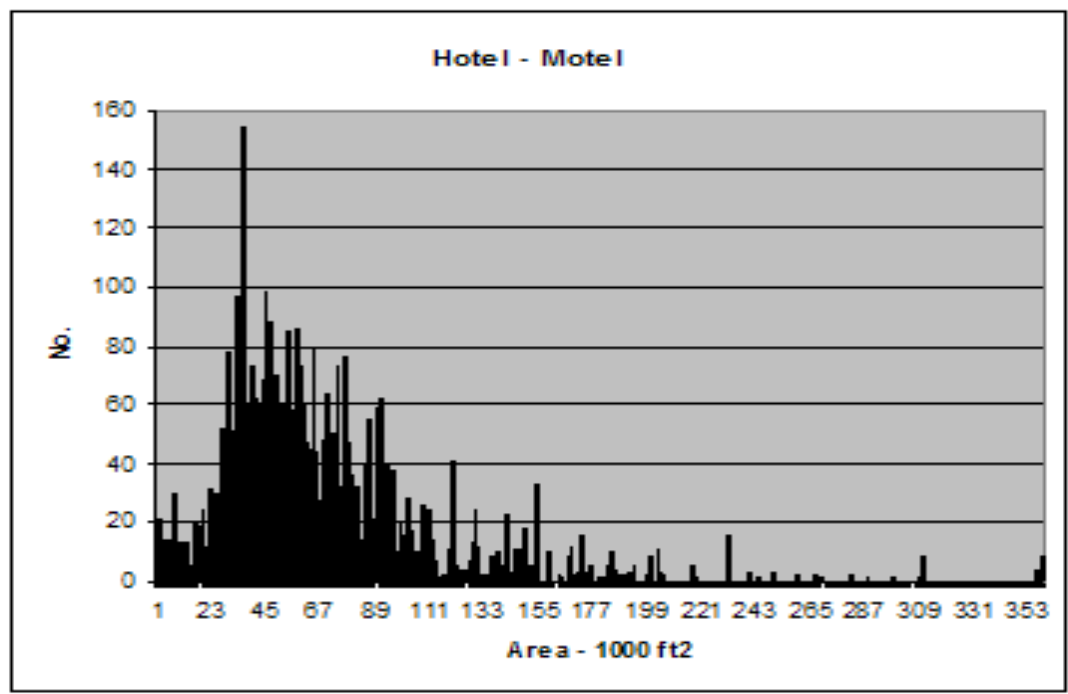

Figure 3.4. Hotel/Motel Building Number vs. Floor Area Distribution from F.W. Dodge Database

Table 3.1 summarizes all the space types in this prototype as well as the floor area percentage for each space type. Based on the floor plans, it was assumed that the floor-to-ceiling height was $11 \mathrm{ft}$ $(3.35 \mathrm{~m})$ for the ground floor and $9 \mathrm{ft}(2.74 \mathrm{~m})$ for the second through the fourth floor. Figure 3.5 shows the exterior view and floor plan for this prototype.

Table 3.1. Highway Lodging Prototype Space Type

\begin{tabular}{lr}
\hline \multicolumn{1}{c}{ Space Type } & Floor Area Percentage \\
\hline Guest rooms & $63 \%$ \\
Corridor & $13 \%$ \\
\hline Lobby/lounge & $4 \%$ \\
Stairs & $4 \%$ \\
\hline Storage & $3 \%$ \\
Office/reception & $3 \%$ \\
Meeting room & $2 \%$ \\
Laundry room & $2 \%$ \\
Elevator & $2 \%$ \\
Employee lounge & $1 \%$ \\
Restrooms & $1 \%$ \\
Exercise room & $1 \%$ \\
Mechanical room & $1 \%$ \\
Total floor area & $100 \%$ \\
\hline
\end{tabular}




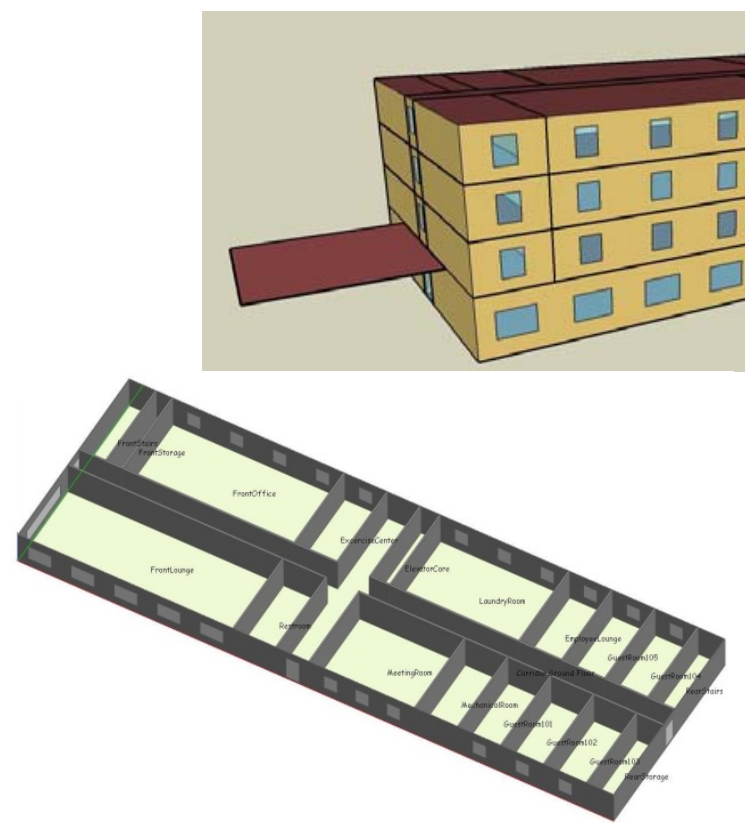

Ground Floor

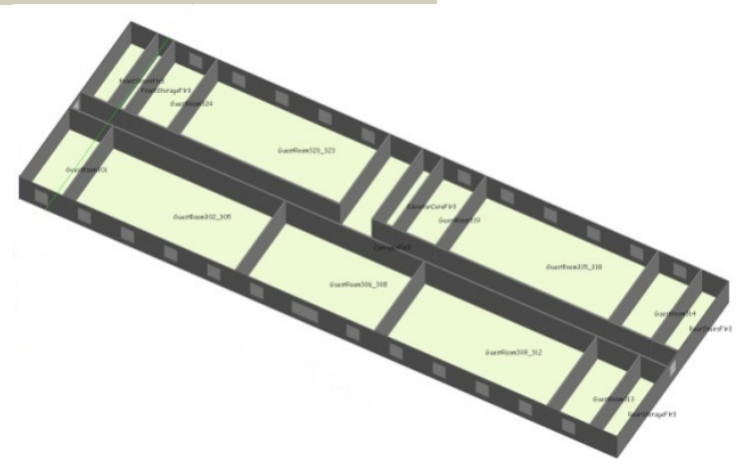

Typical Floor

Figure 3.5. Axonometric View and Floor Plans of the 43,000 $\mathrm{ft}^{2}\left(3,995 \mathrm{~m}^{2}\right)$ Highway Lodging Prototype

\subsection{Envelope Construction}

The AEDG-HL project committee assumed, based on experience of those in the construction industry, that the $43,000 \mathrm{ft}^{2}\left(3,995 \mathrm{~m}^{2}\right)$ highway lodging prototype was typically constructed with mass walls as exterior walls, built-up roof, and slab-on-grade floors. These assumptions are also consistent with the Hampton Inn Prototype. These envelope structures represent common construction practices for highway lodging buildings in the United States.

The window size of the prototype was obtained from the actual Hampton Inn Prototype floor plans, which was $5 \mathrm{ft}(1.52 \mathrm{~m})$ by $6 \mathrm{ft}(1.83 \mathrm{~m})$. The window-to-wall ratio (WWR) was calculated to be $11 \%$. In the 2003 CBECS data, a "percent exterior glass" variable is reported for each building in one of the five bins (i.e., "10 percent or less," "11-25 percent," etc.). The data show that $40 \%$ of the hotel $/$ motel buildings that have less than 80 rooms fall into " $11-25$ percent" category, while $37 \%$ fall in the " $10 \%$ or less" category (Figure 3.6). Therefore, the assumptions of the window area for the prototypes were also consistent with CBECS data.

The CBECS asks whether the building has skylights. The 2003 CBECS data shows about $88 \%$ of hotel/motel buildings that have less than 80 rooms also do not have skylights. The Hampton Inn Prototype also does not have skylights. Therefore, it was assumed that the prototypical building had no skylights. It was also assumed that there was no overhang for the prototype based on the Hampton Inn prototype.

In summary, the $43,000 \mathrm{ft}^{2}\left(3,955 \mathrm{~m}^{2}\right)$ highway lodging prototype is a 4-story rectangular building with $180 \mathrm{ft}$ length $(55 \mathrm{~m})$ by $60 \mathrm{ft}$ depth $(18.3 \mathrm{~m}$ ) (aspect ratio of 3 ). Building opaque constructions include walls composed of concrete masonry units, flat roof with insulation above the deck, and slab-on- 
grade floors. Glazing is distributed based on the configuration of the guest rooms, with window area being $11 \%$ to $25 \%$ of total gross wall area.

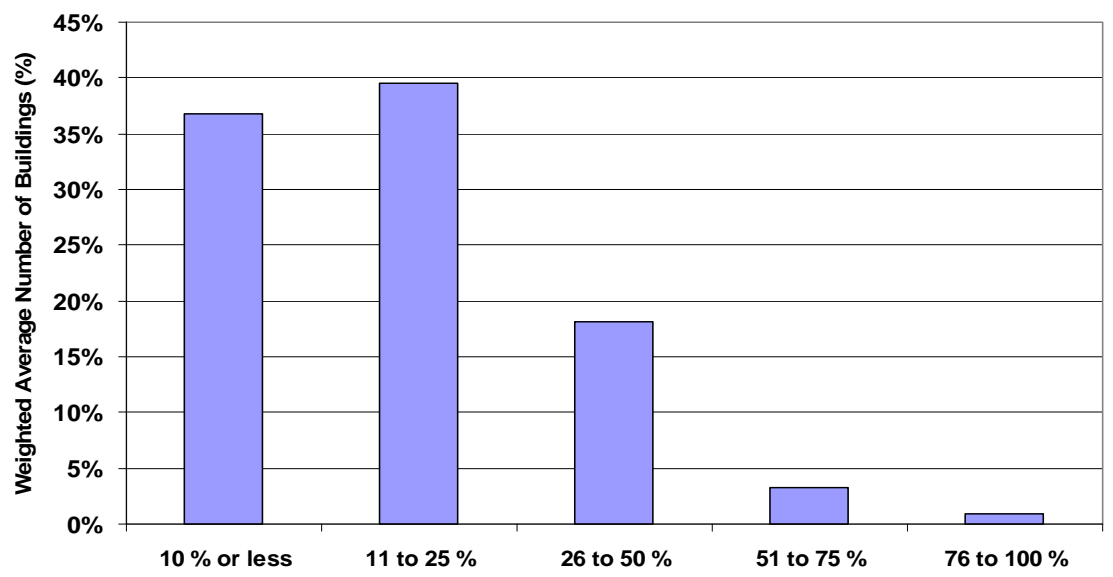

Figure 3.6. WWR Distribution for Motel/Hotel Buildings with Less than 80 Rooms in 2003 CBECS

\subsection{Air Infiltration}

The Standard 90.1-2004 does not specify a requirement for maximum air infiltration rate. Building air infiltration is addressed only indirectly in the Standard through the requirements for building envelope sealing, fenestration and door air leakage, etc. For this analysis, the infiltration rate was assumed to be $1.8 \mathrm{cfm} / \mathrm{ft}^{2}\left(0.00915 \mathrm{~m}^{3} / \mathrm{s} / \mathrm{m}^{2}\right)$ of above-grade envelope surface area at 0.3 in. w.c. ( $\left.75 \mathrm{~Pa}\right)$ based on the study by the National Institute of Standards and Technologies (Emmerich et al. 2005).

The EnergyPlus program offers three methods for addressing infiltration: 1) constant infiltration (EnergyPlus default), 2) DOE-2 methodology which accounts for wind driven pressure differences, and 3 ) the BLAST methodology which accounts for wind pressure and stack driven temperature differences. Based on the results of PNNL's study on infiltration modeling methodology, the DOE-2 method was utilized.

PNNL has developed the following methodology to convert the infiltration rate at 0.3 in. w.c. (75 Pa) to a corresponding wind-driven design infiltration rate input in EnergyPlus:

Step 1: Calculate the average wind-driven building pressure on all walls of a building of height with a wind velocity calculated at the roof line and normal to one wall of the building using existing wind pressure formulations (Swami and Chandra 1987).

Step 2: Integrate the positive wind-driven building pressure for all angles of wind to get an average positive wind pressure across all wall surfaces as a function of wind velocity. (This step is necessary because the wind speed correlations in EnergyPlus are independent of direction).

Step 3: Calculate the infiltration in the building at an average surface pressure from Step 2 and a reference wind speed at the roof line (e.g. $10 \mathrm{mph}$ ) by multiplying the infiltration at 0.3 in. w.c. (75 Pa) whole building pressure difference by the ratio of the average wind pressure from Step 2 to 0.3 in. w.c. 
(75 Pa), as modified using a flow exponent 0.65 . This provides the average infiltration rate across the wall surfaces based on the wind speed measured at the roof line.

Step 4: Adjust the calculated infiltration rate from Step 3 so that it can be correctly used as EnergyPlus input by multiplying it by the ratio of the wind speed at the roof line to the average wind speed impinging on a building wall with outward surface normal anti-parallel to the wind direction. This ratio can be calculated using a power-law wind profile based on the same site terrain as in the EnergyPlus model. (This is necessary because the infiltration calculations in EnergyPlus use the wind speed at the center height of each exterior wall above ground.).

Following the above methodology, the EnergyPlus input design infiltration $\left(\mathrm{I}_{\text {design }}\right)$ was calculated as $0.2016 \mathrm{cfm} / \mathrm{ft}^{2}\left(0.001024 \mathrm{~m}^{3} / \mathrm{s} / \mathrm{m}^{2}\right)$ of above-grade exterior wall surface area, equivalent to the base infiltration rate of $1.8 \mathrm{cfm} / \mathrm{ft}^{2}\left(0.00915 \mathrm{~m}^{3} / \mathrm{s} / \mathrm{m}^{2}\right)$ of above-grade envelope surface area at 0.3 in. w.c. (75 Pa).

In addition, an infiltration schedule is input in EnergyPlus to diversify the peak infiltration rate calculated above. The schedule assumes full infiltration when the HVAC system is scheduled "off" and $25 \%$ infiltration when the HVAC system is switched "on." 


\subsection{Development of Baseline Building Model and Assumptions}

The baseline models are constructed in a manner similar to what was used in the AEDG TSDs (Jarnagin et al. 2006; Liu et al. 2006; Liu et al. 2007; Pless et al. 2007, Jiang et al. 2008). In the baseline model, building components that are regulated by ASHRAE Standard 90.1-2004 are assumed to "just meet" the minimum prescriptive requirements of that standard. Components that are not regulated by Standard 90.1 are assumed to be designed as is standard practice for a highway lodging building. Standard practice is determined from various sources including a review of CBECS data and the input of various design and construction industry professionals. The following sections include a topic-by-topic review of the baseline building and how the baseline building is simulated in EnergyPlus, including characteristics of the building envelope (including infiltration), building internal loads (people, lighting, plug load, and miscellaneous equipment), HVAC system, and service water heating.

\subsection{Envelope}

The baseline building envelope characteristics were developed to meet prescriptive design requirements in accordance with ASHRAE Standard 90.1-2004 Section 5.3, Prescriptive Building Envelope Option. Most of the spaces in lodging buildings are guest rooms, which are defined as residential spaces according to the Standard. Because $84 \%$ of the spaces on the ground floor of the prototype highway lodging building are non-residential spaces and $79 \%$ of the spaces on floors two through four are guest rooms, it was decided that the envelope requirements for the spaces on the ground floor shall meet the criteria for non-residential conditioned space, and the envelope requirements for the spaces on the remaining floors shall meet the criteria for residential conditioned space.

The EnergyPlus program can calculate the U-factor of opaque assemblies by defining the properties of materials, layers and construction. This method was used in this analysis to properly account for thermal mass impacts on the calculations of space loads. The following section describes the assumptions used for modeling the baseline building envelope components, including the exterior walls, roofs, slabon-grade floors, fenestration, infiltration, and roof absorbance.

\subsubsection{Exterior Walls}

The exterior walls are constructed of 8 -in. $(150 \mathrm{~mm})$ medium weight concrete blocks with a density of $115 \mathrm{lb} / \mathrm{ft}^{3}\left(1842 \mathrm{~kg} / \mathrm{m}^{3)}\right.$ and solid grouted cores. The mass wall includes the following layers:

- Exterior air film, R- $0.17^{\circ} \mathrm{F} \cdot \mathrm{h} \cdot \mathrm{ft}^{2} / \mathrm{Btu}\left(0.03 \mathrm{~K} \cdot \mathrm{m}^{2} / \mathrm{W}\right)$

- Concrete block, 8-in. $(150 \mathrm{~mm}), 115 \mathrm{lb} / \mathrm{ft}^{3}\left(1842 \mathrm{~kg} / \mathrm{m}^{3}\right)$ with R-0.87 ${ }^{\circ} \mathrm{F} \cdot \mathrm{h} \cdot \mathrm{ft}^{2} / \mathrm{Btu}\left(0.153 \mathrm{~K} \cdot \mathrm{m}^{2} / \mathrm{W}\right)$

- Rigid insulation, held in place with 1-in. $(25 \mathrm{~mm})$ metal clips (insulation thickness varies by climate and residential vs. commercial requirement)

- 0.5 -in. (13 mm) gypsum board, R-0.45 ${ }^{\circ} \mathrm{F} \cdot \mathrm{h} \cdot \mathrm{ft}^{2} / \mathrm{Btu}\left(0.08 \mathrm{~K} \cdot \mathrm{m}^{2} / \mathrm{W}\right)$, if insulation is present

- Interior air film, R-0.68 ${ }^{\circ} \mathrm{F} \cdot \mathrm{h} \cdot \mathrm{ft}^{2} / \mathrm{Btu}\left(0.12 \mathrm{~K} \cdot \mathrm{m}^{2} / \mathrm{W}\right)$. 
R-values for most of the above layers were derived from Appendix A (Rated R-Value of Insulation and Assembly U-Factor, C-Factor, and F-Factor Determination) of the Standard. Insulation R-values were selected to create a wall assembly that just meets the maximum U-value required in Tables 5.5.1 through 5.5.8 of the Standard (Building Envelope Requirements), as defined by climate zone.

\subsubsection{Roofs}

The flat roof consists of a roof membrane over rigid insulation, uninterrupted by framing, over a structural metal deck. Roof insulation R-values were also set to match the maximum roof U-value requirements in Tables 5.5.1 through 5.5.8 (Building Envelope Requirements) of the Standard, by climate. The roof construction is defined with the following layers:

- Exterior air film, R- $0.17^{\circ} \mathrm{F} \cdot \mathrm{h} \cdot \mathrm{ft}^{2} / \mathrm{Btu}\left(0.03 \mathrm{~K} \cdot \mathrm{m}^{2} / \mathrm{W}\right)$

- Continuous rigid insulation (thickness and R-value vary by climate)

- $\quad$ Metal deck (R-0)

- Interior air film heat flow up, R-0.61 ${ }^{\circ} \mathrm{F} \cdot \mathrm{h} \cdot \mathrm{ft}^{2} / \mathrm{Btu}\left(0.11 \mathrm{~K} \cdot \mathrm{m}^{2} / \mathrm{W}\right)$.

The Standard does not specify either roof reflectivity or emittance. In the baseline prototypes, the roof exterior finish was chosen as a single-ply roof membrane of grey EPDM (ethylene-propylenedieneterpolymer membrane). From a cool roofing materials database by the Lawrence Berkeley National Laboratory (LBNL 2009), the solar reflectance of the grey EPDM was assumed to be 0.23 and the corresponding emittance was assumed to be 0.87 .

\subsubsection{Slab-On-Grade Floors}

The base assembly for the ground floor is carpet over 6-in. concrete slab-on-grade floor poured directly on to the earth. Modeled below the slab is 12 -in. $(300 \mathrm{~mm})$ soil, with soil conductivity of $0.75 \mathrm{Btu} /{ }^{\circ} \mathrm{F} \cdot \mathrm{ft}^{2}\left(0.132 \mathrm{~K} \cdot \mathrm{m}^{2} / \mathrm{W}\right)$. In contrast to the U-factor for other envelope assemblies, the F-factor is set to match the minimum requirements for unheated slab-on-grade floors in Tables 5.5.1 through 5.5.8 of the Standard, based on climate. F-factor is expressed as the conductance of the surface per unit length of building perimeter, in the unit of $\mathrm{Btu} /{ }^{\circ} \mathrm{Fh} \cdot \mathrm{ft}$. Chapter 5 of the Standard also provides the corresponding R-values of the vertical insulation when required by the Standard (climate Zones 7 and 8). This continuous insulation is typically applied directly to the slab exterior, extending downward from the top of the slab for the distance specified.

One of the advanced features of the EnergyPlus program is that the conduction calculations of the ground heat-transfer through ground-contact surfaces (i.e., slab-on-grade floors) are two- or threedimensional rather than the simplified one-dimensional, as in other simulation programs (i.e., DOE-2). To use this method, the appropriate ground temperature is determined by the Slab program, a preprocessor that is one of the Auxiliary EnergyPlus programs. Then the calculated custom monthly average ground temperatures were manually transferred directly into EnergyPlus for each of 15 climate locations.

The Slab program requires the following key inputs to calculate the ground temperatures:

- Slab material and soil density 
- $\quad$ Building height

- Indoor average temperature set point

- R-value and depth of vertical insulation (if presented)

- Thickness of slab-on-grade

- The floor area to perimeter length ratio for this slab

- Distance from edge of slab to domain edge.

\subsubsection{Fenestration}

The window size and window-to-wall ratio for the prototype highway lodging building was based on actual plans for the Hampton Inn Prototype, which was determined to be typical for this type of hotel. Window size was 5 -ft $(1.52 \mathrm{~m})$ wide by 6 - $\mathrm{ft}(1.83 \mathrm{~m})$ tall and the window-to-wall-ratio was $11 \%$.

Chapter 5 of Standard 90.1- 2004 lists U-factor and solar heat gain coefficient (SHGC) requirements based on climate zone, window-to-wall ratio, and window operator type (fixed or operable). Based on an estimated weighting of $22 \%$ operable and $78 \%$ fixed windows ${ }^{1}$, a baseline window U-factor and solar heat gain coefficient are determined to match the fenestration performance criteria outlined in Tables 5.5.1 through 5.5.8 of the Standard, by climate.

Although window requirements in the Standard are defined by the overall properties of U-factor and SHGC, EnergyPlus requires that the thermal/optical properties be defined for the window assembly layer by layer. It is a challenge to develop hypothetical EnergyPlus window construction to match the specified U-factor and SHGC requirements outlined in Standard 90.1-2004. To overcome this challenge, a simplified strategy was used to find the closest match of a window construction in the EnergyPlus window library for given U and SHGC values. In the matching process, a close match to the SHGC value is regarded as a more important criterion for climate Zones 1-3, where cooling load is a major consideration. On the other hand, a close match to the U-value is a more important criterion for climate Zones 4 through 8 , where heating load is the major consideration. Because only a close match can be found, there is a minor deviation between the modeled $U$ and SHGC values and the target values. Table 4.1 lists the target and actual performance for the selected window constructions in the baseline case. The effects of window frame and dividers are not modeled explicitly.

In addition to U-factor and SHGC, the simulation accounts for visible light transmittance (VLT). VLT has no direct impact on building loads or energy consumption and there is no prescriptive requirement for VLT in Standard 90.1. However, VLT will impact the performance of daylighting systems. For the baseline fenestration, VLT values are simply based on the window construction in the EnergyPlus window library that meet the desired U-factor and SHGC.

\footnotetext{
${ }^{1}$ ASHRAE SSPC 90.1 Envelope Subcommittee provided the estimated weighting factor based on the Ducker Fenestration Market Data.
} 
Table 4.1. Fenestration U-Factor and SHGC Value for the Baseline Model

\begin{tabular}{|c|c|c|c|c|c|c|c|c|}
\hline \multirow[b]{3}{*}{$\begin{array}{l}\text { Climate } \\
\text { Zone }\end{array}$} & \multicolumn{4}{|c|}{ Nonresidential } & \multicolumn{4}{|c|}{ Residential } \\
\hline & \multicolumn{2}{|c|}{ Target Values } & \multicolumn{2}{|c|}{ Actual Values } & \multicolumn{2}{|c|}{ Target Values } & \multicolumn{2}{|c|}{ Actual Values } \\
\hline & $\begin{array}{c}\text { U-Factor } \\
\mathrm{Btu} /{ }^{\circ} \mathrm{F} \cdot \mathrm{h} \cdot \mathrm{ft}^{2} \\
\left(\mathrm{~W} / \mathrm{K} \cdot \mathrm{m}^{2}\right)\end{array}$ & SHGC & $\begin{array}{c}\text { U-Factor } \\
\mathrm{Btu} /{ }^{\circ} \mathrm{F} \cdot \mathrm{h} \cdot \mathrm{ft}^{2} \\
\left(\mathrm{~W} / \mathrm{K} \cdot \mathrm{m}^{2}\right)\end{array}$ & SHGC & $\begin{array}{c}\text { U-Factor } \\
\mathrm{Btu} /{ }^{\circ} \mathrm{F} \cdot \mathrm{h} \cdot \mathrm{ft}^{2} \\
\left(\mathrm{~W} / \mathrm{K} \cdot \mathrm{m}^{2}\right)\end{array}$ & SHGC & $\begin{array}{c}\text { U-Factor } \\
\mathrm{Btu} /{ }^{\circ} \mathrm{F} \cdot \mathrm{h} \cdot \mathrm{ft}^{2} \\
\left(\mathrm{~W} / \mathrm{K} \cdot \mathrm{m}^{2}\right)\end{array}$ & SHGC \\
\hline 1 & $\begin{array}{c}1.23 \\
(6.98)\end{array}$ & 0.25 & $\begin{array}{c}1.08 \\
(6.13)\end{array}$ & 0.28 & $\begin{array}{c}1.23 \\
(6.98)\end{array}$ & 0.25 & $\begin{array}{c}1.08 \\
(6.13)\end{array}$ & 0.28 \\
\hline 2 & $\begin{array}{c}1.23 \\
(6.98)\end{array}$ & 0.25 & $\begin{array}{c}1.08 \\
(6.13)\end{array}$ & 0.28 & $\begin{array}{c}1.23 \\
(6.98)\end{array}$ & 0.25 & $\begin{array}{c}1.08 \\
(6.13)\end{array}$ & 0.28 \\
\hline $3 \mathrm{~A}, 3 \mathrm{~B}$ & $\begin{array}{c}0.59 \\
(3.35)\end{array}$ & 0.25 & $\begin{array}{c}0.51 \\
(2.90)\end{array}$ & 0.28 & $\begin{array}{c}0.59 \\
(3.35)\end{array}$ & 0.39 & $\begin{array}{c}0.55 \\
(3.12)\end{array}$ & 0.43 \\
\hline $3 \mathrm{C}$ & $\begin{array}{c}1.23 \\
(6.98)\end{array}$ & 0.39 & $\begin{array}{c}0.96 \\
(5.45)\end{array}$ & 0.37 & $\begin{array}{c}1.23 \\
(6.98)\end{array}$ & 0.61 & $\begin{array}{c}1.08 \\
(6.13)\end{array}$ & 0.61 \\
\hline 4 & $\begin{array}{c}0.59 \\
(3.35)\end{array}$ & 0.39 & $\begin{array}{c}0.55 \\
(3.12)\end{array}$ & 0.43 & $\begin{array}{c}0.59 \\
(3.35)\end{array}$ & 0.39 & $\begin{array}{c}0.55 \\
(3.12)\end{array}$ & 0.43 \\
\hline 5 & $\begin{array}{c}0.59 \\
(3.35)\end{array}$ & 0.39 & $\begin{array}{c}0.55 \\
(3.12)\end{array}$ & 0.43 & $\begin{array}{c}0.59 \\
(3.35)\end{array}$ & 0.39 & $\begin{array}{c}0.55 \\
(3.12)\end{array}$ & 0.43 \\
\hline 6 & $\begin{array}{c}0.59 \\
(3.350\end{array}$ & 0.39 & $\begin{array}{c}0.55 \\
(3.12)\end{array}$ & 0.43 & $\begin{array}{c}0.59 \\
(3.35)\end{array}$ & 0.39 & $\begin{array}{c}0.55 \\
(3.12)\end{array}$ & 0.43 \\
\hline 7 & $\begin{array}{c}0.59 \\
(3.35)\end{array}$ & 0.49 & $\begin{array}{c}0.55 \\
(3.12)\end{array}$ & 0.50 & $\begin{array}{c}0.59 \\
(3.35)\end{array}$ & 0.49 & $\begin{array}{c}0.55 \\
(3.12)\end{array}$ & 0.50 \\
\hline 8 & $\begin{array}{c}0.46 \\
(2.61)\end{array}$ & 0.45 & $\begin{array}{c}0.48 \\
(2.73)\end{array}$ & 0.47 & $\begin{array}{c}0.46 \\
(2.61)\end{array}$ & 0.45 & $\begin{array}{c}0.48 \\
(2.73)\end{array}$ & 0.47 \\
\hline
\end{tabular}

\subsection{Internal Loads}

Building internal loads include heat generated from occupants, lights, and miscellaneous equipment (plug loads such as computers, printers, small beverage machines, etc.). Modeling the energy impacts of the building internal loads using the EnergyPlus simulation program requires assumptions about the building internal load intensity and operation schedules that diversify the peak load.

Typically, the internal loads are represented by peak occupancy density for occupancy thermal load (in person $/ \mathrm{ft}^{2}$ ) and peak power density (in $\mathrm{W} / \mathrm{ft}^{2}$ ) for lighting and plug loads and a schedule that describes the hourly magnitude (usually given in terms of fractions of the peak). These fractions multiplied by the peak load density give the actual load density for each hour. Because the lodging buildings usually have multiple space types with different functions, space-by-space method was used to determine the peak internal loads densities and load schedules. In the following section, the modeling assumptions for people loads, interior lighting, exterior lighting, and plug loads are documented.

Highway lodging buildings are generally occupied 24 hours a day, 365 days a year. However, the building contains a variety of space types with differing usage patterns. The building model includes discrete schedules for guest rooms, lobby, front desk and office areas, meeting rooms, an exercise room, employee lounge, and a laundry room. The guest rooms, lobby and office are assumed to be occupied around the clock, while the meeting room, laundry room, exercise room, and employee lounge are unoccupied at night and early morning hours. Separate schedules were developed for rented and unrented guest rooms. The baseline internal load schedules for the guest rooms were adapted from Screening Analysis for EPACT-Covered Commercial HVAC and Water-Heating Equipment (DOE 2000). Schedules for lighting and plug loads were matched to occupancy schedules. The other schedules were derived 
based on the AEDG-HL project committee's inputs. The occupancy schedules were assumed to be the same for baseline buildings and advanced buildings. To model energy-efficient control technologies for lighting and plug loads, the lighting and plug loads schedules for some of the spaces (such as guest rooms, office, etc.) were assumed to be different for baseline buildings and advanced buildings. Figure 4.1 illustrates the typical weekday schedules for occupancy, lighting, and appliance and equipment as simulated in EnergyPlus. Appendix A provides detailed schedules for all space types.

\section{Guestroom Weekday Schedules}

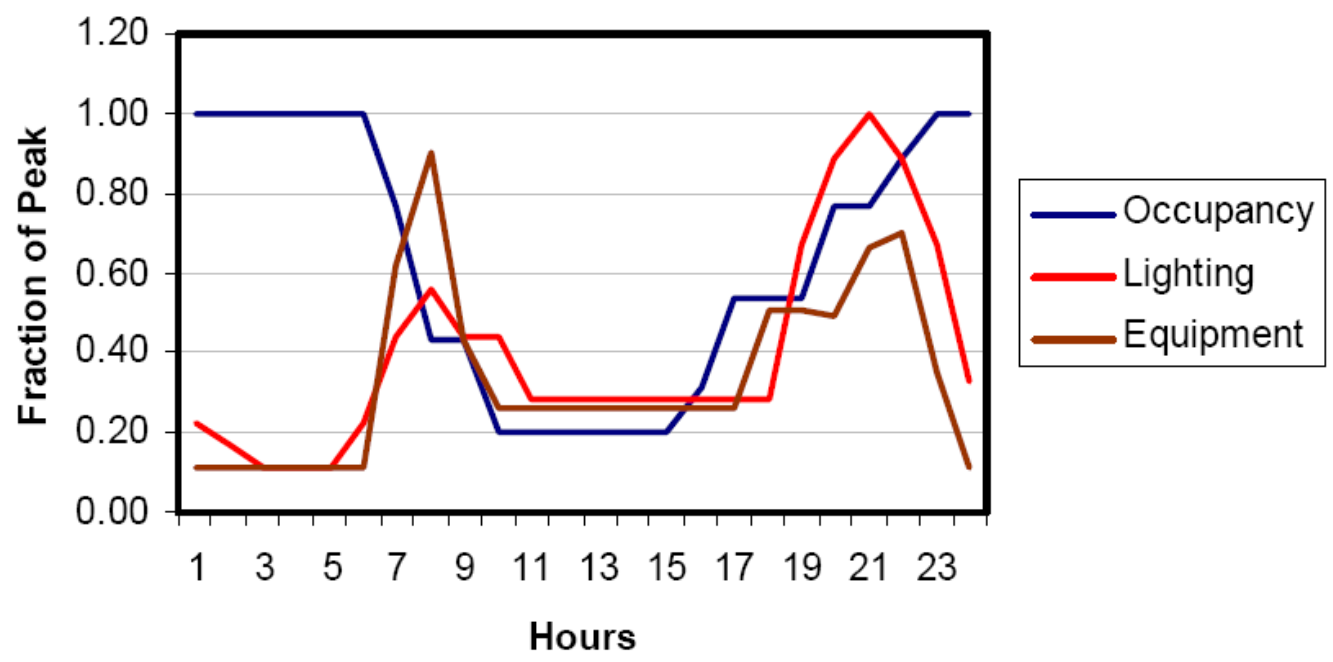

Figure 4.1. Highway Lodging Guestroom Typical Weekday Schedules

\subsubsection{People}

According to the 2008 Lodging Industry Profile report (AHLA 2008), the average occupancy rate was $63.1 \%$ for the lodging industry in 2007 . Therefore, the highway lodging prototype was modeled that $65 \%$ of the guest rooms were rented throughout the year; the Excel random number generator was used to randomly assign $35 \%$ of the guest rooms to be vacant. The report also suggests that there is usually one person in a business room, two persons in a leisure room, 44\% customers traveled for business and 56\% customers traveled for leisure. Consequently, it was assumed that there were on average 1.5 persons in each of those rented rooms. The value of the peak occupancy for office space, lobby, lounge, meeting room, and exercise room is based on occupant densities listed in ASHRAE Standard 62.1-2004 (ANSI/ASHRAE 2004). Standard 62.1-2004 Table 6-1 provides the estimations of default occupancy density for different space types in lodging buildings. Peak occupancy for the laundry was derived from ASHRAE Standard 62-1999 (ANSI/ASHRAE 1999), because no value was given for that space type in the 2004 version of the Standard. Table 4.2 gives peak occupant density for the various space types in the highway lodging building model.

For all spaces except for the exercise room, it was assumed that the total heat gain is $450 \mathrm{Btu} / \mathrm{h}$ $(132 \mathrm{~W})$ per person, including $250 \mathrm{Btu} / \mathrm{h}(73.3 \mathrm{~W})$ sensible heat gain and $200 \mathrm{Btu} / \mathrm{h}(58.6 \mathrm{~W})$ latent heat gain. For the exercise room, the total heat gain is assumed to be $1,450 \mathrm{Btu} / \mathrm{h}(425 \mathrm{~W})$ per person, including $580 \mathrm{Btu} / \mathrm{h}(170 \mathrm{~W})$ sensible heat gain and $870 \mathrm{Btu} / \mathrm{h}(255 \mathrm{~W})$ latent heat gain. These values are 
based on the expected degree of activity, i.e., standing, light work and walking for the office, and "heavy work" for the exercise room. The values were derived from Table 1 of Chapter 30 in the ASHRAE 2005 Fundamentals Handbook (ASHRAE 2005). This also assumes that the occupant activity levels do not vary with climate.

Table 4.2. Peak Occupancy Density by Space Type

\begin{tabular}{lll}
\hline \multicolumn{1}{c}{ Space Type } & \multicolumn{1}{c}{ Occupant Load } & \multicolumn{1}{c}{ Source } \\
\hline Guest room & 1.5 persons per room & $\begin{array}{l}\text { 2008 Lodging Industry Profile and } \\
\text { AEDG-HL Committee's Inputs }\end{array}$ \\
Office & $200 \mathrm{ft}^{2} /$ person $\left(18.6 \mathrm{~m}^{2} /\right.$ person $)$ & ASHRAE Standard $62.1-2004$ \\
Lobby & $33 \mathrm{ft}^{2} /$ person $\left(2.8 \mathrm{~m}^{2} /\right.$ person $)$ & ASHRAE Standard $62.1-2004$ \\
Lounge & $20 \mathrm{ft}^{2} /$ person $\left(1.9 \mathrm{~m} \mathrm{~m}^{2} /\right.$ person $)$ & ASHRAE Standard $62.1-2004$ \\
Meeting room & $20 \mathrm{ft}^{2} /$ person $\left(1.9 \mathrm{~m} \mathrm{~m}^{2} /\right.$ person $)$ & ASHRAE Standard $62.1-2004$ \\
Exercise room & $25 \mathrm{ft}^{2} /$ person $\left(2.3 \mathrm{~m}^{2} /\right.$ person $)$ & ASHRAE Standard $62.1-2004$ \\
Laundry room & $100 \mathrm{ft}^{2} /$ person $\left(9.3 \mathrm{~m}^{2} /\right.$ person $)$ & ASHRAE Standard $62-1999$ \\
\hline
\end{tabular}

\subsubsection{Interior Lighting}

Lighting energy use can vary greatly depending on the nature of the spaces served and the type of lighting fixtures used in the building. Lighting for the public, back of house, and office areas many times have light sources operating 24 hours a day, unless control measures are incorporated to minimize use. Guest room lighting will normally be under the control of the guest when occupied, and set to minimal levels by housekeeping staff when the room is not occupied.

The EnergyPlus program allows the user to specify information about the electric lighting system in each zone, including design power level and operation schedule, and how the heat from lights is distributed thermally. The baseline lighting system is assumed to be a system that just meets the lighting power density requirements of the space-by-space method described in Standard 90.1-2004, Table 9.6.1. The baseline interior lighting power for each space type in the highway lodging building is shown in Table 4.3. The interior lighting power densities (LPD) in $\mathrm{W} / \mathrm{ft}^{2}\left(\mathrm{~W} / \mathrm{m}^{2}\right)$ were used as the inputs to the baseline building EnergyPlus model.

Standard 90.1 includes various mandatory interior lighting control requirements including buildingwide automatic shutoff (for spaces not occupied 24 hours per day) and occupancy sensor control in the conference room, meeting room, and employee lounge. The Standard also requires a master control device at the entrance of each guest room that controls all permanently installed luminaries and switched receptacles. These mandatory controls are not explicitly simulated in the EnergyPlus model, as the lighting diversity schedule is assumed to reflect the inclusion of these mandatory controls. The typical baseline lighting operation schedules for each space type are documented in Appendix A. 
Table 4.3. Baseline Interior Lighting Power Density by Space Type

\begin{tabular}{lc}
\hline Space Type & $\begin{array}{c}\text { Standard } 90.1-2004 \\
\mathrm{~W} / \mathrm{ft}^{2}\left(\mathrm{~W} / \mathrm{m}^{2}\right)\end{array}$ \\
\hline Guest room & $1.1(11.84)$ \\
Corridor & $0.5(5.38)$ \\
Lobby & $1.1(11.84)$ \\
Stairs & $0.6(6.46)$ \\
Office & $1.1(11.84)$ \\
Laundry & $0.6(6.46)$ \\
Meeting room & $1.3(14.00)$ \\
Exercise room & $0.9(9.69)$ \\
Storage & $0.8(8.61)$ \\
Employee lounge & $1.2(12.92)$ \\
Restroom & $0.9(9.69)$ \\
Mechanical room & $1.5(16.15)$ \\
\hline
\end{tabular}

\subsubsection{Exterior Lighting}

Energy use for exterior lighting is significant in lodging buildings and is included as part of the total building energy use. Table 9.4.5 of Standard 90.1-2004 specifies permitted maximum lighting power densities for building exteriors (e.g., parking areas, building grounds, building façade, entrance, etc.). In addition, an unrestricted adder (base site allowance) of $5 \%$ of the total connected load is allowed. Those values were used for the baseline building models as shown in Table 4.4. The areas shown in Table 4.4 were derived from the Hampton Inn Prototype plans.

Standard 90.1-2004 requires that exterior lighting shall have automatic controls capable of turning exterior lighting off when sufficient daylight is available or when lighting is not required (i.e., during nighttime hours). Use of an astronomical time switch or a photo-sensor is required for all exterior lighting. The baseline models simulated the use of an astronomical time switch.

Table 4.4. Baseline Exterior Lighting Power

\begin{tabular}{lccr}
\hline & $\begin{array}{c}\text { Area } \\
\mathrm{ft}^{2}\left(\mathrm{~m}^{2}\right)\end{array}$ & $\begin{array}{c}\text { LPD } \\
\mathrm{W} / \mathrm{ft}^{2} \text { or W/lf } \\
\left(\mathrm{W} / \mathrm{m}^{2} \text { or W/m}\right)\end{array}$ & $\begin{array}{c}\text { Total Power } \\
(\mathrm{W})\end{array}$ \\
\hline Parking & $39,800(3698)$ & $0.15(1.61)$ & 5,970 \\
Walkway [10 ft $(3 \mathrm{~m})$ wide or greater] & $1,020(310)$ & $0.2(0.65)$ & 204 \\
Canopy & $1,315(122)$ & $1.25(13.45)$ & 1,644 \\
Pool & $2,155(200)$ & $0.2(2.15)$ & 431 \\
Facade & $20,800(1932)$ & $0.2(2.15)$ & 4,160 \\
Subtotal & & & 12,409 \\
Base site allowance $(5 \%)$ & & & 620 \\
Total & & & 13,029 \\
\hline
\end{tabular}




\subsubsection{Miscellaneous Equipment}

Commercial buildings generally have substantial plug loads, which increase the electrical energy use of the building. Plug loads also contribute to the cooling load of the building, while offsetting the heating load. Plug loads in highway lodging represent electrical appliances operated in the conditioned space, such as TV, microwave, coffee maker, computers, hair dryers, refrigerators, irons, and other equipment plugged into electrical outlets. In addition, lodging buildings have significant energy use consumed by laundry equipment. In some cases, miscellaneous loads might be directly wired into the electrical circuit (e.g., small motors).

The peak power densities of miscellaneous loads in the highway lodging building energy model were calculated by adding the peak power of all typically used appliances in that space and multiplying the peak power by the appliance usage diversity factor. The peak power for common appliances and office equipment in the highway lodging building was obtained from several sources, including the 2005 ASHRAE Handbook: Fundamentals, ENERGY STAR website, web search, etc. Table 4.5 summarizes the baseline plug load peak density assumption for each space type input in the EnergyPlus model. The detailed calculations for miscellaneous equipment loads in guest rooms and the laundry area are described in Section 4.2.4.1. Appendix A provides detailed equipment schedules for each space type.

Table 4.5. Baseline Plug Load Peak Power Density by Space Type

\begin{tabular}{lc}
\hline \multicolumn{1}{c}{ Space Type } & $\begin{array}{c}\text { Plug Load Peak Density } \\
\mathrm{W} / \mathrm{ft}^{2}\left(\mathrm{~W} / \mathrm{m}^{2}\right)\end{array}$ \\
\hline Guest room & $1.01(10.82)$ \\
Lobby & $2.59(27.90)$ \\
Office & $1.24(13.37)$ \\
Meeting room & $0.57(6.18)$ \\
Exercise room & $1.77(19.05)$ \\
Employee lounge & $2.00(21.51)$ \\
Corridor/stairs/restroom/ & $0(0)$ \\
mechanical room/storage & \\
\hline
\end{tabular}

The electricity consumption of the elevators in the highway lodging prototype was derived based on a study by Sachs (2005). The study suggests that a conventional light-loaded low-rise hydraulic elevator doing 100,000 starts (door openings) consumes 1,900 kWh per year. Therefore, in the highway lodging prototype, the elevators consume about $8,322 \mathrm{kWh}$ per year, assuming that there are 100 persons in the building and each person has six runs per day.

\subsubsection{Guest Room and Laundry Room Miscellaneous Equipment}

This section documents how the plug load power densities were derived for guest rooms and the laundry room. To determine the plug load density in guest room, a break-down plug load calculation was developed in accordance with recommended heat gains from various appliances and office equipment (ASHRAE 2007, Roberson et al. 2002). As shown in Table 4.6, the plug load density for guest rooms was calculated to be $1.01 \mathrm{~W} / \mathrm{ft}^{2}\left(10.82 \mathrm{~W} / \mathrm{m}^{2}\right)$. 
Table 4.6. Baseline Plug Load Density Calculations for Guest Rooms

\begin{tabular}{|c|c|c|c|c|c|c|c|}
\hline Equipment & Quantity & $\begin{array}{c}\text { Peak } \\
\text { Power } \\
(W)\end{array}$ & $\begin{array}{l}\text { Usage } \\
\text { Length } \\
\text { Fraction } \\
(\mathrm{min} / 60)\end{array}$ & $\begin{array}{l}\text { Quantity } \\
\text { Diversity }\end{array}$ & $\begin{array}{c}\text { Overall } \\
\text { Diversity }\end{array}$ & $\begin{array}{l}\text { Hourly } \\
\text { Power } \\
\text { (W) }\end{array}$ & Remarks \\
\hline $\begin{array}{l}\text { Compact } \\
\text { refrigerator }\end{array}$ & 1 & 42 & 1 & 1.00 & 1.00 & 42 & (a) \\
\hline TV & 1 & 95 & 1 & 0.75 & 0.75 & 56 & (b) \\
\hline Microwave & 1 & 400 & 0.08 & 0.25 & 0.02 & 8 & (c) \\
\hline Hair dryer & 1 & 1,500 & 0.17 & 0.25 & 0.04 & 63 & (d) \\
\hline Iron & 1 & 1,000 & 0.25 & 0.15 & 0.04 & 38 & (d) \\
\hline $\begin{array}{l}\text { Coffee } \\
\text { maker }\end{array}$ & 1 & 1,050 & 0.25 & 0.50 & 0.13 & 131 & (c) \\
\hline $\begin{array}{l}\text { Total } \\
\mathrm{W} / \mathrm{ft}^{2} \\
\left(\mathrm{~W} / \mathrm{m}^{2}\right)\end{array}$ & & & & & & $\begin{array}{c}1.01 \\
(10.82)\end{array}$ & \\
\hline
\end{tabular}

Notes:

(a) The average annual energy consumption is $365 \mathrm{kWh} /$ year for a typical ENERGY STAR compact refrigerator, based on the U.S. Environmental Protection Agency's estimate. (http://www.energystar.gov/)

(b) Data derived from ENERGY STAR TV Savings Calculator . (http://www.energystar.gov/)

(c) Data derived from the 2005 ASHRAE Handbook: Fundamentals Chapter 30 (ASHRAE 2005).

(d) Web search.

Laundering of bed linen and towels consumes significant amounts of energy in highway lodging buildings. Based on the lodging industry practice, industry averages for laundry usage are approximately $9 \mathrm{lb}(4.08 \mathrm{~kg})$ of laundry per room per day. Conventional commercial washers consume approximately 1.2 gallon $(4.5 \mathrm{~L})$ of hot water per pound of laundry. The retained water for the standard washer is approximately $87.5 \%$ of the dry weight of the laundry. The equipment in laundry room in the studied prototype consists of two $60 \mathrm{lb}(27.2 \mathrm{~kg})$ commercial washers and two $75 \mathrm{lb}(34.0 \mathrm{~kg})$ commercial gas dryers. Based on the research done by the AEDG-HL project committee, it was assumed that the conventional $60 \mathrm{lb}(27.2 \mathrm{~kg})$ commercial washer consumes $1.39 \mathrm{kWh} /$ cycle electricity, and the conventional $75 \mathrm{lb}(34.0 \mathrm{~kg})$ commercial gas dryer consumes $0.75 \mathrm{kWh} /$ cycle electricity. To remove the water from the laundry, the commercial gas dryer consumes 0.68 therm/cycle $(19.93 \mathrm{kWh} /$ cycle $)$ of gas for the prototype, as shown in Table 4.7. These energy consumption values are input into the EnergyPlus models. 
Table 4.7. Baseline Laundry Equipment Gas Consumption

\begin{tabular}{|c|c|c|c|c|c|c|c|c|}
\hline \multirow[b]{2}{*}{$\begin{array}{l}\text { Washer } \\
\text { Type }\end{array}$} & \multirow[b]{2}{*}{$\begin{array}{l}\text { No. of } \\
\text { Rooms }\end{array}$} & \multirow{2}{*}{$\begin{array}{l}\text { Laundry } \\
\text { Load } \\
\text { lb/room } \\
\text { (kg/room) }\end{array}$} & \multicolumn{2}{|c|}{$\begin{array}{c}\text { Water Use per Pound of } \\
\text { Laundry }\end{array}$} & \multicolumn{4}{|c|}{ Gas Use } \\
\hline & & & $\begin{array}{c}\text { Total Water } \\
\text { gallon/lb } \\
\text { (L/kg) }\end{array}$ & $\begin{array}{c}\text { Hot Water } \\
\text { gallon/lb } \\
(\mathrm{L} / \mathrm{kg})\end{array}$ & $\begin{array}{c}\% \\
\text { Retained } \\
\text { Water } \\
\text { (g's) }\end{array}$ & $\begin{array}{c}\text { Annual } \\
\text { Water } \\
\text { Removed } \\
\text { lb (kg) } \\
\end{array}$ & $\begin{array}{c}\text { Annual } \\
\text { Gas Use } \\
\text { therms } \\
(\mathrm{MW}) \\
\end{array}$ & $\begin{array}{c}\text { Gas Use } \\
\text { therms/cycle } \\
\text { (kWh/cycle) }\end{array}$ \\
\hline Standard & 77 & $\begin{array}{c}9 \\
(4.08)\end{array}$ & $\begin{array}{c}3 \\
(25.03)\end{array}$ & $\begin{array}{c}1.2 \\
(10.01)\end{array}$ & $87.5 \%$ & $\begin{array}{c}221,327 \\
(100,393)\end{array}$ & $\begin{array}{l}3,995 \\
(117)\end{array}$ & $\begin{array}{c}0.68 \\
(19.93)\end{array}$ \\
\hline
\end{tabular}

\subsection{HVAC Systems}

This section describes the development of the typical heating and cooling systems used in highway lodging buildings, thermal zone configuration as well as assumptions of the baseline HVAC system including operation schedule and heating and cooling set points, equipment sizing and efficiency, outdoor air system, etc.

\subsubsection{HVAC System Type}

In the 2003 CBECS, the main heating and cooling equipment is characterized by variables "MAINHT8" (the values are "Furnaces that heat air directly," "Packaged heating units," "Boilers inside the building," etc.), and "MAINCL8" (the values are "Packaged air conditioning units," "Residential type central air conditioners," "Individual room air conditioners," etc.), respectively. The data report that for hotel/motel buildings that have less than 80 rooms, $42 \%$ of the buildings use individual space heaters as the main heating equipment (Figure 4.2 ) and $49 \%$ of the buildings use individual room air conditioner as the main cooling equipment (Figure 4.3).

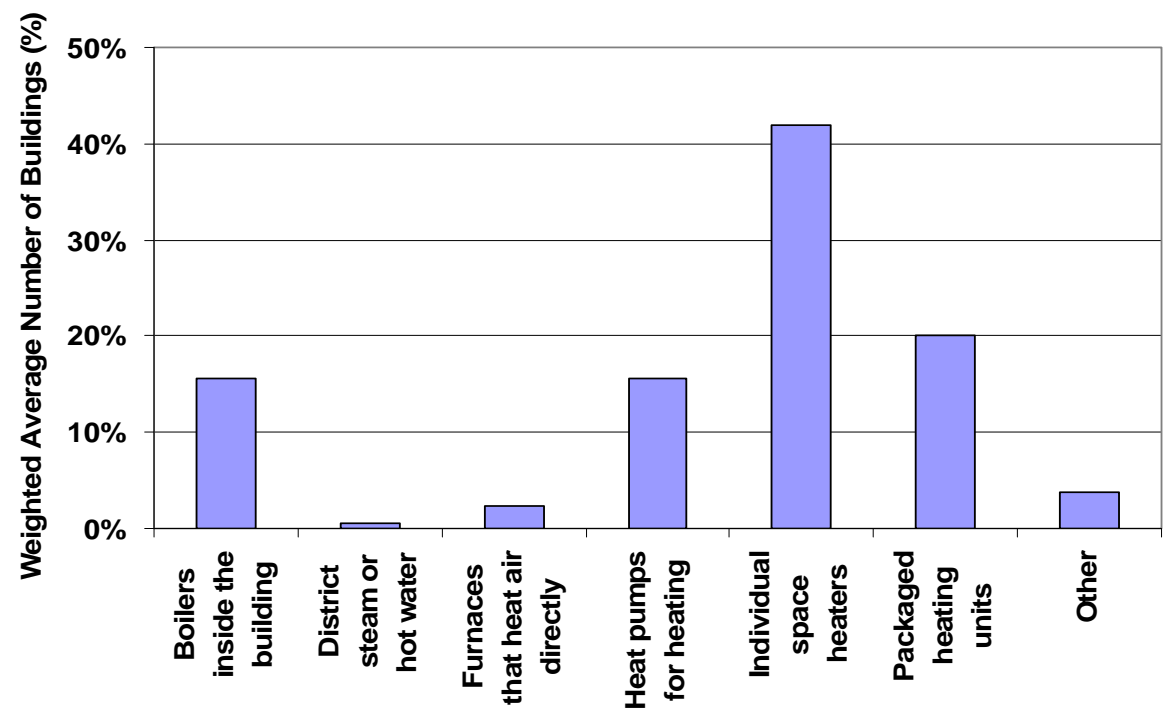

Figure 4.2. Main Heating Equipment Categories in 2003 CBECS (for motel/hotels with less than 80 rooms) 


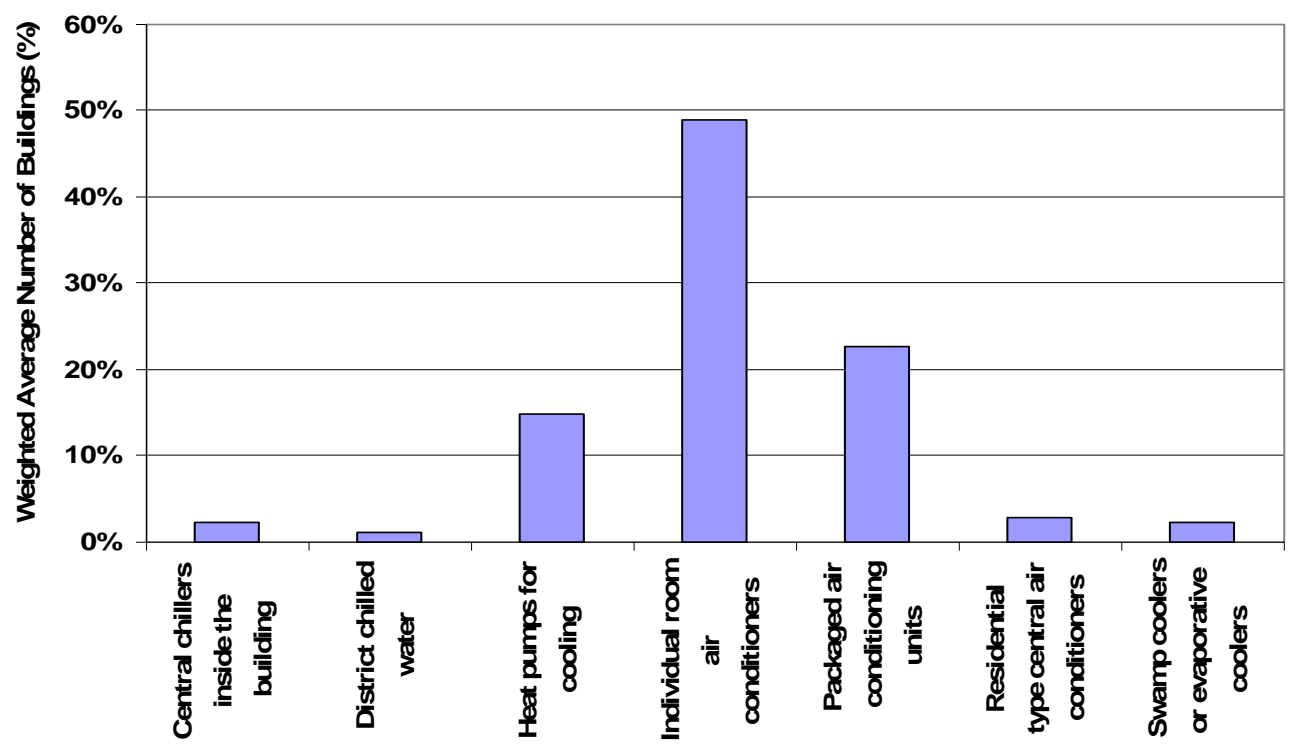

Figure 4.3. Main Cooling Equipment Categories in 2003 CBECS (for motel/hotels with less than 80 rooms)

Unfortunately, not all the 2003 CBECS responses regarding equipment categories are mutually exclusive, particularly in the categories of packaged heating units, individual space heaters, packaged air conditioning units, individual room air conditioners, and heat pumps; the sum of the percentage of which is $78 \%$ for the main heating equipment and $87 \%$ for the main cooling equipment for the hotel $/$ motel buildings that have less than 80 rooms. Based on the inputs from the lodging industry experts, the most typical heating and cooling system used in guest rooms in highway lodging is packaged terminal air conditioner (PTAC); and the typical heating and cooling system used in public spaces is a split air conditioner system. Both of these systems can be categorized as packaged heating units (or individual space heaters for heating) and packaged air conditioning units (or individual room air conditioner for cooling), thus consistent with the CBECS statistic data. Review of the $\mathrm{NC}^{3}$ database also suggests that PTACs are commonly used in the guests' rooms and split system is commonly used in public spaces for small hotels and motels.

Furthermore, the Ducker's PTAC market research report (Ducker Worldwide 2001) reveals that hotels/motels are the biggest end users of PTAC and packaged terminal heat pump (PTHP), accounting for $70 \%$ of the PTAC and PTHP market. More-detailed market data shows that among the four major sizes of PTAC and PTHP, (7 kBtu/h, $9 \mathrm{kBtu} / \mathrm{h}, 12 \mathrm{kBtu} / \mathrm{h}$, and $15 \mathrm{kBtu} / \mathrm{h})$, the PTAC and PTHP of 9 $\mathrm{kBtu} / \mathrm{h}$ capacity accounts for approximately $50 \%$ of the U.S. PTAC and PTHP market in year 2000.

As summarized in Table 4.8, it was assumed that in the baseline building the guest room was served by a PTAC with electric resistance heat with $9 \mathrm{kBtu} / \mathrm{h}(2.6 \mathrm{~kW})$ cooling capacity. To serve the common areas, split system air conditioning units with gas furnace heating were selected. Guest rooms typically use one PTAC per room to allow individual on-off and thermostatic control. It was also assumed that unit heaters were used to condition semi-heated spaces, including the mechanical room and stairs. Outdoor ventilation air is supplied to the guest rooms by a central make-up air unit (MAU) with direct expansion 
(DX) coil and gas furnace. Each guest room is served by a central toilet exhaust system that operates continuously.

Table 4.8. Baseline Building HVAC Systems

\begin{tabular}{ll}
\hline \multicolumn{1}{c}{ Building Area } & \multicolumn{1}{c}{ HVAC System Type } \\
\hline Guest rooms & $\begin{array}{l}\text { PTAC with electric resistance, MAU, } \\
\text { and central toilet exhaust system }\end{array}$ \\
Mechanical room and stairs & Unit heaters \\
All other public spaces & Split air conditioner \\
\hline
\end{tabular}

\subsubsection{Thermal Zoning}

The first floor of the highway lodging building is divided into 19 thermal zones. There are individual zones for each of the common space types (lobby, office, meeting room, laundry room, exercise room, lounge, corridor, stair, and storage). To reduce the EnergyPlus simulation time, some of the guest rooms that have similar thermal behavior were combined into one thermal zone. Zoning for the second through fourth floors is identical, and consists of 16 zones on each floor. Similar to the first floor, there are individual zones for stairways and storage areas but similar guest rooms are combined into a single thermal zone. Each thermal zone is served by a single zone HVAC system in the models. Figure 4.4 and Figure 4.5 show zoning maps of the first and second through fourth floors, respectively. 


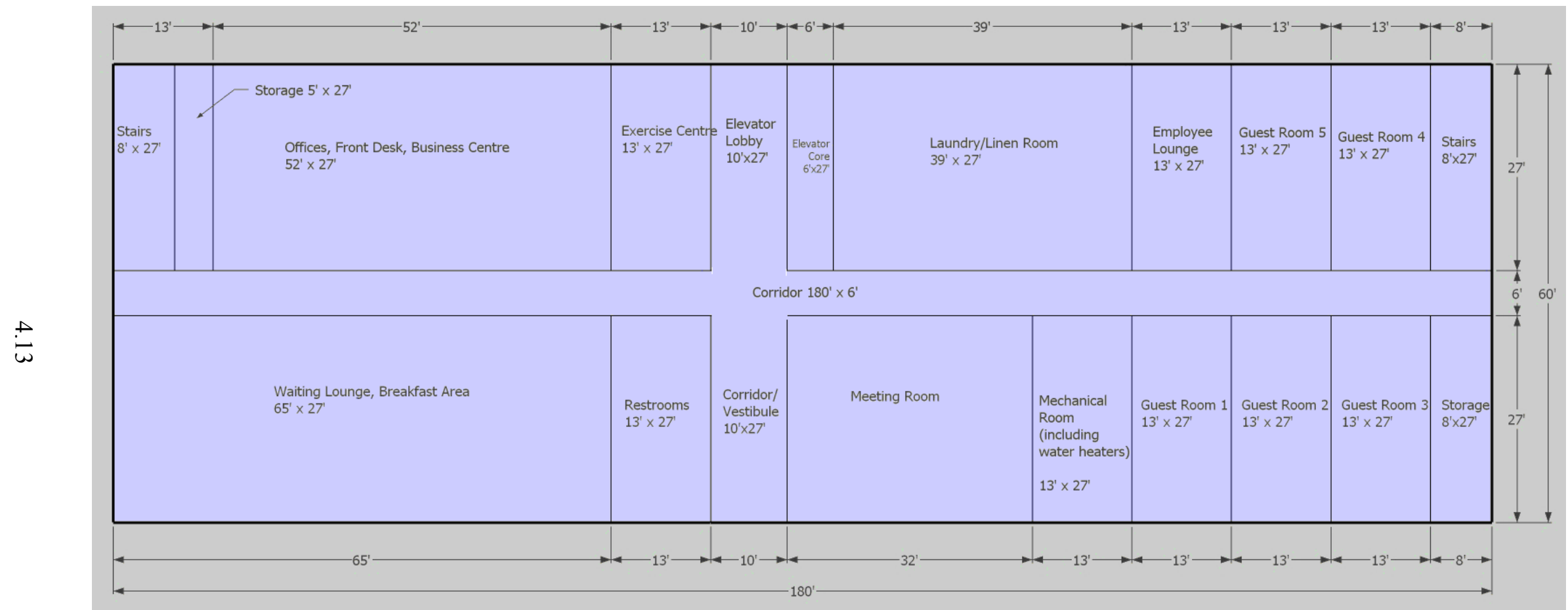

Figure 4.4. HVAC Zoning Map - First Floor 


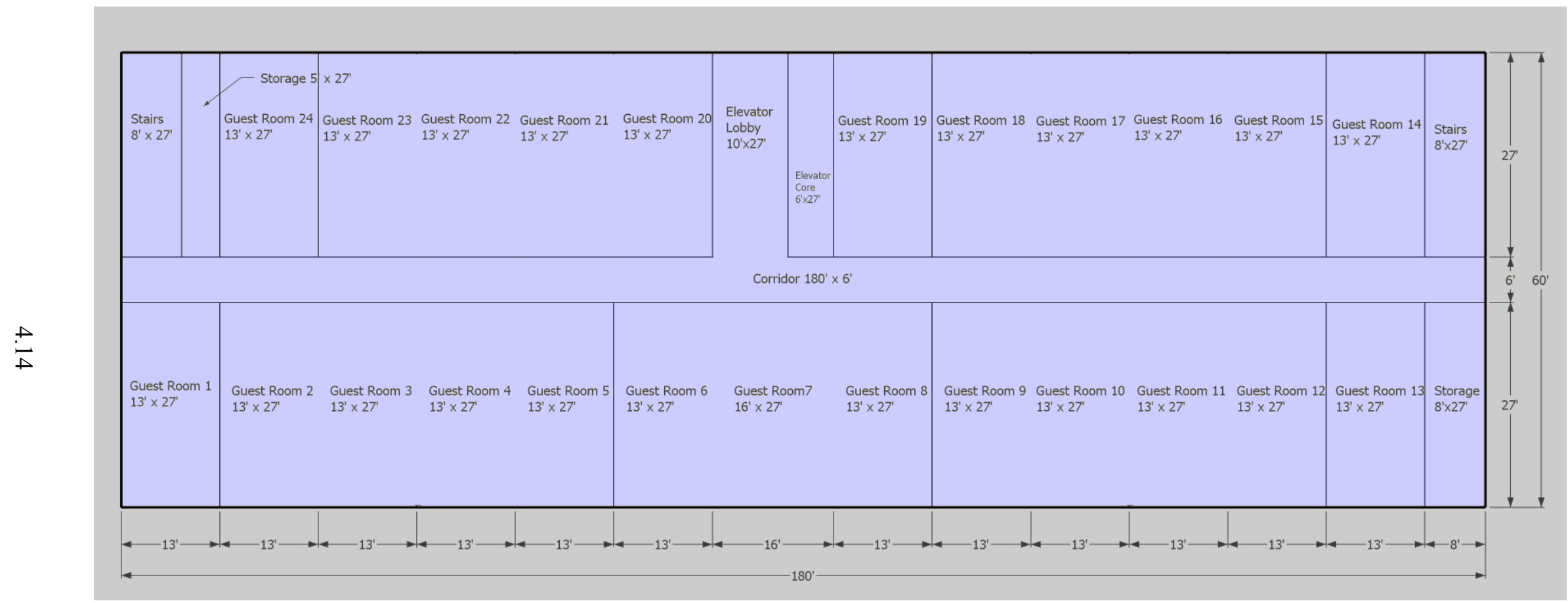

Figure 4.5. HVAC Zoning Map - Typical Floor 


\subsubsection{Building HVAC Operating Schedules}

In the baseline building, HVAC systems are assumed to run continuously in the rented guest rooms and public spaces. For the unrented guest rooms, it is assumed that the HVAC systems cycle on and off to maintain the setback thermostat temperature.

\subsubsection{Heating and Cooling Thermostat Setpoint}

Based on the lodging industry practice, rented guest rooms were assumed to maintain $70^{\circ} \mathrm{F}\left(21.1^{\circ} \mathrm{C}\right)$ for both heating and cooling year around. For vacant guest rooms, thermostat setback control was assumed with a $4^{\circ} \mathrm{F}\left(2.2^{\circ} \mathrm{C}\right)$ temperature setback to $66^{\circ} \mathrm{F}\left(18.9^{\circ} \mathrm{C}\right)$ for heating and $74^{\circ} \mathrm{F}\left(23.3^{\circ} \mathrm{C}\right)$ for cooling. The public spaces are maintained at $70^{\circ} \mathrm{F}\left(21.1^{\circ} \mathrm{C}\right)$ heating setpoint and $75^{\circ} \mathrm{F}\left(23.9^{\circ} \mathrm{C}\right)$ cooling setpoint year around. The semi-heated mechanical room and stairs are heated to $45^{\circ} \mathrm{F}\left(7.2^{\circ} \mathrm{C}\right)$.

\subsubsection{HVAC Equipment Sizing}

Equipment sizing refers to the method used to determine cooling and heating capacities of the mechanical equipment, and the supply air flow rate through the fans. The baseline systems were modeled in EnergyPlus with each thermal zone served by one PTAC unit or one split system air-conditioner. A single make-up-air unit provides ventilation to all of the guest rooms.

To reduce the EnergyPlus simulation time, some of the guest rooms that have similar thermal behavior were combined into one thermal zone. This resulted in a total of 67 thermal zones for the building, as described in Section 4.3.2. The cooling capacity of the PTAC unit serving a specific thermal zone was calculated by multiplying the actual capacity of the most common size PTAC $(9 \mathrm{kBtu} / \mathrm{h}, 2.6 \mathrm{~kW})$ by the number of guest rooms in that thermal zone. The heating capacity of the electric resistance was auto-sized in the models to meet the guest room heating loads.

For the DX cooling coils and the furnaces in the split air-conditioner unit, the design day method was used to auto-size the cooling capacity and the heating capacity. When using the design day simulation method, two separate design day inputs are specified, one for heating and one for cooling. The program determines the design peak loads by simulating the buildings for a 24-hour period on each of the design days. The design peak loads are then used by the subprogram for sizing HVAC equipment. This study used the design-day method primarily for two reasons: 1) it is general practice for designers to choose the design-day method for sizing the HVAC equipment, and 2) using design-day method will prevent equipment over-sizing to meet the extreme peak weather conditions occurring for a very short period of time during a year. The design-day data for all 16 climate locations were developed based on the "weather data" contained in the 2005 ASHRAE Handbook: Fundamentals (ASHRAE 2005). In this data set, we used the annual heating design condition based on annual percentiles of $99.6 \%$ and the annual cooling design condition based on annual percentiles of $0.4 \%$. The internal loads (occupancy, lights, and plug loads) were scheduled as zero on the heating design day, and at a maximum level on the cooling design day. A 1.2 sizing factor was applied to all auto-sized heating and cooling capacities and air flow rates. 


\subsubsection{HVAC Equipment Efficiency}

Standard 90.1-2004 specifies HVAC equipment efficiency based on heating and cooling capacities. For split system and single packaged equipment with cooling capacities less than $65,000 \mathrm{Btu} / \mathrm{h}$ $(19,045 \mathrm{~W})$, efficiency is rated by seasonal energy efficiency ratio (SEER), which represents an average efficiency throughout the year. SEER is defined as the total cooling output of an air conditioner during its normal annual usage period for cooling (in Btu) divided by the total electric energy during the same period (in Wh). Larger split system and single packaged equipment and PTACs are rated by energy efficiency ratio (EER), which represents efficiency at a particular design condition, and is defined as the ratio of net cooling capacity in Btu/h to total rate of electric input in Watts at rated conditions.

In EnergyPlus, the efficiency of DX cooling systems is indicated by entering a coefficient of performance (COP), which is defined as the cooling power output in Watts divided by the electrical power input in Watts determined at the same environmental conditions as the EER. However, unlike EER, the COP input in EnergyPlus does not include the rated power consumption of the supply air fan, so an adjustment to the EER is needed to remove the effect of the indoor fan energy. For equipment rated by SEER, a conversion from SEER to EER is also required (Wassmer and Brandemuehl 2006). The input for COP in EnergyPlus is determined by the following equations.

$$
\begin{gathered}
E E R=-0.0182 \times S E E R^{2}+1.1088 \times S E E R \\
C O P=(E E R / 3.413+R) /(1-R)
\end{gathered}
$$

where $\quad \mathrm{R}$ is the ratio of supply fan power to total equipment power at the AHRI rating condition.

For split and single package air conditioners, typical values for fan power ratio $(\mathrm{R})$ vary between about 0.05 to 0.17 depending on specific product design choices. For this analysis, we assume a ratio of 0.12 as being representative of the broad class of products (PNNL 2004). This assumption is also consistent with the fan power calculated based on Equation (4.3) as descried in Section 4.3.7. Table 4.9 lists the efficiency requirements for the split system units from Table 6.8.1A in Standard 90.1-2004, and the calculated COP for input in the EnergyPlus model. In this highway lodging prototype, the capacities of the split air conditioners and the MAU are less than $135 \mathrm{kBtu} / \mathrm{h}(39.6 \mathrm{~kW})$ across all climate locations.

Based on Table 6.8.1D in Standard 90.1-2004, the minimum efficiency for a PTAC (new construction) with $9 \mathrm{kBtu} / \mathrm{h}(2.6 \mathrm{~kW})$ cooling capacity is 10.6 EER. The air flow at the rating condition is assumed to be $275 \mathrm{cfm}\left(0.13 \mathrm{~m}^{3} / \mathrm{s}\right)$ based on Chapter 7 of Packaged Terminal Air Conditioners and Heat Pumps Energy Conservation Standard Notice of Proposed Rulemaking Technical Support Document (DOE 2008). The fan power is assumed to be $82.5 \mathrm{~W}$ based on $0.3 \mathrm{~W} / \mathrm{cfm}\left(634.6 \mathrm{~W} / \mathrm{m}^{3} / \mathrm{s}\right)$ from Appendix G of Standard 90.1-2007 (ANSI/ASHRAE/IESNA 2007). Using these assumptions and Equation (4.2), the COP for the PTAC is 3.54 .

Gas furnaces less than $225,000 \mathrm{Btu} / \mathrm{h}(65,940 \mathrm{~W})$ are rated by thermal efficiency $\left(\mathrm{E}_{\mathrm{t}}\right)$ or average fuel utilization efficiency (AFUE) which, like SEER, represents average annual efficiency. The efficiency requirement for these units is $78 \%$ AFUE or $80 \% \mathrm{E}_{\mathrm{t}}$. Furnaces larger than $225,000 \mathrm{Btu} / \mathrm{h}(65,940 \mathrm{~W})$ must meet an $80 \%$ combustion efficiency $\left(\mathrm{E}_{\mathrm{c}}\right)$. Table 4.9 summarizes the baseline equipment efficiency for the HVAC systems in the prototype. 
Table 4.9. Baseline HVAC Equipment Efficiency

\begin{tabular}{|c|c|c|c|c|}
\hline \multirow[b]{3}{*}{$\begin{array}{l}\text { HVAC } \\
\text { Type }\end{array}$} & \multirow[b]{3}{*}{ Size Category } & \multicolumn{3}{|c|}{$\begin{array}{c}\text { Minimum Efficiency from ASHRAE } \\
\text { Standard 90.1- } 2004\end{array}$} \\
\hline & & \multicolumn{2}{|c|}{ Cooling } & \multirow[b]{2}{*}{ Heating } \\
\hline & & $\begin{array}{c}\text { Efficiency } \\
\text { (SEER/EER) }\end{array}$ & $\begin{array}{l}\text { EnergyPlus } \\
\text { Input (COP) }\end{array}$ & \\
\hline PTAC & $\begin{array}{l}9 \mathrm{kBtu} / \mathrm{h} \\
(2.6 \mathrm{~kW})\end{array}$ & 10.6 EER & 3.54 & $100 \% \mathrm{E}_{\mathrm{t}}$ \\
\hline \multirow{2}{*}{$\begin{array}{l}\text { Split air } \\
\text { conditioner }\end{array}$} & $\begin{array}{l}<65 \mathrm{kBtu} / \mathrm{h} \\
(<19.0 \mathrm{~kW})\end{array}$ & 10.0 SEER & 3.22 & \multirow[b]{2}{*}{$80 \% \mathrm{E}_{\mathrm{t}}$} \\
\hline & $\begin{array}{l}\geq 65 \mathrm{kBtu} / \mathrm{h} \text { and }<135 \mathrm{kBtu} / \mathrm{h} \\
(\geq 19.0 \mathrm{~kW} \text { and }<39.6 \mathrm{~kW})\end{array}$ & 10.1 EER & 3.50 & \\
\hline \multirow{2}{*}{$\begin{array}{l}\text { Make-up } \\
\text { air unit }\end{array}$} & $\begin{array}{l}<65 \mathrm{kBtu} / \mathrm{h} \\
(<19.0 \mathrm{~kW})\end{array}$ & 9.7 SEER & 3.15 & \multirow{2}{*}{$80 \% \mathrm{E}_{\mathrm{t}}$} \\
\hline & $\begin{array}{l}\geq 65 \mathrm{kBtu} / \mathrm{h} \text { and }<135 \mathrm{kBtu} / \mathrm{h} \\
(\geq 19.0 \mathrm{~kW} \text { and }<39.6 \mathrm{~kW})\end{array}$ & 10.1 EER & 3.50 & \\
\hline Unit heater & All capacities & & & $100 \% \mathrm{E}_{\mathrm{t}}$ \\
\hline
\end{tabular}

\subsubsection{HVAC System Fan Power}

ASHRAE Standard 90.1-2004 specifies maximum fan power allowances for fans with motors exceeding $5 \mathrm{hp}(3.73 \mathrm{~kW})$. Because the fan motors in the baseline highway lodging building do not exceed $5 \mathrm{hp}(3.73 \mathrm{~kW})$, there is no minimum requirement; therefore fan power has been determined based on typical equipment and air distribution systems.

The EnergyPlus program calculates the fan power by taking three inputs for a constant air volume fan: 1) the design pressure drop through the fan, 2) total fan efficiency, 3) and the motor efficiency. Typical fan power for the PTACs is assumed to be $0.30 \mathrm{~W} / \mathrm{cfm}\left(638 \mathrm{~W} / \mathrm{m}^{3} / \mathrm{s}\right)$ (based on ASHRAE Standard 90.1-2007, Appendix G). The pressure drop across the PTAC supply fan was back calculated as 1.33 inch water column (in. w.c.) (331 Pa), assuming an 80\% efficient motor and a $65 \%$ efficient fan (total efficiency 52\%).

It is assumed that the split air conditioners contain only a supply fan, and there is no return fan or central exhaust fan in the system. Based on the study by Wassmer and Brandemuehl (2006), the supply fan power of a split system is correlated with the system SEER, as shown in Equation (4.3).

$$
\text { watts } / c f m=-0.0304 \times S E E R+0.686
$$

The design pressure drop through the fan can be calculated using the following equation:

$$
T S P=B H P \times E f f \text { fan } \times 6356 / C F M
$$

where $\quad$ TSP $=$ design total static pressure, in. w.c. 
$\mathrm{CFM}=$ supply fan air flow as determined by EnergyPlus sizing runs, $\mathrm{cfm}$

Eff $_{\text {fan }}=65 \%$, based on assumptions used by the ASHRAE Standard 90.1 Committee while developing fan power requirements for the Standard.

BHP $=$ brake horsepower is assumed to equal $90 \%$ of the maximum nameplate horsepower allowed for the supply cfm by Standard 90.1 .

To calculate the total supply fan static pressure drop in the MAU system serving all the guest rooms in the baseline building, two elements have to be considered. These are the air handler's internal static pressure drop and the air distribution system external static pressure drop. The internal static pressure is the static pressure drop across the packaged unitary equipment while operating, and was estimated based on the manufacturer's product performance data for this category of equipment with a gas furnace. The external static pressure calculation is based on the standard HVAC ductwork design method for representative duct runs served by this class of equipment. Table 4.10 summarizes the breakdown calculation of the fan total static pressure for the 10-ton $(35.2 \mathrm{~kW})$ MAU system, which resulted in a total fan static pressure of 1.55 in. w.c (386 Pa). The total pressure drop for the guest room toilet exhaust system was assumed to be 0.5 in. w.c $(125 \mathrm{~Pa})$.

Table 4.10. Total Fan Static Pressure Drops Calculations for Baseline MAU System

\begin{tabular}{|c|c|}
\hline Component & Pressure Drop \\
\hline \multicolumn{2}{|c|}{ Internal Static Pressure, in. w.c. $(\mathrm{Pa})^{(\mathrm{a})}$} \\
\hline 8-Row DX coil & $0.58(145)$ \\
\hline Gas heating section & $0.14(35)$ \\
\hline 2 in. plated filters ${ }^{(b)}$ & $0.17(41)$ \\
\hline Acoustical curb & $0.07(17)$ \\
\hline Subtotal & $0.97(238)$ \\
\hline \multicolumn{2}{|c|}{ External Static Pressure, in. w.c. $(\mathrm{Pa})^{(\mathrm{c})}$} \\
\hline Diffuser & $0.10(25)$ \\
\hline Supply ductwork ${ }^{(\mathrm{d})}$ & $0.24(60)$ \\
\hline Fan outlet transition & $0.20(50)$ \\
\hline Subtotal & $0.54(135)$ \\
\hline $10 \%$ Safety factor & $0.05(13)$ \\
\hline Subtotal & $0.59(147)$ \\
\hline & $1.55(386)$ \\
\hline \multicolumn{2}{|l|}{ Total static pressure drops } \\
\hline \multicolumn{2}{|c|}{$\begin{array}{l}\text { (a) Internal static pressure drops were derived from McQuay product catalog for } \\
\text { Skyline Outdoor Air Handler } 2007 \text {. } \\
\text { (b) Used average difference between the clean and dirty filters. } \\
\text { (c) External static pressure was calculated based on the typical duct runs served by the } \\
\text { listed cooling capacities. } \\
\text { (d) Used standard practice of } 0.1 \mathrm{in} . / 100 \mathrm{ft}(8.2 \mathrm{~mm} / 100 \mathrm{~m}) \text { friction rate for the } \\
\text { baseline prototypes. }\end{array}$} \\
\hline
\end{tabular}

A fan mechanical efficiency of $65 \%$ is used in the modeling based on assumptions used by the ASHRAE Standard 90.1 Committee while developing fan power requirements for the Standard. The last required input, motor efficiency, is taken directly from Table 10.8 of Standard 90.1- 2004, based on motor nameplate, assuming enclosed motors operating at 1,800 RPM. The efficiency chosen from Table 10.8 is for the first size motor larger than the calculated brake horsepower, unless the first larger size is within $110 \%$ of the brake horsepower, in which case the efficiency from the next larger motor is used. 


\subsubsection{Ventilation Rates and Schedules}

Outdoor air (OA) ventilation requirements used in the base case are as required by ASHRAE Standard 62.1-2004 (ANSI/ASHRAE 2004), which has ventilation requirements based on space type. Table 4.11 shows the minimal outdoor air requirement for each space type in the highway lodging prototype. It was assumed that outdoor air was supplied to the guest rooms through a MAU system.

Table 4.11. Minimum Outside Air Requirement by Space Type

\begin{tabular}{lcc}
\hline & \multicolumn{2}{c}{ Minimum Outside Air } \\
\cline { 2 - 3 } \multicolumn{1}{c}{ Space Type } & $\begin{array}{c}\text { People Outdoor Air Rate } \\
\mathrm{cfm} / \text { person } \\
\left(\mathrm{m}^{3} / \mathrm{s} / \text { person }\right)\end{array}$ & $\begin{array}{c}\text { Area Outdoor Air Rate } \\
\mathrm{cfm}^{2} \mathrm{ft}^{2} \\
\left(\mathrm{~m}^{3} / \mathrm{s} / \mathrm{m}^{2}\right)\end{array}$ \\
\hline Guest room & $5(0.0024)$ & $0.06(0.0003)$ \\
Corridor & - & $0.06(0.0003)$ \\
Lobby & $7.5(0.0035)$ & $0.06(0.0003)$ \\
Storage & - & $0.12(0.0006)$ \\
Office & $5(0.0024)$ & $0.06(0.0003)$ \\
Meeting room & $5(0.0024)$ & $0.06(0.0003)$ \\
Restroom ${ }^{(a)}$ & 0 & 0 \\
Exercise room & $20(0.0094)$ & $0.06(0.0003)$ \\
Employee lounge & $5(0.0024)$ & $0.06(0.0003)$ \\
\hline
\end{tabular}

(a) ASHRAE Standard 62-1999 specifies $50 \mathrm{cfm} /$ water closet (wc) or cfm/urinal of outdoor air ventilation air for public restrooms. But these OA ventilation air can by supplied by transfer air. Reviewing the Hampton Inn protocol blueprints and Staybridge protocol blueprints shows that no outdoor air is supplied to restrooms. Instead, exhaust air of $50 \mathrm{cfm} / \mathrm{wc}$ or $50 \mathrm{cfm} / \mathrm{urinal}$ is applied in practice. Thus, no outdoor is applied to public restrooms separately in this study.

Based on Section 6.4.3.4 of Standard 90.1-2004, motorized damper control is required that will automatically shut when the systems or spaces served are not in use except for (a) systems in buildings less than three stories in height and for buildings of any height located in climate Zones 1, 2, and 3; or (b) systems with a design outdoor air intake or exhaust capacity of $300 \mathrm{cfm}\left(0.144 \mathrm{~m}^{3} / \mathrm{s}\right)$ or less. Because the outdoor air rate requirements for the systems serving the meeting room, exercise room and employee lounge, which are usually not in use during night time, are less than $300 \mathrm{cfm}\left(0.144 \mathrm{~m}^{3} / \mathrm{s}\right)$, gravity dampers were assumed for these systems and other systems that are in continuous operation, and the ventilation air was supplied to the spaces continuously.

\subsubsection{Economizer Use}

The baseline HVAC systems were simulated with economizers when required by Standard 90.12004. The Standard does not require economizers if the system cooling capacity is less than $65,000 \mathrm{Btu} / \mathrm{h}$ $(19 \mathrm{~kW})$ regardless of climate zone. For cooling capacities greater than $65,000 \mathrm{Btu} / \mathrm{h}(19 \mathrm{~kW})$ economizers are required depending on the climate zone and the capacity as indicated in Table 4.12. All of the PTACs are below this threshold and air economizers are not required. For the systems servings the public spaces, some are large enough to require economizers, based on the zone served and climate. 
The baseline building simulation assumed that the economizer high limit shutoff was controlled by differential dry bulb temperature in climate zones where this control type is allowed by the Standard. For climate zones where differential dry bulb temperature is prohibited by the Standard, the economizer high limit shutoff was controlled by fixed dry bulb temperature. Under the control type of differential dry bulb, when the outdoor air temperature is below both the return air temperature and the high ambient shutoff temperature, the economizer is enabled.

Table 4.12. Economizer Requirements in Standard 90.1-2004

\begin{tabular}{|c|c|c|c|}
\hline Climate Zone & $\begin{array}{c}\text { Representative } \\
\text { City }\end{array}$ & $\begin{array}{c}\text { Economizer Required if } \\
\text { Cooling Capacity } \\
\geq 65,000 \mathrm{Btu} / \mathrm{h} \text { and } \\
<135,000 \mathrm{Btu} / \mathrm{h} \\
(\geq 19 \mathrm{~kW} \text { and }<40 \mathrm{~kW})\end{array}$ & $\begin{array}{c}\text { Economizer Required } \\
\text { if Cooling Capacity } \\
\geq 135,000 \mathrm{Btu} / \mathrm{h} \\
(\geq 40 \mathrm{~kW})\end{array}$ \\
\hline Zone $1 \mathrm{~A}$ & Miami & No & No \\
\hline Zone 2A & Houston & No & No \\
\hline Zone 2B & Phoenix & No & Yes \\
\hline Zone $3 \mathrm{~A}$ & Atlanta & No & No \\
\hline Zone 3B & Los Angeles & Yes & Yes \\
\hline Zone 3B & Las Vegas & Yes & Yes \\
\hline Zone 3C & San Francisco & Yes & Yes \\
\hline Zone 4A & Baltimore & No & No \\
\hline Zone 4B & Albuquerque & Yes & Yes \\
\hline Zone 4C & Seattle & Yes & Yes \\
\hline Zone $5 \mathrm{~A}$ & Chicago & No & Yes \\
\hline Zone 5B & Denver & Yes & Yes \\
\hline Zone $6 \mathrm{~A}$ & Minneapolis & No & Yes \\
\hline Zone $6 \mathrm{~B}$ & Helena & Yes & Yes \\
\hline Zone 7 & Duluth & No & Yes \\
\hline Zone 8 & Fairbanks & No & Yes \\
\hline
\end{tabular}

\subsection{Service Water Heating System}

The baseline service hot water system for the highway lodging buildings is defined as a gas-fired storage water heater with a hot water recirculation loop for guest room shower, and a separate hot water recirculation loop and a gas-fired storage water heater for laundry. Gas storage water heaters were chosen based on the inputs from the lodging industry experts as well as the 2003 CBECS data, which shows the most typical fuel used for water heating in hotels/motels with less than 80 rooms is natural gas (Figure 4.6). The equipment meets the minimum equipment efficiency requirements under Standard 90.1-2004. The hot water supply temperatures were assumed to be $140^{\circ} \mathrm{F}\left(60^{\circ} \mathrm{C}\right)$ for laundry and $120^{\circ} \mathrm{F}$ $\left(48.9^{\circ} \mathrm{C}\right)$ for guest rooms, respectively. 


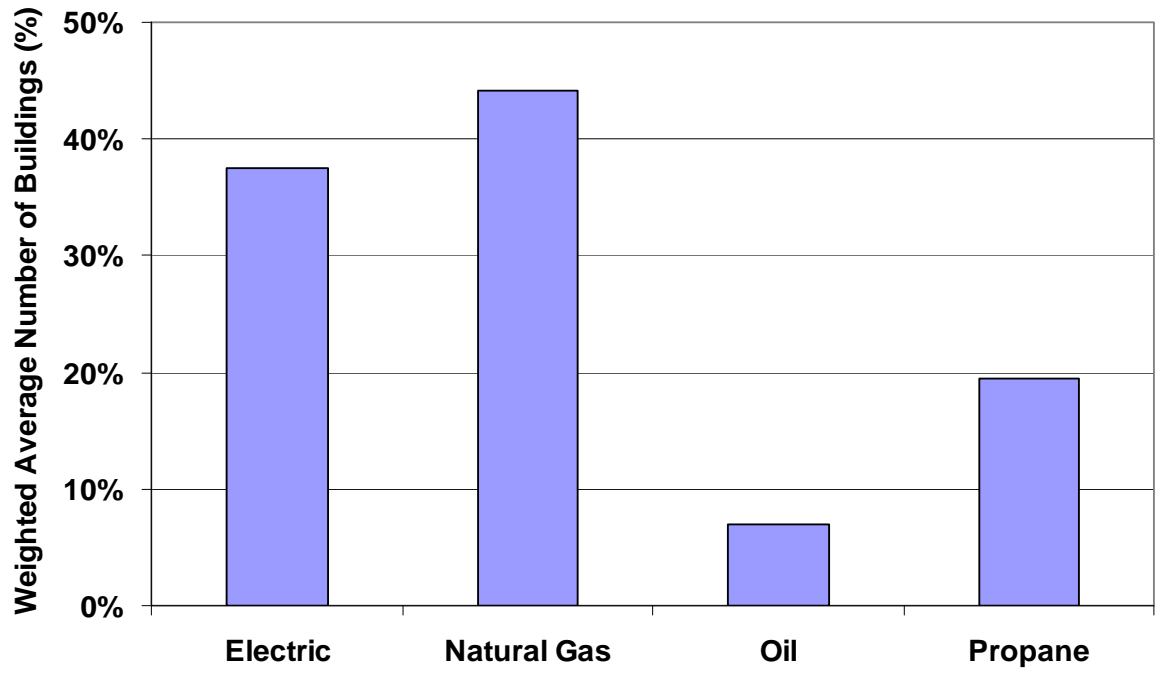

Figure 4.6. Water Heating Equipment Categories in 2003 CBECS (for motel/hotels with less than 80 rooms)

To estimate the energy performance of a service water heater with a storage tank, the EnergyPlus program requires the user to define the following key input variables as the operating parameters:

- the rated storage tank volume in gallons

- peak hot water flow rate

- hot water use schedule

- the maximum heater capacity - the heating capacity of the burner used to meet the domestic hot water load and charge the tank

- the standby heat loss coefficient $(U A)$ in $\mathrm{Btu} /{ }^{\circ} \mathrm{F} \cdot \mathrm{h}(\mathrm{W} / \mathrm{K})$

- the heater thermal efficiency $\left(E_{t}\right)$ - this is a ratio of heating capacity at full load to gas heat input.

The following sections document the assumptions for hot water usage, rated storage tank volume, rated input power, standby heat loss coefficient (UA), and heat input ratio in the baseline service water heating system.

\subsubsection{Hot Water Usage}

The hot water consumption in hotel buildings that do not contain substantial food service facilities are from two major users: guest room hot water use and laundry hot water use. The typical hot water use for a guest room is 14 gallon/day (53.0 L/day) based on Table 7 of Chapter 49 in 2007 ASHRAE Handbook: HVAC Applications (ASHRAE 2007). The hot water demand for laundry use was calculated to be 10.8 gallon/day-unit (40.9 L/day-unit), based on the lodging industry data as shown below.

- The average laundry for a guest room is $9 \mathrm{lb} / \mathrm{day}(4 \mathrm{~kg} /$ day $)$.

- The water needed for $1 \mathrm{lb}(0.45 \mathrm{~kg})$ of laundry is 3 gallons $(11.4 \mathrm{~L})$. 
- Hot water use is approximately $40 \%$ of the total water used for laundry.

The EnergyPlus program calculates hot water usage using two inputs: peak hot water flow rate and hot water use schedule. The schedules for both guest rooms and laundry are shown in Appendix A. The peak hot water flow rates were back calculated based on the total daily hot water consumption and the schedules, which were $0.046 \mathrm{gpm}(0.003 \mathrm{~L} / \mathrm{s})$ for the guest room and $1.73 \mathrm{gpm}(0.11 \mathrm{~L} / \mathrm{s})$ for the laundry use. Appendix A includes schedules of service hot water use in the guest rooms and laundry.

\subsubsection{Storage Tank Size}

The water heater storage tank volume was sized based on the methodology described in the 2007 ASHRAE Handbook: HVAC Applications (ASHRAE 2007). According to Table 7 of Chapter 49, the maximum hourly hot water demand is 5.0 gallon/unit $(18.9 \mathrm{~L} / \mathrm{unit})$ for motels with 60 units. The hourly hot water demand for laundry use is 1.35 gallon/day-unit $(5.1 \mathrm{~L} /$ day-unit) based on the assumptions in Section 4.4.1. Assuming a recovery rate of 3.5 gallon/unit $(13.3 \mathrm{~L} / \mathrm{unit})$, the usable storage capacity is 2.7 gallon/unit (10.2 L/unit) using the curve in Figure 17 in Chapter 49 of 2007 ASHRAE Handbook, resulting in a 300 gallons $(1,136 \mathrm{~L})$ storage capacity if $70 \%$ of the hot water is usable. Therefore, the service water heating system for the highway lodging prototype was sized as three 100-gallon (379 L) water heaters with two 100-gallon (379 L) water heaters for guest room shower and one 100-gallon (379 L) water heater for the laundry, respectively.

\subsubsection{Rated Input Power and Standby Heat Loss Coefficient}

For commercial gas storage water heaters, the minimum performance required is expressed as two values, thermal efficiency $E_{t}$ and the standby loss $S L$. Based on manufacturer's equipment specifications for commercial water heaters, the most common input rating of a 100-gallon $(379 \mathrm{~L})$ gas storage water heater is $199,000 \mathrm{Btu} / \mathrm{h}(58,320 \mathrm{~W})$, with recovery efficiency of $80 \%$. The maximum standby loss $S L$ is $1,349 \mathrm{Btu} / \mathrm{h}(395 \mathrm{~W})$ using following equation required in the Standard:

$$
S L=\frac{Q}{800}+110 \sqrt{V}
$$

where $S L=$ standby heat loss $(\mathrm{Btu} / \mathrm{h})$

$Q=$ rated input power $(\mathrm{Btu} / \mathrm{h})$

$V=$ rated storage tank volume (gallons)

Furthermore, the $U A$ of the commercial heater was determined using the following equation:

$$
U A=\frac{S L \times R E}{70}
$$

where $U A=$ standby heat loss efficient $\left(\mathrm{Btu} /{ }^{\circ} \mathrm{F} \cdot \mathrm{h}\right)$

$S L=$ standby heat loss $(\mathrm{Btu} / \mathrm{h})$

$R E=$ recovery efficiency

$70=$ difference in temperature between stored water thermostat set point and ambient air temperature at the test condition $\left({ }^{\circ} \mathrm{F}\right)$ 
Inserting the appropriate values for $S L$ and $R E$, results in a UA of $15.414 \mathrm{Btu} /{ }^{\circ} \mathrm{F} \cdot \mathrm{h}(8.13 \mathrm{~W} / \mathrm{K})$, as one of input variables for modeling the water heater in the EnergyPlus program.

\subsubsection{Water Heater Thermal Efficiency}

The water heater thermal efficiency $E_{t}$ was set as $80 \%$ to match the minimum performance requirement under the Standard for gas storage water heater with rated input $\geq 76,000 \mathrm{Btu} / \mathrm{h}(22.3 \mathrm{~kW})$. 


\subsection{Development of Advanced Building Model and Assumptions}

The advanced building model is developed by adding a number of energy efficiency measures (EEMs) to the baseline building model. The candidate EEMs are developed with the following major considerations:

- The starting points to determine candidate EEMs are those recommendations in the published ASHRAE's Advanced Energy Design Guide for Highway Lodging Buildings (Jiang et al. 2008), the approved and proposed addenda to ASHRAE Standard 90.1-2007.

- The EEMs are based on technologies that are commercially available from multiple sources. Technologies or techniques that are one-of-a-kind or available from a single manufacturer are not recommended.

- The EEMs can be modeled by the current version of the EnergyPlus simulation program.

- The EEMs address four building systems: building envelope, HVAC, service water heating, lighting, and plug loads.

To quantify the potential energy savings from the recommended EEMs in the design package, the advanced building models were simulated by implementing the energy-efficiency technologies noted below. This section contains a topic-by-topic review of advanced building models and how the recommended EEMs were implemented into the advanced building models. The EEMs include the following:

- enhanced building opaque envelope insulation

- cool roof

- $\quad$ high-performance windows

- reduced lighting power density and advanced lighting controls for both interior lighting and exterior lighting

- occupancy-based central management system

- high-efficiency appliances and laundry equipment

- water-source heat pump (WSHP) application

- energy recovery ventilator (ERV)

- motorized damper control

- reduced air-side pressure drop design

- condensing water heater and boiler

- hot water use reduction

- drain waste water heat recovery. 


\subsection{Envelope}

The advanced building models incorporate various energy efficiency measures while maintaining the same building form, orientation, window-to-wall ratios on each façade, and wall and roof construction types as those used in the baseline buildings. The envelope EEMs were derived based on the morestringent envelope recommendations from the AEDG-HL and the public review draft of Addendum bb to ASHRAE Standard 90.1-2007.

\subsubsection{Enhanced Insulation for Opaque Assemblies}

Opaque assemblies, such as roof, walls, floors and doors, were modeled as having the same construction types and heat capacity as the baseline buildings, but with the enhanced insulation recommended in the design package. The enhanced insulation requirements are achieved by changing the insulation layers' thermal resistance. Because only thermal resistance is modeled for the insulation layers in this study, the thermal mass of the opaque assemblies does not change between the baseline and the advanced models.

Table 5.1 shows the roof assembly U-factors and the corresponding insulation R-values for both baseline and advanced models. Similarly, Table 5.2 shows the wall assembly U-factors and R-values, and Table 5.3 shows slab-on-grade floor F-factor and the corresponding insulation R-values and distance requirements.

Table 5.1. Insulation Requirements Comparison for Roofs with Insulation Entirely Above Deck

\begin{tabular}{|c|c|c|c|c|}
\hline \multirow[b]{2}{*}{$\begin{array}{l}\text { Climate } \\
\text { Zone }\end{array}$} & \multicolumn{2}{|c|}{ Baseline } & \multicolumn{2}{|c|}{ Advanced Model } \\
\hline & $\begin{array}{c}\text { Assembly U-Factor } \\
\mathrm{Btu} /{ }^{\circ} \mathrm{F} \cdot \mathrm{h} \cdot \mathrm{ft}^{2} \\
\left(\mathrm{~W} / \mathrm{K} \cdot \mathrm{m}^{2}\right)\end{array}$ & $\begin{array}{c}\text { Rated Insulation } \\
\text { R-Value } \\
{ }^{\circ} \mathrm{F} \cdot \mathrm{h} \cdot \mathrm{ft}^{2} / \mathrm{Btu}\left(\mathrm{K} \cdot \mathrm{m}^{2} / \mathrm{W}\right)\end{array}$ & $\begin{array}{c}\text { Assembly U-Factor } \\
\mathrm{Btu} /{ }^{\circ} \mathrm{F} \cdot \mathrm{h} \cdot \mathrm{ft}^{2} \\
\left(\mathrm{~W} / \mathrm{K} \cdot \mathrm{m}^{2}\right)\end{array}$ & $\begin{array}{c}\text { Rated Insulation } \\
\text { R-Value } \\
{ }^{\circ} \mathrm{F} \cdot \mathrm{h} \cdot \mathrm{ft}^{2} / \mathrm{Btu}\left(\mathrm{K} \cdot \mathrm{m}^{2} / \mathrm{W}\right)\end{array}$ \\
\hline 1 & $0.063(0.358)$ & $\begin{array}{c}\text { R-15 c.i. } \\
\text { (R-2.6 c.i.) }\end{array}$ & $0.039(0.220)$ & $\begin{array}{c}\text { R-25 c.i. } \\
\text { (R-4.4 c.i.) }\end{array}$ \\
\hline 2 & $0.063(0.358)$ & $\begin{array}{l}\text { R-15 c.i. } \\
\text { (R-2.6 c.i.) }\end{array}$ & $0.039(0.220)$ & $\begin{array}{l}\text { R-25 c.i. } \\
\text { (R-4.4 c.i.) }\end{array}$ \\
\hline 3 & $0.063(0.358)$ & $\begin{array}{l}\text { R-15 c.i. } \\
\text { (R-2.6 c.i.) }\end{array}$ & $0.039(0.220)$ & $\begin{array}{l}\text { R-25 c.i. } \\
\text { (R-4.4 c.i.) }\end{array}$ \\
\hline 4 & $0.063(0.358)$ & $\begin{array}{l}\text { R-15 c.i. } \\
\text { (R-2.6 c.i.) }\end{array}$ & $0.032(0.184)$ & $\begin{array}{l}\text { R-30 c.i. } \\
\text { (R-5.3 c.i.) }\end{array}$ \\
\hline 5 & $0.063(0.358)$ & $\begin{array}{l}\text { R-15 c.i. } \\
\text { (R-2.6 c.i.) }\end{array}$ & $0.032(0.184)$ & $\begin{array}{l}\text { R-30 c.i. } \\
\text { (R-5.3 c.i.) }\end{array}$ \\
\hline 6 & $0.063(0.358)$ & $\begin{array}{l}\text { R-15 c.i. } \\
\text { (R-2.6 c.i.) }\end{array}$ & $0.032(0.184)$ & $\begin{array}{l}\text { R-30 c.i. } \\
\text { (R-5.3 c.i.) }\end{array}$ \\
\hline 7 & $0.063(0.358)$ & $\begin{array}{l}\text { R-15 c.i. } \\
\text { (R-2.6 c.i.) }\end{array}$ & $0.028(0.159)$ & $\begin{array}{l}\text { R-35 c.i. } \\
\text { (R-6.2 c.i.) }\end{array}$ \\
\hline 8 & $0.048(0.273)$ & $\begin{array}{c}\text { R-20 c.i. } \\
\text { (R-3.5 c.i.) }\end{array}$ & $0.028(0.159)$ & $\begin{array}{l}\text { R-35 c.i. } \\
\text { (R-6.2 c.i.) }\end{array}$ \\
\hline
\end{tabular}


Table 5.2. Insulation Requirements Comparison for Above-Grade Mass Walls

\begin{tabular}{|c|c|c|c|c|c|c|}
\hline \multirow[b]{2}{*}{$\begin{array}{c}\text { Climate } \\
\text { Zone }\end{array}$} & \multicolumn{2}{|c|}{ Baseline - Residential } & \multicolumn{2}{|c|}{ Baseline - Non-Residential } & \multicolumn{2}{|c|}{ Advanced Model } \\
\hline & $\begin{array}{c}\text { Assembly } \\
\mathrm{U}-\mathrm{Factor} \\
\mathrm{Btu} /{ }^{\circ} \mathrm{F} \cdot \mathrm{h} \cdot \mathrm{ft}^{2} \\
\left(\mathrm{~W} / \mathrm{K} \cdot \mathrm{m}^{2}\right)\end{array}$ & $\begin{array}{c}\text { Rated Insulation } \\
\text { R-Value } \\
{ }^{\circ} \mathrm{F} \cdot \mathrm{h} \cdot \mathrm{ft}^{2} / \mathrm{Btu} \\
\left(\mathrm{K} \cdot \mathrm{m}^{2} / \mathrm{W}\right) \\
\end{array}$ & $\begin{array}{l}\text { Assembly } \\
\text { U-Factor } \\
\mathrm{Btu} /{ }^{\circ} \mathrm{F} \cdot \mathrm{h} \cdot \mathrm{ft}^{2} \\
\left(\mathrm{~W} / \mathrm{K} \cdot \mathrm{m}^{2}\right)\end{array}$ & $\begin{array}{c}\text { Rated Insulation } \\
\text { R-Value } \\
{ }^{\circ} \mathrm{F} \cdot \mathrm{h} \cdot \mathrm{ft}^{2} / \mathrm{Btu} \\
\left(\mathrm{K} \cdot \mathrm{m}^{2} / \mathrm{W}\right) \\
\end{array}$ & $\begin{array}{c}\text { Assembly } \\
\mathrm{U}-\mathrm{Factor} \\
\mathrm{Btu} /{ }^{\circ} \mathrm{F} \cdot \mathrm{h} \cdot \mathrm{ft}^{2} \\
\left(\mathrm{~W} / \mathrm{K} \cdot \mathrm{m}^{2}\right)\end{array}$ & $\begin{array}{c}\text { Rated Insulation } \\
\text { R-Value } \\
{ }^{\circ} \mathrm{F} \cdot \mathrm{h} \cdot \mathrm{ft}^{2} / \mathrm{Btu} \\
\left(\mathrm{K} \cdot \mathrm{m}^{2} / \mathrm{W}\right)\end{array}$ \\
\hline 1 & $\begin{array}{c}0.151 \\
(0.857)\end{array}$ & $\begin{array}{l}\text { R-5.7 c.i. } \\
\text { (R-1.0 c.i.) }\end{array}$ & $\begin{array}{c}0.58 \\
(3.293)\end{array}$ & NR & $\begin{array}{c}0.151 \\
(0.857)\end{array}$ & $\begin{array}{l}\text { R-5.7 c.i. } \\
\text { (R-1.0 c.i.) }\end{array}$ \\
\hline 2 & $\begin{array}{c}0.151 \\
(0.857)\end{array}$ & $\begin{array}{l}\text { R-5.7 c.i. } \\
\text { (R-1.0 c.i.) }\end{array}$ & $\begin{array}{c}0.58 \\
(3.293)\end{array}$ & NR & $\begin{array}{c}0.123 \\
(0.698)\end{array}$ & $\begin{array}{l}\text { R-7.6 c.i. } \\
\text { (R-1.3 c.i.) }\end{array}$ \\
\hline 3 & $\begin{array}{c}0.123 \\
(0.698)\end{array}$ & $\begin{array}{l}\text { R-7.6 c.i. } \\
\text { (R-1.3 c.i.) }\end{array}$ & $\begin{array}{c}0.151 \\
(0.857)\end{array}$ & $\begin{array}{l}\text { R-5.7 c.i. } \\
\text { (R-1.0 c.i.) }\end{array}$ & $\begin{array}{c}0.09 \\
(0.511)\end{array}$ & $\begin{array}{l}\text { R-11.4 c.i. } \\
\text { (R-2.0 c.i.) }\end{array}$ \\
\hline 4 & $\begin{array}{c}0.104 \\
(0.591)\end{array}$ & $\begin{array}{l}\text { R-9.5 c.i. } \\
\text { (R-1.7 c.i.) }\end{array}$ & $\begin{array}{c}0.151 \\
(0.857)\end{array}$ & $\begin{array}{l}\text { R-5.7 c.i. } \\
\text { (R-1.0 c.i.) }\end{array}$ & $\begin{array}{c}0.08 \\
(0.454)\end{array}$ & $\begin{array}{l}\text { R-13.3 c.i. } \\
\text { (R-2.3 c.i.) }\end{array}$ \\
\hline 5 & $\begin{array}{c}0.09 \\
(0.511)\end{array}$ & $\begin{array}{l}\text { R-11.4 c.i. } \\
\text { (R-2.0 c.i.) }\end{array}$ & $\begin{array}{c}0.123 \\
(0.698)\end{array}$ & $\begin{array}{l}\text { R-7.6 c.i. } \\
\text { (R-1.3 c.i.) }\end{array}$ & $\begin{array}{c}0.047 \\
(0.267)\end{array}$ & $\begin{array}{l}\text { R-19.5 c.i. } \\
\text { (R-3.4 c.i.) }\end{array}$ \\
\hline 6 & $\begin{array}{c}0.09 \\
(0.511)\end{array}$ & $\begin{array}{l}\text { R-11.4 c.i. } \\
\text { (R-2.0 c.i.) }\end{array}$ & $\begin{array}{c}0.104 \\
(0.591)\end{array}$ & $\begin{array}{l}\text { R-9.5 c.i. } \\
\text { (R-1.7 c.i.) }\end{array}$ & $\begin{array}{c}0.047 \\
(0.267)\end{array}$ & $\begin{array}{l}\text { R-19.5 c.i. } \\
\text { (R-3.4 c.i.) }\end{array}$ \\
\hline 7 & $\begin{array}{c}0.08 \\
(0.454)\end{array}$ & $\begin{array}{l}\text { R-13.3 c.i. } \\
\text { (R-2.3 c.i.) }\end{array}$ & $\begin{array}{c}0.09 \\
(0.511)\end{array}$ & $\begin{array}{l}\text { R-11.4 c.i. } \\
\text { (R-2.0 c.i.) }\end{array}$ & $\begin{array}{c}0.047 \\
(0.267)\end{array}$ & $\begin{array}{l}\text { R-19.5 c.i. } \\
\text { (R-3.4 c.i.) }\end{array}$ \\
\hline 8 & $\begin{array}{c}0.071 \\
(0.403)\end{array}$ & $\begin{array}{l}\text { R-15.2 c.i. } \\
\text { (R-2.7 c.i.) }\end{array}$ & $\begin{array}{c}0.08 \\
(0.454)\end{array}$ & $\begin{array}{l}\text { R-13.3 c.i. } \\
\text { (R-2.3 c.i.) }\end{array}$ & $\begin{array}{c}0.047 \\
(0.267)\end{array}$ & $\begin{array}{l}\text { R-19.5 c.i. } \\
\text { (R-3.4 c.i.) }\end{array}$ \\
\hline
\end{tabular}

Table 5.3. Insulation Requirements Comparison for Slab-on-Grade Floor

\begin{tabular}{|c|c|c|c|c|}
\hline \multirow[b]{2}{*}{$\begin{array}{l}\text { Climate } \\
\text { Zone }\end{array}$} & \multicolumn{2}{|c|}{ Baseline } & \multicolumn{2}{|c|}{ Advanced Model } \\
\hline & $\begin{array}{l}\text { Assembly F-Factor } \\
\mathrm{Btu} /{ }^{\circ} \mathrm{F} \cdot \mathrm{h} \cdot \mathrm{ft}(\mathrm{W} / \mathrm{K} \cdot \mathrm{m})\end{array}$ & $\begin{array}{l}\text { Rated insulation R-Value } \\
{ }^{\circ} \mathrm{F} \cdot \mathrm{h} \cdot \mathrm{ft}^{2} / \mathrm{Btu}\left(\mathrm{K} \cdot \mathrm{m}^{2} / \mathrm{W}\right)\end{array}$ & $\begin{array}{l}\text { Assembly U-Factor } \\
\mathrm{Btu} /{ }^{\circ} \mathrm{F} \cdot \mathrm{h} \cdot \mathrm{ft}(\mathrm{W} / \mathrm{K} \cdot \mathrm{m})\end{array}$ & $\begin{array}{l}\text { Rated Insulation R-Value } \\
{ }^{\circ} \mathrm{F} \cdot \mathrm{h} \cdot \mathrm{ft}^{2} / \mathrm{Btu}\left(\mathrm{K} \cdot \mathrm{m}^{2} / \mathrm{W}\right)\end{array}$ \\
\hline 1 & $\begin{array}{c}0.73 \\
(1.264)\end{array}$ & NR & $\begin{array}{c}0.73 \\
(1.264)\end{array}$ & NR \\
\hline 2 & $\begin{array}{c}0.73 \\
(1.264)\end{array}$ & NR & $\begin{array}{c}0.73 \\
(1.264)\end{array}$ & NR \\
\hline 3 & $\begin{array}{c}0.73 \mid \\
(1.264)\end{array}$ & NR & $\begin{array}{c}0.54 \\
(0.935)\end{array}$ & $\begin{array}{l}\mathrm{R}-10 \text { for } 24 \mathrm{in} . \\
\text { (R-1.8 for } 0.61 \mathrm{~m})\end{array}$ \\
\hline 4 & $\begin{array}{c}0.73 \\
(1.264)\end{array}$ & NR & $\begin{array}{l}0.52 \\
(0.9)\end{array}$ & $\begin{array}{l}\text { R-15 for } 24 \text { in. } \\
\text { (R-2.6 for } 0.61 \mathrm{~m} \text { ) }\end{array}$ \\
\hline 5 & $\begin{array}{c}0.73 \\
(1.264)\end{array}$ & NR & $\begin{array}{c}0.51 \\
(0.883)\end{array}$ & $\begin{array}{l}\text { R-20 for } 24 \mathrm{in} . \\
\text { (R-3.5 for } 0.61 \mathrm{~m})\end{array}$ \\
\hline 6 & $\begin{array}{c}0.73 \\
(1.264)\end{array}$ & NR & $\begin{array}{c}0.434 \\
(0.751)\end{array}$ & $\begin{array}{l}\text { R-20 for } 48 \text { in. } \\
\text { (R-3.5 for } 1.22 \mathrm{~m} \text { ) }\end{array}$ \\
\hline 7 & $\begin{array}{c}0.54 \\
(0.935)\end{array}$ & $\begin{array}{l}\mathrm{R}-10 \text { for } 24 \mathrm{in.} \\
(\mathrm{R}-1.8 \text { for } 0.61 \mathrm{~m})\end{array}$ & $\begin{array}{c}0.434 \\
(0.751)\end{array}$ & $\begin{array}{l}\mathrm{R}-20 \text { for } 48 \mathrm{in} . \\
\text { (R-3.5 for } 1.22 \mathrm{~m})\end{array}$ \\
\hline 8 & $\begin{array}{l}0.52 \\
(0.9)\end{array}$ & $\begin{array}{l}\mathrm{R}-15 \text { for } 24 \mathrm{in} . \\
\text { (R-2.6 for } 0.61 \mathrm{~m} \text { ) }\end{array}$ & $\begin{array}{c}0.424 \\
(0.734)\end{array}$ & $\begin{array}{l}\text { R-25 for } 48 \text { in. } \\
\text { (R-4.4 for } 1.22 \mathrm{~m} \text { ) }\end{array}$ \\
\hline
\end{tabular}




\subsubsection{Cool Roof}

A cool roof that reflects solar energy can be an effective energy-efficiency measure in hot climates (Jarnagin et al. 2006; Konopacki et al. 2001). Therefore, in the advanced models, the exterior layer of the built-up roof system is modeled as a light colored, reflective roofing membrane (such as white EPDM), which has solar reflectance of 0.65 (equivalent to solar reflectance index [SRI] of 78) and thermal emissivity of 0.87 , derived from a study by PG\&E (Eilert 2000). In contrast, the exterior roof layer in the baseline models is a kind of gray EPDM with solar reflectance of 0.23 and emissivity of 0.87 . Following the AEDGs (Jarnagin et al. 2006; Liu et al. 2006; Liu et al. 2007; Jiang et al. 2008), cool roof is used only in climate Zones 1 through 3.

\subsubsection{High Performance Windows}

The advanced models maintain the same window area as the baseline model, but change the window construction to have improved performance in terms of the U-value and the SHGC. The targeted U and SHGC values, as shown in Table 5.4, were derived based on the more-stringent recommendations from the AEDG-HL and the public review draft of Addendum bb to ASHRAE Standard 90.1-2007.

As described in Section 4.1.4, in the current version of EnergyPlus, a window's performance including the $\mathrm{U}$ and SHGC values is derived from the glazing layers' solar-optical properties. It is a challenge to manually find a hypothetical window construction that matches given U and SHGC values exactly. To address the above challenge, a simplified strategy was used to find the closest match of a window construction in the EnergyPlus window library for given U and SHGC values. In the matching process, a close match to the SHGC value is regarded as a more important criterion for climate Zones 1-3, where cooling load is a major consideration. On the other hand, a close match to the U-value is a more important criterion for climate Zones 4 through 8, where heating load is the major consideration. Because only a close match can be found, there is a minor deviation between the modeled U and SHGC values and the target values. Table 5.4 lists the actual performance for the selected window construction in both baseline and advanced cases. The effects of window frame and dividers are not modeled explicitly.

\subsection{Lighting}

Various lighting technologies were used to reduce the lighting energy use in highway lodging buildings. The lighting measures are not climate dependent. As such, the same EEMs are recommended for all climate zones. The implemented EEMs that address interior lighting include reduced interior lighting power density and occupancy sensor control. The EEMs that address exterior lighting include reduced exterior lighting power allowances and exterior lighting control. No daylighting harvesting, from vertical glazing or skylights, was evaluated in the study for highway lodging buildings.

\subsubsection{Interior Lighting}

Lighting energy use can be reduced via the use of energy-efficient lighting systems. When highperformance lighting technologies, such as compact fluorescent (CFL) with electronic ballast, T5HO or high-performance T8 with high-performance electronic ballast, combined with occupancy sensors, significant energy savings may be achieved from lighting. Use CFL in down lights, wall sconces, and table lamps. Use incandescent sparingly, such as in accent lighting of artwork or highlighting of special 
Table 5.4. Fenestration U-factor and SHGU Values Comparison

\begin{tabular}{|c|c|c|c|c|c|c|c|c|c|c|c|c|}
\hline \multirow[b]{4}{*}{$\begin{array}{c}\text { Climate } \\
\text { Zone }\end{array}$} & \multicolumn{4}{|c|}{ Baseline - Residential } & \multicolumn{4}{|c|}{ Baseline - Non-Residential } & \multicolumn{4}{|c|}{ Advanced Models } \\
\hline & \multicolumn{2}{|c|}{ Target Values } & \multicolumn{2}{|c|}{ Actual Values } & \multicolumn{2}{|c|}{ Target Values } & \multicolumn{2}{|c|}{ Actual Values } & \multicolumn{2}{|c|}{ Target Values } & \multicolumn{2}{|c|}{ Actual Values } \\
\hline & U-Factor & & U-Factor & & U-Factor & & U-Factor & & U-Factor & & U-Factor & \\
\hline & $\begin{array}{c}\mathrm{Btu} /{ }^{\circ} \mathrm{F} \cdot \mathrm{h} \cdot \mathrm{ft}^{2} \\
\left(\mathrm{~W} / \mathrm{K} \cdot \mathrm{m}^{2}\right)\end{array}$ & SHGC & $\begin{array}{c}\mathrm{Btu} /{ }^{\circ} \mathrm{F} \cdot \mathrm{h} \cdot \mathrm{ft}^{2} \\
\left(\mathrm{~W} / \mathrm{K} \cdot \mathrm{m}^{2}\right)\end{array}$ & SHGC & $\begin{array}{c}\mathrm{Btu} /{ }^{\circ} \mathrm{F} \cdot \mathrm{h} \cdot \mathrm{ft}^{2} \\
\left(\mathrm{~W} / \mathrm{K} \cdot \mathrm{m}^{2}\right)\end{array}$ & SHGC & $\begin{array}{c}\mathrm{Btu} /{ }^{\circ} \mathrm{F} \cdot \mathrm{h} \cdot \mathrm{ft}^{2} \\
\left(\mathrm{~W} / \mathrm{K} \cdot \mathrm{m}^{2}\right)\end{array}$ & SHGC & $\begin{array}{c}\mathrm{Btu} /{ }^{\circ} \mathrm{F} \cdot \mathrm{h} \cdot \mathrm{ft}^{2} \\
\left(\mathrm{~W} / \mathrm{K} \cdot \mathrm{m}^{2}\right)\end{array}$ & SHGC & $\begin{array}{c}\mathrm{Btu} /{ }^{\circ} \mathrm{F} \cdot \mathrm{h} \cdot \mathrm{ft}^{2} \\
\left(\mathrm{~W} / \mathrm{K} \cdot \mathrm{m}^{2}\right)\end{array}$ & SHGC \\
\hline 1 & $\begin{array}{c}1.23 \\
(6.98)\end{array}$ & 0.25 & $\begin{array}{c}1.08 \\
(6.13)\end{array}$ & 0.28 & $\begin{array}{c}1.23 \\
(6.98)\end{array}$ & 0.25 & $\begin{array}{c}1.08 \\
(6.13)\end{array}$ & 0.28 & $\begin{array}{c}0.56 \\
(3.18)\end{array}$ & 0.25 & $\begin{array}{c}0.51 \\
(2.90)\end{array}$ & 0.28 \\
\hline 2 & $\begin{array}{c}1.23 \\
(6.98)\end{array}$ & 0.25 & $\begin{array}{c}1.08 \\
(6.13)\end{array}$ & 0.28 & $\begin{array}{c}1.23 \\
(6.98)\end{array}$ & 0.25 & $\begin{array}{c}1.08 \\
(6.13)\end{array}$ & 0.28 & $\begin{array}{c}0.45 \\
(2.56)\end{array}$ & 0.25 & $\begin{array}{c}0.44 \\
(2.50)\end{array}$ & 0.24 \\
\hline $3 \mathrm{~A}, 3 \mathrm{~B}$ & $\begin{array}{c}0.59 \\
(3.35)\end{array}$ & 0.25 & $\begin{array}{c}0.51 \\
(2.90)\end{array}$ & 0.28 & $\begin{array}{c}0.59 \\
(3.35)\end{array}$ & 0.39 & $\begin{array}{c}0.55 \\
(3.12)\end{array}$ & 0.43 & $\begin{array}{c}0.41 \\
(2.33)\end{array}$ & 0.25 & $\begin{array}{c}0.40 \\
(2.27)\end{array}$ & 0.24 \\
\hline $3 \mathrm{C}$ & $\begin{array}{c}1.23 \\
(6.98)\end{array}$ & 0.39 & $\begin{array}{c}0.96 \\
(5.45)\end{array}$ & 0.37 & $\begin{array}{c}1.23 \\
(6.98)\end{array}$ & 0.61 & $\begin{array}{c}1.08 \\
(6.13)\end{array}$ & 0.61 & $\begin{array}{c}0.41 \\
(2.33)\end{array}$ & 0.25 & $\begin{array}{c}0.40 \\
(2.27)\end{array}$ & 0.24 \\
\hline 4 & $\begin{array}{c}0.59 \\
(3.35)\end{array}$ & 0.39 & $\begin{array}{c}0.55 \\
(3.12)\end{array}$ & 0.43 & $\begin{array}{c}0.59 \\
(3.35)\end{array}$ & 0.39 & $\begin{array}{c}0.55 \\
(3.12)\end{array}$ & 0.43 & $\begin{array}{c}0.38 \\
(2.16)\end{array}$ & 0.26 & $\begin{array}{c}0.40 \\
(2.27)\end{array}$ & 0.24 \\
\hline 5 & $\begin{array}{c}0.59 \\
(3.35)\end{array}$ & 0.39 & $\begin{array}{c}0.55 \\
(3.12)\end{array}$ & 0.43 & $\begin{array}{c}0.59 \\
(3.35)\end{array}$ & 0.39 & $\begin{array}{c}0.55 \\
(3.12)\end{array}$ & 0.43 & $\begin{array}{c}0.35 \\
(1.99)\end{array}$ & 0.26 & $\begin{array}{c}0.38 \\
(2.16)\end{array}$ & 0.23 \\
\hline 6 & $\begin{array}{c}0.59 \\
(3.350\end{array}$ & 0.39 & $\begin{array}{c}0.55 \\
(3.12)\end{array}$ & 0.43 & $\begin{array}{c}0.59 \\
(3.35)\end{array}$ & 0.39 & $\begin{array}{c}0.55 \\
(3.12)\end{array}$ & 0.43 & $\begin{array}{c}0.35 \\
(1.99)\end{array}$ & 0.35 & $\begin{array}{c}0.31 \\
(1.76)\end{array}$ & 0.38 \\
\hline 7 & $\begin{array}{c}0.59 \\
(3.35)\end{array}$ & 0.49 & $\begin{array}{c}0.55 \\
(3.12)\end{array}$ & 0.50 & $\begin{array}{c}0.59 \\
(3.35)\end{array}$ & 0.49 & $\begin{array}{c}0.55 \\
(3.12)\end{array}$ & 0.50 & $\begin{array}{c}0.33 \\
(1.87)\end{array}$ & 0.40 & $\begin{array}{c}0.31 \\
(1.76)\end{array}$ & 0.38 \\
\hline 8 & $\begin{array}{c}0.46 \\
(2.61)\end{array}$ & 0.45 & $\begin{array}{c}0.48 \\
(2.73)\end{array}$ & 0.47 & $\begin{array}{c}0.46 \\
(2.61)\end{array}$ & 0.45 & $\begin{array}{c}0.48 \\
(2.73)\end{array}$ & 0.47 & $\begin{array}{c}0.25 \\
(1.42)\end{array}$ & 0.40 & $\begin{array}{c}0.26 \\
(1.48)\end{array}$ & 0.37 \\
\hline
\end{tabular}


architectural features in the lobby. These technologies are readily available from major national suppliers, making it easy for designers and builders to find adequate supplies.

\subsubsection{Reduced Lighting Power Density}

The design package recommends the advanced interior lighting power density (LPD) levels based on lighting modeling studies performed by the lighting experts. In this work, the space-by-space method is followed to determine the interior lighting power allowance. The LPD for the whole building is derived from the percentage of each space type in terms of floor area and the designed LPD for each space. The recommendations for interior LPD, as summarized in Table 5.5 represent an average LPD for the individual spaces, not the entire building. Individual spaces within each space type may have higher power densities if they are offset by lower power densities in other areas within the same space type (breakfast room and elevator lobby would be considered part of the lobby and may be lighted to lower/higher light levels and, therefore, lower/higher LPD allowing higher/lower foot candles and LPD in the main lobby and registration area). The area-weighted average lighting level reductions in the advanced building models were $30 \%$ relative to the $90.1-2004$ baseline buildings.

Table 5.5. Interior Lighting Power Density by Space Type Comparison

\begin{tabular}{lcc}
\hline & \multicolumn{2}{c}{$\mathrm{L} / \mathrm{ft}^{2}\left(\mathrm{~W} / \mathrm{m}^{2}\right)$} \\
\cline { 2 - 3 } \multicolumn{1}{c}{ Space Type } & Baseline & Advanced Models \\
\hline Guest room & $1.1(11.84)$ & $0.71(7.64)$ \\
Corridor & $0.5(5.38)$ & $0.5(5.38)$ \\
Lobby & $1.1(11.84)$ & $0.77(8.29)$ \\
Stairs & $0.6(6.46)$ & $0.57(6.14)$ \\
Office & $1.1(11.84)$ & $0.85(9.15)$ \\
Laundry & $0.6(6.46)$ & $0.52(0.60)$ \\
Meeting room & $1.3(14.00)$ & $1.14(12.27)$ \\
Exercise room & $0.9(9.69)$ & $0.78(8.40)$ \\
Storage & $0.8(8.61)$ & $0.62(6.67)$ \\
Employee lounge & $1.2(12.92)$ & $0.82(8.83)$ \\
Restroom & $0.9(9.69)$ & $0.74(7.79)$ \\
Mechanical room & $1.5(16.15)$ & $1.24(13.35)$ \\
\hline Area-weighted average & $0.97(10.42)$ & $0.68(7.32)$ \\
\hline
\end{tabular}

\subsubsection{Occupancy Sensor Control}

Occupancy sensor controls are included for some of the hotel spaces, where occupancy control is not required by ASHRAE 90.1-2004. Occupancy-based guest room energy management systems can interface with guest room lighting controls, allowing the guest room lighting to be off when the sensor determines that the room is unoccupied. The lighting devices are controlled by the guest when in the room but turn off automatically when the guest leaves the room. Addendum aw to 90.1-2007 also requires that bathrooms in hotel guest rooms shall have a control device installed to automatically turn off the bathroom lighting, except for night lighting not exceeding $5 \mathrm{~W}$, within 60 minutes of the occupant leaving the space. These control measures are included in this design package. The impact of occupancy 
controls was modeled by reducing the baseline lighting levels by $80 \%$ for guest rooms during the unoccupied hours and sleep time, and 20\% for guest rooms during the occupied hours (CEC 2005).

Luminaries with an integrated occupancy sensor on all fixtures that provides a bi-level, low light level when the space is unoccupied and full light when occupied are recommended for stairs. Ceiling-mounted or wall-switch-mounted occupancy sensors for laundry, offices, exercise rooms, meeting rooms, employee lounge, mechanical/electrical rooms and storage rooms are also recommended in the design package, and, therefore, included in the simulation for the advanced building models. The impact of occupancy controls was modeled by modifying the baseline lighting levels by $15 \%$ for offices, $28 \%$ for exercise room, $40 \%$ for storage rooms and mechanical/electrical rooms, and $26 \%$ for restroom, to account for typical occupancy densities based on various studies (Jarnagin et al. 2006; Galasiu et al. 2007; VonNeida et al. 2000; LRC 2004). The lighting operation schedules for advanced buildings are documented in Appendix A. An example is show in Figure 5.1 for both baseline and advanced cases.

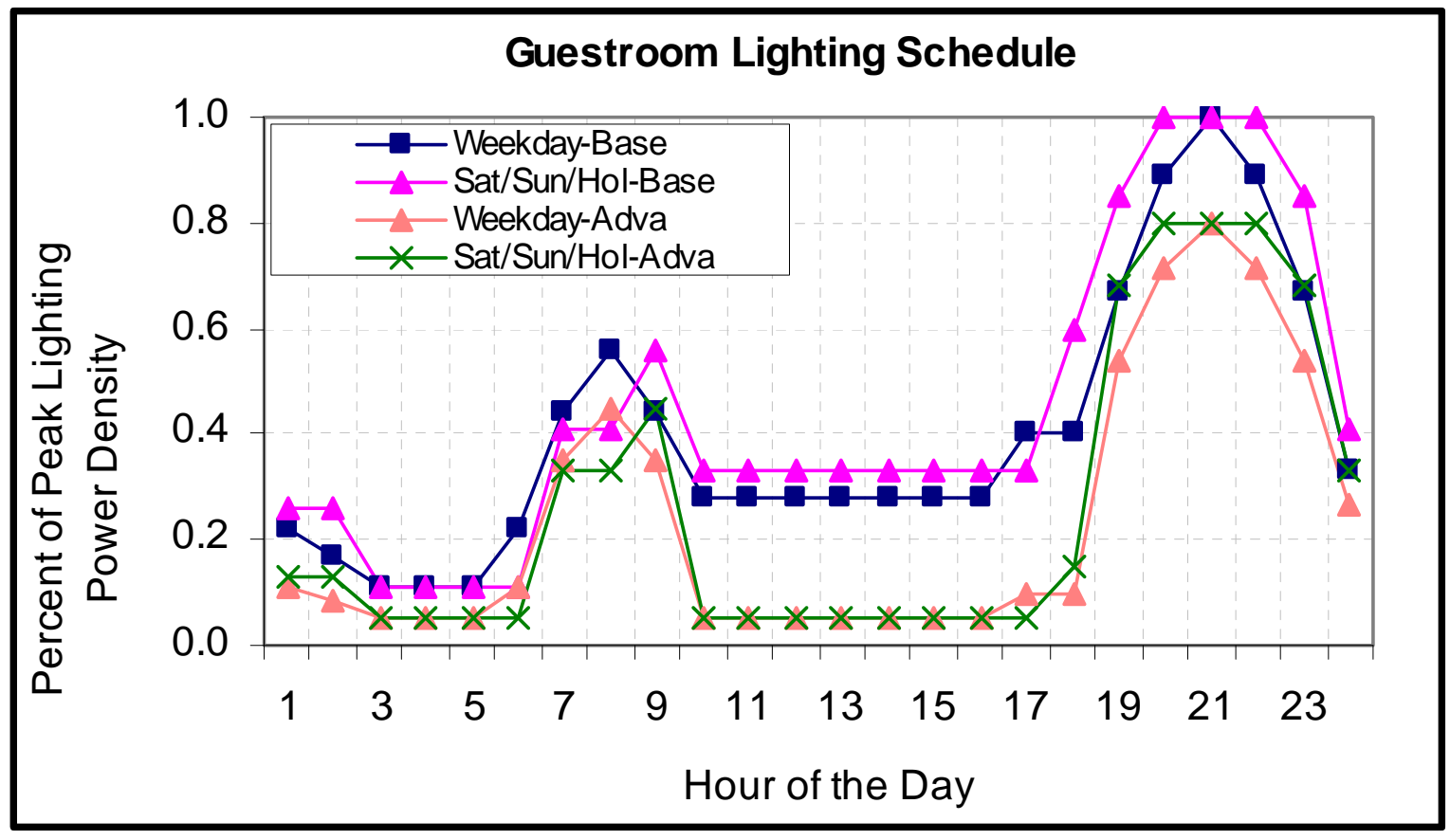

Figure 5.1. Guest Room Interior Lighting Schedule

\subsubsection{Exterior Lighting}

The EEMs for exterior lighting include measures for reducing exterior lighting power densities and advanced exterior lighting controls such as bi-level control for parking lots and time-of-day control for façade lighting.

\subsubsection{Reduced Exterior Lighting Power Allowances}

In the advanced models, the exterior lighting power density was calculated according to the lighting power allowances prescribed by Addendum i to Standard 90.1-2007. And, the lighting power allowance for building facades is further reduced in the advanced case to $50 \%$ of the $90.1-2007$ Addendum $i$ allowance because façade lighting is a purely decorative effect and should be eliminated or reduced in 
buildings attempting to save energy. As defined in Addendum i to 90.1-2007, buildings shall be classified under one of the lighting zones shown in Table 5.6 and shall follow all of the requirements for that specific zone.

Table 5.6. Lighting Zone Descriptions

\begin{tabular}{cl}
\hline $\begin{array}{c}\text { Lighting } \\
\text { Zone }\end{array}$ & \multicolumn{1}{c}{ Description } \\
\hline 1 & Developed areas of national parks, state parks, forest land, and rural areas \\
2 & $\begin{array}{l}\text { Areas predominantly consisting of residential zoning, neighborhood business districts, light } \\
\text { industrial with limited night time use and residential mixed use areas }\end{array}$ \\
3 & $\begin{array}{l}\text { All other areas } \\
\text { High activity commercial districts in major metropolitan areas as designated by the local } \\
\text { jurisdiction }\end{array}$ \\
\hline
\end{tabular}

Highway lodging buildings are typically found in lighting zones 2 and 3 (Table 5.6); therefore, exterior LPD recommendations in the design package are only for these two zones, as shown in Table 5.7. Allowed LPD are only for paved or improved areas, excluding grounds that do not require lighting. A base site allowance of $600 \mathrm{~W}$ for lighting zone 2 or $750 \mathrm{~W}$ for lighting zone 3 is added to the following allowable wattage. Considering that highway lodgings can be found in both lighting zones 2 and 3 , and lighting zone 3 has less stringent requirements, the LPD values for lighting zone 3 were used in the advanced building models for verifying the $50 \%$ energy savings target in a more conservative manner.

Table 5.7. Exterior Lighting Power Densities in the Advanced Models

\begin{tabular}{|c|c|c|c|}
\hline Surface Type & $\begin{array}{c}\text { Standard } 90.1-2004 \\
\mathrm{~W} / \mathrm{ft}^{2} \text { or } \mathrm{W} / \mathrm{lf} \\
\left(\mathrm{W} / \mathrm{m}^{2} \text { or } \mathrm{W} / \mathrm{m}\right)\end{array}$ & $\begin{array}{l}\text { Lighting Zone } 2 \\
\mathrm{~W} / \mathrm{ft}^{2} \text { or } \mathrm{W} / \mathrm{lf} \\
\left(\mathrm{W} / \mathrm{m}^{2} \text { or } \mathrm{W} / \mathrm{m}\right)\end{array}$ & $\begin{array}{l}\text { Lighting Zone } 3 \\
\mathrm{~W} / \mathrm{ft}^{2} \text { or } \mathrm{W} / \mathrm{lf} \\
\left(\mathrm{W} / \mathrm{m}^{2} \text { or } \mathrm{W} / \mathrm{m}\right)\end{array}$ \\
\hline Base allowance & $\begin{array}{l}5 \% \text { of the sum of the } \\
\text { individual exterior power } \\
\text { density }\end{array}$ & $600 \mathrm{~W}$ & $750 \mathrm{~W}$ \\
\hline Parking areas and drives & $0.15(1.61)$ & $0.06(0.65)$ & $0.10(1.08)$ \\
\hline Walkways less than 10 feet wide (lf) & $1.0(3.28)$ & $0.7(2.30)$ & $0.8(2.63)$ \\
\hline Walkways 10 feet wide or greater & $0.2(0.65)$ & $0.14(1.51)$ & $0.16(1.72)$ \\
\hline Entry canopies & $1.25(13.45)$ & $0.25(2.69)$ & $0.4(4.31)$ \\
\hline Facade (use wattage only for facade) & $0.2(2.15)$ & $0.05(0.54)$ & $0.075(0.81)$ \\
\hline
\end{tabular}

Similar to Table 4.4, which shows the baseline exterior lighting power calculations, Table 5.8 shows how the exterior lighting powers were derived for the advanced building models. 
Table 5.8. Advanced Exterior Lighting Power

\begin{tabular}{lccc}
\hline & & \multicolumn{2}{c}{ Lighting Zone 3 } \\
\cline { 3 - 4 } & \multicolumn{1}{c}{\begin{tabular}{c} 
Area \\
\multicolumn{1}{c}{ Building Area }
\end{tabular}} & $\begin{array}{c}\text { LPD } \\
\mathrm{W} / \mathrm{ft}^{2} \text { or W/lf } \\
\left(\mathrm{W} / \mathrm{m}^{2} \text { or } \mathrm{W} / \mathrm{m}\right)\end{array}$ & $\begin{array}{c}\text { Total Power } \\
(\mathrm{W})\end{array}$ \\
\hline Parking & $39,800(3698)$ & $0.1(1.08)$ & 3,980 \\
Walkway & $1,020(310)$ & $0.16(0.53)$ & 163 \\
$(10 \mathrm{ft}[3 \mathrm{~m}]$ wide or greater $)$ & $1,315(122)$ & $0.4(4.31)$ & 526 \\
Canopy & $2,155(200)$ & $0.16(1.08)$ & 345 \\
Pool & $20,800(1932)$ & $0.075(0.81)$ & 1,560 \\
Facade & & Subtotal & 6,574 \\
& & Base site allowance & 750 \\
& & Total & 7,324 \\
\hline
\end{tabular}

\subsubsection{Exterior Lighting Control}

On top of the measures of reduced exterior lighting power allowances, the design package recommends further reducing the parking area lighting energy use by using integrated bi-level control that reduces the power by $50 \%$ between midnight and $5 \mathrm{am}$. In addition, façade lighting that is installed was assumed to be programmed to turn off between the hours of midnight and $5 \mathrm{am}$ in the advanced models. In contrast, for the baseline buildings, exterior lights are fully energized whenever it is dark outside.

\subsubsection{Miscellaneous Equipment}

The miscellaneous equipment will not only increase the electrical energy use, but have impacts on the thermal loads as well. The EEMs for miscellaneous equipment address energy-efficient appliances and high efficiency laundry equipment. Advanced control and power management system are also recommended in this report.

\subsubsection{High-Efficiency Appliances and Laundry Equipment}

Following the AEDG-HL recommendations, the design package recommends using an absorption type of refrigerator in guest rooms and a high-efficiency washer, considering a significant amount of plug loads in lodging buildings are contributed by guest room appliances and laundry equipment.

Many highway lodging facilities are incorporating small refrigerators in guest rooms, either for in-room vending or as an amenity for guests. These refrigerators, while a relatively small load, run intermittently throughout the day to maintain cool temperatures within the cabinet. Conventional technology for this appliance utilizes a compression refrigeration cycle for cooling the refrigerator. Average power draw for this appliance is approximately $42 \mathrm{~W}$ continuously per year, as shown in Table 4.6, baseline plug load density calculations for guest rooms. A new technology using an electricdriven absorption refrigeration cycle reduces the average power draw for mini refrigerators to $33 \mathrm{~W}$, which was used in the advanced building models. Also, it was assumed that an ENERGY STAR labeled TV was used in the advanced buildings, while a conventional TV was used in baseline buildings. By using absorption-type refrigerator and ENERGY STAR labeled TV in the advanced building models, the 
plug load density was reduced to $0.97 \mathrm{~W} / \mathrm{ft}^{2}\left(10.44 \mathrm{~W} / \mathrm{m}^{2}\right)$ (Table 5.9), compared with $1.1 \mathrm{~W} / \mathrm{ft}^{2}(11.84$ $\mathrm{W} / \mathrm{m}^{2}$ ) for the baseline buildings.

Table 5.9. Plug Load Density Calculations for Guest Rooms in the Advanced Models

\begin{tabular}{lccccccc}
\hline & Peak & $\begin{array}{c}\text { Usage Length } \\
\text { Power } \\
\text { Equipment }\end{array}$ & $\begin{array}{c}\text { Fraction } \\
\text { Qmin/60) }\end{array}$ & $\begin{array}{c}\text { Quantity } \\
\text { Diversity }\end{array}$ & $\begin{array}{c}\text { Hourly } \\
\text { Piversity }\end{array}$ & $\begin{array}{c}\text { Power } \\
\text { (W) }\end{array}$ & Remarks \\
\hline Compact refrigerator & 1 & 33 & 1 & 1.00 & 1.00 & 33 & (b) \\
TV & 1 & 75 & 1 & 0.75 & 0.75 & 56 & (c) \\
Microwave & 1 & 400 & 0.08 & 0.25 & 0.02 & 8 & (a) \\
Hair dryer & 1 & 1500 & 0.17 & 0.25 & 0.04 & 63 & (d) \\
Iron & 1 & 1000 & 0.25 & 0.15 & 0.04 & 38 & (d) \\
Coffee maker & 1 & 1050 & 0.25 & 0.50 & 0.13 & 131 & (a) \\
Total $\left(\mathrm{W} / \mathrm{ft}^{2}\right)$ & & & & & & 0.97 & \\
\hline
\end{tabular}

(a) Data derived from the 2005 ASHRAE Handbook: Fundamentals Chapter 30 (ASHRAE 2005).

(b) The average annual energy consumption is $292 \mathrm{kWh} /$ year for a typical absorption type mini-refrigerator. Data is based on http://www.tradekey.com/product_view/id/466190.htm.

(c) Data derived from a report by Judy Roberson et al. at LBNL (Roberson et al. 2002).

(d) Web search.

For the appliances in other spaces, it was assumed that ENERGY STAR labeled products were used if available, which include computers, monitors, printers, copy machines, fax machines, water coolers, dish washers, and vending machines. A savings calculator is provided at the ENERGY STAR website ${ }^{13}$ for each category to estimate the percentage of energy savings in comparison with the corresponding conventional, non ENERGY STAR labeled products. These savings calculators were used to estimate the plug loads in the advanced models. The plug load peak power densities are summarized in Table 5.10.

Table 5.10. Plug Load Peak Power Density by Space Type in the Advanced Models

\begin{tabular}{lc}
\multicolumn{1}{c}{ Space Type } & $\begin{array}{c}\text { Plug Load Peak Density } \\
\mathrm{W} / \mathrm{ft}^{2}\left(\mathrm{~W} / \mathrm{m}^{2}\right)\end{array}$ \\
\hline Guest room & $0.97(10.43)$ \\
Lobby & $1.83(19.72)$ \\
Office & $0.71(7.66)$ \\
Meeting room & $0.57(6.18)$ \\
Exercise room & $1.53(16.51)$ \\
Employee lounge & $1.95(21.03)$ \\
Corridor/stairs/restroom/ & $0(0)$ \\
mechanical room/storage & \\
\hline
\end{tabular}

Water-conserving commercial washers consume approximately 0.45 gallons $(1.7 \mathrm{~L})$ of hot water per pound of laundry based on estimated hot water savings from high performance washers (Continental 2007). An even more important characteristic of commercial washers is the amount of water extracted

${ }^{13}$ Energy savings calculators for ENERGY STAR appliances are available at http://www.energystar.gov/ 
during the spin cycle. Extraction capability is a function of the G-force generated in the washer drum by the rotational speed of the drum. Standard washers generate a G-force of only about 85 G. Highperformance washers generate $\mathrm{G}$ forces over $300 \mathrm{G}$. For the high-performance washer, the retained water percentage is only $52.5 \%$, compared with $87.5 \%$ for conventional washers. The greater mass of water remaining in the laundry processed by the standard dryer must be removed by heat in the dryer. This savings is partially offset by the greater electrical consumption of the more powerful motors required to generate the high rotational speeds required to produce elevated $\mathrm{G}$ extractor forces. Typically, the electrical consumption of the high-performance washers is about $25 \%$ greater than that of the standard washer. Overall, however, savings from dryer energy consumption and hot water generation more than offset the additional electrical energy required for the washer motor. In general, because they are directfired appliances - sending both heated air and products of combustion through the bin containing the clothes to be dried - little efficiency differences are found among dryers. The key to reducing dryer energy consumption is to reduce the retained moisture content of the clothes before going through the dryer cycle. This measure recommends using washer/extractors that generate high $\mathrm{G}$ forces to reduce retained water percentage to $52.5 \%$, and that use only 0.45 gallons $(1.7 \mathrm{~L})$ of hot water per pound of laundry.

Based on the above discussions and research, it was assumed that a high-performance washer consumed $1.73 \mathrm{kWh} /$ cycle of electricity ( $25 \%$ more energy than a conventional washer); and dryers consumed $0.75 \mathrm{kWh} /$ cycle of electricity, and 0.41 therm/cycle $(12.03 \mathrm{kWh} /$ cycle $)$ of gas for the highway lodging building ( $40 \%$ less energy than using a conventional washer). These values were used in the advanced building models, as shown in Table 5.11.

Table 5.11. Laundry Equipment Hot Water and Energy Use Comparison

\begin{tabular}{|c|c|c|c|c|c|c|}
\hline \multirow[b]{2}{*}{ Washer Type } & \multicolumn{2}{|c|}{$\begin{array}{c}\text { Water Use per Pound of } \\
\text { Laundry }\end{array}$} & \multicolumn{4}{|c|}{ Gas Use } \\
\hline & $\begin{array}{c}\text { Total Water } \\
\text { gallon/lb } \\
(\mathrm{L} / \mathrm{kg})\end{array}$ & $\begin{array}{c}\text { Hot Water } \\
\text { gallon/lb } \\
(\mathrm{L} / \mathrm{kg})\end{array}$ & $\begin{array}{c}\% \text { Retained } \\
\text { Water }\end{array}$ & $\begin{array}{c}\text { Annual Water } \\
\text { Removed } \\
\text { lb (kg) }\end{array}$ & $\begin{array}{c}\text { Annual Gas } \\
\text { Use therms } \\
\text { (MW) }\end{array}$ & $\begin{array}{c}\text { Gas Use } \\
\text { therms/cycle } \\
\text { (kWh/cycle) }\end{array}$ \\
\hline Standard & $\begin{array}{c}3.0 \\
(25.03)\end{array}$ & $\begin{array}{c}1.2 \\
(10.01)\end{array}$ & $87.5 \%$ & $\begin{array}{c}221,327 \\
(100,393)\end{array}$ & $\begin{array}{l}3,995 \\
(117)\end{array}$ & $\begin{array}{c}0.68 \\
(19.93)\end{array}$ \\
\hline $\begin{array}{l}\text { High- } \\
\text { performance }\end{array}$ & $\begin{array}{c}2.25 \\
(18.78)\end{array}$ & $\begin{array}{c}0.45 \\
(3.75)\end{array}$ & $52.5 \%$ & $\begin{array}{l}132,796 \\
(60,236)\end{array}$ & $\begin{array}{l}2,397 \\
(70.25)\end{array}$ & $\begin{array}{c}0.41 \\
(12.03)\end{array}$ \\
\hline
\end{tabular}

\subsubsection{Advanced Control for Plug Loads}

Many guests do not turn off appliance such as TVs when leaving the rooms. Similar to the lighting control in guest rooms, occupancy-based energy management systems can interface with plug loads and turn off equipment when rooms are sensed to be unoccupied. In the advanced model, the plug load schedule was adjusted to simulate the occupancy-based control for plug loads in guest rooms. It was assumed that $50 \%$ of rented rooms have TVs on during unoccupied period for the baseline models and all TVs are turned off during unoccupied periods for the advanced models. Figure 5.2 shows the guest room plug load schedule for the baseline and advanced models. 


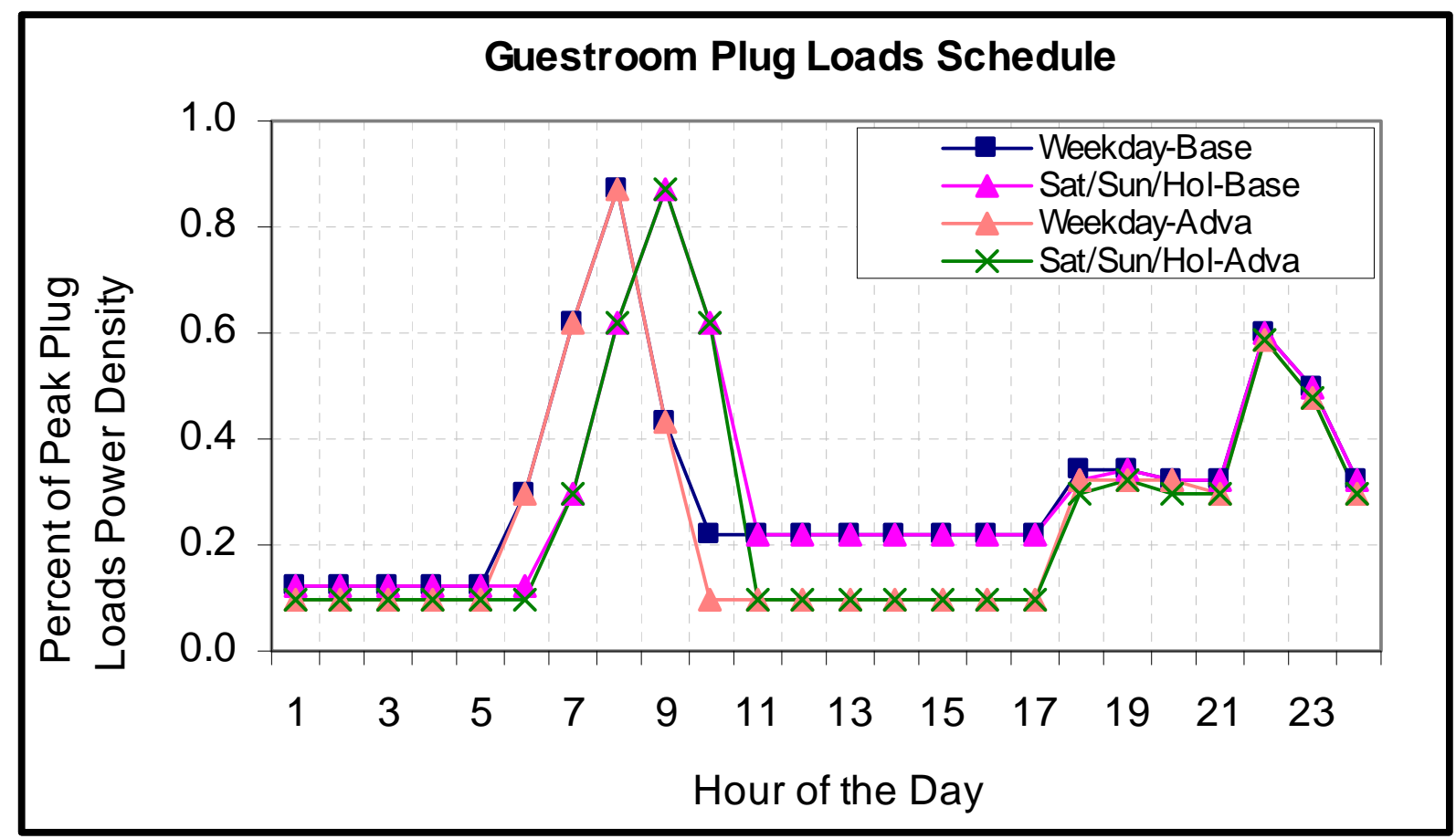

Figure 5.2. Guest Room Plug Loads Schedule

Plug strips with motion sensors and timer switches can be deployed in break rooms and offices to turn off plug loads such as vending machines, computer monitors, water coolers, and other equipment that plugs in. In the advanced model, the plug load controls were assumed for the office. The estimated energy reductions from implementing the plug loads control for office equipment in Table 5.12.

Estimating potential reductions from these strategies beyond those achieved by ENERGY STAR labeled products is based on how much of the time equipment is left on when not in use, the proportion of equipment that already has power management software, and estimated savings from several sources. This is a rough estimate; much is not known or up to date on actual current equipment energy usage (as opposed to connected power) and the use of controls in current new buildings for a baseline. The estimates in Table 5.12 were based on several sources (Sanchez et al. 2007; Rivas 2009; ENERGY STAR website). Overall, the control strategies reduced the total office plug energy usage by an additional $12 \%$ on top of high-efficiency office equipment. Reductions in energy for these strategies will not occur evenly throughout the day and will be largest during periods when occupancy is low or none. Figure 5.3 shows how the energy usage is captured by altering the schedule, particularly during low or no occupancy periods in the advanced models. 
Table 5.12. Estimated Energy Use Reduction in Plug Loads with Controls

\begin{tabular}{lc}
\hline \multicolumn{1}{c}{ Equipment } & \% Reductions in Plug Loads with \\
Controls \\
\hline Computers - desktop & $25.0 \%$ \\
Monitors - desktop - LCD & $7.5 \%$ \\
Water cooler & $20.0 \%$ \\
\hline
\end{tabular}

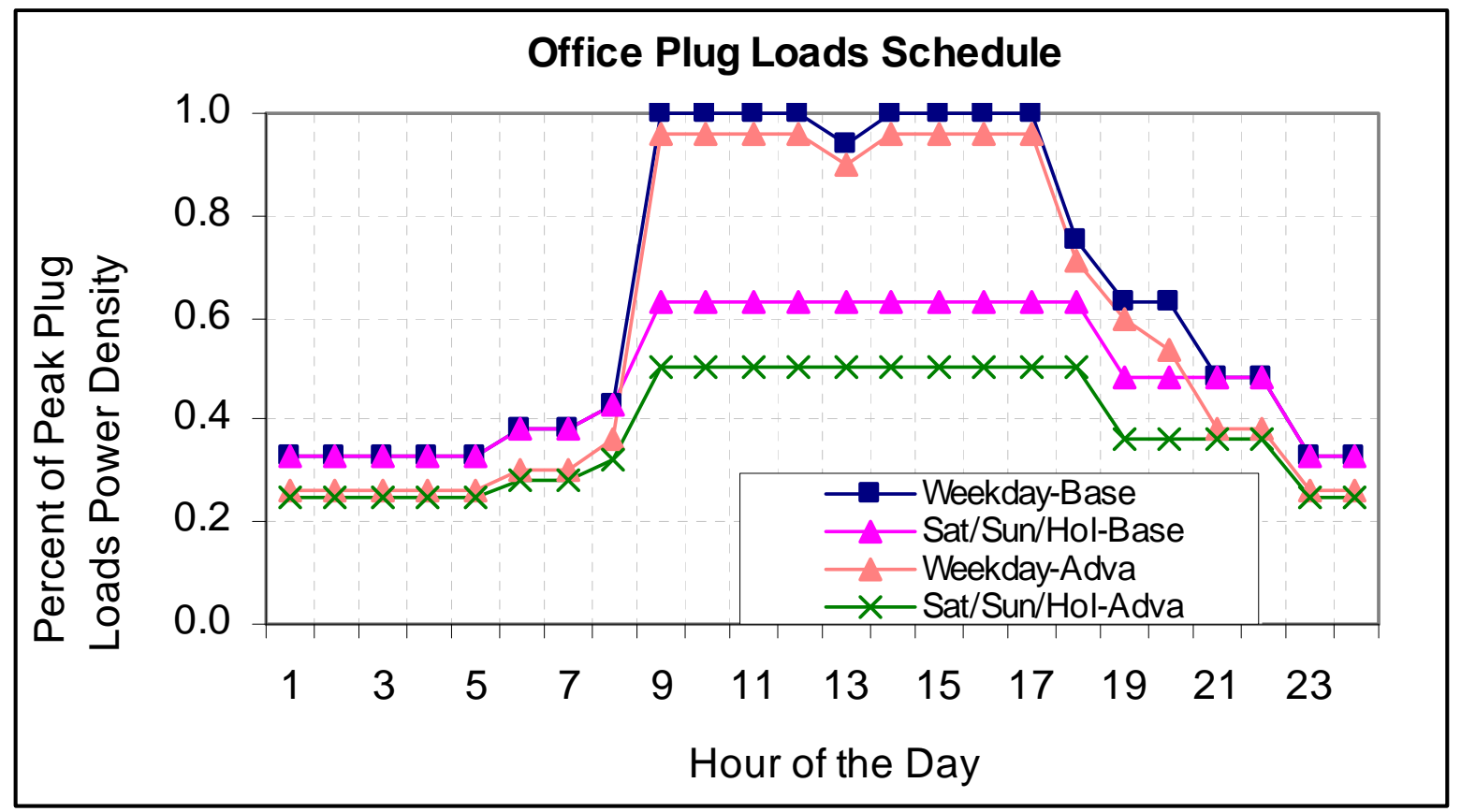

Figure 5.3. Office Plug Loads Schedule

\subsection{Advanced HVAC Systems}

To achieve the 50\% energy saving goal, PTACs and split air conditioners were replaced by a watersource heat pump (WSHP) system. This section describes the system setup and the related energy efficiency measures for the WSHP system. The EEMs for the HVAC systems include WSHPs, advanced thermostat controls, lower static pressure ductwork, economizer, motorized damper control, and energy recovery ventilators.

\subsubsection{HVAC System Type}

Initially, the analysis work for highway lodging proposed to achieve 50\% energy savings with PTHPs and split heat pump systems. It became clear the traditional heat pump systems along with the rest of the energy measures would not be adequate to reach $50 \%$ savings in all climate locations. WSHP systems were then proposed in the advanced models to replace the PTAC units and the split air conditioners used in the baseline models. The make-up air unit was also replaced with a WSHP type unit. WSHP units may be floor-mounted, console-style within the room, or suspended in the ceiling space. Each zone or space has one or more WSHP units, which are connected to a two-pipe water loop. The WSHP units 
either reject heat to or extract heat from the piping loop depending on whether they are cooling or heating the space. This system will therefore recover and redistribute heat when some of the units are in the heating mode and other units are in the cooling mode. This is an advantage particularly where there is an interior building core that requires year around cooling, and a perimeter zone where heating is required in the winter. The piping loop is usually kept between $60^{\circ} \mathrm{F}\left(15.6^{\circ} \mathrm{C}\right)$ and $90^{\circ} \mathrm{F}\left(32.2^{\circ} \mathrm{C}\right)$, which are the lower and higher limits for heat pump operation. The hydronic tempered water loop is typically equipped with a heat source, such as a boiler, to maintain the temperature of the circulating fluid above a preset minimum when the next heat extraction from the loop by the heat pumps might reduce that temperature to an unacceptable level. The circulating loop is also usually equipped with a heat rejection device such as a cooling tower or closed-circuit fluid cooler to maintain the circulating fluid temperature below a preset maximum when net heat addition to the loop might raise the temperature above operation levels. Table 5.13 summarizes the HVAC systems assumed for the advanced building models.

Table 5.13. Building HVAC Systems Comparison

\begin{tabular}{lll}
\hline \multicolumn{1}{c}{ Building Area } & Baseline HVAC System & Advanced HVAC System \\
\hline Guest rooms & $\begin{array}{l}\text { PTAC with electric resistance, } \\
\text { MAU, and central toilet } \\
\text { exhaust system }\end{array}$ & $\begin{array}{l}\text { WSHP, } \\
\text { MAU, and central toilet } \\
\text { exhaust system }\end{array}$ \\
Mechanical room and stairs & Unit heaters & Unit heaters \\
All other public spaces & Split air conditioner & WSHP \\
\hline
\end{tabular}

Similar to the system setup in the baseline models, a dedicated make-up air system was assumed to supply required outside air to the guest rooms in the advanced model. However, this system setup cannot be explicitly modeled in EnergyPlus because the WSHP module was categorized as system-level equipment, not as zone-level equipment, and it appears that EnergyPlus cannot model two systems serving one zone. Therefore, in the advanced models, the ventilation air was supplied through individual WSHP units as a work-around solution.

Another issue with modeling the WSHP system is the WSHP sizing methodology. In EnergyPlus (Version 3.0), the performance of WSHP cooling and heating coils are represented by a set of parameters that describe the operating conditions of the heat pump's components. These parameters are generated from the manufacturer catalog data using parameter estimation or equation fit (Tang 2005). Because some of the equipment size-related parameters for the cooling and heating coil models, such as the rated water flow rate, only allow user-defined values and no program autosize is provided, consequently the cooling tower and boiler loop cannot be autosized for different climate locations. In the advanced models, the size of the boiler and cooling tower loop is not varied for different climate locations. This WSHP sizing issue should be further studied in future work to improve the sizing approach in EnergyPlus.

\subsubsection{High Efficiency HVAC Equipment}

In Standard 90.1-2004, equipment efficiencies for WSHPs are specified for three size categories. The design package recommends the cooling efficiency and heating efficiency at certain rated cooling and heating capacities based on the AHRI's Certified Equipment Database and California Energy 
Commission (CEC) Appliances Database, as summarized in Table 5.14. The CEC Appliances Database lists all appliances currently certified to the $\mathrm{CEC}$ by their manufacturers as meeting currently-applicable efficiency standards. Appliances listed in the CEC database either meet federal efficiency standards or, where there are no federal efficiency standards, meet CEC efficiency standards. Appendix D shows the WSHP performance parameters and coefficients used in the advanced models.

The advanced models also used a condensing gas-fired boiler with a thermal efficiency of $95 \%$ in the WSHP loop, which is achievable for many ENERGY STAR labeled boilers (EPA 2009).

Table 5.14. Advanced HVAC Equipment Efficiency

\begin{tabular}{|c|c|c|c|}
\hline HVAC Type & System Capacity & $\begin{array}{l}\text { Cooling Efficiency } \\
\text { (EER) }\end{array}$ & $\begin{array}{l}\text { Heating Efficiency } \\
\text { (COP) }\end{array}$ \\
\hline \multirow[t]{3}{*}{$\begin{array}{l}\text { Water-source } \\
\text { Heat pump }\end{array}$} & $\begin{array}{l}<17 \mathrm{kBtu} / \mathrm{h} \\
(<5.0 \mathrm{~kW})\end{array}$ & 14.7 & 5.2 \\
\hline & $\begin{array}{l}\geq 17 \mathrm{kBtu} / \mathrm{h} \text { and }<65 \mathrm{kBtu} / \mathrm{h} \\
(\geq 5.0 \mathrm{~kW} \text { and }<19.0 \mathrm{~kW})\end{array}$ & 17.6 & 5.9 \\
\hline & $\begin{array}{l}\geq 65 \mathrm{kBtu} / \mathrm{h} \text { and }<135 \mathrm{kBtu} / \mathrm{h} \\
(\geq 19.0 \mathrm{~kW} \text { and }<39.6 \mathrm{~kW})\end{array}$ & 16.0 & 5.0 \\
\hline Boiler & All capacities & - & $95 \% \mathrm{E}_{\mathrm{t}}$ \\
\hline Unit heater & All capacities & - & $100 \% \mathrm{E}_{\mathrm{t}}$ \\
\hline
\end{tabular}

The improved motor efficiency for fans is based on the premium-efficiency motors initiative launched by the Consortium for Energy Efficiency (CEE 2003). Table 5.15 lists the motor efficiency requirement together with the corresponding nameplate motor horsepower. The values in the table assume enclosed motors operating at 1,800 RPM.

Table 5.15. Improved Motor Efficiency

\begin{tabular}{lccccccccccccc}
\hline $\begin{array}{l}\text { Motor hp } \\
(\mathrm{kW})\end{array}$ & $\begin{array}{c}1 \\
(0.7)\end{array}$ & $\begin{array}{c}2 \\
(1.5)\end{array}$ & $\begin{array}{c}5 \\
(3.7)\end{array}$ & $\begin{array}{c}10 \\
(7.5)\end{array}$ & $\begin{array}{c}15 \\
(11.2)\end{array}$ & $\begin{array}{c}20 \\
(14.9)\end{array}$ & $\begin{array}{c}30 \\
(22.4)\end{array}$ & $\begin{array}{c}(29.8) \\
(37.3)\end{array}$ & $\begin{array}{c}(44.7) \\
(93.2)\end{array}$ & $\begin{array}{c}(112) \\
(149)\end{array}$ \\
\hline $\begin{array}{l}\text { Efficiency } \\
(\%)\end{array}$ & 85.5 & 86.5 & 89.5 & 91.7 & 92.4 & 93 & 93.6 & 94.1 & 94.5 & 95 & 95.4 & 95.8 & 96.2 \\
\hline
\end{tabular}

\subsubsection{Advanced Thermostat Control}

Having a setback temperature for unoccupied periods during the heating season or setup temperature during the cooling season will help to save energy. In guest rooms, limiting conditioning during unoccupied periods can save significant amounts of energy in most climate zones. The design package recommends installing guest room occupancy-based energy management systems to manage the guest room air-conditioning system for occupied and unoccupied time periods. The guest room thermostat automatically reverts to unoccupied set points (usually $4^{\circ} \mathrm{F}\left[2.2^{\circ} \mathrm{C}\right]$ from set point) when the passive infrared (PIR) sensor in conjunction with the door switch determines that the room is indeed unoccupied. Therefore, for rented guest rooms during unoccupied period, typically from 9 am to $4 \mathrm{pm}$, the thermostat 
set points were assumed to be $66^{\circ} \mathrm{F}\left(18.9^{\circ} \mathrm{C}\right)$ for heating and $74^{\circ} \mathrm{F}\left(23.3^{\circ} \mathrm{C}\right)$ for cooling; the same set points were applied to vacant (unrented) guest rooms.

Time-of-day scheduling is useful when it is known which portions of the building public space will have reduced occupancy. Setback and setup controls were adopted for the meeting room, employee lounge and exercise room, which were usually unoccupied during night time. In the advanced building models, the heating set point of $65^{\circ} \mathrm{F}\left(18.3^{\circ} \mathrm{C}\right)$ and the cooling set point of $80^{\circ} \mathrm{F}\left(26.7^{\circ} \mathrm{C}\right)$ were assumed during night time for the meeting room, employee lounge and exercise room.

\subsubsection{Lower Static Pressure Ductwork}

To quantify the potential energy savings from the recommended improved ductwork design (low friction rate) in the analysis, the supply fan external static pressure drop for the MAU system in the prototype was re-calculated, based on a maximum ductwork friction rate no greater than $0.08 \mathrm{in} .(0.2 \mathrm{~mm})$ per 100 linear feet $(30.5 \mathrm{~m})$ of duct run. In addition, 0.75 in. w.c. $(187 \mathrm{~Pa})$ of static pressure was added to the supply fan to account for the additional pressure drop over the energy recovery ventilator (ERV), as described in Section 5.3.7. The internal static pressure for the WSHP type outdoor air unit was slightly lower than the baseline unit as shown in Table 5.16. In summary, total fan static pressure of the MAU was increased from 1.55 in. w.c. (386 Pa) for the baseline system to 1.95 in. w.c. (486 Pa) for the advanced system due to the additional pressure drop from ERV. The total fan power for the split systems in the advanced large prototype models was re-calculated following the same procedure as described in Section 4.3.6.

Table 5.16. Total Fan Static Pressure Drops Calculations for the Advanced MAU System

\begin{tabular}{|c|c|}
\hline Component & $\begin{array}{c}\text { Make-Up Air Unit } \\
@ 3500 \mathrm{cfm}\left(1.65 \mathrm{~m}^{3} / \mathrm{s}\right)\end{array}$ \\
\hline \multicolumn{2}{|c|}{ Internal Static Pressure (inches water column [Pa]) ${ }^{(\mathrm{a})}$} \\
\hline & $0.71(176.9)$ \\
\hline \multicolumn{2}{|c|}{ External Static Pressure (inches water column [Pa]) ${ }^{(\mathrm{c})}$} \\
\hline Diffuser & $0.05(12.5)$ \\
\hline Supply ductwork $^{(\mathrm{d})}$ & $0.19(47.3)$ \\
\hline ERV & $0.75(186.8)$ \\
\hline Fan outlet transition & $0.2(49.8)$ \\
\hline Subtotal & $0.44(109.6)$ \\
\hline $10 \%$ Safety factor & $0.04(10.0)$ \\
\hline Subtotal & $1.24(296.1)$ \\
\hline Total static pressure drops & $1.95(485.7)$ \\
\hline \multicolumn{2}{|c|}{$\begin{array}{l}\text { (a) Internal static pressure drops were derived from ClimateMaster outdoor air unit selection } \\
\text { spreadsheet, } 2009 \text {. }\end{array}$} \\
\hline \multicolumn{2}{|c|}{ (b) Used average difference between the clean and dirty filters. } \\
\hline \multicolumn{2}{|r|}{ listed } \\
\hline \multicolumn{2}{|l|}{ (d) Used C } \\
\hline
\end{tabular}




\subsubsection{Motorized Damper Control}

Motorized damper control can save significant energy, especially in cold climates when the unit may re-circulate air to maintain setback temperature during the unoccupied period and the cold outdoor air has to be heated by the unit if no motorized damper is employed. It also helps to control the excess humid outdoor air introduced into the building during off hours in hot and humid climates.

As described in Section 4, Standard 90.1-2004 does not require motorized dampers to control the outdoor air intake during off hours in systems with a design outdoor air intake or exhaust capacity of $300 \mathrm{cfm}\left(0.144 \mathrm{~m}^{3} / \mathrm{s}\right)$ or less. The design package includes use of motorized dampers to prevent outdoor air from entering during unoccupied periods. In the advanced model, outside air intake was turned off by the central energy management system when rooms are not rented. The systems serving the meeting room, exercise room and employee lounge, which are usually not in use during night time, were also assumed to be equipped with motorized dampers. For all the other public spaces and guest rooms, the ventilation air was supplied to the spaces continuously. To simulate the motorized damper control, hourly outdoor ventilation air schedules were modified to follow a two-step control strategy: 1) during the occupied hours, maintain the outdoor air damper at the minimum intake position, or modulate $100 \%$ open if the system operates in the economizer mode; 2) during unoccupied (off) hours, automatically close the outdoor air damper to reduce unnecessary outside air intake into the building.

\subsubsection{Air Side Economizer}

Following the recommendation in the AEDG-HL Guide, the design package recommends lowering the capacity threshold for air economizers from $65,000 \mathrm{Btu} / \mathrm{h}(19,050 \mathrm{~W})$ to $54,000 \mathrm{Btu} / \mathrm{h}(15,830 \mathrm{~W})$ for climate zone 3 through 8 . All of the WSHP units serving the guest rooms are below this threshold and air side economizers are not required. For the WSHP units serving the public spaces, some are large enough to require economizers, based on the zone served and climate. Same as the baseline assumption, the advanced building models assumed that the economizer high limit shutoff was controlled by differential dry bulb temperature except for zones $3 \mathrm{a}$ and $4 \mathrm{a}$ where fixed dry bulb temperature control is used and differential dry bulb temperature control is prohibited.

\subsubsection{Energy Recovery Ventilator}

Energy recovery ventilators can provide an energy-efficient means to deal with the latent and sensible outdoor air cooling loads during peak summer conditions. It can also reduce the required heating of outdoor air in cold climates. In cold climates, make-up air for continuous toilet exhaust from guest rooms with little internal heat gains can require significant energy consumption for space heating. Heat recovery can reduce this heat loss significantly, tempering energy requirements for outdoor air heat. Exhaust air energy recovery can be provided through a separate ERV that conditions the outdoor air before entering the air-conditioning or heat pump unit, an energy recovery unit that adds on to air-conditioning or heat pump unit, or an air-conditioning or heat pump unit with the integrated energy recovery unit. For lodging guest rooms, heat recovery can be provided between a central toilet exhaust system and a central ventilation air supply system. Offsetting the savings from the ERV is an increase in fan energy required to overcome the additional static pressure of the device and the parasitic energy from the enthalpy wheel rotation. 
The design package recommends using exhaust air ERVs for the make-up air system and the systems serving the public spaces. In the ERV model, it was assumed that the ERV had a sensible effectiveness of $75 \%$ and a latent effectiveness of $70 \%$ based on manufacturers' catalogues. For the MAU system and split systems that were modeled with the ERVs, an additional 0.75 in. w.c. (187 Pa) of static pressure was added to the system supply fans to account for the additional pressure drop over the ERV (Table 5.16), as well as additional $200 \mathrm{~W}$ auxiliary power to rotate the energy recovery wheel. As discussed in Section 5.3.1, the MAU system cannot be explicitly modeled; the associated pressure drop was added to the individual WSHP unit to approximately capture the additional fan energy use of the make-up air system. The air temperature after the enthalpy wheel is controlled to avoid overheating of the outdoor air. This was achieved in EnergyPlus with an outdoor air pretreat set point manager. This set point manager determines the desired temperature in the outdoor air stream by accounting for the mixed air set point and the mixing air conditions. The frost control was achieved by monitoring the temperature of the secondary air leaving the enthalpy wheel. If the exhaust air temperature is below the minimum set point $35^{\circ} \mathrm{F}$ $\left(1.7^{\circ} \mathrm{C}\right)$, the enthalpy wheel rotation will slow down with reduced heat exchanger effectiveness.

\subsection{Service Water Heating}

Service water heating constitutes a significant fraction of the total energy usage of lodging facilities in all climate zones. Great energy savings can be identified by examining each of the components that provide the heated water and control its use. Following the AEDG-HL Guide, the SWH recommendations in the design package contain higher-efficiency water heaters, hot water usage reduction technologies and drain waste heat recovery. In addition to the laundry drain waste heat recovery recommended in the AEDG-HL Guide, this design package also recommends recovering waste heat from guest room shower drains because shower hot water use consumes a great portion of the energy.

\subsubsection{High Efficiency Water Heater}

Condensing water heaters are recommended in the design package; therefore, $E_{t}$ of $95 \%$ was assumed in the advanced building models, corresponding to the heat input ratio (HIR) of 1.05.

\subsubsection{Hot Water Usage Reduction}

The least expensive means of reducing service water heating energy consumption is by reducing service hot water consumption. In the advanced model, it was assumed that lower flow shower heads can reduce hot water demand during showers from approximately 1.8 gallon per minute $(\mathrm{gpm})(0.114 \mathrm{~L} / \mathrm{s})$ to less than $1.5 \mathrm{gpm}(0.095 \mathrm{~L} / \mathrm{s})$. Lower flow lavatory faucets can produce similar hot water usage reductions for each lavatory. It was assumed using low flow shower heads and faucets can yield an average of $20 \%$ reduction in hot water use compared with the baseline system. This resulted in 11.2 gallon/day-room (42 L/day-room) for guest room hot water usage. Furthermore, water-conserving commercial washers consume approximately 0.45 gallons $(1.7 \mathrm{~L})$ of hot water per pound of laundry based on estimated hot water savings from high performance washers, which results in about $62.5 \%$ hot water use reduction compared with the baseline models. 


\subsubsection{Drain Waste Heat Recovery}

Potable water supply temperature to buildings in winter in cold climates can be extremely low, often below $50^{\circ} \mathrm{F}\left(10^{\circ} \mathrm{C}\right)$. Drain waste heat recovery units can raise the temperature of cold water supply, thus significantly reducing the energy needed to heat cold water. In the advanced models, it was assumed heat recovery was applied to both shower and laundry. Typical shower drain heat recovery units are only applicable to multi-story buildings or buildings with basements because they require a full story of vertical drop for the integral shower drain stack heat exchanger. In the highway lodging prototype, it was assumed that the shower drain heat recovery units were installed to recover heat from the second to fourth floor shower drain, and no heat was recovered from the first floor because of the lack of headroom for installing the recovery units for the first floor. Heat recovery units can transfer heat to the cold water supply to the washer/shower, or to the make-up water to the water heater, or to both. Either approach can significantly reduce water heating energy consumption in cold climates. Studies show that preheating both cold water streams can save about $10 \sim 30 \%$ more energy than pre-heating only the cold water supply to the washer/shower or only the make-up water to the water heater (DOE 2005). Therefore, in the advanced building models, it was assumed that the heat recovery units pre-heated both cold water streams.

A commercially available device that utilizes this technology is the Gravity-Film-Heat Exchanger (GFX) device developed by WaterFilm Energy, Inc. ${ }^{14}$ The device is typically installed vertically in the plumbing system. As waste hot water flows down through the vertical pipe wrapped with GFX copper tubing, the waste water's heat energy is transferred through the copper pipe and tubing to the incoming cold water. There is no pump and no storage tank needed for the device, and it uses no electricity, so there is no operating cost. The GFX is most closely approximated with the counter-flow heat exchanger. To simulate the performance of GFX devices, the EnergyPlus program requires inputting heat transfer coefficient (UA value) of GFX. As shown in Table 5.17, the UA was calculated using Logarithmic Mean Temperature Difference (LMTD) method based on the published performance data for GXF devices used for laundry drain water (model PS4-60) ${ }^{15}$ and shower drain water (model G3-60) ${ }^{16}$.

\footnotetext{
${ }^{14}$ http://gfxtechnology.com.

${ }_{15}$ The performance data can be obtained from: http://gfxtechnology.com/T-C.pdf.

${ }^{16}$ The performance data can be obtained from: Zaloum, C., M. Lafrance and J. Gusdorf, Drain Water Heat Recovery Characterization and Modeling Final Draft, Sustainable Buildings and Communities, Natural Resources Canada. 2007.
} 
Table 5.17. Gravity-Film-Heat-Exchanger Performance Data for Model PS4-60 and Model G3-60

\begin{tabular}{|c|c|c|c|c|c|c|c|c|}
\hline Model & $\begin{array}{c}\text { Water Flow } \\
\text { Rate GPM } \\
\left(\mathrm{m}^{3} / \mathrm{s}\right)\end{array}$ & $\begin{array}{c}\mathrm{EWT}_{\mathrm{c}}{ }^{\circ} \\
\mathrm{F}\left({ }^{\circ} \mathrm{C}\right)\end{array}$ & $\begin{array}{c}\mathrm{LWT}_{\mathrm{c}}{ }^{\circ} \\
\mathrm{F}\left({ }^{\circ} \mathrm{C}\right)\end{array}$ & $\begin{array}{l}\mathrm{EWT}_{\mathrm{h}}{ }^{\circ} \\
\mathrm{F}\left({ }^{\circ} \mathrm{C}\right)\end{array}$ & $\begin{array}{c}\mathrm{LWT}_{\mathrm{h}}{ }^{\circ} \\
\mathrm{F}\left({ }^{\circ} \mathrm{C}\right)\end{array}$ & $\begin{array}{c}\mathrm{Q} \\
\mathrm{Btu} / \mathrm{h}(\mathrm{W})\end{array}$ & $\begin{array}{c}\mathrm{LMTD}^{\circ} \\
\mathrm{F}\left({ }^{\circ} \mathrm{C}\right)\end{array}$ & $\begin{array}{c}\text { UA } \\
\text { Btu/ } /{ }^{\circ} \mathrm{F} \cdot \mathrm{h} \\
(\mathrm{W} / \mathrm{K})\end{array}$ \\
\hline PS4-60 & $10^{(\mathrm{a})}(0.00063)$ & $\begin{array}{c}60 \\
(15.5)\end{array}$ & $\begin{array}{c}77.5 \\
(25.3)\end{array}$ & $\begin{array}{c}95 \\
(35.0)\end{array}$ & $\begin{array}{c}79.5 \\
(26.4)\end{array}$ & $\begin{array}{c}77,548 \\
(22,728)\end{array}$ & $\begin{array}{c}18.5 \\
(-7.5)\end{array}$ & $4,196(2,210)$ \\
\hline G3-60 & $\begin{array}{c}2.75^{(\mathrm{b})} \\
(0.00017)\end{array}$ & $\begin{array}{c}46.8 \\
(8.22)\end{array}$ & $\begin{array}{c}80.8 \\
(27.1)\end{array}$ & $\begin{array}{l}104.7 \\
(40.4)\end{array}$ & $\begin{array}{c}80.8 \\
(27.1)\end{array}$ & $\begin{array}{l}31,502 \\
(9.233)\end{array}$ & $\begin{array}{c}28.7 \\
(-1.8)\end{array}$ & $1,099(579)$ \\
\hline $\begin{array}{l}\text { (a) } 10 \mathrm{gl} \\
\text { (b) } 2.75 \\
E W T_{c}=\mathrm{c} \\
L W T_{c}=\mathrm{c} \\
E W T_{h}=\mathrm{d} \\
L W T_{h}=\mathrm{d} \\
Q=U A>\end{array}$ & $\begin{array}{l}\mathrm{n}\left(0.00063 \mathrm{~m}^{3} / \mathrm{s}\right) \\
\left.0.00017 \mathrm{~m}^{3} / \mathrm{s}\right) \text { gpr } \\
\text { ld water entering } \\
\text { ld water leaving } \mathrm{t} \\
\text { ain waste water e } \\
\text { ain waste water le } \\
\text { LMTD }\end{array}$ & $\begin{array}{l}\text { ld and } 10 \\
\text { shower di } \\
\text { mperatur } \\
\text { aperature, } \\
\text { ering tem } \\
\text { ing temp }\end{array}$ & $\begin{array}{l}\text { pm }(0.000 \\
\text { in at } 105^{\circ} \mathrm{F} \\
{ }^{\circ} \mathrm{F}\left({ }^{\circ} \mathrm{C}\right) \text {. } \\
\mathrm{F}\left({ }^{\circ} \mathrm{C}\right) \text {. } \\
\text { rature, }{ }^{\circ} \mathrm{F} \\
\text { ature, }{ }^{\circ} \mathrm{F} \text {. }\end{array}$ & $\begin{array}{l}\left.3 \mathrm{~m}^{3} / \mathrm{s}\right) \mathrm{p} \\
\left(40.6^{\circ} \mathrm{C}\right) \\
\left.{ }^{\circ}\right) .\end{array}$ & $\begin{array}{l}\text { water at } 9 \\
\text { mperature }\end{array}$ & (1) & 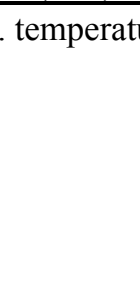 & \\
\hline \multicolumn{9}{|c|}{$L M T D=\underline{\left[\left(E W T_{h}-L W T_{c}\right)-\left(L W T_{h}-E W T_{c}\right)\right]}$} \\
\hline
\end{tabular}




\subsection{Cost Effectiveness Analysis}

Cost of energy measures is as relevant as savings. Based on DOE's goal of achieving "marketable" net-zero energy commercial buildings by 2025 , which necessitates low whole-building incremental costs, there is a strong interest in having information about the additional costs necessary to meet the recommended energy performance levels. The cost data provided in this report is intended to represent a reasonable estimate of the incremental costs for an energy efficient small hotel based on the small hotel prototype used for performing the energy simulations. This analysis uses incremental costs as the basis of comparison to help offset some of the biases in cost data when the cost data is deemed to be either routinely high or routinely low. For example, cost data from R.S. Means is generally considered to be a bit high in absolute value by consulting engineers who frequently use R.S. Means data as a method of quick estimation for budgeting purposes. On the other side, the cost data from a major hotel chain might be low in absolute value as a result of the volume buying power of the hotel chain. Using differences between the baseline and the advanced energy features costs (i.e., incremental costs), whether absolutely high or low, may result in costs that are more representative of the actual incremental cost seen in the industry.

The recommended energy efficiency measures have an average simple payback of 11.3 years and vary from 9.6 to 15.9 years. Actual project costs will vary, but the cost-effectiveness analysis does suggest that $50 \%$ energy savings can be achieved for new highway lodging buildings with a reasonable added cost for this level of energy cost savings.

\subsection{Basis for Incremental Energy Savings Measure Costs}

The costs for various energy savings measures are developed as incremental costs based on the difference between the costs for the baseline measure and the costs for the energy savings measure. The incremental costs may be based on a per unit cost, such as costs per square foot of wall area, or a per building cost, such as the cost of a single air-conditioning unit that serves an entire building or section of a building. This approach requires that, for each measure, both the baseline cost and the energy savings measure cost must be developed or data must be explicitly available on incremental costs.

The highway lodging prototype building described in Section 3.0 and 4.0 was used as the basis to develop the cost data. Costs were developed for each of the efficiency measures used in the building, and then the measure costs were summed to get the overall cost premium for the building prototype. Table 6.1 summarizes the basis for estimating both the baseline and energy savings costs for each of the critical measures of the lodging prototype building. 
Table 6.1. Cost Calculation Method Summary

\begin{tabular}{|c|c|c|}
\hline Component & Cost Equation & Source \\
\hline Roof insulation & $\begin{array}{l}\text { Cost }=\text { Area of insulation } \times \text { cost/square foot } \\
\text { insulation, advanced minus baseline }\end{array}$ & $\begin{array}{l}\text { RS Means Building Construction } \\
\text { Cost Data } 2009\end{array}$ \\
\hline $\begin{array}{l}\text { Exterior wall } \\
\text { insulation }\end{array}$ & $\begin{array}{l}\text { Cost }=\text { Area of insulation } \mathrm{x} \text { cost/square foot } \\
\text { insulation, advanced minus baseline }\end{array}$ & $\begin{array}{l}\text { RS Means Building Construction } \\
\text { Cost Data } 2009\end{array}$ \\
\hline Slab insulation & $\begin{array}{l}\text { Cost }=\text { Area of insulation } \mathrm{x} \text { cost/square foot } \\
\text { insulation, advanced minus baseline }\end{array}$ & $\begin{array}{l}\text { RS Means Building Construction } \\
\text { Cost Data } 2009\end{array}$ \\
\hline Cool roof & $\begin{array}{l}\text { Cost }=\text { Area of roof membrane } \mathrm{x} \\
\text { cost/square foot insulation, advanced minus } \\
\text { baseline }\end{array}$ & AEDG-HL TSD (Jiang et al. 2008) \\
\hline Windows \& doors & $\begin{array}{l}\text { Cost }=\text { Area of windows } \mathrm{x} \text { cost/square foot } \\
\text { of window, advanced minus baseline }\end{array}$ & $\begin{array}{l}90.1 \text { Envelope Committee } \\
\text { supporting fenestration data in } \\
\text { progress }\end{array}$ \\
\hline Interior lighting & $\begin{array}{l}\text { Incremental costs of lighting, controls and } \\
\text { engineering }\end{array}$ & Seattle Lighting Lab - Michael Lane \\
\hline Exterior lighting & $\begin{array}{l}\text { Incremental costs of lighting, controls and } \\
\text { engineering }\end{array}$ & Seattle Lighting Lab - Michael Lane \\
\hline $\begin{array}{l}\text { Plug loads -mini- } \\
\text { fridge, laundry }\end{array}$ & $\begin{array}{l}\text { Cost }=\text { Equipment cost per unit } x \text { number of } \\
\text { units, advanced minus baseline }\end{array}$ & AEDG-HL TSD (Jiang et al. 2008) \\
\hline $\begin{array}{l}\text { PTAC and split } \\
\text { systems to WSHP } \\
\text { systems including pipe } \\
\text { distribution }\end{array}$ & $\begin{array}{l}\text { Costs per unit for systems advanced minus } \\
\text { baseline. Advanced WSHP piping added } \\
\text { cost (no baseline cost) from total cooling } \\
\text { tonnage }\end{array}$ & $\begin{array}{l}\text { RS Means Mechanical Cost Data } \\
2009\end{array}$ \\
\hline $\begin{array}{l}\text { Condensing boiler, } \\
\text { fluid cooler, pump }\end{array}$ & $\begin{array}{l}\text { Advance cost only, no baseline. Boiler cost } \\
\text { based on capacity, Btu/h. Fluid cooler and } \\
\text { pump system based on tons cooling. }\end{array}$ & $\begin{array}{l}\text { RS Means Mechanical Cost Data } \\
2009\end{array}$ \\
\hline $\begin{array}{l}\text { Energy recovery } \\
\text { ventilator }\end{array}$ & $\begin{array}{l}\text { Advanced cost only, cost per unit based on } \\
\text { air flow, cfm }\end{array}$ & $\begin{array}{l}\text { RS Means Mechanical Cost Data } \\
2009\end{array}$ \\
\hline $\begin{array}{l}\text { Advanced thermostat } \\
\text { controls }\end{array}$ & Advanced cost only, cost per room served & AEDG-HL TSD (Jiang et al. 2008) \\
\hline $\begin{array}{l}\text { Service water heating } \\
\text { including water heater } \\
\text { and heat recovery }\end{array}$ & $\begin{array}{l}\text { Cost }=\text { Water heater cost, advanced- } \\
\text { baseline plus cost for heat recovery. No } \\
\text { heat recovery in baseline }\end{array}$ & $\begin{array}{l}\text { Online AO Smith equipment, } \\
\text { www.vidavici.com }\end{array}$ \\
\hline
\end{tabular}




\subsection{Comparison of Incremental Costs to Baseline Costs for Construction}

Incremental costs were calculated using the methodology described in Section 6.1. Table 6.2 provides the incremental costs for the advanced energy measures.

Within the design and construction community, the quick evaluation of cost premiums versus the expected cost per square foot estimates may serve as a surrogate for cost effectiveness in many cases. The incremental cost per square foot above typical highway lodging construction costs is shown in Table 6.3. For example, the 2009 version of R.S. Means Construction Cost Data (R.S. Means 2009) indicates that for motels the median unit construction cost is $\$ 102 / \mathrm{ft}^{2}\left(\$ 1,100 / \mathrm{m}^{2}\right)$ with a lower quartile value of $\$ 70.50 / \mathrm{ft}^{2}\left(\$ 755 / \mathrm{m}^{2}\right)$ and an upper quartile value of $\$ 133.00 / \mathrm{ft}^{2}\left(\$ 1,434 / \mathrm{m}^{2}\right)$. The median unit construction cost was then adjusted based on a multiplier for the ratio of the prototype building (43,200 $\left.\mathrm{ft}^{2}\right)$ size to the typical R.S. Means building size $\left(40,000 \mathrm{ft}^{2}\right)$, yielding an adjusted median unit construction cost of $\$ 100.98 / \mathrm{ft}^{2}\left(\$ 1,087 / \mathrm{m}^{2}\right)$. First costs per square foot tend to be lower for larger buildings because of the combined effects of economies of scale for larger buildings, as well as the decreasing contribution of the exterior walls in larger buildings according to R.S. Means. Cost premiums are developed using the incremental costs for the energy savings measures in each climate zone.

To address the needs of this segment of the industry, the total incremental costs developed in Table 6.2 are compared to the median baseline construction costs to help evaluate the surrogate cost effectiveness of the guide for each of the climate zones. Table 6.3 provides this comparison. Note that in this table the median baseline construction cost estimates are shown with the Means Guide Construction Cost Data cost multipliers for the climate cities analyzed as part of the energy savings analysis (R.S. Means 2009). 
Table 6.2. Incremental Costs for Advanced Energy Measures

\begin{tabular}{|c|c|c|c|c|c|c|c|c|c|c|c|c|c|c|c|c|}
\hline Component & $\begin{array}{c}\text { 1A } \\
\text { Miami }\end{array}$ & $\begin{array}{c}2 \mathrm{~A} \\
\text { Houston }\end{array}$ & $\begin{array}{c}\text { 2B } \\
\text { Phoenix }\end{array}$ & $\begin{array}{c}\text { 3A } \\
\text { Attanta }\end{array}$ & $\begin{array}{c}\text { 3B-CA } \\
\text { Los Angeles }\end{array}$ & $\begin{array}{c}\text { 3B-other } \\
\text { Las Vegas }\end{array}$ & $\begin{array}{c}3 \mathrm{C} \\
\text { San Francisco }\end{array}$ & $\begin{array}{c}4 \mathrm{~A} \\
\text { Baltimore }\end{array}$ & $\begin{array}{c}4 \mathrm{~B} \\
\text { Albuquerque }\end{array}$ & $\begin{array}{c}4 C \\
\text { Seattle }\end{array}$ & $\begin{array}{c}5 \mathrm{~A} \\
\text { Chicago }\end{array}$ & $\begin{array}{c}\text { 5B } \\
\text { Denver }\end{array}$ & $\begin{array}{c}\text { 6A } \\
\text { Minneapolis }\end{array}$ & $\begin{array}{c}6 \mathrm{~B} \\
\text { Helena }\end{array}$ & $\begin{array}{c}7 \\
\text { Duluth }\end{array}$ & $\begin{array}{c}8 \\
\text { Fairbanks }\end{array}$ \\
\hline Roof Insulation & $\$ 9,612$ & $\$ 9,612$ & $\$ 9,612$ & $\$ 9,612$ & $\$ 9,612$ & $\$ 9,612$ & $\$ 9,612$ & $\$ 13,932$ & $\$ 13,932$ & $\$ 13,932$ & $\$ 13,932$ & $\$ 13,932$ & $\$ 13,932$ & $\$ 13,932$ & $\$ 18,252$ & $\$ 13,932$ \\
\hline Exterior Wall Insulation & $\$ 10,271$ & $\$ 14,228$ & $\$ 14,228$ & $\$ 19,058$ & $\$ 19,058$ & $\$ 19,058$ & $\$ 19,058$ & $\$ 19,542$ & $\$ 19,542$ & $\$ 19,542$ & $\$ 16,134$ & $\$ 16,134$ & $\$ 18,917$ & $\$ 18,917$ & $\$ 12,794$ & $\$ 11,551$ \\
\hline Cool Roof & \multicolumn{16}{|c|}{$\$ 7,884$} \\
\hline Windows & $\$ 11,766$ & $\$ 13,973$ & $\$ 13,973$ & $\$ 5,031$ & $\$ 5,031$ & $\$ 5,031$ & $\$ 16,777$ & $\$ 7,485$ & $\$ 7,485$ & $\$ 7,485$ & $\$ 14,066$ & $\$ 14,066$ & $\$ 14,066$ & $\$ 14,066$ & $\$ 14,767$ & $\$ 17,506$ \\
\hline Interior Lighting & \multicolumn{16}{|c|}{$\$ 4,224$} \\
\hline Exterior Lighting & \multicolumn{16}{|c|}{$(\$ 3,750)$} \\
\hline Plug Loads-mini-fridge,laundry & \multicolumn{16}{|c|}{$\$ 34,013$} \\
\hline $\begin{array}{l}\text { PTAC and split systems to } \\
\text { WSHP systems, piping }\end{array}$ & \multicolumn{16}{|c|}{$\$ 123,387$} \\
\hline WSHP boiler, fluid cooler, pump & \multicolumn{16}{|c|}{$\$ 76,670$} \\
\hline Energy Recovery & \multicolumn{16}{|c|}{$\$ 9,241$} \\
\hline Advanced Thermostat Controls & \multicolumn{16}{|c|}{$\$ 32,648$} \\
\hline $\begin{array}{l}\text { Service water heating including } \\
\text { water heater and heat recovery }\end{array}$ & \multicolumn{16}{|c|}{$\$ 48,780$} \\
\hline Sub-total & $\$ 364,747$ & $\$ 370,909$ & $\$ 370,909$ & $\$ 366,798$ & $\$ 366,798$ & $\$ 366,798$ & $\$ 378,544$ & $\$ 374,056$ & $\$ 374,056$ & $\$ 374,056$ & $\$ 377,228$ & $\$ 377,228$ & $\$ 380,011$ & $\$ 380,011$ & $\$ 378,909$ & $\$ 376,086$ \\
\hline Location Cost Index, \% (Means) & $90 \%$ & $88 \%$ & $89 \%$ & $90 \%$ & $108 \%$ & $106 \%$ & $124 \%$ & $93 \%$ & $90 \%$ & $104 \%$ & $115 \%$ & $95 \%$ & $110 \%$ & $90 \%$ & $102 \%$ & $121 \%$ \\
\hline TOTAL (with location adjustment & $\$ 329,366$ & $\$ 327,513$ & $\$ 330,109$ & $\$ 330,852$ & $\$ 397,243$ & $\$ 387,706$ & $\$ 468,638$ & $\$ 348,246$ & $\$ 335,902$ & $\$ 388,644$ & $\$ 433,435$ & $\$ 358,367$ & $\$ 417,252$ & $\$ 341,630$ & $\$ 388,003$ & $\$ 456,192$ \\
\hline
\end{tabular}


Table 6.3. Unit Cost Increase

\begin{tabular}{|c|c|c|c|c|c|c|c|c|c|}
\hline $\begin{array}{l}\text { Climate } \\
\text { Zone }\end{array}$ & City & $\begin{array}{l}\text { Incremental } \\
\text { Cost }\end{array}$ & $\begin{array}{c}\text { Unit Cost } \\
\text { Increase, } \\
\$ / f^{2} t^{2}\end{array}$ & $\$ / m^{2}$ & $\begin{array}{c}\text { Location } \\
\text { Adjusted } \\
\text { Baseline } \\
\text { Median Unit } \\
\text { Cost, \$/ft }{ }^{2}\end{array}$ & $\$ / m^{2}$ & $\begin{array}{c}\text { Advanced } \\
\text { Unit } \\
\text { Construction } \\
\text { Cost, } \$ / f^{2}{ }^{2}\end{array}$ & $\$ / m^{2}$ & $\begin{array}{c}\text { Unit Cost } \\
\text { Increase } \\
\text { Over Unit } \\
\text { Median } \\
\text { Baseline }\end{array}$ \\
\hline $1 \mathrm{~A}$ & Miami & $\$ 329,366$ & $\$ 7.62$ & $\$ 82.07$ & $\$ 91.18$ & $\$ 981.61$ & $\$ 98.81$ & $\$ 1,063.68$ & $8.4 \%$ \\
\hline $2 \mathrm{~A}$ & Houston & $\$ 327,513$ & $\$ 7.58$ & $\$ 81.61$ & $\$ 89.17$ & $\$ 959.86$ & $\$ 96.75$ & $\$ 1,041.48$ & $8.5 \%$ \\
\hline $2 \mathrm{~B}$ & Phoenix & $\$ 330,109$ & $\$ 7.64$ & $\$ 82.26$ & $\$ 89.87$ & $\$ 967.47$ & $\$ 97.51$ & $\$ 1,049.73$ & $8.5 \%$ \\
\hline $3 \mathrm{~A}$ & Atlanta & $\$ 330,852$ & $\$ 7.66$ & $\$ 82.44$ & $\$ 91.08$ & $\$ 980.52$ & $\$ 98.74$ & $\$ 1,062.96$ & $8.4 \%$ \\
\hline $3 \mathrm{~B}$ & Los Angeles & $\$ 397,243$ & $\$ 9.20$ & $\$ 98.99$ & $\$ 109.36$ & $\$ 1,177.27$ & $\$ 118.56$ & $\$ 1,276.26$ & $8.4 \%$ \\
\hline $3 \mathrm{~B}$ & Las Vegas & $\$ 387,706$ & $\$ 8.97$ & $\$ 96.61$ & $\$ 106.74$ & $\$ 1,149.01$ & $\$ 115.71$ & $\$ 1,245.62$ & $8.4 \%$ \\
\hline $3 \mathrm{C}$ & San Fran. & $\$ 468,638$ & $\$ 10.85$ & $\$ 116.78$ & $\$ 125.01$ & $\$ 1,345.77$ & $\$ 135.86$ & $\$ 1,462.55$ & $8.7 \%$ \\
\hline $4 \mathrm{~A}$ & Baltimore & $\$ 348,246$ & $\$ 8.06$ & $\$ 86.78$ & $\$ 94.01$ & $\$ 1,012.04$ & $\$ 102.07$ & $\$ 1,098.82$ & $8.6 \%$ \\
\hline 4B & Albuquerque & $\$ 335,902$ & $\$ 7.78$ & $\$ 83.70$ & $\$ 90.68$ & $\$ 976.17$ & $\$ 98.46$ & $\$ 1,059.87$ & $8.6 \%$ \\
\hline $4 \mathrm{C}$ & Seattle & $\$ 388,644$ & $\$ 9.00$ & $\$ 96.85$ & $\$ 104.92$ & $\$ 1,129.44$ & $\$ 113.91$ & $\$ 1,226.29$ & $8.6 \%$ \\
\hline $5 \mathrm{~A}$ & Chicago & $\$ 433,435$ & $\$ 10.03$ & $\$ 108.01$ & $\$ 116.03$ & $\$ 1,249.02$ & $\$ 126.06$ & $\$ 1,357.03$ & $8.6 \%$ \\
\hline $5 \mathrm{~B}$ & Denver & $\$ 358,367$ & $\$ 8.30$ & $\$ 89.30$ & $\$ 95.93$ & $\$ 1,032.70$ & $\$ 104.23$ & $\$ 1,122.00$ & $8.6 \%$ \\
\hline $6 \mathrm{~A}$ & Minneapolis & $\$ 417,252$ & $\$ 9.66$ & $\$ 103.98$ & $\$ 110.88$ & $\$ 1,193.58$ & $\$ 120.53$ & $\$ 1,297.56$ & $8.7 \%$ \\
\hline $6 \mathrm{~B}$ & Helena & $\$ 341,630$ & $\$ 7.91$ & $\$ 85.13$ & $\$ 90.78$ & $\$ 977.26$ & $\$ 98.69$ & $\$ 1,062.39$ & $8.7 \%$ \\
\hline 7 & Duluth & $\$ 388,003$ & $\$ 8.98$ & $\$ 96.69$ & $\$ 103.40$ & $\$ 1,113.14$ & $\$ 112.39$ & $\$ 1,209.83$ & $8.7 \%$ \\
\hline 8 & Fairbanks & $\$ 456,192$ & $\$ 10.56$ & $\$ 113.68$ & $\$ 122.49$ & $\$ 1,318.59$ & $\$ 133.05$ & $\$ 1,432.27$ & $8.6 \%$ \\
\hline
\end{tabular}

\subsection{Cost Effectiveness Calculations}

Cost effectiveness can be shown most directly by looking at the simple payback period for the energy savings measures recommended in the guide. In Table 6.4 simple payback values vary from 9.6 to 15.9 years, with an average of 11.3 years. The variability in payback results is due to differences in the location cost index for different climate cities as shown in Table 6.3 as well as energy savings and climate zone specific differences in the energy measures such as insulation values. The simple payback for each climate zone is calculated for the energy savings measures in aggregate by dividing the total incremental cost of the measures by the energy savings in dollars. Energy savings in dollars is calculated by using the EIA national average natural gas rate of $\$ 1.16 /$ therm and the national average electric rate of $\$ 0.0939 / \mathrm{kWh}^{1}$ These rates are the same ones being used by the SSPC 90.1 committee in developing the 2010 version of Standard 90.1.

\footnotetext{
${ }^{1}$ National average natural gas rate and electric rate are derived from the report Annual Energy Review 2006 by EIA. Last accessed at http://www.eia.doe.gov/emeu/aer/pdf/aer.pdf in October 2007.
} 
Table 6.4. Simple Payback Period

\begin{tabular}{clccccc}
\hline \multirow{2}{*}{$\begin{array}{c}\text { Climate } \\
\text { Zone }\end{array}$} & Climate City & $\begin{array}{c}\text { Incremental } \\
\text { First Cost }\end{array}$ & Electricity & Natural Gas & Total & $\begin{array}{c}\text { Simple } \\
\text { Payback } \\
\text { (Years) }\end{array}$ \\
\hline 1A & Miami & $\$ 329,366$ & $\$ 27,930$ & $\$ 5,235$ & $\$ 33,165$ & 9.9 \\
2A & Houston & $\$ 327,513$ & $\$ 26,472$ & $\$ 6,815$ & $\$ 33,286$ & 9.8 \\
2B & Phoenix & $\$ 330,109$ & $\$ 25,952$ & $\$ 5,751$ & $\$ 31,703$ & 10.4 \\
3A & Atlanta & $\$ 330,852$ & $\$ 25,503$ & $\$ 7,299$ & $\$ 32,802$ & 10.1 \\
3B & Los Angeles & $\$ 397,243$ & $\$ 23,114$ & $\$ 6,352$ & $\$ 29,466$ & 13.5 \\
3B & Las Vegas & $\$ 387,706$ & $\$ 23,604$ & $\$ 6,185$ & $\$ 29,789$ & 13.0 \\
3C & San Francisco & $\$ 468,638$ & $\$ 22,227$ & $\$ 7,247$ & $\$ 29,474$ & 15.9 \\
4A & Baltimore & $\$ 348,246$ & $\$ 25,148$ & $\$ 8,818$ & $\$ 33,966$ & 10.3 \\
4B & Albuquerque & $\$ 335,902$ & $\$ 22,716$ & $\$ 7,703$ & $\$ 30,420$ & 11.0 \\
4C & Seattle & $\$ 388,644$ & $\$ 22,588$ & $\$ 8,368$ & $\$ 30,957$ & 12.6 \\
5A & Chicago & $\$ 433,435$ & $\$ 25,369$ & $\$ 10,834$ & $\$ 36,203$ & 12.0 \\
5B & Denver & $\$ 358,367$ & $\$ 23,168$ & $\$ 9,173$ & $\$ 32,340$ & 11.1 \\
\hline 6A & Minneapolis & $\$ 417,252$ & $\$ 25,171$ & $\$ 13,464$ & $\$ 38,635$ & 10.8 \\
6B & Helena & $\$ 341,630$ & $\$ 23,286$ & $\$ 11,494$ & $\$ 34,780$ & 9.8 \\
\hline 7 & Duluth & $\$ 388,003$ & $\$ 25,501$ & $\$ 14,801$ & $\$ 40,302$ & 9.6 \\
\hline 8 & Fairbanks & $\$ 456,192$ & $\$ 25,364$ & $\$ 19,005$ & $\$ 44,370$ & 10.3 \\
\hline
\end{tabular}

\subsection{A Perspective on Costs for Advanced Buildings}

With the growth of activity in the high performance buildings market, there is a commensurate growth in the desire to understand the real costs to achieve these higher levels of energy performance in buildings. Any effort such as the one included in this document is inevitably faced with the challenges of finding good, credible sources of cost data, particularly when some of the more advanced measures are being considered. The reader will note that the sources for this work run the gamut of widely published data such as might be found in R. S. Means, engineering consulting firm and contractor budget estimates, code development sources such as the SSPC 90.1 Cost Database, or data found on websites and in testimonials. Clearly it would be desirable to have robust costs for all measures, collected in a consistent manner. Unfortunately this situation does not exist, and it is for this reason that identifying costs in a consistent and accurate manner is difficult to execute. 


\subsection{Recommendations and Energy Savings Results}

This section contains the final recommendations in this TSD report, as well as the energy savings results that are achieved as a result of applying these recommendations to the prototypical building. The recommendations are applicable for all highway lodging buildings within the scope of the study as a means of demonstrating the $50 \%$ energy savings. The authors recognize that there are other ways of achieving the $50 \%$ energy savings, and offer these recommendations in this report as "a way, but not the only way" of meeting the energy savings target. This analysis used Standard 90.1-2004 baseline or the same values as modeled for the baseline for items not regulated by the Standard or not recommended in this report.

The recommendations presented in this TSD are intended to serve as starting points for projectspecific analyses. The recommendations are not meant for specific design guidance for an actual project because of project-specific variations in economic criteria and energy design measures.

\subsection{Final Energy Savings Recommendations}

This section describes the final energy savings recommendations in the $50 \%$ design package. Each of the climate zone recommendation tables includes a set of common items arranged by building subsystem: envelope, lighting, HVAC, and service water heating (SWH). Recommendations are included for each item, or subsystem, by component within that subsystem. When a recommendation contains the designation "NR," then the authors are not providing a recommendation for this component or system. In these cases, the requirements of Standard 90.1-2004 or the local code (whichever is more stringent) will apply.

\subsubsection{Envelope Measures}

The envelope measures cover the range of assemblies for both the opaque and fenestration portions of the buildings. Opaque elements include the roof, walls, floors and slabs, as well as opaque doors.

Fenestration covers the vertical glazing (including glass doors). For some of the building elements, there are a number of components for which the design package provides recommendations.

Recommendations for each envelope component are contained in Table 7.1, and are organized by climate zone, ranging from the hot zone 1 to the very cold zone 8. Consistent with the movement from the hotter to colder zones, the insulation requirements (R-value) increase as the climates get colder, and corresponding thermal transmittance (U-factor) decreases. Control of solar loads is more important in the hotter, sunnier climates, and thus the solar heat gain coefficient tends to be more stringent (lower) in zone 1 and higher in zone 8 . 
Table 7.1. Final Energy Savings Recommendations - Building Envelope

\begin{tabular}{|c|c|c|c|c|c|c|c|c|c|}
\hline Item & Component & Zone 1 & Zone 2 & Zone 3 & Zone 4 & Zone 5 & Zone 6 & Zone 7 & Zone 8 \\
\hline \multirow{2}{*}{$\begin{array}{l}\text { Roof } \\
\text { (Insulation } \\
\text { entirely above } \\
\text { deck) }\end{array}$} & $\begin{array}{l}\text { R-value } \\
{ }^{\mathrm{o}} \mathrm{F} \cdot \mathrm{h} \cdot \mathrm{ft}^{2} / \text { Btu } \\
\left(\mathrm{K} \cdot \mathrm{m}^{2} / \mathrm{W}\right)\end{array}$ & $\begin{array}{c}\text { R-25 c.i. } \\
\text { (R-4.4 } \\
\text { c.i. })\end{array}$ & $\begin{array}{c}\text { R-25 c.i. } \\
\text { (R-4.4 } \\
\text { c.i. })\end{array}$ & $\begin{array}{c}\text { R-25 c.i. } \\
\text { (R-4.4 } \\
\text { c.i. })\end{array}$ & $\begin{array}{l}\text { R-30 c.i. } \\
\text { (R-5.3 } \\
\text { c.i.) }\end{array}$ & $\begin{array}{l}\text { R-30 c.i. } \\
\text { (R-5.3 } \\
\text { c.i.) }\end{array}$ & $\begin{array}{c}\text { R-30 c.i. } \\
\text { (R-5.3 } \\
\text { c.i.) }\end{array}$ & $\begin{array}{c}\text { R-35 c.i. } \\
\text { (R-6. } 2 \\
\text { c.i.) }\end{array}$ & $\begin{array}{c}\text { R-35 c.i. } \\
\text { (R-6.2 c.i.) }\end{array}$ \\
\hline & SRI & 78 & 78 & 78 & NR & NR & NR & NR & NR \\
\hline $\begin{array}{l}\text { Exterior walls } \\
\text { (mass wall) }\end{array}$ & \begin{tabular}{|l} 
R-vlue \\
${ }^{o} \mathrm{~F} \cdot \mathrm{h} \cdot \mathrm{ft}^{2} / \mathrm{Btu}$ \\
$\left(\mathrm{K} \cdot \mathrm{m}^{2} / \mathrm{W}\right)$
\end{tabular} & $\begin{array}{c}\text { R-5.7 c.i. } \\
\text { (R-1.0 } \\
\text { c.i. })\end{array}$ & $\begin{array}{c}\text { R-7.6 c.i. } \\
\text { (R-1.3 } \\
\text { c.i. })\end{array}$ & $\begin{array}{c}\text { R-11.4 c.i. } \\
\text { (R-2.0 } \\
\text { c.i.) }\end{array}$ & $\begin{array}{c}\text { R-13.3 c.i. } \\
\text { (R-2.3 } \\
\text { c.i.) }\end{array}$ & $\begin{array}{c}\text { R-19.5 c.i. } \\
\text { (R-3.4 } \\
\text { c.i.) }\end{array}$ & $\begin{array}{c}\text { R-19.5 c.i. } \\
\text { (R-3.4 } \\
\text { c.i.) }\end{array}$ & $\begin{array}{c}\text { R-19.5 c.i. } \\
\text { (R-3.4 } \\
\text { c.i. })\end{array}$ & $\begin{array}{l}\text { R-19.5 c.i. } \\
\text { (R-3.4 c.i.) }\end{array}$ \\
\hline $\begin{array}{l}\text { Slabs } \\
\text { (unheated) }\end{array}$ & $\begin{array}{l}\text { R-value } \\
\mathrm{ft} \cdot{ }^{\circ} \mathrm{F} \cdot \mathrm{h} / \mathrm{Btu} \\
\left(\mathrm{K} \cdot \mathrm{m}^{2} / \mathrm{W}\right)\end{array}$ & NR & NR & $\begin{array}{l}\text { R-10 for } \\
24 \text { in. } \\
\text { (R-1.8 for } \\
0.61 \mathrm{~m} \text { ) }\end{array}$ & $\begin{array}{l}\mathrm{R}-15 \text { for } \\
24 \text { in. } \\
\text { (R-2.6 for } \\
0.61 \mathrm{~m})\end{array}$ & $\begin{array}{l}\text { R-20 for } \\
24 \text { in. } \\
\text { (R-3.5 for } \\
0.61 \mathrm{~m} \text { ) }\end{array}$ & $\begin{array}{l}\mathrm{R}-20 \text { for } \\
48 \text { in. } \\
\text { (R-3.5 for } \\
1.22 \mathrm{~m} \text { ) }\end{array}$ & $\begin{array}{l}\mathrm{R}-20 \text { for } \\
48 \text { in. } \\
\text { (R-3.5 for } \\
1.22 \mathrm{~m})\end{array}$ & $\begin{array}{c}\text { R-25 for } 48 \\
\text { in. } \\
\text { (R-4.4 for } \\
1.22 \mathrm{~m} \text { ) }\end{array}$ \\
\hline \multirow{2}{*}{$\begin{array}{l}\text { Vertical } \\
\text { glazing } \\
\text { (including } \\
\text { doors) }\end{array}$} & $\begin{array}{l}\mathrm{U} \text {-value } \\
\mathrm{Btu} / \mathrm{h} \cdot \mathrm{ft}^{2} \cdot{ }^{\circ} \mathrm{F} \\
\left(\mathrm{W} / \mathrm{m}^{2} \cdot \mathrm{K}\right)\end{array}$ & $\begin{array}{c}\mathrm{U}-0.56 \\
(\mathrm{U}-3.18)\end{array}$ & $\begin{array}{c}\mathrm{U}-0.45 \\
(\mathrm{U}-2.56)\end{array}$ & $\begin{array}{c}\mathrm{U}-0.41 \\
(\mathrm{U}-2.33)\end{array}$ & $\begin{array}{c}\mathrm{U}-0.38 \\
(\mathrm{U}-2.16)\end{array}$ & $\begin{array}{c}\text { U-0.35 } \\
\text { (U-1.99) }\end{array}$ & $\begin{array}{c}\text { U-0.35 } \\
\text { (U-1.99) }\end{array}$ & $\begin{array}{c}\text { U-0.33 } \\
\text { (U-1.87) }\end{array}$ & $\begin{array}{c}\mathrm{U}-0.25 \\
(\mathrm{U}-1.42)\end{array}$ \\
\hline & SHGC & 0.28 & 0.24 & 0.24 & 0.24 & 0.23 & 0.38 & 0.38 & 0.37 \\
\hline
\end{tabular}

\subsubsection{Lighting Measures}

The lighting measures are not climate dependent. As such, the same recommendations are provided for all climate zones. Recommendations are provided for interior lighting, as well as exterior lighting, as shown in Table 7.2.

Interior lighting recommendations include maximum lighting power densities (LPD) requirements for the major space types in highway lodging buildings. Additional recommendations cover the minimum performance of the light sources and ballasts (minimum mean lumens/watt). Occupancy control recommendations are also provided.

Exterior lighting recommendations include maximum LPD requirements for exterior lighting applications in two lighting zones where highway lodging buildings are most likely located, as well as parking lot and façade lighting controls. 
Table 7.2. Final Energy Savings Recommendations - Lighting

\begin{tabular}{|c|c|c|c|c|}
\hline Item & \multicolumn{2}{|c|}{ Component } & \multicolumn{2}{|c|}{ Zones 1-8 } \\
\hline \multirow{8}{*}{$\begin{array}{l}\text { Interior } \\
\text { Lighting }\end{array}$} & \multirow{4}{*}{\multicolumn{2}{|c|}{$\begin{array}{l}\text { Lighting power density } \\
\mathrm{W} / \mathrm{ft}^{2}\left(\mathrm{~W} / \mathrm{m}^{2}\right)\end{array}$}} & Guest rooms $=0.71(7.64)$ & Office $=0.85(9.15)$ \\
\hline & & & Corridors $=0.50(5.38)$ & Lobbies $=0.77(8.29)$ \\
\hline & & & Exercise $=0.78(8.40)$ & Laundry $=0.60(6.46)$ \\
\hline & & & Meeting rooms $=1.14(12.3)$ & Stairs $=0.52(0.60)$ \\
\hline & \multicolumn{2}{|l|}{ Fluorescent lamps } & \multicolumn{2}{|c|}{$\begin{array}{l}\text { Compact fluorescent (CFL) with electronic ballast, } \\
\text { T5HO or T8 high-performance with high-performance } \\
\text { electronic ballast }\end{array}$} \\
\hline & \multicolumn{2}{|c|}{ Occupancy controls } & \multicolumn{2}{|c|}{$\begin{array}{l}\text { Bi-level in stairs, manual-on/auto-off for all laundry, } \\
\text { office, exercise, business center, employee break rooms, } \\
\text { meeting rooms, and non-public spaces }\end{array}$} \\
\hline & \multicolumn{2}{|c|}{ Guest room controls } & \multicolumn{2}{|c|}{$\begin{array}{l}\text { Occupancy-based control and entry and vacancy control } \\
\text { in bathroom }\end{array}$} \\
\hline & \multicolumn{2}{|l|}{ Plug load lighting } & \multicolumn{2}{|c|}{ Compact Fluorescent (CFL) with electronic ballast } \\
\hline \multirow{9}{*}{$\begin{array}{l}\text { Exterior } \\
\text { Lighting }\end{array}$} & \multicolumn{4}{|c|}{$\begin{array}{l}\text { Lighting Zone } 2=\text { Residential Mixed-use Areas and Neighborhood Business Districts } \\
\text { Lighting Zone } 3=\text { All other areas }\end{array}$} \\
\hline & \multirow{7}{*}{$\begin{array}{l}\text { Lighting power } \\
\text { density (LPD), } \\
\mathrm{W} / \mathrm{ft}^{2} \text { or } \mathrm{W} / \mathrm{lf} \\
\left(\mathrm{W} / \mathrm{m}^{2} \text { or } \mathrm{W} / \mathrm{m}\right)\end{array}$} & & Lighting Zone 2 & Lighting Zone 3 \\
\hline & & Base allowance & $600 \mathrm{~W}$ & $750 \mathrm{~W}$ \\
\hline & & Parking areas and drives & $0.06 \mathrm{~W} / \mathrm{ft}^{2}(0.65)$ & $0.10 \mathrm{~W} / \mathrm{ft}^{2}(1.08)$ \\
\hline & & $\begin{array}{l}\text { Walkways less than } \\
10 \text { feet wide }\end{array}$ & $0.70 \mathrm{~W} / \mathrm{lf}(2.30)$ & $0.80 \mathrm{~W} / \mathrm{lf}(2.63)$ \\
\hline & & $\begin{array}{l}\text { Walkways } 10 \text { feet wide } \\
\text { or greater }\end{array}$ & $0.14 \mathrm{~W} / \mathrm{ft}^{2}(1.51)$ & $0.16 \mathrm{~W} / \mathrm{ft}^{2}(1.72)$ \\
\hline & & Entry canopies & $0.25 \mathrm{~W} / \mathrm{ft}^{2}(2.69)$ & $0.40 \mathrm{~W} / \mathrm{ft}^{2}(4.30)$ \\
\hline & & $\begin{array}{l}\text { Facade (use wattage } \\
\text { only for facade) }\end{array}$ & $0.05 \mathrm{~W} / \mathrm{ft}^{2}(0.54)$ & $0.075 \mathrm{~W} / \mathrm{ft}^{2}(0.81)$ \\
\hline & Controls & $\begin{array}{l}\text { Parking lot and façade } \\
\text { lighting control }\end{array}$ & \multicolumn{2}{|c|}{$\begin{array}{l}\text { Bi-level control for parking lot lighting and time-of-day } \\
\text { operated control for facade lighting }\end{array}$} \\
\hline
\end{tabular}

\subsubsection{HVAC Measures}

HVAC measures include recommendations for minimum heating and cooling equipment efficiencies. Cooling equipment efficiencies are expressed as energy efficiency ratios (EER) and heating equipment efficiencies are expressed as thermal efficiencies $\left(E_{t}\right)$ or combustion efficiencies $\left(E_{c}\right)$ for furnaces and coefficients of performance (COP) for heat pumps. The recommended space heating and cooling system for highway lodging buildings is a water-source heat pump system. The design package also recommends advanced occupancy-based energy management system, lowering the capacity threshold for economizers to $54,000 \mathrm{Btu} / \mathrm{h}(15,830 \mathrm{~W})$ for zone 3 through 8 , using motorized dampers to control the introduction of 
outdoor air during off hours and energy recovery ventilator (ERV), and recommendations of low friction ductwork. As shown in Table 7.3 all the recommendations for HVAC are not climate dependent, except for the recommendations for economizers.

Table 7.3. Final Energy Savings Recommendations - HVAC

\begin{tabular}{|c|c|c|}
\hline Item & Component & Zones 1-8 (except economizer) \\
\hline \multirow{7}{*}{ HVAC } & $\begin{array}{l}\text { Water-source heat pumps, }<17 \mathrm{kBtu} / \mathrm{h} \\
(<4.98 \mathrm{~kW})\end{array}$ & 14.7 EER, 5.2 Htg COP. \\
\hline & $\begin{array}{l}\text { Water-source heat pumps, }>17 \mathrm{kBtu} / \mathrm{h} \text { and } \\
<65 \mathrm{kBtu}(>4.98 \mathrm{~kW} \text { and }<19.0 \mathrm{~kW})\end{array}$ & 17.6 EER, 5.9 Htg COP \\
\hline & $\begin{array}{l}\text { Water-source heat pumps, }>65 \mathrm{kBtu} \text { and } \\
<135 \mathrm{kBtu}(>19.0 \mathrm{~kW} \text { and }<39.6 \mathrm{~kW})\end{array}$ & 16.0 EER, 5.0 Htg COP \\
\hline & Water-source heat pump heat source & Use condensing boiler for circulating loop heat source \\
\hline & Pumping for water-source heat pumps & Variable speed pumping; water treatment \\
\hline & Water-source heat pump heat rejection & Control cooling tower to maximize heat pump EER \\
\hline & Water-source heat pump heat source & Condensing boiler with $95 \% \mathrm{E}_{\mathrm{t}}$ \\
\hline Controls & System operation and thermostat control & $\begin{array}{l}\text { Occupancy-based energy management system for } \\
\text { guest rooms, thermostat reset for meeting room, } \\
\text { employee lounge and exercise room }\end{array}$ \\
\hline Economizer & $\begin{array}{l}\text { Air conditioners and heat pumps } \\
\text { - single package }\end{array}$ & $\begin{array}{l}\text { Zone } 1 \text { and } 2 \text { : NR } \\
\text { Zone } 3 \text { to } 8 \text { : Cooling capacity }>54 \mathrm{kBtu} / \mathrm{h}\end{array}$ \\
\hline \multirow{2}{*}{ Ventilation } & Ventilation air supply & $\begin{array}{l}\text { Motorized damper to control ventilation supply } \\
\text { volume to match occupancy }\end{array}$ \\
\hline & Heat recovery & Ventilation heat recovery with toilet exhaust \\
\hline Ducts & Friction rate & 0.08 in. w.c. $/ 100$ feet \\
\hline
\end{tabular}

\subsubsection{Service Water Heating Measures}

SWH measures include recommendations for the use of high efficiency gas storage water heater, water-conserving equipment and drain water recovery. Table 7.4 summarizes the recommendations for the SWH measures.

Table 7.4. Final Energy Savings Recommendations - Service Water Heating

\begin{tabular}{lll}
\hline \multicolumn{1}{c}{ Item } & \multicolumn{1}{c}{ Component } & \multicolumn{1}{c}{ Zones 1-8 } \\
\hline \multirow{2}{*}{$\begin{array}{l}\text { Service } \\
\text { Water }\end{array}$} & Gas storage water heater efficiency & $95 \% \mathrm{E}_{\mathrm{t}}$ \\
Heating & Hot water usage reduction & $\begin{array}{l}\text { Use } 1.75 \mathrm{gpm} \text { shower heads, } 1.0 \text { gpm faucets and } 0.45 \text { gal } \\
\text { hot water/lb laundry water-conserving clothes washers. }\end{array}$ \\
& & Utilize laundry and shower heat recovery. \\
\hline
\end{tabular}




\subsubsection{Miscellaneous Appliances Measures}

Recommendations for plug loads are provided as shown in Table 7.5. Plug load recommendations include using an absorption type of refrigerator in guest rooms, a high-efficiency washer, reduced connected wattage, and control equipment to further reduce average energy usage. The connected wattage recommendations include selection of Energy Star products for computers, monitors and other equipment. The controls strategies include occupancy-based control to turn off receptacles in guest rooms when unoccupied, power management software for networked computers, vending machine occupancy sensor controls and timer switches for equipment that do not need to be on during off-hours, such as coffee makers and water coolers.

Table 7.5. Final Energy Savings Recommendations - Miscellaneous Appliances

\begin{tabular}{ll}
\hline Component & \multicolumn{1}{c}{ Zones 1-8 } \\
\hline Guest room mini-refrigerator & Absorption refrigeration cycle 33W continuously \\
High efficiency laundry equipment & $\begin{array}{l}0.45 \text { gal hot water/lb laundry 354 G extractor with } \\
\text { retained water }<52.5 \%\end{array}$ \\
High efficiency equipment & $\begin{array}{l}\text { ENERGY STAR products for TVs, computers- servers, } \\
\text { desktop, monitors, laser printers, copy machines, fax } \\
\text { machines, water coolers, refrigerators }\end{array}$ \\
Controls & $\begin{array}{l}\text { Occupancy-based control to turn off guest room } \\
\text { receptacles during unoccupied period; } \\
\text { Power management software for office equipment, timer } \\
\text { switches to turn off water coolers and coffee makers in } \\
\text { off-hours }\end{array}$ \\
\hline
\end{tabular}

\subsection{Energy Savings Results}

This section presents the results of EnergyPlus simulation performed to determine the level of energy savings achieved by the advanced model based on EEMs summarized in Section 7.1. Energy savings are calculated for 16 climate locations covering all 8 climate zones. Figure 7.1 shows the percentage of onsite energy savings of the advanced models in comparison with the ASHRAE Standard 90.1-2004 baseline. The energy simulation results show that the 50\% energy savings goal is achieved in all climate zones and provide a national weighted-average savings of $55.5 \%$ using the construction weighting factors presented in Section 2.3. 


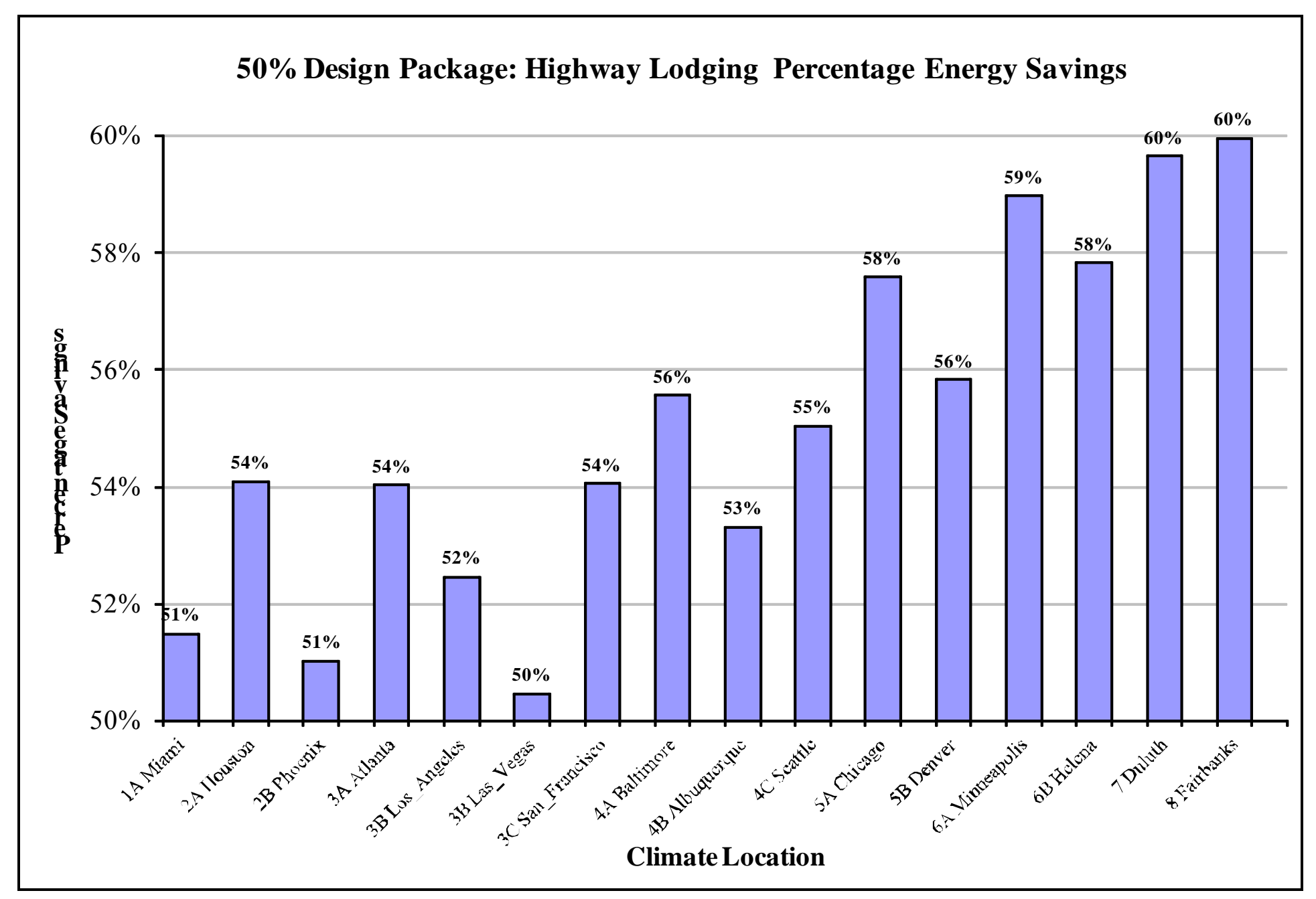

Figure 7.1. Percentage of the Site Energy Savings 
The estimated savings vary between 50 and $60 \%$ depending on the climate zone. To understand the impact of EEMs on different energy end use sectors, the energy end use intensities for the baseline and the advanced model is illustrated in Figure 7.2. The annual energy usage by usage category is also shown in Table 7.6.

- The lighting related measures reduce about $40 \%$ of interior lighting energy and $55 \%$ of exterior lighting energy. The above percentages are observed to be nearly the same across all 16 climate locations. The interior lighting energy savings are achieved with a combination of reduced lighting power density and occupancy control requirements. The exterior lighting energy savings are realized with the use of bi-level controls for parking lot lighting, time-of-day control for facade lighting, and a general reduction in exterior lighting power density based on ASHRAE Standard 90.1-2010 requirements.

- The equipment and plug load energy savings average about $30 \%$ in all climate zones. There are several efficiency measures recommended in this report, including the use of absorption type refrigerators in guest rooms, and high efficiency washers that reduce the clothes dryer energy use. Other plug load reductions are realized from the use of occupancy sensors and power energy management systems to control the plug loads during unoccupied hours.

- The space cooling energy is reduced by a national weighted-average of $63 \%$ because of the high efficiency water source heat pumps and the advanced HVAC system controls, the improved envelope insulation levels, high performance windows, reduced interior lighting energy use, and reduced plug loads. In addition, all common area systems require economizers in most climate zones, along with an energy recovery ventilation system and motorized damper control for outdoor air intake. Cooling energy savings vary by climate zone with the highest savings of $70 \%$ in climate zone $2 \mathrm{~A}$ and lowest savings of $44 \%$ in climate zone $6 \mathrm{~B}$.

- The space heating energy is reduced by about weighted-average of $88 \%$ as a result of the improved envelope insulation levels, high performance windows, the high efficiency watersource heat pump system and the advanced HVAC system controls. The space heating is reduced by more than $95 \%$ in several locations in climate zones $1-4$, and the lowest energy savings is about $72 \%$ in climate zone 8 .

- The service water heating energy use is reduced by an average of $86 \%$ with all climate zones contributing to $20 \sim 30 \%$ of total energy savings. The service hot water energy savings is realized with high efficiency water heater, high efficiency laundry equipment, water usage-reduction with low-flow shower heads and plumbing fixtures, and drain water heat recovery system. 


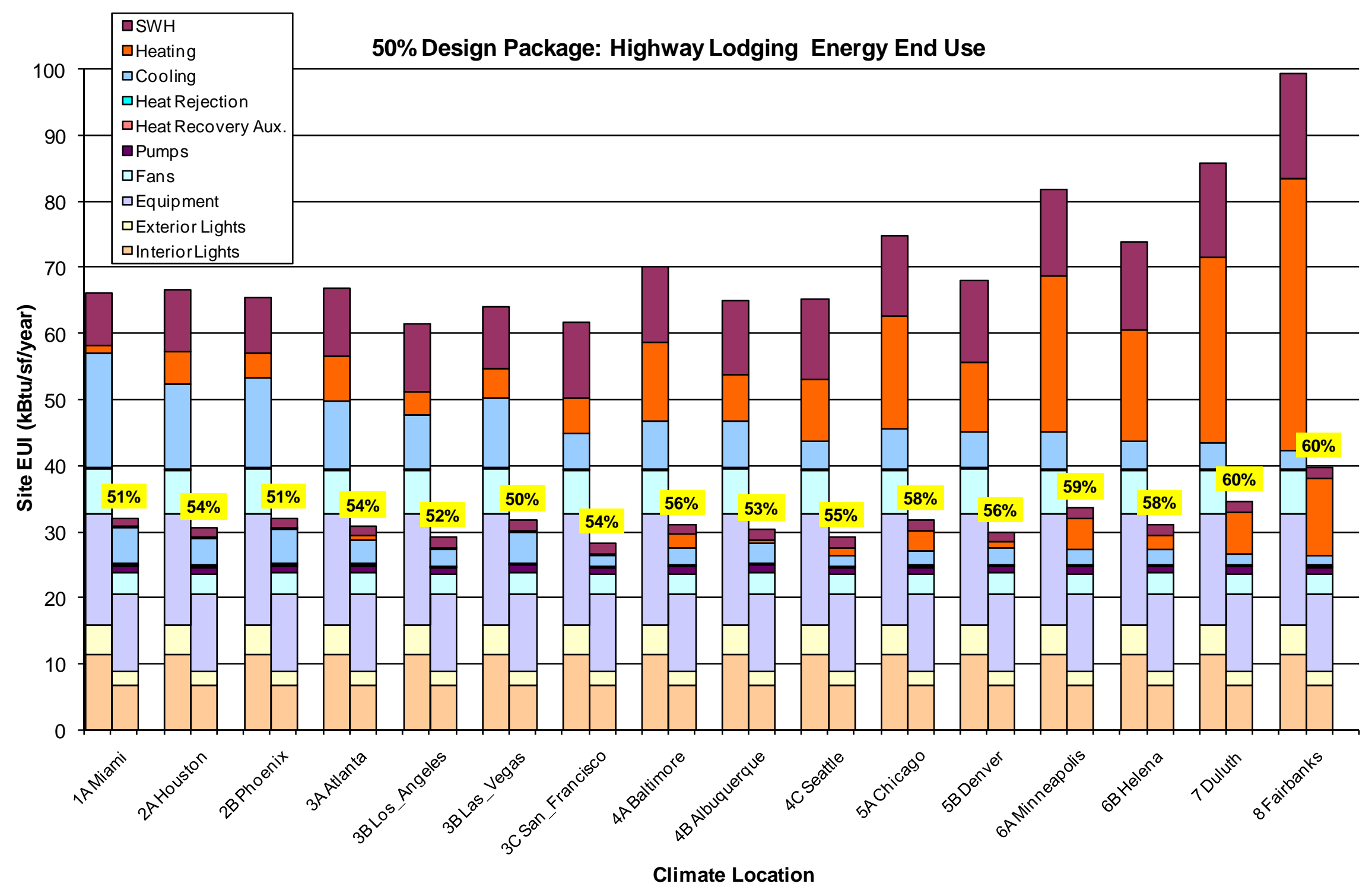

Figure 7.2. Site Energy Savings by End Use Category Relative to 90.1-2004 Baseline 
Table 7.6. Energy Savings Results by End Use

\begin{tabular}{|c|c|c|c|c|c|c|c|c|c|c|c|c|c|c|c|}
\hline & Zone & $\begin{array}{l}\text { Heating } \\
\text { [MMBtu] }\end{array}$ & $\begin{array}{c}\text { Cooling } \\
\text { [MMBtu] }\end{array}$ & $\begin{array}{c}\text { Interior } \\
\text { Lights } \\
\text { [MMBtu] }\end{array}$ & $\begin{array}{c}\text { Exterior } \\
\text { Lights } \\
\text { [MMBtu] }\end{array}$ & $\begin{array}{c}\text { Interior } \\
\text { Equipment } \\
\text { [MMBtu] }\end{array}$ & $\begin{array}{c}\text { Fans } \\
\text { [MMBtu] }\end{array}$ & $\begin{array}{c}\text { Pumps } \\
\text { [MMBtu] }\end{array}$ & $\begin{array}{c}\text { Heat } \\
\text { Rejection } \\
\text { [MMBtu] }\end{array}$ & $\begin{array}{c}\text { Humidific } \\
\text { ation } \\
\text { [MMBtu] }\end{array}$ & $\begin{array}{c}\text { Heat } \\
\text { Recovery } \\
\text { [MMBtu] }\end{array}$ & $\begin{array}{c}\text { Water } \\
\text { Heater } \\
\text { [MMBtu] }\end{array}$ & $\begin{array}{c}\text { Total } \\
\text { Energy } \\
{[\text { MMBtu] }}\end{array}$ & $\begin{array}{c}E U I \\
{[k B t u / S F]}\end{array}$ & $\begin{array}{c}\text { Energy } \\
\text { Savings } \\
\text { (\%) }\end{array}$ \\
\hline DOE50pct_HotelSmall_STD2004_Miami & \multirow[b]{2}{*}{$1 \mathrm{~A}$} & 54 & 745 & 491 & 194 & 720 & 303 & 1 & 0 & 0 & 0 & 340 & 2,849 & 66.3 & \multirow{2}{*}{$51 \%$} \\
\hline DOE50pct HotelSmall AEDG50 Miami & & 0 & 242 & 291 & 87 & 502 & 144 & 46 & 13 & 0 & 6 & 50 & 1,382 & 32.1 & \\
\hline DOE50pct_HotelSmall_STD2004_Houston & \multirow{2}{*}{$2 \mathrm{~A}$} & 214 & 551 & 491 & 194 & 720 & 298 & 1 & 0 & 0 & 0 & 396 & 2,865 & 66.6 & \multirow{2}{*}{$54 \%$} \\
\hline DOE50pct_HotelSmall_AEDG50_Houston & & 16 & 167 & 291 & 87 & 502 & 135 & 46 & 9 & 0 & 5 & 56 & 1,315 & 30.6 & \\
\hline DOE50pct_HotelSmall_STD2004_Phoenix & \multirow{2}{*}{$2 \mathrm{~B}$} & 162 & 582 & 491 & 194 & 720 & 307 & 1 & 0 & 0 & 0 & 363 & 2,820 & 65.6 & \multirow{2}{*}{$51 \%$} \\
\hline DOE50pct_HotelSmall_AEDG50_Phoenix & & 3 & 233 & 291 & 87 & 502 & 143 & 46 & 8 & 0 & 5 & 62 & 1,381 & 32.1 & \\
\hline DOE50pct_HotelSmall_AEDG50_Atlanta & $3 \mathrm{~A}$ & 31 & 151 & 291 & 87 & 502 & 142 & 46 & 7 & 0 & 6 & 61 & 1,324 & 30.8 & $54 \%$ \\
\hline DOE50pct_HotelSmall_STD2004_Los_Angeles & \multirow{2}{*}{ 3B } & 152 & 354 & 491 & 194 & 720 & 292 & 1 & 0 & 0 & 0 & 440 & 2,645 & 61.5 & \multirow{2}{*}{$52 \%$} \\
\hline DOE50pct_HotelSmall_AEDG50_Los_Angeles & & 1 & 120 & 291 & 87 & 502 & 139 & 46 & 4 & 0 & 1 & 66 & 1,257 & 29.2 & \\
\hline DOE50pct_HotelSmall_STD2004_Las_Vegas & \multirow{2}{*}{ 3B } & 191 & 455 & 491 & 194 & 720 & 301 & 1 & 0 & 0 & 0 & 403 & 2,757 & 64.1 & \multirow{2}{*}{$50 \%$} \\
\hline DOE50pct_HotelSmall_AEDG50_Las_Vegas & & 4 & 209 & 291 & 87 & 502 & 150 & 46 & 6 & 0 & 5 & 65 & 1,365 & 31.8 & \\
\hline DOE50pct_HotelSmall_STD2004_San_Francisco & \multirow{2}{*}{$3 \mathrm{C}$} & 228 & 234 & 491 & 194 & 720 & 295 & 1 & 0 & 0 & 0 & 487 & 2,651 & 61.6 & \multirow{2}{*}{$54 \%$} \\
\hline DOE50pct_HotelSmall_AEDG50_San_Francisco & & 6 & 76 & 291 & 87 & 502 & 136 & 46 & 2 & 0 & 3 & 68 & 1,218 & 28.3 & \\
\hline DOE50pct_HotelSmall_STD2004_Baltimore & \multirow{2}{*}{$4 \mathrm{~A}$} & 505 & 315 & 491 & 194 & 720 & 294 & 1 & 0 & 0 & 0 & 493 & 3,013 & 70.1 & \multirow{2}{*}{$56 \%$} \\
\hline DOE50pct_HotelSmall_AEDG50_Baltimore & & 86 & 112 & 291 & 87 & 502 & 139 & 46 & 4 & 0 & 6 & 65 & 1,339 & 31.1 & \\
\hline DOE50pct_HotelSmall_STD2004_Seattle & \multirow{2}{*}{$4 \mathrm{C}$} & 407 & 181 & 491 & 194 & 720 & 293 & 1 & 0 & 0 & 0 & 516 & 2,802 & 65.2 & \multirow{2}{*}{$55 \%$} \\
\hline DOE50pct_HotelSmall_AEDG50_Seattle & & 54 & 67 & 291 & 87 & 502 & 137 & 46 & 2 & 0 & 5 & 69 & 1,260 & 29.3 & \\
\hline DOE50pct_HotelSmall_STD2004_Chicago & \multirow{2}{*}{$5 \mathrm{~A}$} & 734 & 258 & 491 & 194 & 720 & 294 & 1 & 0 & 0 & 0 & 530 & 3,223 & 75.0 & \multirow[b]{2}{*}{$58 \%$} \\
\hline DOE50pct_HotelSmall_AEDG50_Chicago & & 130 & 96 & 291 & 87 & 502 & 137 & 46 & 3 & 0 & 6 & 69 & 1,367 & 31.8 & \\
\hline DOE50pct_HotelSmall_STD2004_Denver & \multirow{2}{*}{$5 \mathrm{~B}$} & 455 & 229 & 491 & 194 & 720 & 304 & 1 & 0 & 0 & 0 & 529 & 2,925 & 68.0 & \multirow{2}{*}{$56 \%$} \\
\hline DOE50pct_HotelSmall_AEDG50_Denver & & 32 & 109 & 291 & 87 & 502 & 145 & 46 & 3 & 0 & 6 & 70 & 1,292 & 30.0 & \\
\hline DOE50pct_HotelSmall_STD2004_Minneapolis & \multirow{2}{*}{$6 \mathrm{~A}$} & 1015 & 242 & 491 & 194 & 720 & 293 & 1 & 0 & 0 & 0 & 564 & 3,520 & 81.8 & $59 \%$ \\
\hline DOE50pct_HotelSmall_AEDG50_Minneapolis & & 199 & 100 & 291 & 87 & 502 & 140 & 46 & 3 & 0 & 6 & 70 & 1,444 & 33.6 & $59 \%$ \\
\hline DOE50pct_HotelSmall_STD2004_Helena & $6 \mathrm{~B}$ & 725 & 179 & 491 & 194 & 720 & 298 & 1 & 0 & 0 & 0 & 568 & 3,177 & 73.9 & $58 \%$ \\
\hline DOE50pct_HotelSmall_AEDG50_Helena & & 88 & 101 & 291 & 87 & 502 & 144 & 46 & 2 & 0 & 7 & 71 & 1,340 & 31.2 & $50 \%$ \\
\hline DOE50pct_HotelSmall_STD2004_Duluth & 7 & 1204 & 168 & 491 & 194 & 720 & 298 & 1 & 0 & 0 & 0 & 616 & 3,693 & 85.9 & $60 \%$ \\
\hline DOE50pct_HotelSmall_AEDG50_Duluth & 1 & 271 & 71 & 291 & 87 & 502 & 140 & 46 & 2 & 0 & 7 & 73 & 1,490 & 34.7 & $00 \%$ \\
\hline DOE50pct_HotelSmall_STD2004_Fairbanks & 8 & 1769 & 122 & 491 & 193 & 720 & 294 & 1 & 0 & 0 & 0 & 681 & 4,271 & 99.3 & $60 \%$ \\
\hline DOE50pct_HotelSmall_AEDG50_Fairbanks & 8 & 500 & 63 & 291 & 88 & 502 & 137 & 46 & 2 & 0 & 7 & 76 & 1,710 & 39.8 & $00 \%$ \\
\hline
\end{tabular}




\subsection{Suggestions for Future Work}

In this section, we offer suggestions to improve future 50\% (or beyond) design package analysis. We group our recommendations into three main categories: analysis approach; adjustments to the building prototype and energy modeling; and additional energy efficiency measures.

\subsection{Analysis Approach}

The analysis approach and methodology adopted for this work more or less follow what were used for the previous $A E D G$ work. Some suggestions for improving the approach are as follows:

- The work focuses on site energy savings for a package of measures to achieve an overall percentage savings target. With emphasis on reducing carbon emissions, it is useful to consider source energy in addition to site energy reduction.

- The simple payback period method is adopted as the metric for cost-effectiveness study in this work. To assess the additional costs, savings and benefits of various EEMs over their life time, however, the authors suggest that the life cycle cost analysis method would be more appropriate.

- The analysis approach in this work decouples the energy savings evaluation from the cost effectiveness analysis. The latter follows after the former is complete. It would be superior, and more reflective of real world realities, to use an integrated approach to identify costeffective recommendations for different climate locations, and to consider energy and cost saving potential simultaneously. This is particularly important because we see relatively long pay back periods for the set of EEMs recommended in this design package.

- Except for the building envelope measures and economizer, the same set of EEMs is recommended for all climate locations. We recommend exploring a spectrum of options for HVAC, SWH, and others to have customized paths for different climates to reach the $50 \%$ savings goal with consideration of location-dependent energy saving potential and economic data.

\subsection{Adjustments to Prototypes and Energy Modeling}

Some adjustments to the highway lodging prototype would refine the starting point and facilitate evaluating some energy measures. In addition, the current energy models in EnergyPlus could be improved to simulate the energy use more accurately.

- The current prototype focuses on only one assembly type for each of the envelope components. Like the AEDG-HL, we suggest evaluating more construction types that are applicable to highway lodging buildings.

- We recommend refining development of windows inputs to better match code and high performance windows, possibly with framing defined separately.

- Refine the modeling approach for the make-up air system. Make-up air system is modeled approximately in the advanced models as a result of the limitation of EnergyPlus not being able to model two systems serving one zone. 
- Improve the sizing methodology in EnergyPlus for WSHP system in the advanced models. In EnergyPlus, WSHP equipment size-related parameters for the cooling and heating coil models, such as the rated water flow rate, only allow user-defined values and no program autosizing is provided. Consequently, the cooling tower and boiler loop cannot be autosized for different climate locations. In the current energy models, WSHP loop size is fixed regardless of the climate, and the system may be oversized for some of the climate locations.

\subsection{Advanced Building - Additional Potential Energy Measures}

During the course of the analysis and from the valuable peer review and internal comments, we identified additional energy measures or refinements of energy measures for consideration in future work. These may make possible $50 \%$ or higher savings while being more cost-effective, or facilitate even higher savings percentages.

- For public spaces, consider exterior shading with automatic controls or electrothermic glazes, particularly for climates with both hot summers and cold winters.

- Consider daylighting for ground floor public spaces and top floor corridor.

- Consider measures to reduce envelope infiltration. Continuous air barriers are worth consideration.

- Use more aggressive EEMs for guest room plug loads.

- Use wider thermostat setback and setup for vacant guest rooms.

- Use occupancy-based exhaust control for rented guest rooms during unoccupied period

- Consider alternative HVAC systems: ground-source heat pump system, variable refrigerant flow system, heat pump fan-coil system with localized ERV, direct/indirect evaporative cooling in dry climates.

- Consider ozone laundry system

- Consider onsite generation of thermal and electrical energy onsite including co-generation, fuel cells, solar thermal (water, air) and renewable electricity generation. 


\subsection{References}

AHLA. 2008. 2008 Lodging Industry Profile. American Hotel \& Lodging Association, Washington, D.C. Last Accessed on August 15, 2009 at http://www.ahla.com/uploadedFiles/AHLA/information_center/08LIP_web.pdf

ANSI/ASHRAE. 1999. ASHRAE Standard 62-1999, Ventilation for Acceptable Indoor Air Quality, American Society of Heating, Refrigerating and Air-Conditioning Engineers, Atlanta, Georgia.

ANSI/ASHRAE. 2004. ASHRAE Standard 62.1-2004, Ventilation for Acceptable Indoor Air Quality, American Society of Heating, Refrigerating and Air-Conditioning Engineers, Atlanta, Georgia.

ANSI/ASHRAE/IESNA. 1999. ANSI/ASHRAE/IESNA Standard 90.1-1999, Energy Standard for Buildings Except Low-Rise Residential Buildings. American Society of Heating, Refrigerating and AirConditioning Engineers, Atlanta, Georgia.

ANSI/ASHRAE/IESNA. 2004a. ANSI/ASHRAE/IESNA Standard 90.1-2004, Energy Standard for Buildings Except Low-Rise Residential Buildings. American Society of Heating, Refrigerating and AirConditioning Engineers, Atlanta, Georgia.

ANSI/ASHRAE/IESNA. 2004b. User's Manual for ANSI/ASHRAE/IESNA Standard 90.1-2004, Energy Standard for Buildings Except Low-Rise Residential Buildings. American Society of Heating, Refrigerating and Air-Conditioning Engineers, Atlanta, Georgia.

ANSI/ASHRAE/IESNA. 2007. ANSI/ASHRAE/IESNA Standard 90.1-2007, Energy Standard for Buildings Except Low-Rise Residential Buildings. American Society of Heating, Refrigerating and AirConditioning Engineers, Atlanta, Georgia.

ASHRAE. 2005. Handbook of Fundamentals, American Society of Heating, Refrigerating and AirConditioning Engineers, Inc., Atlanta, Georgia, 2005.

ASHRAE. 2007. HVAC Applications Handbook, American Society of Heating, Refrigerating and AirConditioning Engineers, Inc., Atlanta, Georgia.

ASHRAE/IESNA. 1989. ASHRAE/IESNA Standard 90.1-1989, Energy Efficient Design of New Building Except Low-Rise Residential Buildings. American Society of Heating, Ventilating and Air-Conditioning Engineers, Inc., Atlanta, Georgia.

ASHRAE. 2004. Advanced Energy Design Guide for Small Office Buildings. American Society of Heating, Ventilating and Air-Conditioning Engineers, Inc., Atlanta, Georgia.

ASHRAE, 2006. Advanced Energy Design Guide for Small Retail Buildings. American Society of Heating, Ventilating and Air-Conditioning Engineers, Inc., Atlanta, Georgia.

ASHRAE. 2008. Advanced Energy Design Guide for Small Warehouses and Self-Storage Buildings. American Society of Heating, Ventilating and Air-Conditioning Engineers, Inc., Atlanta, Georgia. 
ASHRAE. 2009. Advanced Energy Design Guide for Highway Lodging Buildings. American Society of Heating, Ventilating and Air-Conditioning Engineers, Inc., Atlanta, Georgia.

Briggs R.L., R.G. Lucas, and Z.T. Taylor. 2003. Climate Classification for Building Energy Codes and Standards: Part 1-Development Process. ASHRAE Transactions 2003 (1) Page 4610. American Society of Heating, Refrigerating and Air-Conditioning Engineers, Inc., Atlanta, Georgia, 2003.

California Energy Commission Appliances Database, California Energy Commission. Sacramento, California. Last accessed on March 15, 2009 at http://www.energy.ca.gov/appliances/database/

CEC. 2005. Case Study - Hotel Bathroom Lighting Control System. Pub \# CEC-500-2005-141-A26, California Energy Commission.

Continental. 2007. E-Series High Performance Water Extractor Specifications. Continental Girbau Inc., Last accessed September 10, 2009, http://worldwidelaundry.com/brochures/continental/CoinE_SeriesBrochure.pdf

DOE. 2000. Screening Analysis for EPACT-Covered Commercial HVAC and Water-Heating Equipment. U.S. Department of Energy, Washington, D.C.

DOE. 2005. Heat Recovery from Wastewater Using a Gravity-Film Heat Exchanger, DOE/EE-0247 Revised, Washington, D.C.

DOE. 2009. Commercial Building Benchmark Models. Last accessed on September 16, 2009 at http://www1.eere.energy.gov/buildings/commercial_initiative/benchmark_models.html

Ducker Worldwide. 2001. 2000 U.S. Market for Residential and Specialty Air Conditioning: PTAC (Packaged Terminal Air Conditioning). HVAC0002. Final Report, March 2001. Ducker Industrial Standards, 6905 Telegraph Road Suite 300, Bloomfield Hills, MI 48301.

CBECS. 2003. Commercial Buildings Energy Consumption Survey 2003, Energy Information Administration of U.S. Department of Energy, Washington, D.C. Last accessed on December 26, 2008 at http://www.eia.doe.gov/emeu/cbecs/contents.html

Cool Roofing. 2004. Cool Roof Materials Database maintained by the Lawrence Berkeley National Laboratory. Berkeley, California. Last accessed on March 26, 2009 at http://eetd.lbl.gov/coolroof

EIA. 2006. Annual Energy Review 2006. Last accessed in July, 2009 at http://www.eia.doe.gov/emeu/aer/pdf/aer.pdf

Eilert, P. 2000. High Albedo (Cool) Roofs - Codes and Standards Enhancement (CASE) Study. Pacific Gas and Electric Company, San Francisco, California. Last accessed on December 30, 2008 at www.pge.com/includes/docs/pdfs/shared/saveenergymoney/rebates/remodeling/coolroof/coolroofdesignb rief.pdf

Emmerich, S.J., et al. 2005. Investigation of the Impact of Commercial Building Envelope Airtightness on HVAC Energy Use, June, 2005. National Institute of Standards and Technology, Report No. NISTIR 7238. Gaithersburg, Maryland. 
Energy Design Resources. 2002. Design Brief: Options and Opportunities. Last accessed on December 26, 2008 at http://www.energydesignresources.com/Resources

Galasiu AD, GR Newsham, C Savagau, and DM Sander. 2007. "Energy Saving Lighting Control Systems for Open Plan Offices: A Field Study.” Leukos 4 (1), pp. 7-29.

Jarnagin RE, B Liu, DW Winiarski, MF McBride, L Suharli, and D Walden. 2006. Technical Support Document: Development of the Advanced Energy Design Guide for Small Office Buildings.

PNNL-16250, Pacific Northwest National Laboratory, Richland, Washington.

Jiang W, RE Jarnagin, K Gowri, MF McBride, and L Bing. 2008. Technical Support Document: Development of the Advanced Energy Design Guide for Highway Lodging Buildings. PNNL-17875, Pacific Northwest National Laboratory, Richland, Washington.

Konopacki S and H Akbari. 2001. Measured Energy Savings and Demand Reduction form a Reflective Roof Membrane on a Large Retail Store in Austin. Technical Report LBNL-47149, Lawrence Berkeley National Laboratory, Berkeley, California.

LBNL. 2009. Cool Roofing Materials Database. Lawrence Berkley Laboratory, California. Last accessed in March 2009 at http://eetd.lbl.gov/coolroofs/

Liu, B., R.E. Jarnagin, D.W. Winiarski, W. Jiang, M.F. McBride and and G.C. Crall. 2006. Technical Support Document: Development of the Advanced Energy Design Guide for Small Retail Buildings. September, 2006. Pacific Northwest National Laboratory, PNNL-16031. Richland, Washington.

Liu, B., Jarnagin R.E., Jiang, W., and Gowri K. 2007. Technical Support Document: Development of the Advanced Energy Design Guide for Small Warehouse and Self-storage Buildings. December, 2007. Pacific Northwest National Laboratory, Richland, Washington.

LRC. 2004. Reducing Barriers to Use of High Efficiency Lighting. Final Report Year 3. Lighting Research Center, Rensselare Polytechnic Institute.

New Building Institute. 2005. Energy Benchmark for High Performance Buildings, version 1.1. Last accessed on December 26, 2008 http://www.advancedbuildings.net/publications.htm

New Building Institute. 2008. Buildings Database. Last accessed on December 26, 2008 http://www.gettingtofifty.org/buildings.htm

Pless, S., P. Torcellini and N. Long (2007). Technical Support Document: Development of the Advanced Energy Design Guide for K-12 Schools--30\% Energy Savings. National Renewable Energy Laboratory. NREL/TP-550-42114. Golden, CO.

PNNL. 2004. Technical Support Document: Energy Efficiency Program for Commercial and Industrial Equipment: Advanced Notice of Proposed Rulemaking for Commercial Unitary Air Conditioners and Heat Pumps, July, 2004. U.S. Department of Energy (http://www.eere.energy.gov/buildings/appliance_standards/commercial/pdfs/cuac tsd chp_6.pdf)

Rivas J. 2009. Managing Plug Loads, E-Source, presented on February 19, 2009. 
Richman, E.E., E. Rauch, J. Knappek, J. Phillips, K. Petty and P. Lopez-Rangel. 2008. National Commercial Construction Characteristics and Compliance with Building Energy Codes: 1999-2007. 2008 ACEEE Summery Study on Energy Efficiency in Buildings, Pacific Grove, California, August 17$22,2008$.

Roberson JA, GK Homan, A Mahajan, B Nordman, C Webber, RE Brown, M McWhinney, and JG Koomey. 2002. Energy Use and Power Levels in New Monitors and Personal Computers. LBNL-48581. July 2002. Lawrence Berkeley National Laboratory, Berkeley, California.

Sachs, H. M. 2005. Opportunities for Elevator Energy Efficiency Improvements. American Council for an Energy-Efficient Economy. Washington, D.C.

Sanchez M, C Webber, R Brown, J Busch, M Pinckard and J Roberson. 2007. Space Heaters, Computers, Cell Phone Chargers: How. Plugged In Are Commercial Buildings? LBNL-62397, Lawrence Berkeley National Laboratory, California.

Swami, H.V. and S. Chandra. 1987. Procedures for Calculating Natural Ventilation Airflow Rates in Buildings. Final Report FSEC-CR-163-86. Florida Solar Energy Center, Cape Canaveral.

Tang CC. 2005. Modeling Packaged Heat Pumps in Quasi-Steady State Energy Simulation Program. M.S. Thesis. Department of Mechanical and Aerospace Engineering, Oklahoma State University.

Torcellini P, M Deru, B Griffith, K Benne, M Halverson, D Winiarski, and D Crawley. DOE Commercial Building Benchmark Models. The 2008 ACEEE Summer Study on Energy Efficiency in Buildings Pacific Grove, California, August 17-22, 2008.

U.S. Green Building Council. 2009. LEED 2009 Rating Systems. USGBC, Washington, D.C.

VonNeida B, D Maniccia, and T Allan. 2000. An Analysis of the Energy and Cost Savings Potential of Occupancy Sensors for Commercial Lighting Systems. www.lrc.rpi.edu/resources/pdf/. Last accessed in February 2009

Wassmer M and MJ Brandemuehl. 2006. Effect of Data Availability on Modeling of Residential Air Conditioners and Heat Pumps for Energy Calculations. ASHRAE Transactions 111(1), pp. 214-225.

Zaloum C, M Lafrance, and J Gusdorf. 2007. Drain Water Heat Recovery Characterization and Modeling Final Draft, Sustainable Buildings and Communities, Natural Resources Canada. 


\section{Appendix A}

\section{Building Energy Modeling Schedules}


Table A.1. Occupancy Schedules

\begin{tabular}{|c|c|c|c|c|c|c|c|c|c|c|c|c|c|c|c|c|c|c|c|c|c|c|c|c|c|}
\hline \multirow{2}{*}{ Space Type } & \multirow{2}{*}{ Day Type } & 1 & 2 & 3 & 4 & 5 & 6 & 7 & 8 & 9 & 10 & 11 & 12 & 13 & 14 & 15 & 16 & 17 & 18 & 19 & 20 & 21 & 22 & 23 & 24 \\
\hline & & $12-1 \mathrm{a}$ & $1-2 \mathrm{a}$ & $2-3 a$ & $3-4 a$ & $4-5 a$ & $5-6 a$ & $6-7 a$ & $7-8 \mathrm{a}$ & $8-9 a$ & $9-10 \mathrm{a}$ & $10-11 \mathrm{a}$ & $11-12 p$ & $12-1 p$ & $1-2 p$ & $2-3 p$ & $3-4 p$ & $4-5 p$ & $5-6 \mathrm{p}$ & $6-7 p$ & $7-8 p$ & $8-9 p$ & $9-10 \mathrm{p} 1$ & $10-11 \mathrm{p} 1$ & $11-12$ \\
\hline \multirow{2}{*}{ Guest Room } & Weekday & 1.00 & 1.00 & 1.00 & 1.00 & 1.00 & 1.00 & 0.77 & 0.43 & 0.43 & 0.20 & 0.20 & 0.20 & 0.20 & 0.20 & 0.20 & 0.31 & 0.54 & 0.54 & 0.54 & 0.77 & .77 & 0.89 & 1.00 & 1.00 \\
\hline & Sat./Sun./Hol. & 1.00 & 1.00 & 1.00 & 1.00 & 1.00 & 1.00 & 0.77 & 0.53 & 0.53 & 0.30 & 0.30 & 0.30 & 0.30 & 0.30 & 0.30 & 0.30 & 0.30 & 0.53 & 0.65 & 0.65 & 0.65 & 0.77 & 0.77 & 0.77 \\
\hline \multirow{2}{*}{ Lobby } & Weekday & 0.10 & 0.10 & 0.10 & 0.10 & 0.10 & 0.30 & 0.70 & 0.70 & 0.70 & 0.70 & 0.20 & 0.20 & 0.20 & 0.20 & 0.20 & 0.20 & 0.40 & 0.40 & 0.20 & 0.20 & 0.20 & 0.20 & 0.10 & 0.10 \\
\hline & Sat./Sun./Hol. & 0.10 & 0.10 & 0.10 & 0.10 & 0.10 & 0.10 & 0.30 & 0.70 & 0.70 & 0.70 & 0.20 & 0.20 & 0.20 & 0.20 & 0.20 & 0.20 & 0.40 & 0.40 & 0.20 & 0.20 & 0.20 & 0.20 & 0.10 & 0.10 \\
\hline \multirow{2}{*}{ Office } & Weekday & 0.20 & 0.20 & 0.20 & 0.20 & 0.20 & 0.20 & 0.30 & 0.40 & 1.00 & 1.00 & 1.00 & 1.00 & 0.50 & 1.00 & 1.00 & 1.00 & 1.00 & 0.40 & 0.30 & 0.20 & 0.20 & 0.20 & 0.20 & 0.20 \\
\hline & Sat./Sun & 0.20 & 0.20 & 0.20 & 0.20 & 0.20 & 0.20 & 0.20 & 0.30 & 0.50 & 0.50 & 0.50 & 0.50 & 0.50 & 0.50 & 0.50 & 0.50 & 0.50 & 0.30 & 0.20 & 0.20 & 0.20 & 0.20 & 0.20 & 0.20 \\
\hline \multirow{2}{*}{ Employee Lounge } & Weekday & 0.00 & 0.00 & 0.00 & 0.00 & 0.00 & 0.10 & 0.10 & 0.20 & 0.20 & 0.20 & 0.20 & 0.20 & 0.70 & 0.20 & 0.20 & 0.20 & 0.20 & 0.20 & 0.10 & 0.10 & 0.00 & 0.00 & 0.00 & 0.00 \\
\hline & Sat./Sun./Hol. & 0.00 & 0.00 & 0.00 & 0.00 & 0.00 & 0.05 & 0.05 & 0.05 & 0.10 & 0.10 & 0.10 & 0.10 & 0.20 & 0.10 & 0.10 & 0.10 & 0.10 & 0.10 & 0.05 & 0.05 & 0.00 & 0.00 & 0.00 & 0.00 \\
\hline \multirow{2}{*}{ Meeting Room } & Weekday & 0.00 & 0.00 & 0.00 & 0.00 & 0.00 & 0.00 & 0.00 & 0.05 & 0.50 & 0.50 & 0.20 & 0.20 & 0.05 & 0.50 & 0.50 & 0.20 & 0.20 & 0.20 & 0.05 & 0.05 & 0.00 & 0.00 & 0.00 & 0.00 \\
\hline & Sat./Sun./Hol. & 0.00 & 0.00 & 0.00 & 0.00 & 0.00 & 0.00 & 0.00 & 0.05 & 0.50 & 0.50 & 0.20 & 0.20 & 0.05 & 0.50 & 0.50 & 0.20 & 0.20 & 0.20 & 0.05 & 0.05 & 0.00 & 0.00 & 0.00 & 0.00 \\
\hline \multirow{2}{*}{ Exercise Room } & Weekday & 0.00 & 0.00 & 0.00 & 0.00 & 0.00 & 0.00 & 0.05 & 0.18 & 0.27 & 0.10 & 0.10 & 0.05 & 0.00 & 0.10 & 0.10 & 0.10 & 0.18 & 0.10 & 0.10 & 0.27 & 0.27 & 0.10 & 0.05 & 0.00 \\
\hline & Sat./Sun./Hol. & 0.00 & 0.00 & 0.00 & 0.00 & 0.00 & 0.00 & 0.05 & 0.18 & 0.27 & 0.10 & 0.10 & 0.05 & 0.00 & 0.10 & 0.10 & 0.10 & 0.18 & 0.10 & 0.10 & 0.27 & 0.27 & 0.10 & 0.05 & 0.00 \\
\hline \multirow{2}{*}{ Laundry } & Weekday & 0.00 & 0.00 & 0.00 & 0.00 & 0.00 & 0.00 & 0.00 & 0.00 & 0.09 & 0.18 & 0.18 & 0.18 & 0.00 & 0.18 & 0.18 & 0.18 & 0.09 & 0.00 & 0.00 & 0.00 & 0.00 & 0.00 & 0.00 & 0.00 \\
\hline & Sat./Sun./Hol. & 0.00 & 0.00 & 0.00 & 0.00 & 0.00 & 0.00 & 0.00 & 0.00 & 0.09 & 0.18 & 0.18 & 0.18 & 0.00 & 0.18 & 0.18 & 0.18 & 0.09 & 0.00 & 0.00 & 0.00 & 0.00 & 0.00 & 0.00 & 0.00 \\
\hline
\end{tabular}


Table A.2. Lighting Schedules

\begin{tabular}{|c|c|c|c|c|c|c|c|c|c|c|c|c|c|c|c|c|c|c|c|c|c|c|c|c|c|}
\hline & & 1 & 2 & 3 & 4 & 5 & 6 & 7 & 8 & 9 & 10 & 11 & 12 & 13 & 14 & 15 & 16 & 17 & 18 & 19 & 20 & 21 & 22 & 23 & 24 \\
\hline Space Type & Day Type & $\overline{12-1 \mathrm{a}}$ & $1-2 a$ & $2-3 a$ & $3-4 a$ & $4-5 a$ & $5-6 a$ & $6-7 a$ & $7-8 a$ & $8-9 a$ & $9-10 \mathrm{a}$ & $10-11 \mathrm{a}$ & $11-12 p$ & $12-1 p$ & $1-2 p$ & $2-3 p$ & $3-4 p$ & $4-5 p$ & $5-6 p$ & $6-7 p$ & $7-8 p$ & $8-9 p$ & $9-10 p$ & $10-11 p$ & $\overline{11-12 \mathrm{a}}$ \\
\hline \multirow{2}{*}{ Guest Room (Base) } & Neekday & 0.22 & 0.17 & 11 & 11 & 0.11 & .22 & 0.44 & 0.56 & 44 & 0.28 & 0.28 & 0.28 & 0.28 & 0.28 & 0.28 & 0.28 & 0.35 & 0.40 & 0.67 & 0.89 & 1.00 & 0.89 & 0.67 & 0.33 \\
\hline & Hol. & 0.26 & 0.26 & .11 & 11 & .11 & 11 & 41 & 0.41 & 56 & .45 & .33 & .33 & .33 & 0.33 & .33 & 0.33 & .33 & 0.60 & .85 & 1.00 & 1.00 & 1.00 & .85 & 0.41 \\
\hline \multirow{2}{*}{ Guest Room (Adva) } & Weekdav & 0.11 & 0.09 & .06 & 06 & .06 & .11 & 35 & 0.45 & 35 & 0.05 & .05 & .05 & 0.05 & 0.05 & 0.05 & 0.05 & .08 & 0.10 & .54 & 0.71 & 0.80 & 0.71 & .54 & 0.26 \\
\hline & Hol. & 0.13 & 0.13 & .06 & 06 & .06 & 06 & 33 & 0.33 & 45 & .15 & 05 & .05 & .05 & 0.05 & 0.05 & 0.05 & .05 & 0.15 & 0.68 & 0.80 & 0.80 & 0.80 & .68 & 0.33 \\
\hline \multirow{2}{*}{ Lobby } & Weekday & 0.50 & 50 & .50 & 50 & 0.50 & 0.60 & .00 & 1.00 & .00 & 1.00 & .00 & .00 & .00 & 1.00 & 1.00 & 1.00 & 1.00 & 1.00 & 1.00 & 1.00 & 1.00 & 0.60 & .50 & 0.50 \\
\hline & Hol. & 0.50 & 0.50 & 0.50 & 0.50 & 0.50 & 0.60 & 1.00 & 1.00 & .00 & 1.00 & 1.00 & 1.00 & 1.00 & 1.00 & 1.00 & 1.00 & 1.00 & 1.00 & 1.00 & 1.00 & 1.00 & 0.60 & .50 & 0.50 \\
\hline \multirow{2}{*}{ Office (Base) } & Weekday & 0.50 & 0.50 & 0.50 & 0.50 & 0.50 & 0.50 & 0.50 & 0.61 & .90 & 0.90 & 0.90 & 0.90 & 0.80 & 0.90 & 0.90 & 0.90 & 0.90 & 0.61 & 0.50 & 0.50 & 0.50 & 0.50 & .50 & 0.50 \\
\hline & Sat./su & 0.50 & 0.50 & 0.50 & 0.50 & 0.50 & 0.50 & 0.50 & 0.61 & 0.90 & 0.90 & 0.90 & 0.90 & 0.80 & 0.90 & 0.90 & 0.90 & 0.90 & 0.61 & 0.50 & 0.50 & 0.50 & 0.50 & .50 & 0.50 \\
\hline \multirow{2}{*}{ Office (Adva) } & & 0.43 & 0.43 & 0.43 & 0.43 & 0.43 & 0.43 & 0.43 & 0.52 & 0.77 & 0.77 & 0.77 & 0.77 & 0.68 & 0.77 & 0.77 & 0.77 & 0.77 & 0.52 & 0.43 & 0.43 & 0.43 & 0.43 & .43 & 0.43 \\
\hline & ol. & 0.43 & 0.43 & 0.43 & 0.43 & 0.43 & 0.43 & 0.43 & 0.52 & 0.77 & 0.77 & 0.77 & 0.77 & 0.68 & 0.77 & 0.77 & 0.77 & 0.77 & 0.52 & 0.43 & 0.43 & 0.43 & 0.43 & .43 & 0.43 \\
\hline \multirow{2}{*}{ Employee Lounge } & & 0.05 & 0.05 & 0.05 & 0.05 & 0.05 & 0.15 & 0.40 & 0.50 & 0.70 & 0.70 & 0.70 & .70 & 0.70 & 0.70 & 0.70 & 0.70 & 0.70 & 0.70 & 0.50 & 0.40 & 0.15 & 0.15 & 0.05 & 0.05 \\
\hline & ol. & 0.05 & 0.05 & 0.05 & 0.05 & 0.05 & 0.15 & 0.30 & 0.40 & 0.60 & 0.60 & 0.60 & 0.60 & 0.60 & 0.60 & 0.60 & 0.60 & 0.60 & 0.60 & 0.40 & 0.30 & 0.15 & 0.15 & 0.05 & 0.05 \\
\hline \multirow{2}{*}{ Meeting Room } & & 0.00 & 0.00 & 0.00 & 0.00 & 0.00 & 0.20 & 0.30 & 0.50 & 1.00 & 1.00 & 1.00 & 1.00 & 0.70 & 1.00 & 1.00 & 1.00 & 1.00 & 1.00 & 0.50 & 0.30 & 0.20 & 0.05 & 0.00 & 0.00 \\
\hline & /Hol. & 0.00 & 0.00 & 0.00 & 0.00 & 0.00 & 0.20 & 0.30 & 0.50 & 1.00 & 1.00 & 1.00 & 1.00 & 0.70 & 1.00 & 1.00 & 1.00 & 1.00 & 1.00 & 0.50 & 0.30 & 0.20 & 0.05 & 0.00 & 0.00 \\
\hline \multirow{2}{*}{ Exercise Room (Base) } & Weekday & 0.00 & 0.00 & 0.00 & 0.00 & 0.00 & 0.00 & 0.50 & 1.00 & 1.00 & 1.00 & 1.00 & 1.00 & 1.00 & 1.00 & 1.00 & 1.00 & 1.00 & 1.00 & 1.00 & 1.00 & 1.00 & 1.00 & 0.50 & 0.00 \\
\hline & Sat./Sun./Hol. & 0.00 & 0.00 & 0.00 & 0.00 & 0.00 & 0.00 & 0.50 & 1.00 & 1.00 & 1.00 & 1.00 & 1.00 & 1.00 & 1.00 & 1.00 & 1.00 & 1.00 & 1.00 & 1.00 & 1.00 & 1.00 & 1.00 & 0.50 & 0.00 \\
\hline \multirow{2}{*}{ Exercise Room (Adva) } & Weekday & 0.00 & 0.00 & 0.00 & 0.00 & 0.00 & 0.00 & 0.50 & 0.70 & 0.70 & 0.70 & 0.70 & 0.70 & 0.70 & 0.70 & 0.70 & 0.70 & 0.70 & 0.70 & 0.70 & 0.70 & 0.70 & 0.70 & 0.50 & 0.00 \\
\hline & Sat./Sun./Hol. & 0.00 & 0.00 & 0.00 & 0.00 & 0.00 & 0.00 & 0.50 & 0.70 & 0.70 & 0.70 & 0.70 & 0.70 & 0.70 & 0.70 & 0.70 & 0.70 & 0.70 & 0.70 & 0.70 & 0.70 & 0.70 & 0.70 & 0.50 & 0.00 \\
\hline \multirow{2}{*}{ Restroom (Base) } & Weekda & 1.00 & 1.00 & 1.00 & 1.00 & 1.00 & 1.00 & 1.00 & 1.00 & 1.00 & 1.00 & 1.00 & 1.00 & 1.00 & 1.00 & 1.00 & 1.00 & 1.00 & 1.00 & 1.00 & 1.00 & 1.00 & 1.00 & 1.00 & 1.00 \\
\hline & Sat./S & 1.00 & 1.00 & 1.00 & 1.00 & 1.00 & 1.00 & 1.00 & 1.00 & 1.00 & 1.00 & 1.00 & 1.00 & 1.00 & 1.00 & 1.00 & 1.00 & 1.00 & 1.00 & 1.00 & 1.00 & 1.00 & 1.00 & 1.00 & 1.00 \\
\hline \multirow{2}{*}{ Restroom (Adva) } & Weekda & 0.10 & 0.10 & 0.10 & 0.10 & 0.30 & 0.50 & 0.85 & 0.95 & 0.95 & 0.95 & 0.95 & 0.95 & 0.95 & 0.95 & 0.95 & 0.95 & 0.95 & 0.95 & 0.95 & 0.95 & 0.95 & 0.95 & 0.85 & 0.50 \\
\hline & Sat./Sun./Hol. & 0.10 & 0.10 & 0.10 & 0.10 & 0.30 & 0.50 & 0.85 & 0.95 & 0.95 & 0.95 & 0.95 & 0.95 & 0.95 & 0.95 & 0.95 & 0.95 & 0.95 & 0.95 & 0.95 & 0.95 & 0.95 & 0.95 & 0.85 & 0.50 \\
\hline \multirow{2}{*}{$\begin{array}{l}\text { Laundry Room } \\
\text { (Base) }\end{array}$} & Weekd & 0.00 & 0.00 & 0.00 & 0.00 & 0.00 & 0.00 & 0.00 & 0.00 & 1.00 & 1.00 & 1.00 & 1.00 & 1.00 & 1.00 & 1.00 & 1.00 & 1.00 & 0.00 & 0.00 & 0.00 & 0.00 & 0.00 & 0.00 & 0.00 \\
\hline & Sat./Sun./Hol. & 0.00 & 0.00 & 0.00 & 0.00 & 0.00 & 0.00 & 0.00 & 0.00 & 1.00 & 1.00 & 1.00 & 1.00 & 1.00 & 1.00 & 1.00 & 1.00 & 1.00 & 0.00 & 0.00 & 0.00 & 0.00 & 0.00 & 0.00 & 0.00 \\
\hline \multirow{2}{*}{$\begin{array}{l}\text { Laundry Room } \\
\text { (Adva) }\end{array}$} & Weekd & 0.00 & 0.00 & 0.00 & 0.00 & 0.00 & 0.00 & 0.00 & 0.00 & 0.85 & 0.85 & 0.85 & 0.85 & 0.85 & 0.85 & 0.85 & 0.85 & 0.85 & 0.00 & 0.00 & 0.00 & 0.00 & 0.00 & 0.00 & 0.00 \\
\hline & t./Sun./Hol. & 0.00 & 0.00 & 0.00 & 0.00 & 0.00 & 0.00 & 0.00 & 0.00 & 0.85 & 0.85 & 0.85 & 0.85 & 0.85 & 0.85 & 0.85 & 0.85 & 0.85 & 0.00 & 0.00 & 0.00 & 0.00 & 0.00 & 0.00 & 0.00 \\
\hline \multirow{2}{*}{$\begin{array}{l}\text { Storage /Mechanical } \\
\text { (Base) }\end{array}$} & Weekda & 0.10 & 0.10 & 0.10 & 0.10 & 0.10 & 0.10 & 0.10 & 0.20 & 0.40 & 0.40 & 0.40 & 0.40 & 0.40 & 0.40 & 0.40 & 0.40 & 0.40 & 0.40 & 0.20 & 0.20 & 0.20 & 0.20 & 0.10 & 0.10 \\
\hline & Sat./Sun./l & 0.10 & 0.10 & 0.10 & 0.10 & 0.10 & 0.10 & 0.10 & 0.20 & 0.40 & 0.40 & 0.40 & 0.40 & 0.40 & 0.40 & 0.40 & 0.40 & 0.40 & 0.40 & 0.20 & 0.20 & 0.20 & 0.20 & 0.10 & 0.10 \\
\hline \multirow{2}{*}{$\begin{array}{l}\text { Storage /Mechanical } \\
\text { (Adva) }\end{array}$} & Weekd & 0.06 & 0.06 & 0.06 & 0.06 & 0.06 & 0.06 & 0.06 & 0.12 & 0.24 & 0.24 & 0.24 & 0.24 & 0.24 & 0.24 & 0.24 & 0.24 & 0.24 & 0.24 & 0.12 & 0.12 & 0.12 & 0.12 & 0.06 & 0.06 \\
\hline & Sat./Sun./H & 0.06 & 0.06 & 0.06 & 0.06 & 0.06 & 0.06 & 0.06 & 0.12 & 0.24 & 0.24 & 0.24 & 0.24 & 0.24 & 0.24 & 0.24 & 0.24 & 0.24 & 0.24 & 0.12 & 0.12 & 0.12 & 0.12 & 0.06 & 0.06 \\
\hline Stairs & & 1.00 & 1.00 & 1.00 & 1.00 & 1.00 & 1.00 & 1.0 & 1.00 & 1.00 & 1.00 & 1.0 & 1. & 1.00 & 1.00 & 1.00 & 1.00 & 1.00 & 1.00 & 1.00 & 1.00 & 1.00 & 1.00 & 1.00 & 1.00 \\
\hline (Base) & Sat./Sun./H & 1.00 & 1.00 & 1.00 & 1.00 & 1.00 & 1.00 & 1.0 & 1.00 & 1.00 & 1.00 & 1. & 1.00 & 1.00 & 1.00 & 1.00 & 1.00 & 1.00 & 1.00 & 1.00 & 1.00 & 1.00 & 1.00 & 1.00 & 1.00 \\
\hline & & 0.30 & 0.30 & 0.30 & 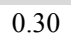 & 0.30 & & 20 & 0.80 & 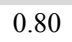 & 0.8 & 0. & 0. & 0.6 & 0.60 & 0.60 & 0.60 & 0.80 & 0.80 & 0.80 & 0.80 & 0.80 & 0.80 & 0.60 & 0.60 \\
\hline & & 0.30 & 0.30 & 0.30 & & 0.30 & & $0.0+8$ & 0.80 & 0.80 & 0.80 & 0.7 & 0.60 & 0.60 & 0.60 & 0.60 & 0.60 & 0.80 & 0.80 & 0.80 & 0.80 & 0.80 & 0.80 & 0.60 & 0.60 \\
\hline & & 1.00 & 1.00 & 1.00 & 1.00 & 1.00 & 1.00 & 1.0 & 1.00 & 1.0 & 1.00 & 1.0 & 1.00 & 1.00 & 1.00 & 1.00 & 1.00 & 1.00 & 1.00 & 1.00 & 1.00 & 1.00 & 1.00 & 1.00 & 1.00 \\
\hline & /Hol. & 1.00 & 1.00 & 1.00 & 1.00 & 1.00 & 1.00 & 1.00 & 1.00 & 1.00 & 1.00 & 1.0 & 1.00 & 1.00 & 1.00 & 1.00 & 1.00 & 1.00 & 1.00 & 1.00 & 1.00 & 1.00 & 1.00 & 1.00 & 1.00 \\
\hline torion & W & 1.00 & 1.00 & 1.00 & 1.0 & 1.00 & 1.00 & 1.00 & 0.00 & 0.0 & 0.00 & 0.0 & 0.00 & 0.00 & 0.00 & 0.00 & 0.00 & 0.00 & 0.00 & 0.00 & 1.00 & 1.00 & 1.00 & 1.00 & 1.00 \\
\hline & Sat./Sun./F & 1.00 & 1.00 & 1.00 & 1.00 & 1.00 & 1.00 & 1.00 & 0.00 & 0.0 & 0.00 & 0.0 & 0.00 & 0.00 & 0.00 & 0.00 & 0.00 & 0.00 & 0.00 & 0.00 & 1.00 & 1.00 & 1.00 & 1.00 & 1.00 \\
\hline & Weekd & 0.52 & 0.52 & 0.52 & 0.5 & 0.52 & 1.00 & 1.00 & 0.00 & 0.0 & 0.00 & 0.0 & 0.00 & 0.00 & 0.00 & 0.00 & 0.00 & 0.00 & 0.00 & 0.00 & 1.00 & 1.00 & 1.00 & 1.00 & 1.00 \\
\hline & Sat./Sun./Hol. & 0.52 & 0.52 & 0.52 & 0.52 & 0.52 & 1.00 & 1.00 & 0.00 & 0.00 & 0.00 & 0.00 & 0.00 & 0.00 & 0.00 & 0.00 & 0.00 & 0.00 & 0.00 & 0.00 & 1.00 & 1.00 & 1.00 & 1.00 & 1.00 \\
\hline
\end{tabular}


Table A.3. Plug Loads Schedules

\begin{tabular}{|c|c|c|c|c|c|c|c|c|c|c|c|c|c|c|c|c|c|c|c|c|c|c|c|c|c|}
\hline \multirow{2}{*}{ Space Type } & \multirow{2}{*}{ Day Type } & 1 & 2 & 3 & 4 & 5 & 6 & 7 & 8 & 9 & 10 & 11 & 12 & 13 & 14 & 15 & 16 & 17 & 18 & 19 & 20 & 21 & 22 & 23 & 24 \\
\hline & & $12-1 \mathrm{a}$ & $1-2 a$ & $2-3 a$ & $3-4 a$ & $4-5 a$ & $5-6 a$ & $6-7 a$ & $7-8 \mathrm{a}$ & $8-9 a$ & $9-10 \mathrm{a}$ & $10-11 \mathrm{a}$ & $11-12 p$ & $12-1 p$ & $1-2 p$ & $2-3 p$ & $3-4 p$ & $4-5 p$ & $5-6 p$ & $6-7 \mathrm{p}$ & $7-8 p$ & $8-9 p$ & $9-10 p$ & $10-11 p$ & $11-12 \mathrm{a}$ \\
\hline \multirow{2}{*}{$\begin{array}{l}\text { Guest Room } \\
\text { (Base) }\end{array}$} & Weekday & 0.12 & 0.12 & 0.12 & 0.12 & 0.12 & 0.30 & 0.62 & 0.87 & 0.43 & 0.22 & 0.22 & 0.22 & 0.22 & 0.22 & 0.22 & 0.22 & 0.28 & 0.34 & 0.34 & 0.32 & 0.32 & 0.60 & 0.50 & 0.32 \\
\hline & Hol. & 0.12 & 0.12 & 0.12 & 0.12 & 0.12 & 0.12 & 30 & 0.62 & 0.87 & 0.62 & 0.22 & 0.22 & 0.22 & 0.22 & 0.22 & 0.22 & 0.28 & 0.32 & 0.34 & 0.32 & 0.32 & 0.60 & 0.50 & 0.32 \\
\hline \multirow{2}{*}{$\begin{array}{l}\text { Guest Room } \\
\text { (Adva) }\end{array}$} & Weekday & 0.10 & 0.10 & 0.10 & 0.10 & 0.10 & 0.30 & 0.62 & 0.87 & 0.43 & 0.10 & 0.10 & 0.10 & 0.10 & 0.10 & 0.10 & 0.10 & 0.20 & 0.32 & 0.32 & 0.30 & 0.30 & 0.59 & 0.48 & 0.30 \\
\hline & Sat./Sun./Hol. & 0.10 & 0.10 & 0.10 & 0.10 & 0.10 & 0.10 & 0.30 & 0.62 & 0.87 & 0.62 & 0.10 & 0.10 & 0.10 & 0.10 & 0.10 & 0.10 & 0.20 & 0.30 & 0.32 & 0.30 & 0.30 & 0.59 & 0.48 & 0.30 \\
\hline \multirow[t]{2}{*}{ Lobby } & Weekday & 0.21 & 0.21 & 0.21 & 0.21 & 0.21 & 0.68 & 1.00 & 1.00 & 1.00 & 1.00 & 0.32 & 0.23 & 0.23 & 0.23 & 0.23 & 0.23 & 0.23 & 0.23 & 0.23 & 0.23 & 0.23 & 0.23 & 0.23 & 0.21 \\
\hline & Sat./Sun./Hol. & 0.21 & 0.21 & 0.21 & 0.21 & 0.21 & 0.68 & 1.00 & 1.00 & 1.00 & 1.00 & 0.32 & 0.23 & 0.23 & 0.23 & 0.23 & 0.23 & 0.23 & 0.23 & 0.23 & 0.23 & 0.23 & 0.23 & 0.23 & 0.21 \\
\hline \multirow{2}{*}{$\begin{array}{l}\text { Office } \\
\text { (Base) }\end{array}$} & Weekday & 0.33 & 0.33 & 0.33 & 0.33 & 0.33 & 0.38 & 0.38 & 0.43 & 1.00 & 1.00 & 1.00 & 1.00 & 0.94 & 1.00 & 1.00 & 1.00 & 1.00 & 0.75 & 0.63 & 0.63 & 0.48 & 0.48 & 0.33 & 0.33 \\
\hline & Sat./Sun./Hol. & 0.33 & 0.33 & 0.33 & 0.33 & 0.33 & 0.38 & 0.38 & 0.43 & 0.63 & 0.63 & 0.63 & 0.63 & 0.63 & 0.63 & 0.63 & 0.63 & 0.63 & 0.63 & 0.48 & 0.48 & 0.48 & 0.48 & 0.33 & 0.33 \\
\hline \multirow{2}{*}{$\begin{array}{l}\text { Office } \\
\text { (Adva) }\end{array}$} & Weekday & 0.26 & 0.26 & 0.26 & 0.26 & 0.26 & 0.30 & 0.30 & 0.37 & 0.96 & 0.96 & 0.96 & 0.96 & 0.90 & 0.96 & 0.96 & 0.96 & 0.96 & 0.71 & 0.60 & 0.54 & 0.38 & 0.38 & 0.26 & 0.26 \\
\hline & Sat./Sun./Hol. & 0.25 & 0.25 & 0.25 & 0.25 & 0.25 & 0.29 & 0.29 & 0.32 & 0.50 & 0.50 & 0.50 & 0.50 & 0.50 & 0.50 & 0.50 & 0.50 & 0.50 & 0.50 & 0.36 & 0.36 & 0.36 & 0.36 & 0.25 & 0.25 \\
\hline \multirow[t]{2}{*}{ Employee Lounge } & Weekday & 0.11 & 0.11 & 0.11 & 0.11 & 0.11 & 0.19 & 0.19 & 0.25 & 1.00 & 1.00 & 0.86 & 0.86 & 1.00 & 0.86 & 0.86 & 0.86 & 0.86 & 0.86 & 0.25 & 0.19 & 0.11 & 0.11 & 0.11 & 0.11 \\
\hline & Sat./Sun./Hol. & 0.11 & 0.11 & 0.11 & 0.11 & 0.11 & 0.19 & 0.19 & 0.25 & 1.00 & 1.00 & 0.86 & 0.86 & 1.00 & 0.86 & 0.86 & 0.86 & 0.86 & 0.86 & 0.25 & 0.19 & 0.11 & 0.11 & 0.11 & 0.11 \\
\hline \multirow[t]{2}{*}{ Meeting Room } & Weekday & 0.00 & 0.00 & 0.00 & 0.00 & 0.00 & 0.00 & 0.00 & 0.05 & 0.54 & 0.54 & 0.26 & 0.26 & 0.05 & 0.54 & 0.54 & 0.26 & 0.26 & 0.26 & 0.05 & 0.05 & 0.00 & 0.00 & 0.00 & 0.00 \\
\hline & Sat./Sun./Hol. & 0.00 & 0.00 & 0.00 & 0.00 & 0.00 & 0.00 & 0.00 & 0.05 & 0.54 & 0.54 & 0.26 & 0.26 & 0.05 & 0.54 & 0.54 & 0.26 & 0.26 & 0.26 & 0.05 & 0.05 & 0.00 & 0.00 & 0.00 & 0.00 \\
\hline \multirow[t]{2}{*}{ Exercise Room } & Weekday & 0.00 & 0.00 & 0.00 & 0.00 & 0.00 & 0.00 & 0.50 & 1.00 & 1.00 & 0.50 & 0.50 & 0.50 & 0.00 & 0.50 & 0.50 & 0.50 & 1.00 & 0.50 & 0.50 & 1.00 & 1.00 & 0.50 & 0.50 & 0.00 \\
\hline & Sat./Sun./Hol. & 0.00 & 0.00 & 0.00 & 0.00 & 0.00 & 0.00 & 0.50 & 1.00 & 1.00 & 50 & 0.50 & 0.50 & 0.00 & 0.50 & 0.50 & 0.50 & 1.00 & 0.50 & 0.50 & 1.00 & 1.00 & 0.50 & 0.50 & 0.00 \\
\hline \multirow[t]{2}{*}{ Laundry Room-Washer } & Weekday & 0.00 & 0.00 & 0.00 & 0.00 & 0.00 & 0.00 & 0.00 & 1.00 & 1.00 & 1.00 & 1.00 & 1.00 & 1.00 & 1.00 & 1.00 & 0.00 & 0.00 & 0.00 & 0.00 & 0.00 & 0.00 & 0.00 & 0.00 & 0.00 \\
\hline & Sat./Sun./Hol. & 0.00 & 0.00 & 0.00 & 0.00 & 0.00 & 0.00 & 0.00 & 1.00 & 1.00 & 1.00 & 1.00 & 1.00 & 1.00 & 1.00 & 1.00 & 0.00 & 0.00 & 0.00 & 0.00 & 0.00 & 0.00 & 0.00 & 0.00 & 0.00 \\
\hline \multirow[t]{2}{*}{ Laundry Room-Dryer } & Weekday & 0.00 & 0.00 & 0.00 & 0.00 & 0.00 & 0.00 & 0.00 & 0.00 & 1.00 & 1.00 & 1.00 & 1.00 & 1.00 & 1.00 & 1.00 & 1.00 & 0.00 & 0.00 & 0.00 & 0.00 & 0.00 & 0.00 & 0.00 & 0.00 \\
\hline & Sat./Sun./Hol. & 0.00 & 0.00 & 0.00 & 0.00 & 0.00 & 0.00 & 0.00 & 0.00 & 1.00 & 1.00 & 1.00 & 1.00 & 1.00 & 1.00 & 1.00 & 1.00 & 0.00 & 0.00 & 0.00 & 0.00 & 0.00 & 0.00 & 0.00 & 0.00 \\
\hline \multirow[t]{2}{*}{ Elevator } & Weekday & 0.05 & 0.05 & 0.05 & 0.05 & 0.10 & 0.20 & 0.40 & 0.50 & 0.50 & 0.35 & 0.15 & 0.15 & 0.15 & 0.15 & 0.15 & 0.15 & 0.35 & 0.50 & 0.50 & 0.40 & 0.40 & 0.30 & 0.20 & 0.10 \\
\hline & Sat./Sun./Hol. & 0.05 & 0.05 & 0.05 & 0.05 & 0.10 & 0.15 & 0.20 & 0.40 & 0.50 & 0.50 & 0.35 & 0.15 & 0.15 & 0.15 & 0.15 & 0.15 & 0.35 & 0.50 & 0.50 & 0.40 & 0.40 & 0.30 & 0.20 & 0.10 \\
\hline
\end{tabular}


Table A.4. HVAC and SWH Schedules

\begin{tabular}{|c|c|c|c|c|c|c|c|c|c|c|c|c|c|c|c|c|c|c|c|c|c|c|c|c|c|}
\hline \multirow{2}{*}{ Space Type } & \multirow{2}{*}{ Day Type } & 1 & 2 & 3 & 4 & 5 & 6 & 7 & 8 & 9 & 10 & 11 & 12 & 13 & 14 & 15 & 16 & 17 & 18 & 19 & 20 & 21 & 22 & 23 & 24 \\
\hline & & $\overline{12-1 \mathrm{a}}$ & $1-2 a$ & $2-3 a$ & $3-4 a$ & $4-5 a$ & $5-6 a$ & $6-7 a$ & $7-8 \mathrm{a}$ & $8-9 a$ & $9-10 \mathrm{a}$ & $10-11 \mathrm{a} 1$ & $11-12 p$ & $12-1 p$ & $1-2 p$ & $2-3 p$ & $3-4 p$ & $4-5 p$ & $5-6 p$ & $6-7 p$ & $7-8 p$ & $8-9 p$ & $9-10 p$ & $10-11 \mathrm{p}$ & $11-12 \mathrm{a}$ \\
\hline Rented Guest & Weekday & 1 & 1 & 1 & 1 & 1 & 1 & 1 & 1 & 1 & 1 & 1 & 1 & 1 & 1 & 1 & 1 & 1 & 1 & 1 & 1 & 1 & 1 & 1 & 1 \\
\hline $\begin{array}{l}\text { Room -HVAC } \\
\text { (Base) }\end{array}$ & Sat/Sun/Hol & 1 & 1 & 1 & 1 & 1 & 1 & 1 & 1 & 1 & 1 & 1 & 1 & 1 & 1 & 1 & 1 & 1 & 1 & 1 & 1 & 1 & 1 & 1 & 1 \\
\hline $\begin{array}{l}\text { Rented Guest } \\
\text { Room -HVAC }\end{array}$ & Weekday & 1 & 1 & 1 & 1 & 1 & 1 & 1 & 1 & 1 & 0 & 0 & 0 & 0 & 0 & 0 & 0 & 1 & 1 & 1 & 1 & 1 & 1 & 1 & 1 \\
\hline (Adva) & Sat./Sun./Hol. & 1 & 1 & 1 & 1 & 1 & 1 & 1 & 1 & 1 & 1 & 0 & 0 & 0 & 0 & 0 & 0 & 0 & 1 & 1 & 1 & 1 & 1 & 1 & 1 \\
\hline $\begin{array}{l}\text { Vacant Guest } \\
\text { Room -HVAC }\end{array}$ & Weekday & 1 & 1 & 1 & 1 & 1 & 1 & 1 & 1 & 1 & 1 & 1 & 1 & 1 & 1 & 1 & 1 & 1 & 1 & 1 & 1 & 1 & 1 & 1 & 1 \\
\hline (Base) & Sat./Sun./Hol. & 1 & 1 & 1 & 1 & 1 & 1 & 1 & 1 & 1 & 1 & 1 & 1 & 1 & 1 & 1 & 1 & 1 & 1 & 1 & 1 & 1 & 1 & 1 & 1 \\
\hline $\begin{array}{l}\text { Vacant Guest } \\
\text { Room -HVAC }\end{array}$ & Weekday & 0 & 0 & 0 & 0 & 0 & 0 & 0 & 0 & 0 & 0 & 0 & 0 & 0 & 0 & 0 & 0 & 0 & 0 & 0 & 0 & 0 & 0 & 0 & 0 \\
\hline (Adva) & Sat./Sun./Hol. & 0 & 0 & 0 & 0 & 0 & 0 & 0 & 0 & 0 & 0 & 0 & 0 & 0 & 0 & 0 & 0 & 0 & 0 & 0 & 0 & 0 & 0 & 0 & 0 \\
\hline $\begin{array}{l}\text { Meeting Room } \\
\text { - HVAC }\end{array}$ & Weekday & 1 & 1 & 1 & 1 & 1 & 1 & 1 & 1 & 1 & 1 & 1 & 1 & 1 & 1 & 1 & 1 & 1 & 1 & 1 & 1 & 1 & 1 & 1 & 1 \\
\hline (Base) & Sat./Sun./Hol. & 1 & 1 & 1 & 1 & 1 & 1 & 1 & 1 & 1 & 1 & 1 & 1 & 1 & 1 & 1 & 1 & 1 & 1 & 1 & 1 & 1 & 1 & 1 & 1 \\
\hline Meeting Room & Weekday & 0 & 0 & 0 & 0 & 0 & 0 & 0 & 1 & 1 & 1 & 1 & 1 & 1 & 1 & 1 & 1 & 1 & 1 & 1 & 0 & 0 & 0 & 0 & 0 \\
\hline $\begin{array}{l}\text { - HVAC } \\
\text { (Adva) }\end{array}$ & Sat./Sun./Hol. & 0 & 0 & 0 & 0 & 0 & 0 & 0 & 1 & 1 & 1 & 1 & 1 & 1 & 1 & 1 & 1 & 1 & 1 & 1 & 0 & 0 & 0 & 0 & 0 \\
\hline $\begin{array}{l}\text { Exercise } \\
\text { Employee Lounge }\end{array}$ & Weekday & 1 & 1 & 1 & 1 & 1 & 1 & 1 & 1 & 1 & 1 & 1 & 1 & 1 & 1 & 1 & 1 & 1 & 1 & 1 & 1 & 1 & 1 & 1 & 1 \\
\hline $\begin{array}{l}\text { Restroom - HVAC } \\
\text { (Base) }\end{array}$ & Sat./Sun./Hol. & 1 & 1 & 1 & 1 & 1 & 1 & 1 & 1 & 1 & 1 & 1 & 1 & 1 & 1 & 1 & 1 & 1 & 1 & 1 & 1 & 1 & 1 & 1 & 1 \\
\hline $\begin{array}{l}\text { Exercise } \\
\text { Employee }\end{array}$ & Weekday & 0 & 0 & 0 & 0 & 0 & 0 & 1 & 1 & 1 & 1 & 1 & 1 & 1 & 1 & 1 & 1 & 1 & 1 & 1 & 1 & 1 & 1 & 1 & 0 \\
\hline $\begin{array}{l}\text { Lounge_- } \\
\text { Restroom-HVAC } \\
\text { (Adva) }\end{array}$ & Sat./Sun./Hol. & 0 & 0 & 0 & 0 & 0 & 0 & 1 & 1 & 1 & 1 & 1 & 1 & 1 & 1 & 1 & 1 & 1 & 1 & 1 & 1 & 1 & 1 & 1 & 0 \\
\hline Other Public & Weekday & 1 & 1 & 1 & 1 & 1 & 1 & 1 & 1 & 1 & 1 & 1 & 1 & 1 & 1 & 1 & 1 & 1 & 1 & 1 & 1 & 1 & 1 & 1 & 1 \\
\hline Spaces -HVAC & Sat./Sun./Hol. & 1 & 1 & 1 & 1 & 1 & 1 & 1 & 1 & 1 & 1 & 1 & 1 & 1 & 1 & 1 & 1 & 1 & 1 & 1 & 1 & 1 & 1 & 1 & 1 \\
\hline Guest Room & Weekday & 0.20 & 0.15 & 0.15 & 0.15 & 0.20 & 0.35 & 0.60 & 0.80 & 0.55 & 0.40 & 0.30 & 0.20 & 0.20 & 0.20 & 0.20 & 0.20 & 0.20 & 0.30 & 0.40 & 0.40 & 0.40 & 0.60 & 0.45 & 0.25 \\
\hline (SWH) & Sat./Sun./Hol. & 0.20 & 0.15 & 0.15 & 0.15 & 0.20 & 0.25 & 0.35 & 0.60 & 0.80 & 0.55 & 0.40 & 0.30 & 0.20 & 0.20 & 0.20 & 0.20 & 0.20 & 0.25 & 0.30 & 0.40 & 0.40 & 0.40 & 0.60 & 0.35 \\
\hline Laundry Room & Weekday & 0.00 & 0.00 & 0.00 & 0.00 & 0.00 & 0.00 & 0.00 & 1.00 & 1.00 & 1.00 & 1.00 & 1.00 & 1.00 & 1.00 & 1.00 & 0.00 & 0.00 & 0.00 & 0.00 & 0.00 & 0.00 & 0.00 & 0.00 & 0.00 \\
\hline$(\mathrm{SWH})$ & Sat./Sun./Hol. & 0.00 & 0.00 & 0.00 & 0.00 & 0.00 & 0.00 & 0.00 & 1.00 & 1.00 & 1.00 & 1.00 & 1.00 & 1.00 & 1.00 & 1.00 & 0.00 & 0.00 & 0.00 & 0.00 & 0.00 & 0.00 & 0.00 & 0.00 & 0.00 \\
\hline
\end{tabular}


Appendix B

\section{Building Prototypes Model Assumptions}


Table B.1. Highway Lodging Prototype Assumptions

\begin{tabular}{|c|c|c|}
\hline Characteristic & Prototype Assumption & Data Source/Remarks \\
\hline \multicolumn{3}{|l|}{ GENERAL } \\
\hline Building Type & Highway Lodging & \\
\hline Location & 16 Climate Cities & \\
\hline Gross Area, $\mathrm{ft}^{2}\left(\mathrm{~m}^{2}\right)$ & $43,200(3,995)$ & $\begin{array}{l}\text { Hampton Inn Prototype, Version 5.1/Sept.-2004 } \\
\text { (referred as: Hampton Inn Prototype) } \\
\text { F.W. Dodge Data }\end{array}$ \\
\hline Operation Hours & $24 / 7$ & General Practice \\
\hline Space Types & Guest Room: $63 \%$ & Hampton Inn Prototype \\
\hline & Lobby: $5 \%$ & \\
\hline & Laundry: 6\% & \\
\hline & Corridor: $13 \%$ & \\
\hline Number of Guest Room & 77 (assume $65 \%$ occupancy rate) & Hampton Inn Prototype \\
\hline Area of Guest Room, $\mathrm{ft}^{2}\left(\mathrm{~m}^{2}\right)$ & $351(33)$ & Hampton Inn Prototype \\
\hline \multicolumn{3}{|l|}{ ARCHITECTURAL FEATURES } \\
\hline \multicolumn{3}{|l|}{ Configuration/Shape } \\
\hline Building Shape & Wide-rectangle & Hampton Inn Prototype \\
\hline Number of Floors & 4 & Hampton Inn Prototype \\
\hline Window to Wall Ratio & $11 \%$ & Hampton Inn Prototype \\
\hline Floor-to-Ceiling Height & $11 \mathrm{ft}$ ground floor, $9 \mathrm{ft}$ typical floor & Hampton Inn Prototype \\
\hline Floor-to-Floor Height & Same as floor-to-ceiling height & Hampton Inn Prototype \\
\hline $\begin{array}{l}\text { Infiltration Rate, } \mathrm{cfm} / \mathrm{ft}^{2}\left(\mathrm{~m}^{3} / \mathrm{s} /\right. \\
\left.\mathrm{m}^{2}\right)\end{array}$ & $0.2016(0.001024)$ & PNNL Study \\
\hline Infiltration Schedule & $\begin{array}{l}\text { full infiltration when the HVAC system is off and } 25 \% \\
\text { infiltration when the HVAC system is on }\end{array}$ & PNNL Study \\
\hline \multicolumn{3}{|l|}{ Exterior Walls } \\
\hline Gross Wall Area, $\mathrm{ft}^{2}\left(\mathrm{~m}^{2}\right)$ & $18,240(1,695)$ & \\
\hline Structure & Mass wall/ 8" Concrete Block wall & AEDG-HL Committee's Inputs \\
\hline Exterior Finish & None & \\
\hline \multicolumn{3}{|l|}{ Roof } \\
\hline Gross Roof Area, $\mathrm{ft}^{2}\left(\mathrm{~m}^{2}\right)$ & $10,800(1,003)$ & \\
\hline Structure & Steel deck with rigid insulation & AEDG-HL Committee's Inputs \\
\hline Exterior Finish & Single-ply roof membrane & AEDG-HL Committee's Inputs \\
\hline \multicolumn{3}{|l|}{ Fenestration/Windows } \\
\hline $\begin{array}{l}\text { Total Fenestration Area, } \mathrm{ft}^{2} \\
\left(\mathrm{~m}^{2}\right)\end{array}$ & $\begin{array}{l}1,985(184) \\
\text { Typical window size is } 4 \mathrm{ft} \times 5 \mathrm{ft}(1.2 \mathrm{~m} \times 1.5 \mathrm{~m})\end{array}$ & Hampton Inn Prototype \\
\hline
\end{tabular}




\begin{tabular}{lll}
\hline \multicolumn{1}{c}{ Characteristic } & \multicolumn{1}{c}{ Prototype Assumption } & \multicolumn{1}{c}{ Data Source/Remarks } \\
\hline Window & None & Hampton Inn Prototype \\
Shading/Overhangs & N.A. (all doors are glazed, treated as fenestration) & 2003 CBECS \\
Opaque Doors & No & Hampton Inn Prototype \\
Skylights & Hampton Inn Prototype \\
\hline
\end{tabular}




\section{Appendix C}

Baseline and Advanced Buildings Model Assumptions 
Table C.1. Baseline and Advanced Buildings Model Assumptions

\begin{tabular}{|c|c|c|c|c|c|}
\hline \multicolumn{2}{|l|}{ Characteristic } & 90.1-2004 Baseline & \multicolumn{2}{|c|}{$50 \%$ Design Package } & Data Source/Remarks \\
\hline \multicolumn{6}{|l|}{$\begin{array}{l}\text { ARCHITECTURAL FEATURES } \\
\end{array}$} \\
\hline \multicolumn{6}{|l|}{ Exterior Walls } \\
\hline $\begin{array}{l}\text { Insulation (Res/NonRes), } \\
{ }^{\circ} \mathrm{F} \cdot \mathrm{h} \cdot \mathrm{ft}^{2} / \mathrm{Btu}\left(\mathrm{K} \cdot \mathrm{m}^{2} / \mathrm{W}\right)\end{array}$ & $\begin{array}{l}\text { Zone 1, 2: } \\
\text { Zone 3: } \\
\text { Zone 4: } \\
\text { Zone 5: } \\
\text { Zone 6: } \\
\text { Zone 7: } \\
\text { Zone 8: }\end{array}$ & $\begin{array}{l}\text { R-5.7 c.i./NR (R-1.0 c.i./NR) } \\
\text { R-7.6 c.i./R-5.7 c.i.(R-1.3 c.i./ } \\
\text { R-1.0 c.i.) } \\
\text { R-9.5 c.i./R-5.7 c.i. (R-1.7 c.i./ } \\
\text { R-1.0 c.i.) } \\
\text { R-11.4 c.i./R-7.6 c.i. (R-2.0 } \\
\text { c.i./ R-1.3 c.i.) } \\
\text { R-11.4 c.i./R-9.5 c.i. (R-2.0 } \\
\text { c.i./ R-1.7 c.i.) } \\
\text { R-13.3 c.i./R-11.4 c.i. (R-2.3 } \\
\text { c.i./R-2.0 c.i.) } \\
\text { R-15.2 c.i./ R-13.3 c.i. (R-2.7 } \\
\text { c.i./R-2.3 c.i.) }\end{array}$ & $\begin{array}{l}\text { Zone 1: } \\
\text { Zone 2: } \\
\text { Zone 3: } \\
\text { Zone 4: } \\
\text { Zone 5,6,7,8: }\end{array}$ & $\begin{array}{l}\text { R-5.7 c.i. (R-1.0 c.i.) } \\
\text { R-7.6 c.i. (R-1.3 c.i.) } \\
\text { R-11.4 c.i. (R-2.0 c.i.) } \\
\text { R-13.3 c.i. (R-2.3 c.i.) } \\
\text { R-19.5 c.i. (R-3.4 c.i.) }\end{array}$ & $\begin{array}{l}\text { Base: ASHRAE } 90.1-2004 \\
50 \% \text { DP: AEDG-HL and 90.1- } \\
2007 \text { Addenda 'bb' }\end{array}$ \\
\hline $\begin{array}{l}\text { Overall U-factor, } \\
\mathrm{Btu} /{ }^{\circ} \mathrm{F} \cdot \mathrm{h} \cdot \mathrm{ft}^{2}\left(\mathrm{~W} / \mathrm{K} \cdot \mathrm{m}^{2}\right)\end{array}$ & $\begin{array}{l}\text { Zone 1, 2: } \\
3.293 \text { ) } \\
\text { Zone 3: } \\
0.857) \\
\text { Zone 4: } \\
\text { U-0.857) } \\
\text { Zone 5: } \\
0.698) \\
\text { Zone 6: } \\
0.591) \\
\text { Zone 7: } \\
0.511) \\
\text { Zone 8: } \\
0.454)\end{array}$ & $\begin{array}{l}\text { U-0.151/U-0.58 (U-0.857/U- } \\
\text { U-0.123/U-0.151 (U-0.698/U- } \\
\text { U-0.104/ U-0.151 (U-0.591/ } \\
\text { U-0.090/ U-0.123 (U-0.511/U- } \\
\text { U-0.090/ U-0.104 (U-0.511/U- } \\
\text { U-0.080/ U-0.090 (U-0.454/U- } \\
\text { U-0.071/ U-0.080 (U-0.403/U- }\end{array}$ & $\begin{array}{l}\text { Zone 1: } \\
\text { Zone 2: } \\
\text { Zone 3: } \\
\text { Zone } 4: \\
\text { Zone 5,6,7,8 }\end{array}$ & $\begin{array}{l}\text { U-0.151 (U-0.857) } \\
\text { U-0.123 (U-0.698) } \\
\text { U-0.090 (U-0.511) } \\
\text { U-0.080 (U-0.454) } \\
\text { U-0.047 (U-0.267) }\end{array}$ & $\begin{array}{l}\text { ASHRAE 90.1-2007 Table } 5.5 \\
(1-8) \text { and Appendix-A-3.1 }\end{array}$ \\
\hline \multicolumn{6}{|l|}{ Roof } \\
\hline $\begin{array}{l}\text { Insulation (Res), } \\
{ }^{\circ} \mathrm{F} \cdot \mathrm{h} \cdot \mathrm{ft}^{2} / \mathrm{Btu}\left(\mathrm{K} \cdot \mathrm{m}^{2} / \mathrm{W}\right)\end{array}$ & $\begin{array}{l}\text { Zones 1-7: } \\
\text { Zone 8: }\end{array}$ & $\begin{array}{l}\text { R-15 c.i. (R-2.6 c.i.) } \\
\text { R-20 c.i. (R-3.5 c.i.) }\end{array}$ & $\begin{array}{l}\text { Zones 1,2,3: } \\
\text { Zone 4,5,6: } \\
\text { Zone 7,8: }\end{array}$ & $\begin{array}{l}\text { R-25 c.i. (R-4.4 c.i.) } \\
\text { R-30 c.i. (R-5.3 c.i.) } \\
\text { R-35 c.i. (R-6.2 c.i.) }\end{array}$ & $\begin{array}{l}\text { Base: ASHRAE } 90.1-2004 \\
50 \% \text { DP: AEDG-HL }\end{array}$ \\
\hline
\end{tabular}




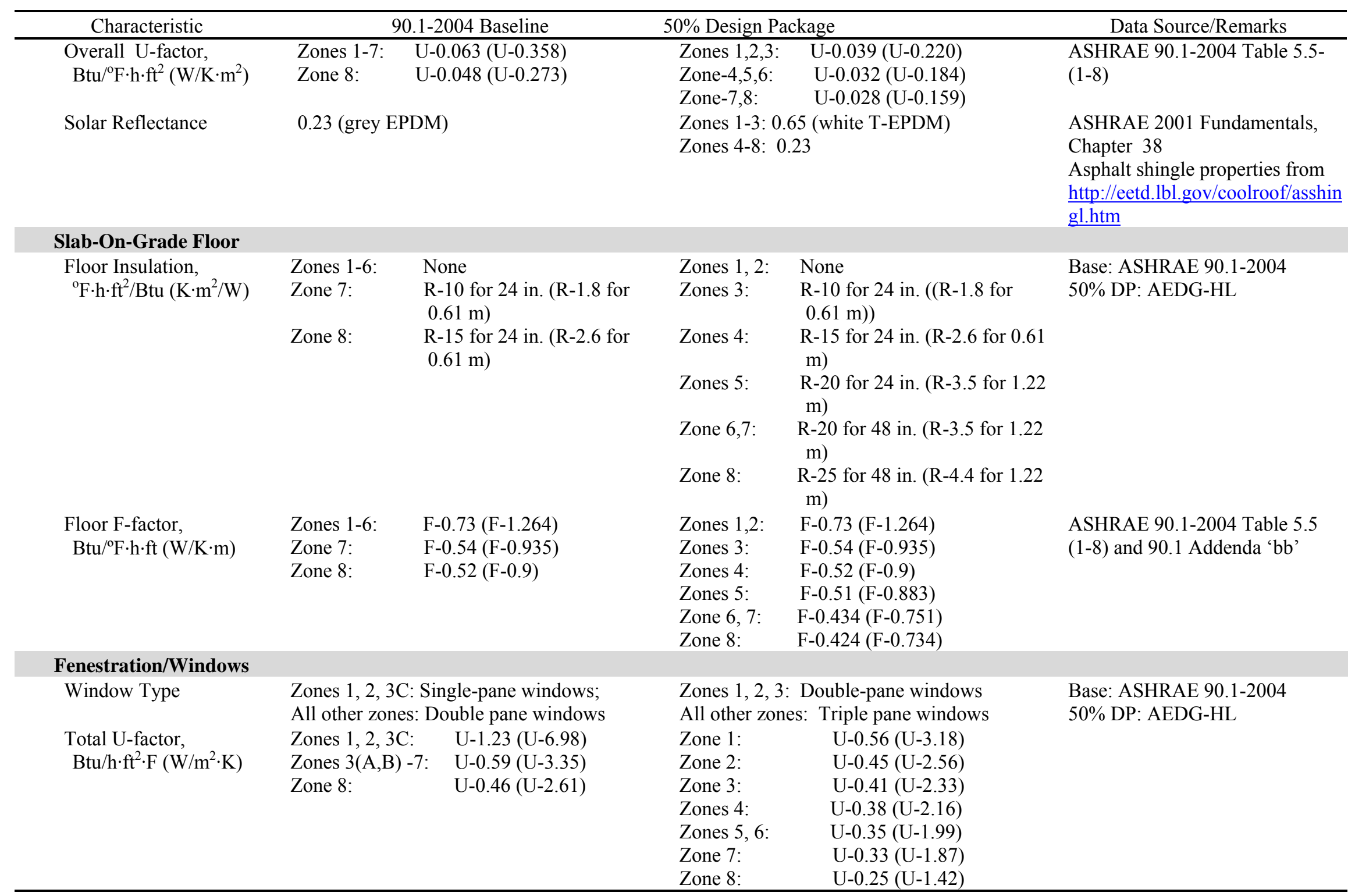




\begin{tabular}{|c|c|c|c|c|c|}
\hline Characteristic & \multicolumn{2}{|r|}{ 90.1-2004 Baseline } & \multicolumn{2}{|c|}{$50 \%$ Design Package } & \multirow[t]{2}{*}{ Data Source/Remarks } \\
\hline SHGC (Res/NonRes) & $\begin{array}{l}\text { Zones 1, 2: } \\
\text { Zone3: } \\
\text { Zone 3C: } \\
\text { Zones 4, 5, 6: } \\
\text { Zone 7: } \\
\text { Zone 8: }\end{array}$ & $\begin{array}{l}0.25 \\
0.39 / 0.25 \\
0.61 \\
0.39 \\
0.49 \\
\mathrm{NR}\end{array}$ & $\begin{array}{l}\text { Zone 1-3: } \\
\text { Zones 4,5: } \\
\text { Zone 6: } \\
\text { Zone 7,8: }\end{array}$ & $\begin{array}{c}0.25 \\
0.26 \\
0.35 \\
0.4\end{array}$ & \\
\hline $\begin{array}{l}\text { Actual Glazing Input, } \\
\mathrm{Btu} / \mathrm{h} \cdot \mathrm{ft}^{2} \cdot \mathrm{F}\left(\mathrm{W} / \mathrm{m}^{2} \cdot \mathrm{K}\right)\end{array}$ & $\begin{array}{l}\text { Zones 1, 2: } \\
\text { Zones 3A, 3B } \\
\text { Nonres : } \\
\text { Res : } \\
\text { Zones 3C } \\
\text { Nonres: } \\
\text { Res: } \\
\text { Zones 4, 5, 6: } \\
\text { Zone 7: } \\
\text { Zone 8: }\end{array}$ & $\begin{array}{l}\text { U-1.08 (U-6.13)/SHGC-0.28 } \\
\text { U-0.55 (U-3.12)/SHGC-0.43 } \\
\text { U-0.51 (U-2.90)/SHGC-0.28 } \\
\text { U-1.08 (U-6.13)/SHGC-0.61 } \\
\text { U-0.96 (U-5.45)/SHGC-0.37 } \\
\text { U-0.55 (U-3.12)/SHGC-0.43 } \\
\text { U-0.55 (U-3.12)/SHGC-0.50 } \\
\text { U-0.48 (U-2.73)/SHGC-0.47 }\end{array}$ & $\begin{array}{l}\text { Zone 1: } \\
\text { Zone 2,3: } \\
\text { Zone 4: } \\
\text { Zone 5: } \\
\text { Zone 6, 7: } \\
\text { Zone 8: }\end{array}$ & $\begin{array}{l}\mathrm{U}-0.51(\mathrm{U}-2.90) / \text { SHGC-0.28 } \\
\mathrm{U}-0.44(\mathrm{U}-2.50) / \text { SHGC-0.24 } \\
\mathrm{U}-0.40(\mathrm{U}-2.27) / \text { SHGC-0.24 } \\
\mathrm{U}-0.38(\mathrm{U}-2.16) / \text { SHGC-0.23 } \\
\mathrm{U}-0.31(\mathrm{U}-1.76) / \text { SHGC-0.38 } \\
\mathrm{U}-0.26(\mathrm{U}-1.48) / \text { SHGC-0.37 }\end{array}$ & $\begin{array}{l}\text { Window type chosen from } \\
\text { EnergyPlus Library with the } \\
\text { closest matching U-factor/SHGC }\end{array}$ \\
\hline \multicolumn{6}{|l|}{ INTERNAL LOADS } \\
\hline $\begin{array}{l}\text { Occupancy } \\
\text { Peak Number of People }\end{array}$ & $\begin{array}{l}\text { Guest Room: } 1 \\
\text { Lobby: } 53 \\
\text { Office: } 7 \\
\text { Laundry: } 11 \\
\text { Exercise Roon } \\
\text { Meeting Room } \\
\text { Corridor/Stairs }\end{array}$ & $\begin{array}{l}1.5 \\
\text { n: } 4 \\
\text { a: } 43 \\
\text { s/Storage: } 0\end{array}$ & Same & & $\begin{array}{l}2008 \text { Lodging Industry Profile } \\
\text { and AEDG-HL Committee } \\
\text { ASHRAE 62.1-2004 }\end{array}$ \\
\hline Occupancy Schedule & See under Sch & edules & Same & & AEDG-HL Committee's Inputs \\
\hline \multicolumn{6}{|l|}{ Lighting } \\
\hline $\begin{array}{l}\text { Peak Power Density, } \\
\mathrm{W} / \mathrm{ft}^{2}\left(\mathrm{~W} / \mathrm{m}^{2}\right)\end{array}$ & $\begin{array}{l}\text { Guest rooms: } \\
\text { Lobby: } 1.1(1 \\
\text { Corridors: } 0.5 \\
\text { Storage: } 0.8 \text { ( } \\
\text { Stairs: } 0.6(6 . \\
\text { Office: } 1.1(1 \\
\text { Laundry: } 0.6 \\
\text { Meeting Roor } \\
\text { Exercise Roo1 } \\
\text { Exterior: } 13.0\end{array}$ & $\begin{array}{l}1.1(11.84) \\
1.84) \\
5(5.38) \\
8.61) \\
46) \\
1.84) \\
(6.46) \\
\mathrm{m}: 1.3(14.00) \\
\mathrm{m}: 0.9 \text { (9.69) } \\
\mathrm{kW} \text { (Lighting Zone } 3)\end{array}$ & $\begin{array}{l}\text { Guest room } \\
\text { Lobby: } 0.7 \\
\text { Corridors: } \\
\text { Storage: } 0 . \\
\text { Stairs: } 0.57 \\
\text { Office: } 0.8 \\
\text { Laundry: } 0 \\
\text { Meeting Rc } \\
\text { Exercise Rc } \\
\text { Exterior: } 7\end{array}$ & $\begin{array}{l}71(7.64) \\
29) \\
5.38) \\
.67) \\
4) \\
15) \\
0.60) \\
1.14(12.27) \\
0.78(8.40) \\
V \text { (Lighting Zone 3) }\end{array}$ & $\begin{array}{l}\text { Base: ASHRAE 90.1-2004 } \\
\text { 50\%-DP: Lighting expert's inputs } \\
\text { (Exterior lighting } \\
\text { Base: ASHRAE 90.1-2004 } \\
\text { 50\%-DP: IESNA RP-33-99 and } \\
\text { lighting expert's inputs) }\end{array}$ \\
\hline
\end{tabular}




\begin{tabular}{|c|c|c|c|}
\hline Characteristic & 90.1-2004 Baseline & $50 \%$ Design Package & Data Source/Remarks \\
\hline Occupancy Sensors & Yes for meeting room and employee lounge & $\begin{array}{l}\text { Yes for Guest room, office, meeting room, } \\
\text { employee lounge, exercise room, laundry } \\
\text { room restroom, stairs, storage room, } \\
\text { mechanical \& electrical room }\end{array}$ & $\begin{array}{l}\text { Base: ASHRAE 90.1-2004 } \\
\text { 50\%-DP: AEDG-HL }\end{array}$ \\
\hline $\begin{array}{l}\text { Daylighting Responsive } \\
\text { Lighting Control }\end{array}$ & No & Same & AEDG-HL \\
\hline \multicolumn{4}{|l|}{ Plug Load } \\
\hline $\begin{array}{l}\text { Peak Power Density, } \\
\mathrm{W} / \mathrm{ft}^{2}\left(\mathrm{~W} / \mathrm{m}^{2}\right)\end{array}$ & $\begin{array}{l}\text { Guest rooms: } 1.01(10.82) \\
\text { Lobby: } 2.59(27.90) \\
\text { Corridors/Stairs/Storage: } 0.0(0.0) \\
\text { Office: } 1.24(13.37) \\
\text { Meeting Room: } 0.57(6.18) \\
\text { Exercise Room: } 1.77(19.05) \\
\text { Employee Lounge: } 2.0(21.51) \\
\text { Laundry: Dryer gas }-0.68 \text { therms } / \text { cycle } \\
\quad \text { (19.93 kWh } / \text { cycle) } \\
\text { Dryer Electric }-0.75 \mathrm{kWh} / \text { cycle } \\
\text { Washer: } 1.39 \mathrm{kWh} / \text { cycle }(85 \mathrm{G})\end{array}$ & $\begin{array}{l}\text { Guest rooms: } 0.97 \\
\text { Lobby: } 1.83 \\
\text { Corridors/Stairs/Storage: } 0.0 \\
\text { Office: } 0.63 \\
\text { Meeting Room: } 0.57 \\
\text { Exercise Room: } 1.53 \\
\text { Employee Lounge: } 1.95 \\
\text { Laundry: Dryer gas }-0.41 \text { therms } / \text { cycle } \\
\text { (12.03 } \mathrm{kWh} / \text { cycle) } \\
\text { Dryer Electric }-0.75 \mathrm{kWh} / \text { cycle } \\
\text { Washer: } 1.73 \mathrm{kWh} / \text { cycle }(354 \mathrm{G})\end{array}$ & $\begin{array}{l}\text { Engineering calculation } \\
\text { AEDG-HL Committee's inputs - } \\
60 \mathrm{lb}(27.2 \mathrm{~kg}) \text { washer and } 75 \mathrm{lb} \\
(34.0 \mathrm{~kg}) \text { dryer, assuming } 9 \mathrm{lb} \\
(4.1 \mathrm{~kg}) \text { of wash load per room }\end{array}$ \\
\hline \multicolumn{4}{|l|}{ Elevator } \\
\hline $\begin{array}{l}\text { Power Consumption } \\
(\mathrm{kWh} / \text { year })\end{array}$ & $3864 \mathrm{~W}$ & Same & Engineering calculation \\
\hline Equipment Schedule & See under Schedules & Same & AEDG-HL \\
\hline \multicolumn{4}{|l|}{ HVAC SYSTEM } \\
\hline \multicolumn{4}{|l|}{ System Type } \\
\hline Heating/ Cooling Type & $\begin{array}{l}\text { - Guest room: Package terminal air } \\
\text { conditioner (PTAC) with electric } \\
\text { resistance ( } 9 \mathrm{kBtu} / \mathrm{h}(2.6 \mathrm{~kW}) \text { capacity); } \\
\text { make-up air unit with DX cooling and } \\
\text { furnace (MAU) } \\
\text { - Public space: Split system with DX } \\
\text { cooling and furnace; unit heater for } \\
\text { mechanical room }\end{array}$ & $\begin{array}{l}\text { - Guest room: Water source heat pump (9 } \\
\text { kBtu/h }(2.6 \mathrm{~kW}) \text { capacity); MAU with } \\
\text { energy recovery } \\
\text { - Public space: Water source heat pump } \\
\text { system; unit heater for mechanical room }\end{array}$ & $\begin{array}{l}\text { Base: } 2003 \text { CBECS, NC } \text {, Ducker } \\
\text { Report }\end{array}$ \\
\hline \multicolumn{4}{|l|}{ HVAC Efficiency } \\
\hline Cooing Efficiency & $\begin{array}{l}\text { - PTAC: } \text { EER }=10.6 \\
\text { - } \text { Split system (normalized to 5-ton }(17.6 \\
\text { kW): SEER=10 } \\
\text { - MAU (normalized to 10-ton }(35.2 \mathrm{~kW}) \text { ): } \\
\text { EER=10.1 }\end{array}$ & 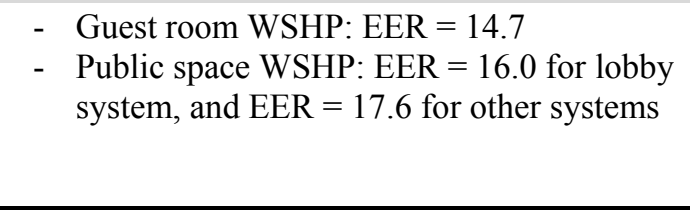 & $\begin{array}{l}\text { Base: ASHRAE } 90.1-2004 \\
50 \% \text { DP: AHRI certified } \\
\text { equipment database and CEC } \\
\text { appliances database }\end{array}$ \\
\hline
\end{tabular}




\begin{tabular}{|c|c|c|c|}
\hline Characteristic & 90.1-2004 Baseline & $50 \%$ Design Package & Data Source/Remarks \\
\hline Heating Efficiency & $\begin{array}{ll}\text { - } & \text { PTAC: } \mathrm{E}_{\mathrm{t}}=100 \% \\
\text { - } & \text { Split system (normalized to 5-ton }(17.6 \\
& \mathrm{kW}) \text { ): HSPF }=9.0 \\
\text { - } & \text { Et }=80 \% \\
\text { - } & \text { Unit heater: } \mathrm{Et}=80 \% \\
\text { - } & \text { MAU: } \mathrm{E}_{\mathrm{c}}=80 \%\end{array}$ & $\begin{array}{ll}\text { - } & \text { Guest room WSHP: COP }=5.2 \\
\text { - } & \text { Public space WSHP COP }=5.0 \text { for lobby } \\
& \text { system, and } 17.6 \text { for other systems } \\
\text { - } & \text { Unit heater: } \mathrm{E}_{\mathrm{t}}=80 \%\end{array}$ & $\begin{array}{l}\text { Base: ASHRAE 90.1-2004 } \\
\text { 50\% DP: AHRI certified } \\
\text { equipment database and CEC } \\
\text { appliances database }\end{array}$ \\
\hline \multicolumn{4}{|l|}{ HVAC Control } \\
\hline Cooling T-stat, ${ }^{\circ} \mathrm{F}\left({ }^{\circ} \mathrm{C}\right)$ & $\begin{array}{ll}\text { - } & \text { Rented guest room: } 70(21.1) \\
\text { - } & \text { Vacant guest room: } 74(23.3) \\
\text { - } & \text { All public space: } 75(23.9)\end{array}$ & 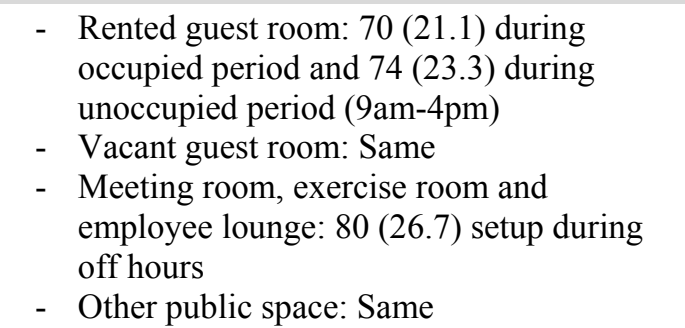 & $\begin{array}{l}\text { Base: General practice } \\
50 \% \text { DP: AEDG-HL and general } \\
\text { practice }\end{array}$ \\
\hline Heating T-stat, ${ }^{\circ} \mathrm{F}\left({ }^{\circ} \mathrm{C}\right)$ & $\begin{array}{l}\text { - } \quad \text { Occupied guest room: } 70(21.1) \\
\text { - } \quad \text { Vacant guest room: } 66(18.9) \\
\text { - } \quad \text { All public space: } 70(21.1)\end{array}$ & 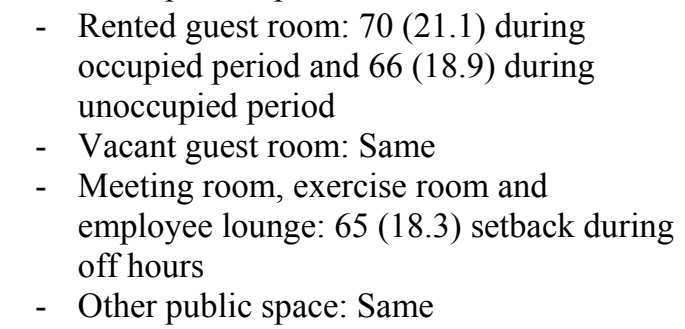 & $\begin{array}{l}\text { Base: General practice } \\
50 \% \text { DP: AEDG-HL and general } \\
\text { practice }\end{array}$ \\
\hline $\begin{array}{l}\text { Design Supply Air, cfm } \\
\left(\mathrm{m}^{3} / \mathrm{s}\right)\end{array}$ & $\begin{array}{l}\text { - PTAC: } 275(0.13) \\
\text { - } \quad \text { Split system: Autosized }\end{array}$ & - PTAC: $333(0.16)$ & PTAC Manufacturers' catalogs \\
\hline \multicolumn{4}{|l|}{ Ventilation } \\
\hline $\begin{array}{l}\text { Outdoor Air Supply, cfm } \\
\left(\mathrm{m}^{3} / \mathrm{s}\right)\end{array}$ & $\begin{array}{ll}\text { - } & \text { Guest room } / \text { Employee lounge } \\
& \text { Office } / \text { Meeting room : } 5 \mathrm{cfm} / \text { person }+ \\
& 0.06 \mathrm{cfm} / \mathrm{ft}^{2}\left(0.0024 \mathrm{~m}^{3} / \mathrm{s} / \text { person }+\right. \\
& \left.0.0003 \mathrm{~m}^{3} / \mathrm{s} / \mathrm{m}^{2}\right) \\
\text { - } & \text { Lobby: } 7.5 \mathrm{cfm} / \text { person }+0.06 \mathrm{cfm} / \mathrm{ft} 2 \\
& \left(0.0035 \mathrm{~m}^{3} / \mathrm{s} / \text { person }+0.0003 \mathrm{~m}^{3} / \mathrm{s} / \mathrm{m}^{2}\right) \\
\text { - } & \text { Exercise room: } 20 \mathrm{cfm} / \text { person }+0.06 \\
& \mathrm{cfm} / \mathrm{ft}^{2}\left(0.0094 \mathrm{~m}^{3} / \mathrm{s} / \text { person }+0.0003\right. \\
\left.\mathrm{m}^{3} / \mathrm{s} / \mathrm{m}^{2}\right) \\
\text { - }\end{array}$ & Same & ASHRAE 62.1-2004 \\
\hline
\end{tabular}




\begin{tabular}{|c|c|c|c|}
\hline Characteristic & 90.1-2004 Baseline & $50 \%$ Design Package & Data Source/Remarks \\
\hline $\begin{array}{l}\text { Guest Room Exhaust } \\
\text { Air, cfm }\left(\mathrm{m}^{3} / \mathrm{s}\right)\end{array}$ & $\begin{array}{l}5 \mathrm{cfm} / \text { person }+0.06 \mathrm{cfm} / \mathrm{ft}^{2}(0.0024 \\
\left.\mathrm{m}^{3} / \mathrm{s} / \text { person }+0.0003 \mathrm{~m}^{3} / \mathrm{s} / \mathrm{m}^{2}\right)\end{array}$ & Same & ASHRAE 62.1-2001 \\
\hline Ventilation Control & $\begin{array}{l}\text { Outside air damper remains open all the } \\
\text { time }\end{array}$ & $\begin{array}{l}\text { Outside air damper closed for vacant guest } \\
\text { rooms, meeting room, employee lounge and } \\
\text { exercise room during unoccupied period }\end{array}$ & ASHRAE Standard 90.1-2004 \\
\hline $\begin{array}{l}\text { Energy Recovery } \\
\text { Ventilator }\end{array}$ & None & Yes & $\begin{array}{l}\text { Base: ASHRAE Standard 90.1- } \\
2004 \\
50 \% \text { DP: AEDG-HL }\end{array}$ \\
\hline $\begin{array}{l}\text { Energy Recovery } \\
\text { Ventilation Sensible } \\
\text { Heat Efficiency }\end{array}$ & None & $\begin{array}{l}\text { Sensible: } 75 \% \\
\text { Latent: } 70 \%\end{array}$ & Manufactures' catalogs \\
\hline $\begin{array}{l}\text { Energy Recovery } \\
\text { Ventilation Auxiliary } \\
\text { Power, W }\end{array}$ & None & 200 & Manufactures' catalogs \\
\hline $\begin{array}{l}\text { Demanded Control } \\
\text { Ventilation }\end{array}$ & None & Same & \\
\hline Economizer & None & $\begin{array}{l}\text { Yes for system with size }>54,000 \mathrm{Btu} / \mathrm{h} \\
(15,822 \mathrm{~W}) \text { in Zone } 3 \sim 8\end{array}$ & $\begin{array}{l}\text { Base: ASHRAE Standard 90.1- } \\
2004 \\
50 \% \text { DP: AEDG-HL }\end{array}$ \\
\hline \multicolumn{4}{|l|}{ Fan Loads } \\
\hline Fan Efficiency & Vary based on motor power & Same & $\begin{array}{l}\text { Base: ASHRAE Standard 90.1- } \\
2004 \\
50 \% \text { DP: CEC premium motor } \\
\text { efficiency }\end{array}$ \\
\hline $\begin{array}{l}\text { Supply Fan Power/Static } \\
\text { Pressure, } \mathrm{W} / \mathrm{cfm} \text { or in. } \\
\text { w.c. }\left(\mathrm{W} / \mathrm{m}^{3} / \mathrm{s} \text { or } \mathrm{Pa}\right)\end{array}$ & $\begin{array}{l}\text { - PTAC: } 0.3 \mathrm{~W} / \mathrm{cfm}\left(634.6 \mathrm{~W} / \mathrm{m}^{3} / \mathrm{s}\right) \text { at } \\
\text { high speed; } 0.227 \mathrm{~W} / \mathrm{cfm}\left(480.2 \mathrm{~W} / \mathrm{m}^{3} / \mathrm{s}\right) \\
\text { at low speed } \\
\text { - } \text { Split system: } 1.75 \text { in. W.c. }(436 \mathrm{~Pa}) \\
\text { - } \text { MAU: } 1.55 \text { in. w.c. }(386 \mathrm{~Pa})\end{array}$ & $\begin{array}{l}\text { - Guest room WSHP: } 0.184 \mathrm{~W} / \mathrm{cfm}(389.2 \\
\left.\mathrm{W} / \mathrm{m}^{3} / \mathrm{s}\right) \text { at high speed; } 0.132 \mathrm{~W} / \mathrm{cfm} \\
\left(279.2 \mathrm{~W} / \mathrm{m}^{3} / \mathrm{s}\right) \text { at low speed } \\
\text { - Public spaces WSHP: } 1.48 \mathrm{in} \text {. w.c. }(369 \\
\text { Pa) plus } 0.75 \text { in. w.c. }(187 \mathrm{~Pa}) \text { with ERV } \\
\text { - MAU: } 1.23 \text { in. w.c. }(307 \mathrm{~Pa}) \text { plus } 0.75 \mathrm{in} . \\
\text { w.c. }(187 \mathrm{~Pa}) \text { with ERV }\end{array}$ & $\begin{array}{l}\text { PTAC/WSHP: Manufactures' } \\
\text { Catalogs } \\
\text { Engineering calculation }\end{array}$ \\
\hline
\end{tabular}




\begin{tabular}{|c|c|c|c|}
\hline Characteristic & 90.1-2004 Baseline & $50 \%$ Design Package & Data Source/Remarks \\
\hline Supply Fan Schedule & $\begin{array}{ll}\text { - } & \text { Rented guest room: Continuously at high } \\
\text { speed } \\
\text { - } \text { Vacant guest room: Continuously at high } \\
\text { speed } \\
\text { - Public space: Continuously }\end{array}$ & $\begin{array}{l}\text { - Rented guest room: Continuously at high } \\
\text { speed during occupied period, cycle on } \\
\text { and off during unoccupied period } \\
\text { - Vacant guest room: Cycle on and off } \\
\text { during unoccupied period } \\
\text { - } \text { Meeting room, employee lounge and } \\
\text { exercise room: Continuously at high speed } \\
\text { during occupied period, cycle on and off } \\
\text { during unoccupied period } \\
\text { - Other Public space: Continuously }\end{array}$ & $\begin{array}{l}\text { General practice } \\
\text { AEDG-HL }\end{array}$ \\
\hline $\begin{array}{l}\text { Exhaust Fan Static } \\
\text { Pressure, in. w.c. (Pa) }\end{array}$ & - $0.5(125)$ & Same & AEDG-HL \\
\hline Exhaust Fan Schedule & $\begin{array}{l}\text { - } \text { Rented guest room: Continuously } \\
\text { - Vacant guest room: Continuously } \\
\text { - } \quad \text { Public space: Continuously }\end{array}$ & Same & $\begin{array}{l}\text { General practice } \\
\text { AEDG-HL }\end{array}$ \\
\hline \multicolumn{4}{|l|}{ SERVICE WATER HEATING } \\
\hline \multicolumn{4}{|l|}{ Water Heater } \\
\hline Water Heater Type & Gas storage water heater & Same & AEDG-HL \\
\hline $\begin{array}{l}\text { Tank Capacity, gallon } \\
\text { (L) }\end{array}$ & $300(1,136)$ & Same & $\begin{array}{l}\text { ASHRAE Handbook Application } \\
2007 \text { Chapter } 49\end{array}$ \\
\hline $\begin{array}{l}\text { Hot Water Temperature, } \\
{ }^{\circ} \mathrm{F}\left({ }^{\circ} \mathrm{C}\right)\end{array}$ & $\begin{array}{l}\text { Guest room: } 120(48.9) \\
\text { Laundry: } 140(60.0)\end{array}$ & Same & General design practice \\
\hline Thermal Efficiency & $\mathrm{Et}=80 \%$ & $\mathrm{Et}=95 \%$ & $\begin{array}{l}\text { Base: ASHRAE 90.1-2004 Table } \\
7.2 .2 \\
50 \% \text { DP: ENERGY STAR } \\
\text { products }\end{array}$ \\
\hline $\begin{array}{l}\text { Tank UA, Btu }{ }^{\circ} \mathrm{F} \cdot \mathrm{h} \\
(\mathrm{W} / \mathrm{K})\end{array}$ & $15.414(8.13)$ & $15.414(8.13)$ & AEDG-SO TSD \\
\hline $\begin{array}{l}\text { Hot Water Demand, } \\
\text { gallon/day-room (L/day- } \\
\text { room) }\end{array}$ & $\begin{array}{l}\text { Guest room: } 14(53.0) \\
\text { Laundry: } 10.8(40.9)\end{array}$ & $\begin{array}{l}\text { Guest room: } 11.2(42.4) \\
\text { Laundry: } 4.0(15.1)\end{array}$ & $\begin{array}{ll}\text { - } & \text { Guest room: ASHRAE } \\
& \text { Handbook Application } 2007 \\
& \text { Chapter 49, Table } 7 \\
\text { - } & \text { Laundry: AEDG-HL }\end{array}$ \\
\hline $\begin{array}{l}\text { Drain Water heat } \\
\text { Recovery }\end{array}$ & No & Yes & AEDG-HL \\
\hline
\end{tabular}




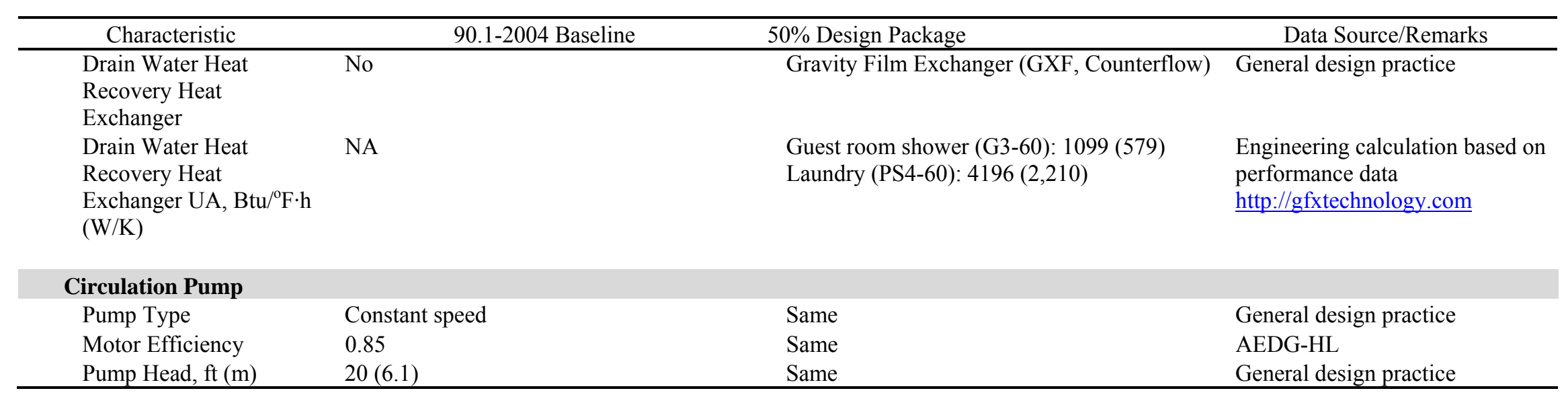


Appendix D

EnergyPlus Water-to-Air Cooling Coil and Heating Coil Performance Model Parameters 
Table D.1. Water-to-Air Cooling Coil Model for Guest Room

Number of Dataset

774

RatedAirVolFlowRate (m3/s)

$1.42 \mathrm{E}-01$

RatedWaterVolFlowRate $(\mathrm{m} 3 / \mathrm{s})$

$1.73 \mathrm{E}-04$

RatedTotalCap (W)

2724.88

RatedSensCap (W)

1907.41

RatedPower (W)

607.84

TotalCoolCapCoeff SensCoolCapCoeff CoolPowerCoeff

Coefficient 1

$-3.25950159$

3.33817187

$-5.64045868$

Coefficient 2

7.71579507

23.25683460

0.73063354

Coefficient 3

$-3.67661111$

$-24.89824486$

5.60233266

Coefficient 4

0.12026194

$-1.66288348$

0.16868244

Coefficient 5

0.129537638

0.501002517

0.056511969

$-0.184356758$

Coefficient 6

Error Analysis

Error

Total Capacity RMS error

0.04044

Sensible Capacity RMS error

0.06643

Heat Rejection RMS error

0.03128

Power RMS error

0.00756

Total Capacity RMS error (\%)

1.43642

Sensible Capacity RMS error (\%)

4.08421

Heat Rejection RMS error (\%)

0.88991

Power RMS error (\%)

1.21100

Total Capacity Average error (\%)

1.14076

Sensible Capacity Average error (\%)

3.19678

Heat Rejection Average error (\%)

0.72087

Power Average error (\%)

0.93508 
Table D.2. Water-to-Air Heating Coil Model for Guest Room

Number of Dataset

645

RatedAirVolFlowRate (m3/s) $\quad 0.1415842350$

RatedWaterVolFlowRate (m3/s) $\quad 0.0001734980$

RatedTotalCap (W) $\quad 3252.27$

RatedPower (W)

677.56

\section{TotalHeatCapCoeff HeatPowerCoeff}

\begin{tabular}{lcc} 
Coefficient 1 & -2.93612052 & -5.41372740 \\
Coefficient 2 & -1.22393899 & 5.37842685 \\
Coefficient 3 & 4.85695887 & 1.06113569 \\
Coefficient 4 & 0.100631538 & -0.210277288 \\
Coefficient 5 & 0.130139248 & 0.021401559 \\
\hline
\end{tabular}

Error Analysis Error

Heating Capacity RMS error $\quad 0.02$

Heat Absorption RMS error $\quad 0.03$

Power RMS error $\quad 0.01$

Heating Capacity RMS error (\%) $\quad 0.58$

Heat Absorption RMS error (\%) $\quad 1.15$

Power RMS error (\%) $\quad 1.49$

Heating Capacity average error (\%) $\quad 0.49$

Heat Absorption average error (\%) 0.94

Power average error $(\%) \quad 1.18$ 
Table D.3. Water-to-Air Cooling Coil Model for Lobby

Number of Dataset

RatedAirVolFlowRate (m3/s)

RatedWaterVolFlowRate (m3/s)

RatedTotalCap (W)

RatedSensCap (W)

RatedPower (W)
616

0.94389490

0.00113562

20627.01

14954.59

4400.00

\section{TotalCoolCapCoeff SensCoolCapCoeff CoolPowerCoeff}

\begin{tabular}{lccc} 
Coefficient 1 & -6.09338863 & 1.05772484 & -11.11804309 \\
Coefficient 2 & 9.07545771 & 23.32179099 & 6.95336117 \\
Coefficient 3 & -2.31139377 & -23.23325083 & 4.50123284 \\
Coefficient 4 & 0.12664765 & -1.26622445 & 0.26961825 \\
Coefficient 5 & 0.060528467 & 0.433721126 & -0.131890476 \\
Coefficient 6 & & 0.06298696 & \\
\hline
\end{tabular}

Error Analysis $\quad$ Error

Total Capacity RMS error $\quad 0.51166$

Sensible Capacity RMS error $\quad 0.79582$

Heat Rejection RMS error $\quad 2.20006$

Power RMS error $\quad 0.10510$

Total Capacity RMS error (\%) 2.37642

Sensible Capacity RMS error (\%) $\quad 6.35624$

Heat Rejection RMS error (\%) 8.85395

Power RMS error (\%) 3.01853

Total Capacity Average error (\%) 2.00645

Sensible Capacity Average error (\%) $\quad 5.27291$

Heat Rejection Average error (\%) $\quad 7.45183$

Power Average error (\%) 2.02326 
Table D.4. Water-to-Air Heating Coil Model for Lobby

Number of Dataset

RatedAirVolFlowRate (m3/s)

RatedWaterVolFlowRate (m3/s)

RatedTotalCap (W)

RatedPower (W)

Coefficient 1

Coefficient 2

Coefficient 3

Coefficient 4

Coefficient 5
645

1.03828439

0.00113562

24699.68

4939.94

TotalHeatCapCoeff HeatPowerCoeff

Error Analysis $\quad$ Error

Heating Capacity RMS error $\quad 0.33$

Heat Absorption RMS error $\quad 0.38$

Power RMS error $\quad 0.07$

Heating Capacity RMS error (\%) $\quad 1.33$

Heat Absorption RMS error (\%) $\quad 1.92$

Power RMS error (\%) 1.58

Heating Capacity average error (\%) $\quad 1.08$

Heat Absorption average error (\%) $\quad 1.56$

Power average error $(\%) \quad 1.24$ 
Table D.5. Water-to-Air Cooling Coil Model for Other Public Spaces

Number of Dataset

RatedAirVolFlowRate (m3/s)

RatedWaterVolFlowRate (m3/s)

RatedTotalCap (W)

RatedSensCap (W)

RatedPower (W)
773

$5.90 \mathrm{E}-01$

$5.68 \mathrm{E}-04$

9698.21

7273.66

1880.68

TotalCoolCapCoeff SensCoolCapCoeff CoolPowerCoeff

\begin{tabular}{lccc} 
Coefficient 1 & -3.76046593 & 3.52526051 & -5.35842774 \\
Coefficient 2 & 7.71812764 & 23.40882245 & 0.71146588 \\
Coefficient 3 & -3.19249143 & -25.05937731 & 5.34613606 \\
Coefficient 4 & 0.12060733 & -1.83410122 & 0.16504249 \\
Coefficient 5 & 0.111124733 & 0.504417741 & -0.196298243 \\
Coefficient 6 & & 0.061416461 & \\
\hline
\end{tabular}

Error Analysis $\quad$ Error

Total Capacity RMS error $\quad 0.14682$

Sensible Capacity RMS error $\quad 0.26336$

Heat Rejection RMS error $\quad 0.11401$

Power RMS error $\quad 0.02958$

Total Capacity RMS error (\%) $\quad 1.43165$

Sensible Capacity RMS error (\%) $\quad 4.21310$

Heat Rejection RMS error (\%) 0.93431

Power RMS error (\%) 1.51028

Total Capacity Average error (\%) $\quad 1.15224$

Sensible Capacity Average error (\%) $\quad 3.31122$

Heat Rejection Average error (\%) 0.75424

Power Average error (\%) $\quad 1.15619$ 
Table D.6. Water-to-Air Heating Coil Model for Other Public Spaces

Number of Dataset

RatedAirVolFlowRate (m3/s)

RatedWaterVolFlowRate (m3/s)

RatedTotalCap (W)

RatedPower (W)
645

$5.90 \mathrm{E}-01$

$5.68 \mathrm{E}-04$

11573.40

1995.41

TotalHeatCapCoeff HeatPowerCoeff

\begin{tabular}{lcc} 
Coefficient 1 & -3.32559850 & -6.05383019 \\
Coefficient 2 & -1.22860530 & 5.51862063 \\
Coefficient 3 & 5.21179208 & 1.54421134 \\
Coefficient 4 & 0.101015177 & -0.215758334 \\
Coefficient 5 & 0.000164806 & $4.81689 \mathrm{E}-05$ \\
\hline
\end{tabular}

Error Analysis Error

Heating Capacity RMS error $\quad 0.09$

Heat Absorption RMS error $\quad 0.16$

Power RMS error $\quad 0.03$

Heating Capacity RMS error (\%) $\quad 0.67$

Heat Absorption RMS error (\%) $\quad 1.39$

Power RMS error (\%) 1.48 


\section{Distribution}

No. of

Copies

\# Name

Organization

Address

City, State and ZIP Code

\# Organization

Address

City, State and ZIP Code

Name

Name

Name

Name

Name (\#)

\# Name

Organization

Address

City, State and ZIP Code
No. of

\section{Copies}

\# Foreign Distribution

\# Name

Organization

Address

Address line 2

COUNTRY

\# Local Distribution

Pacific Northwest National Laboratory

Name

Name

Name

Name

Name
Mailstop

Mailstop

Mailstop

Mailstop

(PDF) 



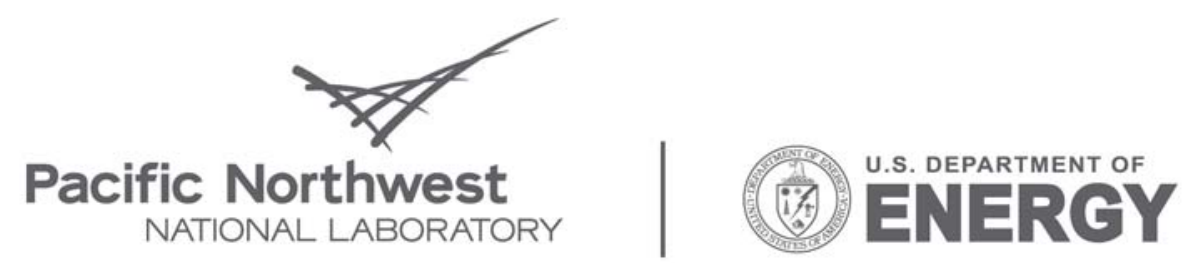

Proudly Operated by Battelle Since 1965

902 Battelle Boulevard

P.O. Box 999

Richland, WA 99352

1-888-375-PNNL (7665)

www.pnl.gov 